\title{
ABUSO DE POSIÇÃO DOMINANTE: CONDUTAS DE EXCLUSÃO EM RELAÇÕES DE DISTRIBUIÇÃO
}

Tese de Doutorado apresentada ao

Departamento de Direito Comercial

\section{Orientadora: Profa. Titular Paula Andrea Forgioni}

Universidade de São Paulo

Faculdade de Direito

São Paulo

2012 
Para Joaquim. 


\section{RESUMO}

O objetivo do trabalho é estudar as situações em que práticas de distribuição tendentes à exclusão podem configurar ilícitos de abuso de posição dominante por parte de fornecedores de bens e serviços.

Fornecedores de bens e serviços precisam identificar qual a forma mais eficiente de fazer que seus produtos cheguem até o consumidor final. Em determinadas circunstâncias, contudo, um fornecedor pode ocupar uma posição de domínio em determinados mercados e suas práticas de distribuição podem ter potenciais efeitos de exclusão, possivelmente causando efeitos indesejáveis sobre a concorrência.

Ao longo do trabalho, buscamos contextualizar e compreender a ideia de exclusão, com recurso à análise do tratamento dado às condutas de exclusão por parte do direito antitruste dos Estados Unidos, do direito da concorrência comunitário europeu e do direito da concorrência brasileiro. Buscamos, ainda, traçar um panorama das principais linhas da teoria econômica que oferecem subsídios à compreensão da ideia de exclusão, bem como as contribuições específicas com referência ao tema. Examinamos, também, as principais práticas de distribuição tendentes à exclusão, que classificamos em tradicionais e não tradicionais, buscando compreender seus efeitos e motivações.

Ao final, apresenta-se um diagnóstico e a conclusão. O tratamento das práticas de distribuição tendentes à exclusão deve encontrar um equilíbrio entre, de um lado, a repressão adequada dos abusos de posição dominante envolvendo relações de distribuição e, de outro, a preservação do incentivo para que fornecedores adotem formas eficientes, inovadoras e concorrenciais de estruturar seus sistemas de distribuição. 


\begin{abstract}
The work seeks to examine situations in which distribution practices tending towards exclusion may characterize illicit acts of abuse of a dominant position by suppliers of goods and services.

Suppliers of goods and services need to identify the most efficient way of getting their products to the end user. In certain circumstances, though, a supplier may occupy a dominant position in given markets, and its distribution practices may have effects of exclusion, possibly affecting competition unfavorably.

Throughout the work, we attempt to contextualize and understand the idea of exclusion, using an analysis of the treatment given to exclusionary conducts under United States antitrust law, the competition law of the European community and Brazilian competition law. We also seek to sketch out an overview of the main lines of economic theory that assist in an understanding of the idea of exclusion, along with specific contributions making reference to the issue. We also examine the main distribution practices tending towards exclusion, which we classify into traditional and non-traditional, seeking to understand their effects and rationale.

Lastly, a diagnosis and conclusion are presented. The treatment of distribution practices with a trend towards exclusion must strike a balance between, on the one hand, proper repression of abuses of a dominant position involving distribution relations and, on the other, the preservation of an incentive for suppliers to adopt efficient, innovative and competitive ways of structuring their distribution systems.
\end{abstract}




\section{RÉSUMÉ}

L'objet du travail, c'est étudier les situations où des pratiques de distribution avec tendance à l'exclusion peuvent configurer comme illicites d'abus de position dominante de la part de fournisseurs de biens et de services.

Fournisseurs de biens et de services ont besoin d'identifier quelle est la forme plus efficace de faire que leurs produits arrivent jusqu'au consommateur final. À des certaines circonstances, pourtant, un fournisseur peut occuper une position de domaine à des certains marchés et leurs pratiques de distribution peuvent avoir des effets d'exclusion potentiels, possiblement en provoquant des effets indésirables sur la concurrence.

Pendant le travail, nous avons essayé de contextualiser et de comprendre l'idée d'exclusion, avec recours à l'analyse du traitement donné aux conduites d'exclusion de la part du droit antitrust des Etats-Unis, du droit de concurrence communautaire européen et du droit de concurrence brésilien. Nous avons encore essayer de tracer un panorama des principales lignes de la théorie économique qui offrent des subsides à la compréhension de l'idée d'exclusion, aussi comme les contributions spécifiques concernant le thème. Nous avons aussi examiné les principales pratiques de distribution qui ont une tendance à l'exclusion, qui nous avons classifié en traditionnelles et non traditionnelles, en essayant de comprendre leurs effets et leurs motivations .

Enfin, on présente un diagnostic et la conclusion. Le traitement des pratiques de distribution qui ont une tendance doit trouver un équilibre entre, d'un côté, la répression adéquate des abus de position dominante concernant des rapports de distribution et, d'autre côté, la préservation de l'encouragement pour que des fournisseurs adoptent des formes efficaces, innovatrices et concurrentielles de structurer ses systèmes de distribution. 


\section{CAPÍTULO I - DIREITO DA CONCORRÊNCIA: ORIGENS, CONCEPÇÕES E VALORES

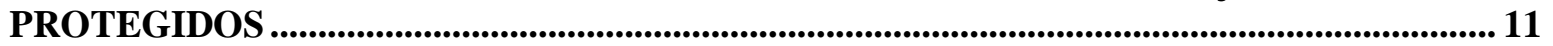

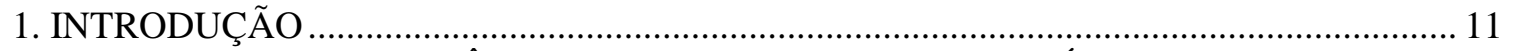 \\ 2. DIREITO DA CONCORRÊNCIA NO BRASIL: ORIGEM HISTÓRICA E BASE}

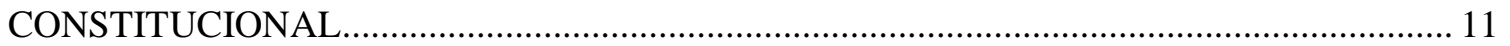

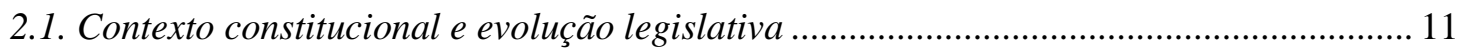

2.2. A Constituição Federal de 1988, a Lei 8.884/94 e a Lei 12.529/2011 .............................. 14

2.3. Principais mudanças trazidas pela Lei 12.529/2011 .................................................... 16

3. CONCEPÇÕES E ENFOQUES DA DISCIPLINA DA CONCORRÊNCIA NO BRASIL .... 19

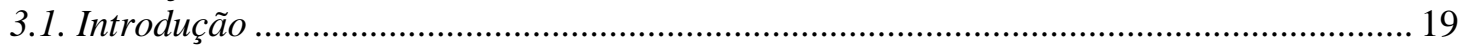

3.2. Diferentes enfoques da disciplina da concorrência: panorama ...................................... 19

3.3. O direito da concorrência como instrumento de implementação de políticas públicas.... 21

3.4. Disciplina da concorrência e mercado: a relação da disciplina da concorrência com o

direito comercial: direito da concorrência como microssistema ............................................. 22

3.5. Direito da concorrência e os direitos ou interesses coletivos ............................................. 27

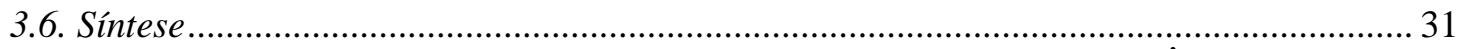

4. VALORES PROTEGIDOS E OBJETIVOS DO DIREITO DA CONCORRÊNCIA............... 32

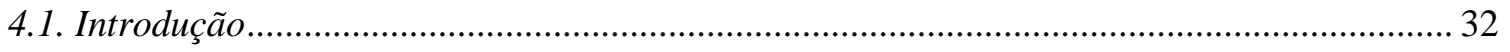

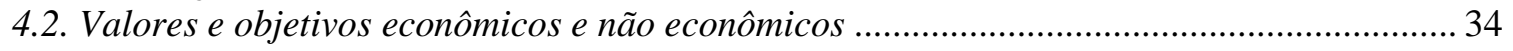

4.3. Valores e objetivos podem ser deduzidos a partir das origens históricas da disciplina

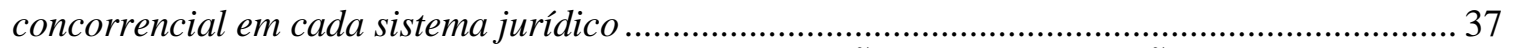

5. ELEMENTOS QUE INFLUENCIAM A APLICAÇÃO E A FORMAÇÃO DO DIREITO DA

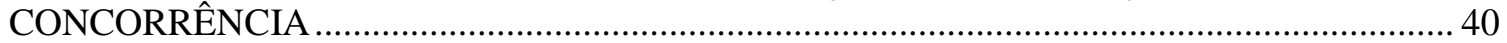

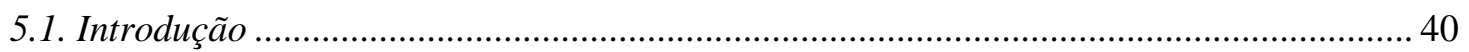

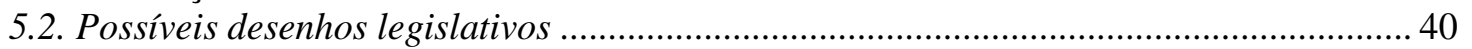

5.3. Decisões políticas, decisões econômicas e desenho institucional ....................................... 43

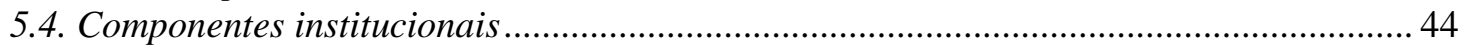

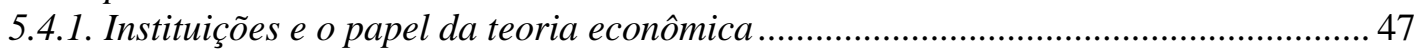


CAPÍTULO II - DIREITO DA CONCORRÊNCIA, ABUSO DE POSIÇÃO DOMINANTE E

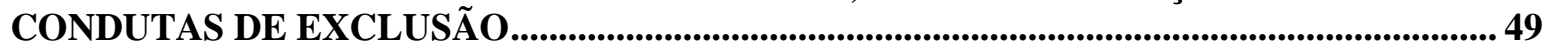

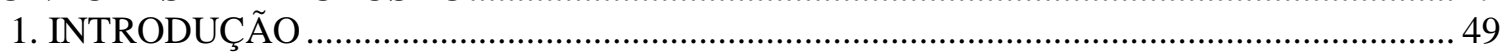

2. PODER ECONÔMICO, PODER DE MERCADO E POSIÇÃO DOMINANTE ................... 53

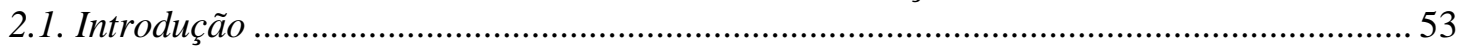

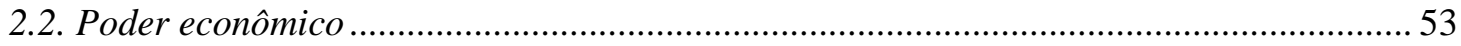

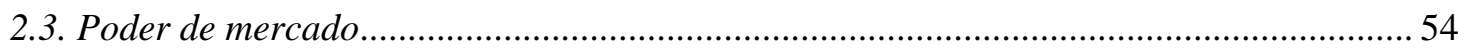

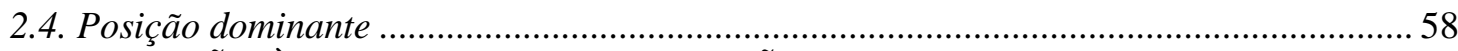

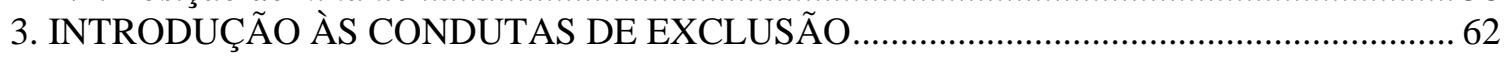

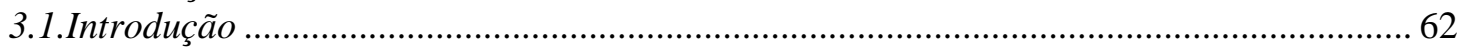

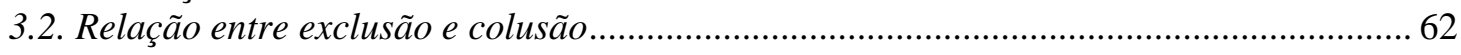

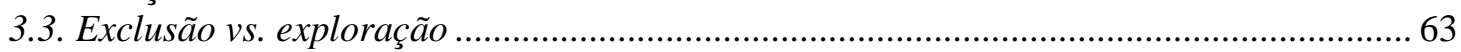

3.4. Abusos de exclusão multilaterais ou coordenados vs. abusos unilaterais de exclusão..... 66 4. PANORAMA DA DISCIPLINA DE REPRESSÃO AO ABUSO DE POSIÇÃO

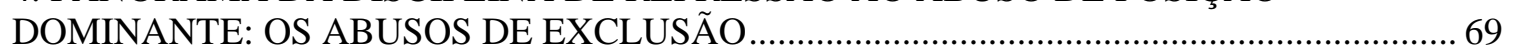

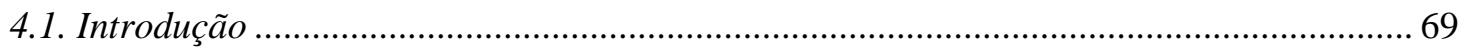

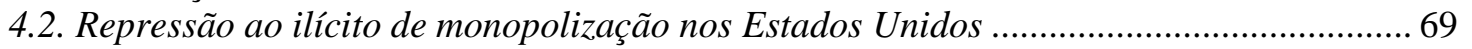

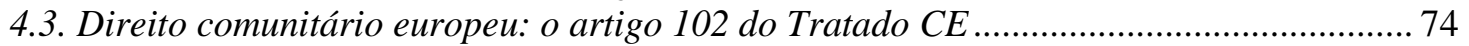

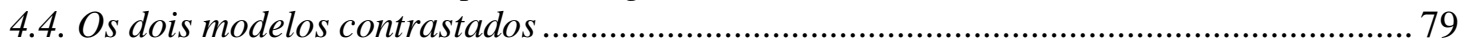

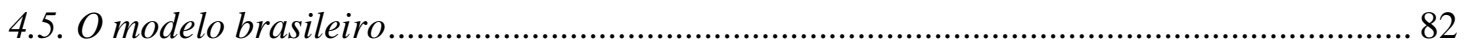

5. PANORAMA DAS DIFICULDADES NO TRATAMENTO DAS CONDUTAS DE

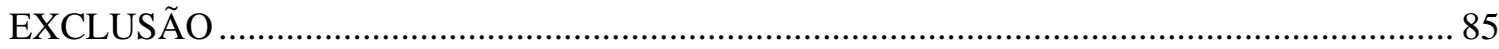

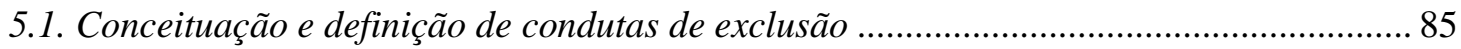

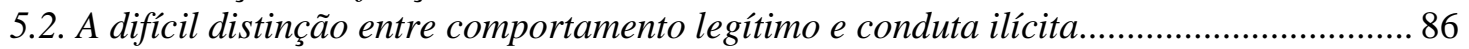

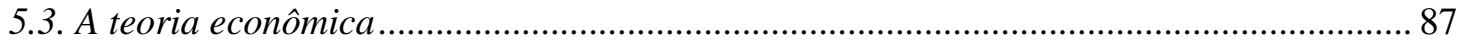

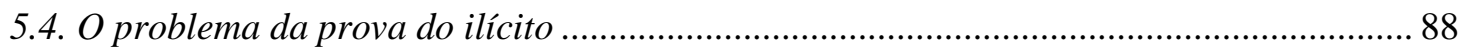

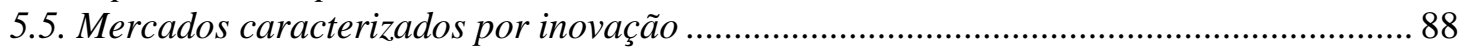

CAPÍTULO III - EXCLUSÃO E TEORIA ECONÔMICA............................................................. 90

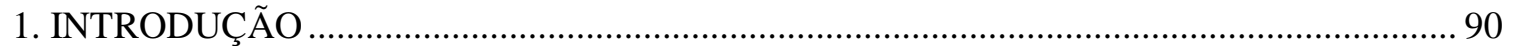

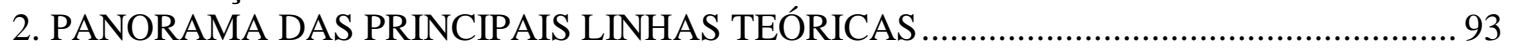

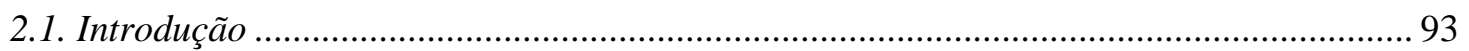

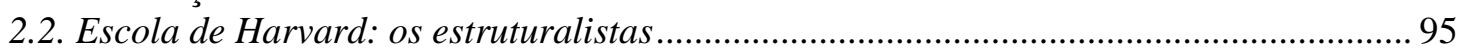

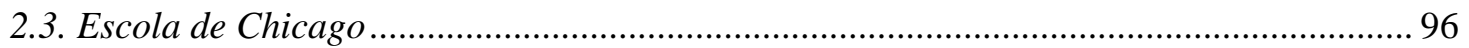

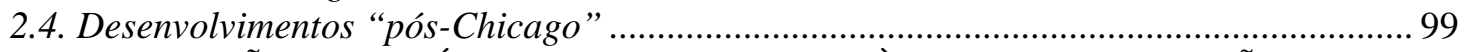

3. CONTRIBUIÇÕES ESPECÍFICAS RELACIONADAS À IDEIA DE EXCLUSÃO........... 101

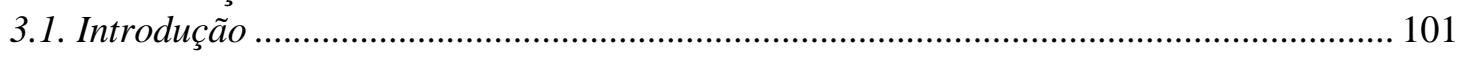

3.2. A exclusão e a teoria da alavancagem (leverage doctrine): impactos para os acordos de

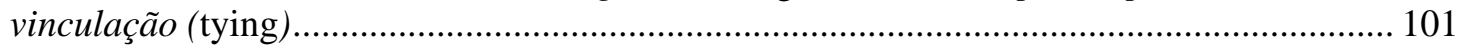

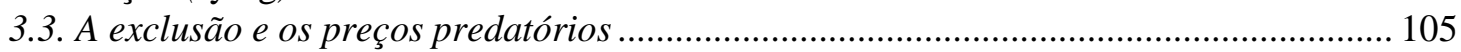

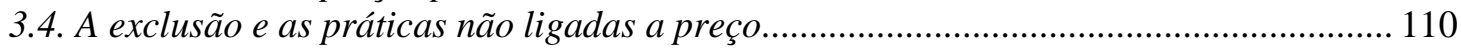

3.4.1. Exclusividade, recusa unilateral de contratar e a Escola de Chicago ...................... 110

3.4.2. A exclusão e a teoria de aumento dos custos dos rivais (raising rivals costs) .......... 113

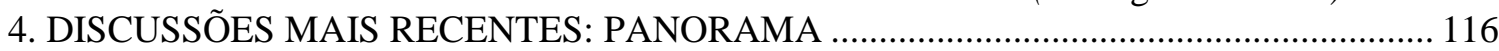

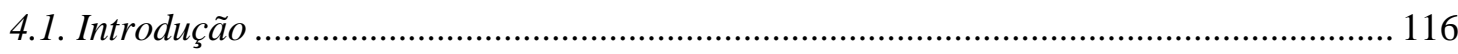

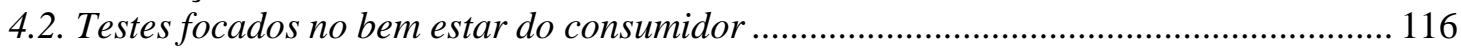

4.3. Testes focados nas perdas sofridas pelos agentes econômicos dominantes e na

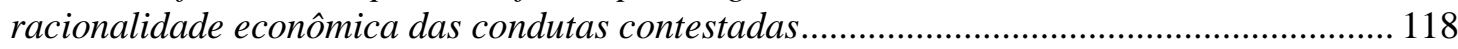

4.4. Testes com referência à eficiência de rivais.................................................................... 120 
CAPÍTULO IV - ABUSO DE POSIÇÃO DOMINANTE E ESTRATÉGIAS DE

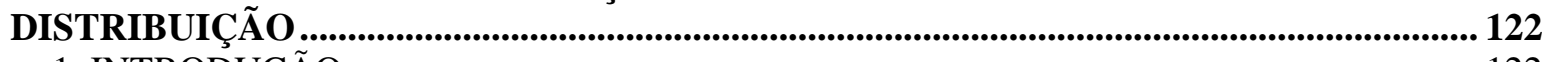

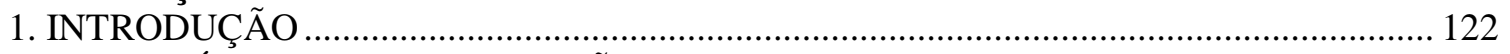

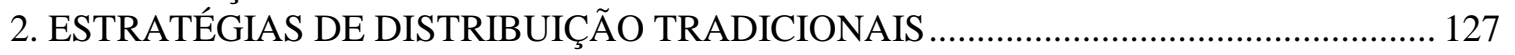

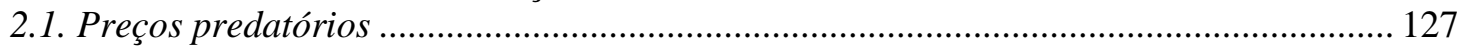

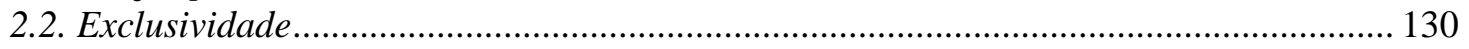

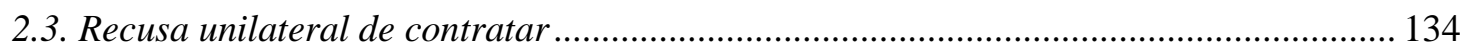

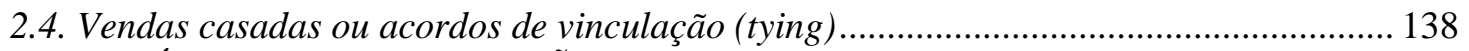

3. ESTRATÉGIAS DE DISTRIBUIÇÃO MENOS TRADICIONAIS ................................... 142

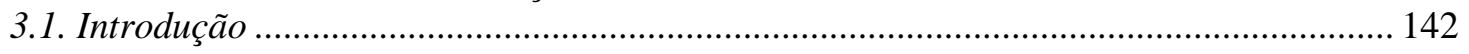

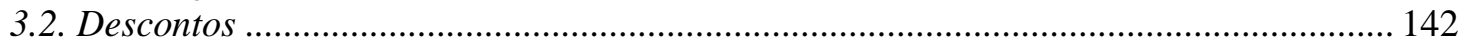

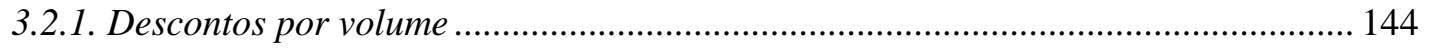

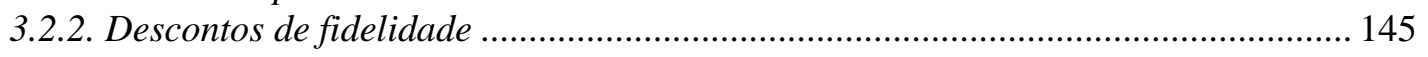

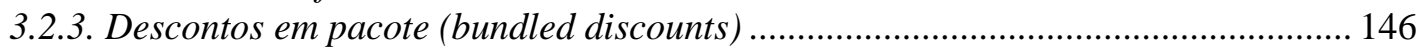

3.2.3.1. Descontos em pacote como prática predatória ou como forma de venda casada

3.3. Outras estratégias de distribuição não tradicionais ...................................................... 153

3.4. Jurisprudência administrativa brasileira relativa a práticas de distribuição menos

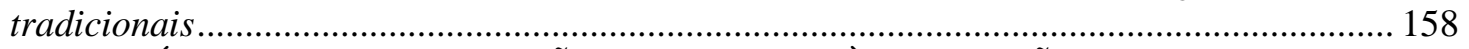

4. ESTRATÉGIAS DE DISTRIBUIÇÃO TENTENDES À EXCLUSÃO E O DIREITO

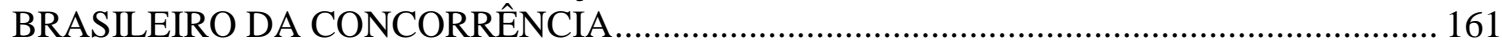

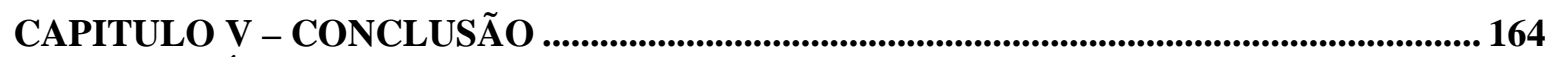

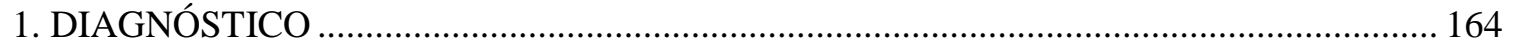

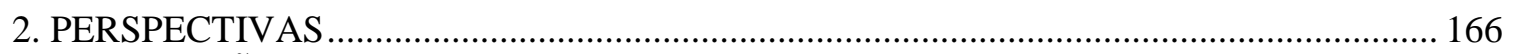

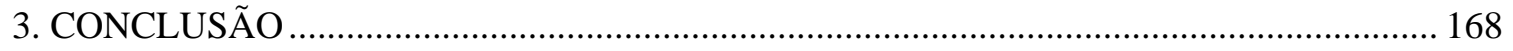

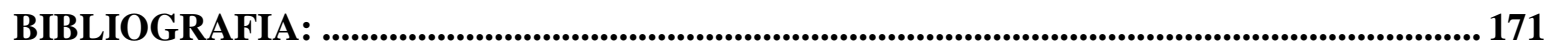




\section{INTRODUÇÃO}

Em $1^{\circ}$ de dezembro de 2011, foi publicada no Diário Oficial da União a Lei 12.529, de 30 de novembro de 2011, que versa sobre a disciplina da concorrência no Brasil. Conforme artigo 128, a Lei 12.529/2011 entrará em vigor após decorridos 180 (cento e oitenta) dias contados da data da sua publicação oficial e, portanto, entrará em vigor em maio de 2012.

Em seu artigo $1^{\circ}$, a Lei 12.529/2011 estabelece o seu objeto: "a prevenção e a repressão às infrações contra a ordem econômica, orientada pelos ditames constitucionais de liberdade de iniciativa, livre concorrência, função social da propriedade, defesa dos consumidores e repressão ao abuso do poder econômico." O artigo $1^{\circ}$ da Lei 12.529/2011 é idêntico ao artigo $1^{\circ}$ da Lei 8.884/94, atualmente em vigor.

Como se sabe, há normas que regulam a disciplina da concorrência no Brasil desde 1938, quando da edição do Decreto-lei 869/1938, considerado por SCHIEBER como a "primeira norma jurídica antitruste brasileira". ${ }^{1}$ É razoável afirmar, no entanto, que foi somente a partir da edição da Lei 8.884/94 que as normas de disciplina da concorrência passaram a ser aplicadas de forma mais efetiva no Brasil. ${ }^{2}$

A aplicação mais efetiva de normas concorrenciais no Brasil, a partir da edição da Lei 8.884/94, pode ser explicada por uma série de fatores.

Como primeiro fator, observa-se o desenho institucional adotado pela Lei 8.884/94: a lei transformou o Conselho Administrativo de Defesa Econômica (CADE) em autarquia federal, com destinação orçamentária própria, visando a conferir ao órgão decisório um maior grau de independência. Também na linha de independência do CADE, a lei

\footnotetext{
${ }^{1}$ SHIEBER, Benjamim. Abusos do Poder Econômico. Direito e Experiência Antitruste no Brasil e nos E.U.A. São Paulo: Editora Revista dos Tribunais, 1966, p. 4. SCHUARTZ aponta, no entanto, que a primeira lei de defesa da concorrência em sentido próprio seria, na verdade, a Lei 4.137/1962. SCHUARTZ, Luis Fernando. Desconstitucionalização do Direito da Concorrência.In:Revista do IBRAC, São Paulo, v. 16, n. 1, 2009, p. 332. ${ }^{2}$ Neste sentido, afirma SCHUARTZ: "A Lei 8.158/91 foi uma lei de transição. Ela serviu para colocar na pista certa a política de defesa da concorrência no País. Mas a decolagem só veio com a lei vigente, a Lei 8.884/94, e um conjunto de sinais mais explícitos e unívocos por parte do governo no sentido da relevância desta política e do apoio aos sujeitos encarregados de executá-la." SCHUARTZ, Luis Fernando. Desconstitucionalização do Direito da Concorrência. In: Revista do IBRAC, São Paulo, v. 16, n. 1, 2009, p. 332.
} 
estabeleceu que suas decisões não comportariam revisão no âmbito do Poder Executivo, formalmente fortalecendo a independência política do órgão. ${ }^{3}$

Além disso, transformações no cenário econômico nacional, com a abertura da economia brasileira, também colaboraram para um contexto em que a disciplina da concorrência passou a ter maior potencialidade de aplicação.

Aos poucos, ainda, como consequência e, às vezes, causa da maior implementação da lei, houve uma evolução institucional das autoridades administrativas responsáveis pela aplicação da lei de defesa da concorrência. A partir de casos concretos e, por vezes, de definição de prioridades, as autoridades de defesa da concorrência foram desenvolvendo e aperfeiçoando suas vocações e se afirmando não só como atores relevantes na formação e na criação do direito da concorrência, mas também no estabelecimento de tendências às formas de aplicação das normas.

Apesar do tom aparentemente otimista quanto ao maior grau de implementação das normas concorrenciais, parece-nos que, no Brasil, ainda não se tem a correta dimensão do papel do direito da concorrência de forma mais abrangente. Durante os mais de 15 (quinze) anos de vigência da Lei 8.884/94, diversos aspectos das normas de disciplina da concorrência permaneceram e permanecem indefinidos. Até o momento, questões concorrenciais ainda são primordialmente discutidas no âmbito do Sistema Brasileiro de Defesa da Concorrência (SBDC), ou seja, em sede de procedimentos administrativos, envolvendo investigações de condutas anticompetitivas ou atos de concentração. As discussões judiciais acerca de questões concorrenciais ainda são pouco frequentes, estando limitadas principalmente a questionamentos sobre as decisões proferidas pelos órgãos administrativos ${ }^{4}$, discussões incidentais sobre a legalidade de determinadas condutas ou cláusulas contratuais e, em menor grau, a ações buscando a reparação de danos por ilícitos

\footnotetext{
${ }^{3}$ Artigo 50: "As decisões do CADE não comportam revisão no âmbito do Poder Executivo, promovendo-se, de imediato, sua execução e comunicando-se, em seguida, ao Ministério Público, para as demais medidas legais cabíveis no âmbito de suas atribuições."

${ }^{4}$ Para uma visão completa acerca das decisões judiciais proferidas em questionamentos acerca das decisões do CADE, ver pesquisa realizada pela SOCIEDADE BRASILEIRA DE DIREITO PÚBLICO (SBDP). Revisão judicial das decisões do Conselho Administrativo de Defesa Econômica: pesquisa empírica sobre os casos julgados pelos Tribunais Regionais Federais (TRFs), Superior Tribunal de Justiça (STJ) e Supremo Tribunal Federal (STF). Belo Horizonte: Fórum, 2011.
} 
concorrenciais. Há, portanto, diversos aspectos de interpretação e da aplicação da lei que ainda não foram enfrentados pelos tribunais.

O fato é que o direito da concorrência ainda é matéria para "especialistas", um nicho que, frequentemente, é apresentado como desconectado de outros ramos do direito. Esta "especialidade" do direito da concorrência, aliada à escassa discussão judicial de temas concorrenciais, resulta em um relativo isolamento da disciplina, prejudicando o diálogo entre o direito da concorrência e as disciplinas correlatas (e.g., a disciplina dos contratos) e, ainda, nublando a compreensão mais ampla de institutos do direito da concorrência e suas relações e consequências em outras esferas.

No contexto de relativo isolamento da disciplina e de expectativa acerca da entrada em vigor de uma nova lei de defesa da concorrência, o presente estudo pretende investigar como se encontra a disciplina jurídica do abuso de poder econômico no Brasil, com foco particular nas práticas de distribuição com potenciais efeitos de exclusão. Muitas vezes a disciplina da concorrência é identificada como a disciplina da coibição do abuso do poder econômico. O poder econômico pode ser entendido, assim, como um elemento constitutivo da disciplina da concorrência no Brasil, amparado pelos dispositivos constitucionais que norteiam e nortearam sua aplicação ao longo do tempo. ${ }^{5}$

A repressão ao abuso de poder econômico, prevista na Constituição Federal de 1988, é concretizada principalmente por meio da repressão ao ilícito de posição dominante, que vem regulado nos artigos 20 e 21 da Lei 8.884/94 - e, agora, pelo artigo 36 e parágrafos da Lei $12.527 / 2011$.

Como se sabe, a Lei 12.527/2011 trouxe alterações significativas no que diz respeito ao controle de estruturas de mercado - estabelecendo o controle prévio dos atos de concentração - e redesenhou o chamado Sistema Brasileiro de Defesa da Concorrência (SBDC), unificando e reorganizando funções do Conselho Administrativo de Defesa Econômica (CADE), da Secretaria de Direito Econômico (SDE) e da Secretaria de Acompanhamento Econômico (SEAE). No que diz respeito ao ilícito de abuso de posição dominante, contudo, a Lei 12.527/2011 não trouxe modificações relevantes, sendo que os

\footnotetext{
${ }^{5}$ SALOMÃO FILHO, Calixto. Recusa da contratar: disciplina jurídica. In: Regulação e Concorrência: estudos e pareceres, São Paulo, Malheiros, 2002, p. 137-150.
} 
seus dispositivos que tratam do ilícito de abuso de posição dominante são bastante semelhantes àqueles constantes da Lei 8.884/94.

FORGIONI explica que a disciplina jurídica da concorrência inevitavelmente coloca em conflito, de um lado, segurança e previsibilidade e, de outro lado, insegurança e falta de previsibilidade. ${ }^{6}$ Se o âmbito de aplicação das normas da disciplina da concorrência são as atividades econômicas ${ }^{7}$, dinâmicas por natureza, as normas requerem flexibilidade na sua aplicação. A flexibilidade das normas permite sua adaptação às diversas situações que ocorrem no âmbito das atividades empresariais; contudo, apesar de necessária, a flexibilidade das normas gera um grau relativamente alto de insegurança jurídica e falta de previsibilidade. Nesse contexto, o ilícito de abuso de posição dominante é, possivelmente, um dos aspectos do antitruste em que o nível de incerteza jurídica é dos mais altos, se comparado com outras áreas da disciplina da concorrência, tais como a disciplina relativa aos cartéis e a disciplina dos atos de concentração econômica.

O objeto deste estudo, reiteramos, refere-se aos ilícitos de abuso de posição dominante tendentes à exclusão e, em particular, às práticas de distribuição adotadas por agentes econômicos dominantes que podem ter efeitos de exclusão.

Uma série de casos da jurisprudência internacional e nacional acerca de abuso de posição dominante envolve situações em que estratégias de distribuição adotadas por agentes econômicos que ocupam posição dominante foram questionadas em razão de seu potencial de exclusão. Há um grupo de situações, portanto, que se localiza na intersecção entre casos envolvendo ilícitos de abuso de posição dominante e casos que envolvem estratégias de distribuição com potencial de exclusão. Este grupo de situações é o que interessa ao nosso estudo.

A escolha do tema justifica-se pela riqueza das discussões teóricas envolvidas na avaliação de abusos de posição dominante que tratam de práticas de distribuição tendentes à exclusão e pela importância prática destas discussões, tendo em vista a necessidade de aplicá-las a situações concretas e, assim, buscar conferir conteúdo operacional às normas que disciplinam tais comportamentos.

\footnotetext{
${ }^{6}$ FORGIONI, Paula A. Os Fundamentos do Antitruste. $2^{\text {a }}$ ed. São Paulo: Revista dos Tribunais, 2005.

${ }^{7} \mathrm{VAZ}$, Isabel. As três vertentes do direito da concorrência. In: Revista de Direito Econômico, Conselho Administrativo de Defesa Econômica-CADE, v. 27, janeiro/julho de 1998, p. 36.
} 
Como se sabe, a tarefa da distribuição de bens e serviços é aspecto fundamental da atividade comercial de fornecedores de bens e serviços. De fato, uma das principais tarefas de um fornecedor de bens e serviços é identificar qual a melhor maneira de escoar sua produção, ou seja, identificar qual a forma mais eficiente de fazer que seus produtos cheguem até o consumidor final. ${ }^{8}$

É natural que fornecedores busquem utilizar formas cada vez mais eficientes e inovadoras de distribuir seus produtos, com o objetivo de melhorar o escoamento de sua produção, alocar seus produtos de forma mais visível aos consumidores finais, investir em esforços de promoção a serem empreendidos por seus intermediários, promover a imagem dos seus produtos e serviços, estabelecer descontos e preços atrativos aos intermediários e aos consumidores finais, entre outros. Nesse processo, os fornecedores buscam, naturalmente, aumentar suas vendas e melhorar sua posição competitiva.

Ocorre que, em determinadas circunstâncias, um fornecedor pode ocupar uma posição de domínio em determinados mercados e, seus esforços (em princípio, legítimos), podem ter potenciais efeitos de excluir ou de aumentar os de custos seus concorrentes, possivelmente causando efeitos indesejáveis sobre a concorrência.

Nesse ponto, aparece a questão principal que busca ser respondida neste trabalho: a partir de que momento (ou em que circunstâncias), um comportamento agressivo - e, em princípio desejável - de um agente econômico em posição dominante passa a ser um problema de ordem concorrencial? Qual é a linha divisória entre os comportamentos que podem ser adotadas por agentes econômicos que detêm posição dominante e as condutas que estes agentes não podem adotar, quando se trata de suas estratégias de distribuição?

O trabalho é organizado da seguinte forma.

No Capítulo I, buscaremos contextualizar a disciplina jurídica da concorrência no Brasil, a partir de um breve histórico do seu desenvolvimento, descrevendo sua evolução

\footnotetext{
${ }^{8}$ KORAH, Valentine; O'SULLIVAN, Denis. Distribution Agreements Under the EC Competition Rules, Hart Publishing Limited, 2002, p.1. Os autores esclarecem que um fornecedor de produtos deve resolver basicamente seis problemas: como encontrar clientes; como obter os materiais e componentes (insumos) que precisa para fabricar os seus produtos; como fabricar os produtos; como levar os seus produtos a seus clientes/consumidores (distribuição); como financiar suas operações; e como precaver-se contra incertezas. Ao tratar da tarefa de distribuição (como levar seus produtos a seus clientes/consumidores), necessariamente devem ser feitas considerações sobre as outras cinco tarefas.
} 
até a edição da Lei 12.529/2011, recém promulgada. Em seguida, mapearemos brevemente as possíveis concepções e enfoques da disciplina da concorrência no Brasil, ressaltando que estes diferentes enfoques podem ser explicados devido à complexidade do fenômeno da concorrência. Posteriormente, passaremos à análise dos múltiplos valores que podem permear e orientar a disciplina da concorrência e, finalmente, teceremos comentários acerca dos elementos que podem influenciar a aplicação e a formação do direito da concorrência em diferentes sistemas.

No Capítulo II, com o objetivo de delimitar melhor o tema objeto do trabalho, tentaremos definir a ideia de exclusão, a partir de uma diferenciação, principalmente, entre as ideias de exclusão e colusão e entre os conceitos de exclusão e exploração. Como passo que precede a discussão, teceremos breves comentários acerca dos conceitos de poder econômico, poder de mercado e posição dominante. Em seguida, traçaremos um panorama geral da disciplina jurídica de repressão ao abuso de posição dominante, com foco nos abusos de exclusão, recorrendo, para tanto, a uma análise dos modelos adotados pelo direito da concorrência dos Estados Unidos e do direito comunitário europeu. Buscaremos, ainda, contrastar os dois modelos e examinar o modelo brasileiro. Em seguida, mapearemos as principais dificuldades usualmente enfrentadas na análise dos abusos de posição dominante tendentes à exclusão.

No Capitulo III, buscaremos traçar um panorama das principais linhas teóricas econômicas que oferecem subsídios à compreensão da ideia de exclusão, bem como as contribuições específicas por elas trazidas relacionadas às condutas tendentes à exclusão. Examinaremos, também, algumas das discussões mais recentes relativas às possíveis abordagens oferecidas pela teoria econômica acerca da forma de tratamento destas condutas.

No Capítulo IV, passaremos à análise das possíveis estratégias de distribuição tendentes à exclusão. Examinaremos, no capítulo, o que chamamos de estratégias tradicionais de distribuição e estratégias não tradicionais de distribuição. As estratégias tradicionais referem-se às práticas de distribuição tendentes à exclusão que envolvem questões que já fazem parte do repertório tradicional antitruste, a saber: as práticas de preços predatórios, os acordos de exclusividade, a recusa unilateral de contratar e as vendas casadas ou acordos de vinculação (tying). Em seguida, trataremos do que chamamos de 
estratégias de distribuição não tradicionais, que envolvem os descontos, estratégias promocionais e de alocação de produtos em prateleiras, entre outras práticas, que também têm o potencial de exclusão. Finalmente, faremos uma análise destas estratégias (tradicionais e não tradicionais) à luz da disciplina da concorrência brasileira.

Por fim, no Capítulo V, buscamos fazer um diagnóstico de como se encontra a disciplina da repressão aos abusos de posição dominante, com foco nas práticas de distribuição tendentes à exclusão. Partiremos, então, para uma análise das perspectivas do tema, considerando a nova legislação e a evolução do objeto de estudo. Ao final, segue a conclusão. 


\section{CAPÍTULO I - DIREITO DA CONCORRÊNCIA: ORIGENS, CONCEPÇÕES E VALORES PROTEGIDOS}

\section{INTRODUÇÃO}

Para se ter uma correta compreensão da disciplina de repressão ao abuso de posição dominante no direito brasileiro é necessário considerar, inicialmente, o contexto em que se desenvolveu a disciplina da concorrência no Brasil, bem como o conjunto de valores no qual ela se insere.

Para tanto, entendemos que o direito da concorrência deve ser estudado a partir de sua evolução histórica e de seus fundamentos constitucionais e, também, considerando fatores institucionais e econômicos que influenciaram e continuam a influenciar o seu desenvolvimento ao longo do tempo.

Neste capítulo, portanto, iniciamos com uma breve análise do histórico do desenvolvimento da disciplina da concorrência no Brasil, descrevendo sua evolução até a edição da Lei 12.529/2011, recém promulgada. Em seguida, mapearemos brevemente as possíveis concepções e enfoques da disciplina da concorrência no Brasil, ressaltando que estes diferentes aspectos podem ser explicados devido à complexidade do fenômeno da concorrência. Posteriormente, passaremos à análise dos múltiplos valores que podem permear e orientar a disciplina da concorrência e, finalmente, teceremos comentários acerca dos elementos que podem influenciar a aplicação e a formação do direito da concorrência em diferentes sistemas.

\section{DIREITO DA CONCORRÊNCIA NO BRASIL: ORIGEM HISTÓRICA E BASE CONSTITUCIONAL}

\subsection{Contexto constitucional e evolução legislativa}

Como se sabe, a origem do direito da concorrência no Brasil é geralmente traçada na legislação relacionada à proteção da economia popular. Conforme afirma FERRAZ JUNIOR, "os primeiros diplomas legais, no âmbito econômico, tinham por escopo uma 
classificação de ilicitudes penais, sendo as formas de concentração, o monopólio primordialmente, qualificados como crimes". 9

A liberdade econômica foi protegida pela primeira vez como valor constitucional na Constituição Federal de 1934, dentro dos limites dos princípios da Justiça e das necessidades da vida nacional, de forma a possibilitar a todos existência digna. ${ }^{10} \mathrm{~A}$ Constituição de 1934 estabelecia, ainda, em seu artigo 117, que a "lei promoverá o fomento à economia popular". ${ }^{11} \mathrm{O}$ referido artigo 117, no entanto, jamais chegou a ser regulamentado.

A Constituição Federal de 1937, em seu artigo 141, estabelecia que "a lei fomentará a economia popular, assegurando-lhe garantias especiais". O artigo 141 declarava, também, que "os crimes contra a economia popular são equiparados aos crimes contra o Estado, devendo a lei cominar-lhes penas graves e prescrever-lhes processos e julgamentos adequados à sua pronta punição."

Em 1938, foi editado o Decreto-lei 869, que regulamentou o artigo 141 da Constituição de 1937, definindo quais seriam os crimes contra a economia popular. Por conter alguns dispositivos antitruste ${ }^{12}$, o Decreto-lei $869 / 38$ é considerado por alguns autores como "a primeira norma antitruste brasileira". ${ }^{13}$ Nelson Hungria, autor do projeto que se transformou no Decreto 869/38, ressaltou que a lei tinha o objetivo de defender a economia popular contra os delitos econômicos e promover a defesa da concorrência. ${ }^{14}$

\footnotetext{
${ }^{9}$ FERRAZ JUNIOR, Tércio Sampaio. Concorrência como tema constitucional. In: Revista do IBRAC, São Paulo, v. 16, n.1, 2009, p. 170.

10 “Art. 115. A ordem econômica deve ser organizada conforme os princípios da Justiça e as necessidades da vida nacional, de modo que possibilite a todos existência digna. Dentro destes limites, é garantida a liberdade econômica."

11 “Art. 117. A lei promoverá o fomento da economia popular, o desenvolvimento do crédito e nacionalização progressiva dos bancos de depósito. Igualmente providenciará sobre a nacionalização das empresas de seguros em todas as suas modalidades, devendo constituir-se em sociedades brasileiras as estrangeiras que atualmente operam no País."

${ }^{12}$ FORGIONI explica que o Decreto-lei 869/38 trouxe, pela primeira vez, algumas normas antitruste que perduram até hoje, tais como a coibição de açambarcamento de mercadorias, a manipulação da oferta e da procura, a fixação de preços mediante acordo entre empresas, a exclusividade, entre outros. FORGIONI, Paula A. Os Fundamentos do Antitruste. $2^{a}$ ed., São Paulo: Revista dos Tribunais, 2005, p. 115.

${ }^{13}$ SHIEBER, Benjamim. Abusos do Poder Econômico. Direito e experiência antitruste no Brasil e nos EE.UU. São Paulo: Editora Revista dos Tribunais, 1966, p. 4.

${ }^{14}$ HUNGRIA, Nelson. Dos crimes contra a economia popular. Rio de Janeiro, Livraria Jacinto, 1939, p. 16, apud FRANCESCHINI, José Ignácio Gonzaga, Legislação Brasileira Antitruste. São Paulo, 1986, p. 76.
} 
Mais tarde, ainda durante a vigência da Constituição de 1937, foi editado o Decretolei 7.666 de 1945, que tratava dos "atos contrários à moral e à economia".

Conforme explica FORGIONI ${ }^{15}$, os dois diplomas editados durante a vigência da Constituição de 1937 eram claramente instrumentais à proteção da economia popular, conforme ditames do artigo $141 .{ }^{16}$ É de se registrar, ainda, que os referidos dispositivos constitucionais e legais refletiam uma preocupação com a proteção à economia nacional. Conforme anota VAZ, à época, havia um claro receio de que as grandes empresas multinacionais passassem a exercer um controle indevido sobre as atividades econômicas no país. ${ }^{17}$

A Constituição Federal de 1946 trouxe, pela primeira vez, o princípio da "repressão ao abuso de poder econômico." ${ }^{18}$ Em 1951, foi editada a Lei 1.521, de 26 de dezembro de 1951, que também tratava de crimes contra a economia popular, e, em 1962, foi editada a Lei 4.137.

A Lei 4.137/62 regulamentou a repressão ao abuso do poder econômico, nos termos do artigo 148 da Constituição Federal de 1946, e criou o Conselho Administrativo de Defesa Econômica (CADE). A Lei 4.137/62 significou um marco na evolução dos diplomas concorrenciais brasileiros, pois trouxe uma abordagem distinta da até então existente, que era voltada à proteção da economia popular, de caráter precipuamente penal e marcadamente nacionalista. ${ }^{19}$ Conforme explica SCHIEBER, a Lei 4.137/62 adotou uma linguagem de finalidade ao tratar das diferentes formas de abuso de poder econômico e apenas as considerar abusivas se para dominar mercados, eliminar concorrentes, explorar

\footnotetext{
${ }^{15}$ FORGIONI, Paula A. Os Fundamentos do Antitruste. 2. ed. rev. e atual, São Paulo: Revista dos Tribunais, 2005 , p. 191.

${ }^{16}$ Conforme artigo 141 da Constituição Federal de 1937: “ A lei fomentará a economia popular, assegurando-lhe garantias especiais. Os crimes contra a economia popular são equiparados aos crimes contra o Estado, devendo a lei cominar-lhes penas graves e prescrever-lhes processos e julgamentos adequados à sua pronta e segura punição."

${ }^{17}$ VAZ, Isabel. As três vertentes do direito da concorrência. In: Revista de Direito Econômico, Conselho Administrativo de Defesa Econômica-CADE, v. 27, janeiro/julho de 1998, p. 36.

18 “Art. 148. A lei reprimirá toda e qualquer forma de abuso do poder econômico, inclusive as uniões ou agrupamentos de empresas individuais ou sociais, seja qual for a sua natureza, que tenham por fim dominar os mercados nacionais, eliminar a concorrência e aumentar arbitrariamente os lucros."

${ }^{19}$ FORGIONI, Paula A. Os Fundamentos do Antitruste. $2^{a}$ ed., São Paulo: Revista dos Tribunais, 2005, p. 191.
} 
consumidores. ${ }^{20}$ Vale notar que, na visão de SCHUARTZ, este foi o primeiro diploma antitruste brasileiro em sentido próprio. ${ }^{21}$

A Lei 4.237/62, no entanto, nunca chegou a ser aplicada de forma consistente. ${ }^{22}$ Conforme explica SCHUARTZ, "a orientação intervencionista $e$ até certo ponto cartelizante dos militares era incompatível com uma política consistente de defesa da concorrência e acabou, sem a necessidade de revogação, esvaziando as partes substantivas da lei vigente." 23

Já sob a égide da Constituição Federal de 1988, foi editada a Lei 8.158, de 8 de janeiro de 1991, que seria uma lei de transição. ${ }^{24}$ A Lei 8.158/91 "preparou o terreno" para o desenho institucional que, posteriormente, veio a ser adotado pela Lei 8.884, de 11 de junho de 1994, atualmente em vigor - e prestes a ser modificado pela Lei 12.529/2011, recém editada.

\subsection{A Constituição Federal de 1988, a Lei 8.884/94 e a Lei 12.529/2011}

Conforme FERRAZ JUNIOR, a Constituição Federal de 1988, ao disciplinar a matéria, trouxe elementos novos e, com isto, "a ressurreição da lei antitruste numa nova perspectiva, como peça fundamental no perfil econômico constitucional."25

${ }^{20}$ SHIEBER, Benjamim. Abusos do Poder Econômico. Direito e experiência antitruste no Brasil e nos EE.UU. São Paulo: Editora Revista dos Tribunais, 1966, p. 28.

${ }^{21}$ SCHUARTZ, Luis Fernando. A desconstitucionalização do direito de defesa da concorrência. In: Revista do IBRAC, São Paulo, v. 16, n.1, 2009, p. 330.

${ }^{22}$ FORGIONI, Paula A. Os Fundamentos do Antitruste. $2^{a}$ ed., São Paulo: Revista dos Tribunais, 2005 , p. 129. Conforme explica FORGIONI: “...a Lei Antitruste de 1962 não encontrou uma maior efetividade na realidade brasileira, não sendo possível identificar qualquer atuação linear e constante de uma política econômica que se tenha corporificado em uma política de concorrência."

${ }^{23}$ Conforme explica SCHUARTZ: "Ironicamente, a abertura da Lei 4.137/62 para a recepção de influxos e sinalizações estritamente políticos colaborou para enfraquecer e quase anular sua própria eficácia social, que praticamente apenas sobreviveu, durante a década de 80 e de maneira espasmódica, em iniciativas demagógicas de controle de preços no âmbito da execução dos planos econômicos." SCHUARTZ, Luis Fernando. A desconstitucionalização do direito de defesa da concorrência. In: Revista do IBRAC, São Paulo, v. 16, n.1, 2009, p. 331.

${ }^{24}$ De acordo com SCHUARTZ, a Lei 9.158/91 "serviu para colocar na pista certa a política de defesa da concorrência do País. Mas a decolagem só veio com a lei vigente, a Lei 8.884/94, e um conjunto de sinais mais explícitos e unívocos por parte do governo no sentido da relevância desta política e do apoio aos sujeitos encarregados de executá-la." SCHUARTZ, Luis Fernando. A desconstitucionalização do direito de defesa da concorrência. In: Revista do IBRAC, São Paulo, v. 16, n.1, 2009, p. 332.

${ }^{25}$ FERRAZ JUNIOR, Tércio Sampaio. Concorrência como tema constitucional. In: Revista do IBRAC, São Paulo, v. 16, n.1, 2009, p. 172. 
A Constituição Federal de 1988 estabelece, em seu artigo $1^{\circ}$, os fundamentos da República Federativa do Brasil, entre eles, a dignidade da pessoa humana (inciso III) e os valores sociais do trabalho e da livre iniciativa (inciso IV).

No Título VII (Da Ordem Econômica e Financeira), Capítulo I, a Constituição estabelece os princípios gerais da atividade econômica. O artigo 170 estabelece que " $a$ ordem econômica, fundada na valorização do trabalho humano e na livre iniciativa, tem por fim assegurar a todos existência digna, conforme os ditames da justiça social", observados determinados princípios - entre eles, o da livre concorrência (inciso IV) e da defesa do consumidor (inciso V).

$\mathrm{O}$ artigo 173, parágrafo $4^{\circ}$, por sua vez, estabelece que "a lei reprimirá o abuso do poder econômico que vise à dominação dos mercados, à eliminação da concorrência e ao aumento arbitrário de lucros".

Conforme explicam GRAU e FORGIONI, nos termos da Constituição de 1988, os princípios da livre iniciativa e da livre concorrência são instrumentais à promoção da dignidade humana, conforme os ditames da justiça social. ${ }^{26}$ Por isso, deve-se ter em conta que os objetivos perseguidos pela Constituição Federal brasileira são mais amplos do que o simplesmente o livre mercado; assim, a concorrência, entre nós, "não é um fim em si mesma”. 27

Na mesma linha, TAVARES GUERREIRO já afirmava, em outro contexto, que “ $a$ livre-concorrência é valor-meio, a servir valor-fim, que vem a ser o bem comum e o interesse da coletividade." 28 Tratando em particular sobre a repressão ao abuso do poder

\footnotetext{
${ }^{26}$ GRAU, Eros R. e FORGIONI, Paula. Loterias: Serviços Públicos. Livre Iniciativa/Livre Concorrência e imposição de restrições à atividade dos lotéricos. In: O Estado, a Empresa e o Contrato, São Paulo: Malheiros Editores, 2005, p. 139. No mesmo sentido, ver VAZ: “...o exercício das atividades econômicas ou a ordem econômica que a Lei $n^{o}$ 8.884/94 há de proteger - subordina-se aos fins estabelecidos no caput do artigo 170." VAZ, Isabel. As três vertentes do direito da concorrência. In: Revista de Direito Econômico, Conselho Administrativo de Defesa Econômica - CADE, v. 27, janeiro/julho de 1998, p. 41. Interessante notar que BUCCI, ao tratar dos direitos sociais consubstanciados na Constituição Federal de 1988 que "não há um modelo de políticas sociais distinto do modelo de políticas públicas econômicas. A alteração na ordem jurídica que demanda essa nova conceituação provém da mesma fonte histórica, que é a formação do Estado intervencionista." BUCCI, Maria Paula Dallari. O Conceito de Política Pública em Direito. In: BUCCI, Maria Paula Dallari (org.) Políticas Públicas. Reflexões sobre o Conceito Jurídico. Editora Saraiva, 2006, p. 5.

${ }^{27}$ FORGIONI, Paula A. Os Fundamentos do Antitruste. $2^{\mathrm{a}}$ ed., São Paulo: Revista dos Tribunais, 2005, p. 193. ${ }^{28}$ TAVARES GUERREIRO, José Alexandre. Formas de Abuso de Poder Econômico. In: Revista de Direito Mercantil, Industrial, Econômico e Financeiro, Ano XXVI (nova série), n. 66, abril-junho de 1987, Editora Revista dos Tribunais, p. 49.
} 
econômico, GUERREIRO afirmava que "a repressão a tais modalidades de abuso de poder econômico se insere categoricamente no direito concorrencial e este não se limita à valorização da liberdade de concorrência enquanto valor absoluto e bastante em si mesmo, mas, ao contrário, somente encontra justificativa ética se e enquanto a liberdade de concorrência atende às exigências do bem comum...."

Conforme sintetiza FORGIONI, portanto, o histórico da evolução da legislação concorrencial no Brasil demonstra que ele sempre teve caráter instrumental. De fato, a Constituição Federal de 1988 deixa claro o caráter instrumental da disciplina da concorrência. $^{29}$

No sentido da instrumentalidade da disciplina da concorrência, a Lei 8.884/94 estabeleceu, já em seu artigo $1^{\circ}$, o seu objeto: a prevenção e a repressão às infrações contra a ordem econômica orientada pelos ditames constitucionais de liberdade de iniciativa, livre concorrência, função social da propriedade, defesa dos consumidores e repressão ao abuso do poder econômico. Lei 12.529/2011, que revoga e substitui a Lei 8.884/94 e reestrutura o Sistema Brasileiro de Defesa da Concorrência (SBDC), segue a mesma abordagem e praticamente reproduz o artigo $1^{\circ}$ da Lei 8.884/94.

A Lei 8.884/94 e a recém editada Lei 12.529/2011 concretizam os princípios constitucionais delineados na Constituição Federal de 1988 e, conforme GRAU, sua interpretação deve ser feita em coerência com este conjunto de princípios. ${ }^{30}$ É indiscutível, portanto, que a disciplina da concorrência no Brasil deve ser considerada a partir do conjunto de valores delineados na Constituição Federal de 1988.

\subsection{Principais mudanças trazidas pela Lei 12.529/2011}

Tendo em vista a recém editada Lei 12.529/2011, consideramos necessário tecer alguns comentários acerca das principais mudanças por ela introduzidas.

\footnotetext{
${ }^{29}$ FORGIONI, Paula A. Os Fundamentos do Antitruste. $2^{\mathrm{a}}$ ed., São Paulo: Revista dos Tribunais, 2005 , p. 191.

${ }^{30}$ Conforme GRAU: "As regras da Lei 8.884/94 conferem concreção aos princípios da liberdade de iniciativa, da livre concorrência, da função social da propriedade, da defesa dos consumidores e da repressão ao abuso do poder econômico, tudo em coerência com a ideologia constitucional adotada pela Constituição de 1988. Esses princípios coexistem harmonicamente entre si, conformando-se, mutuamente, uns aos outros. Daí porque o princípio da liberdade de concorrência ou da livre concorrência assume, no quadro da Constituição de 1988, sentido conformado pelo conjunto dos demais princípios por ela contemplados; seu conteúdo é determinado pela sua inserção em um contexto de princípios, no qual e com os quais subsiste em harmonia." GRAU, Eros R. A Ordem Econômica na Constituição de 1988, 11ª ed., São Paulo: Malheiros, 2006, p. 193.
} 
As principais mudanças trazidas pela Lei 12.529/2011 referem-se ao novo desenho institucional do Sistema Brasileiro de Defesa da Concorrência (SBDC) e à introdução de um sistema de análise prévia de atos de concentração. Para fins desta breve introdução à nova lei, interessa-nos em particular o novo desenho institucional adotado pela lei. Isso porque, consideramos que o desenho institucional pode ter uma influência relevante na forma de aplicação das normas de disciplina da concorrência.

Quanto ao desenho institucional, a Lei 12.529/2011 estabelece que o Sistema Brasileiro de Defesa da Concorrência (SBDC) passa a ser formado pelo Conselho Administrativo de Defesa Econômica (CADE) e pela Secretaria de Acompanhamento Econômico do Ministério da Fazenda (SEAE) (art. $3^{\circ}$ ).

Nos termos da nova lei, a SEAE passará a ter diferentes competências das que tem hoje de acordo com a Lei 8.884/94. De acordo com o artigo 19, compete à SEAE "promover a concorrência em órgãos do governo e perante a sociedade." O papel da SEAE passa a ser, em linhas gerais, o de opinar, quando considerar pertinente, acerca de minutas de atos normativos, propostas de alterações legislativas, nos aspectos referentes à promoção da concorrência, elaborar estudos setoriais que sirvam de insumo para a participação do Ministério da Fazenda, propor revisão de leis, entre outros.

O CADE continua a ser uma autarquia federal, vinculada ao Ministério da Justiça, entidade judicante com jurisdição em todo o território nacional (art. $4^{\circ}$ ); no entanto, passa a ser constituído por três órgãos: o Tribunal Administrativo de Defesa Econômica, a Superintendência-Geral e o Departamento de Estudos Econômicos.

O Tribunal Administrativo terá composição e competência semelhantes aos do atual CADE, com algumas diferenças. Os conselheiros do Tribunal Administrativo passam a ter mandatos de 4 (quatro) anos, sem possibilidade de recondução (inciso X do artigo $9^{\circ}$ ).

Entre as competências do Plenário do Tribunal Administrativo estão as de "decidir sobre a existência de infração à ordem econômica" (inciso II, art. 9º) e "decidir os processos administrativos para imposição de sanções administrativas por infrações à ordem econômica instaurados pela Superintendência-Geral"' (inciso III, art. 9º).

Vale notar, ainda, que o parágrafo $2^{\circ}$ do inciso XIX do artigo $9^{\circ}$ estabelece que " $a s$ decisões do Tribunal não comportam revisão no âmbito do Poder Executivo, promovendo- 
se, de imediato sua execução e comunicando-se, em seguida, ao Ministério Público, para as demais medidas legais cabíveis no âmbito de suas atribuições". A Lei 12.529/2011, portanto, a exemplo da Lei 8.884/94, deixa claro que não é possível a interposição de recurso hierárquico e, dessa forma, formalmente fortalece a independência política do órgão.

A Superintendência-Geral será composta por um Superintendente-Geral e 2 (dois) Superintendentes-Adjuntos. As atribuições específicas dos Superintendentes-Adjuntos serão ainda definidas em Resolução (art. 12). Entre as competências da SuperintendênciaGeral estão as de "promover, em face de indícios de infração da ordem econômica, procedimento preparatório de inquérito administrativo e inquérito administrativo para apuração de infrações à ordem econômica" (inciso III, artigo 13) e "instaurar e instruir processo administrativo para imposição de sanções administrativas por infrações à ordem econômica, procedimento para apuração de ato de concentração, processo administrativo para análise de ato de concentração, processo administrativo para imposição de sanções processuais incidentais instaurados para prevenção, apuração ou repressão de infrações à ordem econômica" (inciso V, artigo 13).

Finalmente, o Departamento de Estudos Econômicos será dirigido por um economista-chefe, a quem incumbirá "elaborar estudos e pareceres econômicos, de ofício ou por solicitação do Plenário, do Presidente, do Conselheiro-Relator ou do Superintendente-Geral, zelando pelo rigor e atualização técnica e cientifica das decisões do órgão" (artigo 17). 


\section{CONCEPÇÕES E ENFOQUES DA DISCIPLINA DA CONCORRÊNCIA NO BRASIL}

\subsection{Introdução}

Ao longo do desenvolvimento das normas de defesa da concorrência no Brasil, a doutrina vem tratando a disciplina da concorrência a partir de diferentes enfoques. Tais enfoques são explicados em vista da evolução histórica mencionada no item anterior e da diversidade de abordagens possíveis diante da complexidade do fenômeno da concorrência. Diferentes concepções da disciplina da concorrência no Brasil, portanto, podem ser identificadas a partir da análise dos vários escritos doutrinários a respeito. Tais concepções não são necessariamente excludentes entre si; pelo contrário, devem ser entendidas como complementares, como diferentes enfoques de um mesmo fenômeno.

\subsection{Diferentes enfoques da disciplina da concorrência: panorama}

Em artigo publicado em 1998, VAZ afirma que o direito da concorrência constitui um dos mais importantes ramos do direito econômico, considerado como "a disciplina jurídica que tem por objeto imediato a regulamentação das medidas de política econômica adotadas pelo Estado." ${ }^{31}$ No mesmo artigo, VAZ identificou outras vertentes do direito concorrência, entre elas a tentativa de caracterizar o direito da concorrência como parte de um direito penal econômico.

A vertente que busca conceber o direito da concorrência como parte de um direito penal econômico pode ser compreendida no contexto das primeiras normas concorrenciais, promulgadas a partir de 1938 e até 1962. Tais normas, como já tratamos, tinham nítido caráter penal e tratavam dos crimes contra a economia popular. VAZ explica que estas normas foram editadas em um outro contexto histórico e político, tinham fortes preocupações nacionalistas e foram concebidas para serem aplicadas em outras circunstâncias e por diferentes órgãos governamentais. ${ }^{32}$

VAZ, no entanto, observa que a legislação da concorrência brasileira então vigente (Lei 8.884/94) estava inserida no Título da Constituição que estabelecia os princípios gerais

\footnotetext{
${ }^{31}$ VAZ, Isabel. As três vertentes do direito da concorrência. In: Revista de Direito Econômico, Conselho Administrativo de Defesa Econômica - CADE, v. 27, janeiro/julho de 1998, p. 35.

${ }^{32}$ VAZ, Isabel. As três vertentes do direito da concorrência. In: Revista de Direito Econômico, Conselho Administrativo de Defesa Econômica-CADE, v. 27, janeiro/julho de 1998, p. 36.
} 
das atividades econômicas. Assim, sendo as atividades econômicas dinâmicas por natureza, o Estado "jamais conseguiria coibir abusos correntemente verificados se não pudesse recorrer à analogia, na falta de tipificação expressa de um delito econômico." Prossegue VAZ: "as leis sobre concorrência não podem prescindir de uma certa flexibilidade, necessária ao acompanhamento do dinamismo inerente às atividades econômicas. Este dinamismo e esta flexibilidade encontram-se no Direito econômico, muito mais do que no Direito penal." ${ }^{33}$ Assim, conclui a autora, o Estado precisa de instrumentos flexíveis, maleáveis e dinâmicos para realizar suas políticas econômicas, e o direito penal não disporia de tais instrumentos. No mesmo sentido, FORGIONI defende "a necessidade de flexibilização do texto normativo, destinada a adequá-lo à mutável realidade em que se insere. $^{34}$

VAZ conclui, ainda, em linha com o que desenvolvemos nos itens anteriores, que há fortes argumentos para se considerar que a legislação de proteção da concorrência possui natureza instrumental e reforça que o direito da concorrência deve ser analisado e aplicado no contexto da Constituição Federal. ${ }^{35}$

Deve ser registrado que a conclusão de que a disciplina da concorrência estaria dentro do âmbito do direito econômico e teria natureza instrumental, no entanto, não exclui a existência de um direito penal econômico. De fato, existe um direito penal econômico, que, no que se refere a questões concorrenciais, é concretizado por meio da Lei 8.137/90. A Lei 8.137/90 tipifica como crimes contra a ordem econômica determinadas condutas que, também, podem configurar ilícitos administrativos nos termos da Lei 8.884/94 - e, agora, da Lei $12.529 / 2011 .^{36}$

É de se notar, a propósito, que a recém promulgada Lei 12.529/2011, revogou os dispositivos da Lei 8.137/90 que tratavam de ilícitos relativos a abuso de posição dominante, limitando os ilícitos criminais aos casos de cartéis. Esta alteração veio a confirmar o que já se observava na prática, ou seja, que somente os casos de cartel vinham

\footnotetext{
${ }^{33} \mathrm{VAZ}$, Isabel. As três vertentes do direito da concorrência. In: Revista de Direito Econômico, Conselho Administrativo de Defesa Econômica - CADE, v. 27, janeiro/julho de 1998, p. 36.

${ }^{34}$ FORGIONI, Paula A. Os Fundamentos do Antitruste. $2^{\mathrm{a}}$ ed. São Paulo: Revista dos Tribunais, 2005, p. 201.

${ }^{35}$ VAZ, Isabel. As três vertentes do direito da concorrência. In: Revista de Direito Econômico, Conselho Administrativo de Defesa Econômica-CADE, v. 27, janeiro/julho de 1998, p. 36.

${ }^{36}$ A Lei 8.137/90 engloba não somente os crimes contra a ordem econômica, como também crimes contra a ordem tributária e contra as relações de consumo.
} 
sendo processados também na esfera criminal. Esta abordagem vem ao encontro dos comentários de VAZ no sentido de que as normas de disciplina da concorrência precisam ter alguma flexibilidade, de forma a poder acompanhar o dinamismo das atividades econômicas.

\subsection{O direito da concorrência como instrumento de implementação de políticas públicas}

Como veremos no próximo item, a disciplina da concorrência pode ser direcionada à busca de diferentes objetivos, em diferentes ordenamentos. Tais objetivos podem ser múltiplos e mutáveis ao longo do tempo.

Entre nós, FORGIONI defende que a disciplina da concorrência não somente tem caráter instrumental, mas também que serve como instrumento de implementação de políticas públicas, ${ }^{37}$ especialmente de políticas econômicas. Nessa linha, o direito concorrencial seria encarado como um dos instrumentos de que dispõe o Estado para conduzir o sistema. FORGIONI esclarece, ainda, que a própria não implementação de uma política de concorrência vigorosa pode expressar precisamente a implementação de determinada política.

Nessa linha, BAKER afirma que a política mais ou menos intervencionista acerca de ilícitos de monopolização nos Estados Unidos durante determinados períodos do século passado explica-se em razão de opções de política econômica, de acordo com as quais a política de defesa da concorrência teria tido um papel mais ou menos importante em cada período. $^{38}$

Na Europa, é inegável que a disciplina da concorrência sempre teve um caráter de instrumentalidade, voltada a atingir objetivos de política pública, notadamente a integração do mercado comum. MONTI defende que há, atualmente, uma transformação em andamento com relação à disciplina da concorrência européia: originalmente, os valores centrais de integração de mercado e liberdade econômica eram mais relevantes do que considerações econômicas, mas hoje haveria uma tendência a realocar as prioridades. ${ }^{39}$ Mesmo estas possíveis transformações confirmam sua instrumentalidade, pois não deixam

\footnotetext{
${ }^{37}$ FORGIONI, Paula A. Os Fundamentos do Antitruste. $2^{\mathrm{a}}$ ed. São Paulo: Revista dos Tribunais, 2005 , p. 193.

${ }^{38}$ BAKER, Jonathan B. Preserving a Political Bargain: The Political Economy of the Non-Interventionist Challenge to Monopolization Enforcement. In: Antitrust Law Journal, v. 76, Issue 3, 2010, p. 607-608.

${ }^{39}$ ONTI, Giorgio. EC Competition Law. Cambridge University Press, 2007, p. 51.
} 
de refletir mudanças nas políticas publicas perseguidas pelo direito da concorrência europeu.

Conforme explica BUCCI, o conceito de política pública tem "um componente de ação estratégica, isto é, incorpora elementos sobre a ação necessária e possível naquele momento determinado, naquele conjunto institucional e projeta-os para o futuro mais próximo." 40 Esta visão das políticas públicas é perfeitamente compatível com a ideia de que o direito da concorrência pode servir como instrumento de implementação de políticas públicas.

\subsection{Disciplina da concorrência e mercado: a relação da disciplina da concorrência com o direito comercial: direito da concorrência como microssistema}

Ao traçar um histórico do desenvolvimento da disciplina da concorrência de forma mais geral (não limitada à análise da disciplina no Brasil), FORGIONI aponta que é importante compreender a disciplina da concorrência não somente como aquela que nasce no contexto de um sistema de mercado liberal, mas também se deve reconhecer a existência de normas concorrenciais anteriores à concepção de livre mercado, entendido como próprio de um sistema de produção capitalista. ${ }^{41}$ Tais regras, disciplinadoras da conduta de agentes econômicos, seriam aquelas que teriam sido emanadas "de qualquer poder capaz de impor um sistema munido de sanções externas e institucionalizadas, ou seja, sanções jurídicas, ainda que esse poder seja corporativo".

Esta abordagem parte da constatação de que "a concorrência existe desde que haja comércio, desde que haja mercado". Tal compreensão, portanto, remete a uma concepção da disciplina da concorrência distinta da que é usualmente tratada na maior parte dos escritos sobre o direito da concorrência no Brasil. O direito da concorrência não seria somente uma disciplina ligada à ideia de intervenção do Estado nas atividades econômicas (e, portanto, intrinsicamente ligada ao direito econômico), mas também ligado a regras que disciplinam relações de concorrência entre os agentes econômicos, ainda que não emanadas do poder estatal. Como resume FORGIONI: "existe, portanto, uma diferença fundamental entre a proteção/regulamentação da concorrência, no Estado Liberal, e aquela que lhe foi

\footnotetext{
${ }^{40}$ BUCCI, Maria Paula Dallari. O Conceito de Política Pública em Direito. In: BUCCI, Maria Paula Dallari (org.) Políticas Públicas. Reflexões sobre o Conceito Jurídico. Editora Saraiva, 2006, p. 19.

${ }^{41}$ FORGIONI, Paula A. Os Fundamentos do Antitruste. $2^{\text {a }}$ ed. São Paulo: Revista dos Tribunais, 2005 , p. 28.
} 
anterior. Mas essa diversidade que se coloca pode ser de finalidade e, muitas vezes, não se trata de uma diferença formal das normas utilizadas." 42

Se a concorrência existe desde que haja comércio, desde que haja mercado, parecenos adequado tecer breves comentários acerca do conceito de mercado, para que possamos melhor contextualizar sua relação com a disciplina da concorrência.

O termo "mercado" envolve diversos significados e é utilizado em diferentes contextos para denominar coisas nem sempre coincidentes. ${ }^{43}$ Segundo FERRARESE, o conceito de mercado é geralmente utilizado sem uma prévia indagação analítica, sendo utilizado pela economia como uma "premissa não examinada" (unexamined assumption). Para a economia, o mercado pode ser concebido de diversas formas: como mecanismo de preços, mecanismo de trocas, um lugar abstrato em que compradores e vendedores interagem, um mecanismo de coordenação, uma estrutura de governança, entre outros.

TORRE-SCHAUB ${ }^{44}$ aponta que a onipresença das práticas de mercado nas sociedades contemporâneas levou ao desenvolvimento de ideologias que consideram o mercado como um fenômeno espontâneo ou natural. Segundo a autora, a pujante metáfora da mão invisível, como imagem do bom funcionamento dos mercados, apresenta-se como uma negação de todo um processo de institucionalização dos mercados pelo direito. Se o mercado é considerado como um fenômeno espontâneo, o papel que caberia ao direito seria simplesmente o de reconhecê-lo e de adequar-se a ele. ${ }^{45}$ A ideia de que o mercado seria um locus naturalis, portanto, colocaria o direito como tendo um papel secundário, trazendo a ideia subjacente de neutralidade política, de fenômeno externo e imposto ao direito. ${ }^{46}$

De acordo com COLLINS, comum à ideia de mercado é que ele é construído a partir de padrões de trocas rotineiras e repetitivas, que permitem às partes criar expectativas com relação ao comportamento de outra parte, bem como calcular riscos

\footnotetext{
${ }^{42}$ FORGIONI, Paula A. Os Fundamentos do Antitruste. $2^{\mathrm{a}}$ ed. São Paulo: Revista dos Tribunais, 2005, p. 3132.

${ }^{43}$ FERRARESE, Maria Rosaria, Diritto e mercato, Torino, G. Giappiachelli Editore, 1992, p. 17.

${ }^{44}$ TORRE-SCHAUB, Marthe. Essai Sur La Construction Juridique de La Categorie de Marché. Paris, LGDJ, 2002, p. 1.

${ }^{45}$ IRTI, Natalino. Introdução ao livro Il Dibattito Sull'Ordine Giuridico Del Mercato, Editori Laterza, 1999. Texto traduzido e fornecido pela Profa. Rachel Sztaijn.

${ }^{46}$ IRTI, Natalino. Introdução ao livro Il Dibattito Sull'Ordine Giuridico Del Mercato, Editori Laterza, 1999. Texto traduzido e fornecido pela Profa. Rachel Sztaijn.
} 
inerentes às relações de troca, riscos de ter sua expectativa frustrada pela outra parte. O sucesso das trocas ou das relações contratuais recai sobre aspectos como: comunicação, cooperação e padrões normativos ou expectativas comuns. ${ }^{47}$

Em linha semelhante às considerações de COLLINS, IRTI considera que o mercado é uma ordem, no sentido de regularidade e previsibilidade de agir, governada por regras que definem padrões de comportamento previsíveis, permitindo um cálculo sobre o futuro. IRTI define mercado, ainda, como uma unidade jurídica de relações de troca, esclarecendo que todo mercado é um estatuto de normas. ${ }^{48}$ As normas traduzem e edificam a calculabilidade desta ordem.

IRTI, no entanto, vai além das considerações de COLLINS, e explica que o direito conforma e constitui o mercado, estabelecendo as regras do jogo que influenciam os movimentos dos jogadores. IRTI defende, assim, a ideia de artificialidade do mercado, que tem como consectário seu caráter de politicidade e sua relatividade histórica, sendo construído pelo direito, determinado por decisões políticas. Na síntese de IRTI: "Il mercado non è trovato, ma constituito dal diritto". 49

A concepção de IRTI, portanto, contrapõe-se à ideia de que o mercado seria um fenômeno espontâneo. Como consequência, o papel do direito não é secundário ao mercado, mas sim constitutivo do mercado, não se podendo tampouco falar de neutralidade política. $^{50}$

Em cuidadoso estudo sobre a evolução do direito comercial brasileiro, FORGIONI sintetiza as muitas visões acerca do conceito de mercado e identifica diferentes perfis do mercado. A autora explica que o mercado é um fenômeno poliédrico e que apresenta diferentes perfis ou dimensões, todas interdependentes entre si: a dimensão econômica, ligada à ideia de lócus, onde se davam as trocas entre os comerciantes; a dimensão política,

\footnotetext{
${ }^{47}$ COLLINS, Hugh. Regulating Contracts. Oxford University Press, 1999, p. 98.

${ }^{48}$ IRTI, Natalino. L'Ordine Giuridico del Mercato, In: L'Ordine Giuridico del Mercato. Editori Laterza, 2001, p.5.

${ }^{49}$ IRTI, Natalino. Persona e Mercato. In: IRTI, Natalino. L'Ordine Giuridico del Mercato. Editori Laterza, 2001, p. 67.

50 “A tese - exposta, precisamente, nas três palavras: artificialidade, juridicidade, historicidade - expressa, de forma nítida e taxativa, a rejeição de qualquer naturalismo econômico, no qual o direito aparece como simples imagem ou reprodução de uma ordem que seja primeira e fora dele." IRTI, Natalino. A ordem jurídica do mercado. In: Revista de Direito Mercantil, Industrial, Econômico e Financeiro, Vol. 145, Ano XLVI (nova Série), janeiro-março/2007, Malheiros Editores, p. 44.
} 
que, nas palavras da autora, "emerge da consideração do papel que a competição (ou o modelo de competição) exercerá como fator de alocação de recursos na sociedade", sendo sua compreensão indispensável, para situar a função reservada ao direito; a dimensão social, que, também nos dizeres da autora, impõe a formatação de sua dimensão política e econômica; e sua dimensão jurídica, que revela o conjunto de regras e princípios que pauta o comportamento dos agentes econômicos. ${ }^{51}$

Se o mercado é compreendido não como fenômeno espontâneo - em que o papel do direito é secundário -, mas como constituído ou moldado pelo direito, a pergunta que nos cabe é: qual o papel da disciplina da concorrência na formatação ou na moldagem do mercado?

Recorremos, aqui, novamente, às considerações de FORGIONI, que aponta que os princípios constitucionais econômicos são instrumentais ao funcionamento do mercado e são "a fôrma que primeiramente moldará o mercado." 52 Assim, os princípios constitucionais que embasam as normas concorrenciais atuam na moldagem do mercado. Nesta linha, o principio da livre iniciativa, por exemplo (ligado à liberdade de empresa), seria instrumental à garantia de acesso dos agentes econômicos ao mercado (à arena de disputas); o princípio da livre concorrência, por sua vez, garante aos agentes econômicos a oportunidade de disputar trocas com outros agentes econômicos.

Em síntese, os princípios constitucionais econômicos estabelecem o quadro de valores a partir dos quais deve ser compreendida a disciplina da concorrência e são também instrumentais ao funcionamento do mercado.

FORGIONI aponta que, hoje, uma das principais questões enfrentada pelos teóricos do direito comercial é justamente a compreensão do mercado. ${ }^{53}$ Assim, parece-nos que não é possível situar a disciplina da concorrência fora do contexto do direito comercial.

Segundo FORGIONI, o direito comercial brasileiro sempre se desdobrou em diplomas esparsos, que disciplinaram a atividade dos agentes econômicos em legislações

\footnotetext{
${ }^{51}$ FORGIONI, Paula Andrea. A evolução do direito comercial brasileiro: da mercancia ao mercado. São Paulo, Editora Revista dos Tribunais, 2009, p. 190 e seguintes.

${ }^{52}$ FORGIONI, Paula A. A evolução do direito comercial brasileiro: da mercancia ao mercado. São Paulo, Editora Revista dos Tribunais, 2009, p. 204 e seguintes.

${ }^{53}$ FORGIONI, Paula A. A evolução do direito comercial brasileiro: da mercancia ao mercado. São Paulo, Editora Revista dos Tribunais, 2009, p. 188.
} 
específicas, em regras colocadas fora do Código Comercial. ${ }^{54} \mathrm{Um}$ dos exemplos destas legislações específicas citadas pela autora é justamente a Lei 8.884/94. A profusão de leis específicas, conforme explica a autora, pode ser entendida no contexto do fenômeno da decodificação, conforme identificado por IRTI, em seu L'etá della decodificazzioni. IRTI observou não serem mais os códigos o centro do sistema e constatou a proliferação de leis específicas e o desenvolvimento de microssistemas. Nessa linha, a disciplina da concorrência pode ser compreendida como um microssistema do direito comercial.

Em linha semelhante, GONÇALVES também considera que o direito da concorrência hoje pode ser compreendido como um microssistema. ${ }^{55}$ Os microssistemas seriam leis especiais, "corpos orgânicos de normas, dedicados de forma permanente à disciplina de certas categorias de relações jurídicas, dotados de lógica e autonomia próprias, e voltados para a tutela de valores específicos". ${ }^{56}$ Prossegue a autora: "ao discutirmos os limites da intervenção estatal e os parâmetros para a aplicação do direito econômico na sociedade brasileira contemporânea não podemos perder de vista os valores perseguidos pelo microssistema em questão, tampouco as ferramentas escolhidas pelos legisladores (constituintes ou ordinários) para a obtenção dos fins almejados por aqueles conjuntos específicos de normas." ${ }^{, 57}$ Conclui a autora que "além das considerações sobre tempo e local, que traduzem a já comentada historicidade do direito econômico, há que se observar os objetivos do microssistema específico (v.g., o direito antitruste), a sua racionalidade e modo de atuação." 58

A disciplina da concorrência, portanto, pode ser compreendida como um microssistema do direito comercial (conforme FORGIONI) e também como um microssistema do direito econômico (conforme GONÇALVES). Parece-nos, assim,

\footnotetext{
${ }^{54}$ FORGIONI, Paula A. A evolução do direito comercial brasileiro: da mercancia ao mercado. São Paulo, Editora Revista dos Tribunais, 2009, p. 177.

${ }^{55}$ Conforme concepção desenvolvida por IRTI na mesma obra L'etá della decodificazzioni. Milano: Giuffré, 1999, pp. 38-39.

${ }^{56}$ GONÇALVES. Priscila Brolio. A obrigatoriedade de contratar no direito antitruste. Editora Singular, 2010, p. 31 .

${ }^{57}$ GONÇALVES. Priscila Brolio. A obrigatoriedade de contratar no direito antitruste. Editora Singular, 2010, p. 32.

${ }^{58}$ GONÇALVES. Priscila Brolio. A obrigatoriedade de contratar no direito antitruste. Editora Singular, 2010, p. 33.
} 
adequado situar a disciplina da concorrência na intersecção entre o direito comercial e o direito econômico.

Em nosso entender, esta visão da disciplina da concorrência - afeta tanto ao direito comercial quanto ao direito econômico - contribui para uma compreensão da disciplina que a torna menos uma questão para "especialistas", mas um tema que extrapola a compreensão de tratar-se de disciplina relacionada exclusivamente à ideia de intervenção do Estado na economia. Como consequência, o "relativo isolamento" da disciplina tenderia a se arrefecer, na medida em que, mais do que um tema limitado à intervenção do Estado (relação Estadoadministrado), trata-se também de um tema afeto à relação entre agentes econômicos. Desta conclusão, decorre que a disciplina da concorrência pode ser utilizada no contexto de discussões entre agentes econômicos, que podem (inclusive por meios processuais já existentes) travar disputas entre si, principalmente perante o judiciário, independente de ações de intervenção estatal.

\subsection{Direito da concorrência e os direitos ou interesses coletivos}

Uma concepção pouco explorada pela doutrina - e que nos parece relevante mencionar - insere e contextualiza o direito da concorrência no âmbito dos direitos ou interesses coletivos ou transindividuais.

Como se sabe, o sistema de proteção dos chamados interesses ou direitos difusos ou coletivos no Brasil está, hoje, consolidado basicamente na Lei 7.347, de 24 de julho de 1985 (Lei da Ação Civil Pública) e na Lei 8.078, de 11 de setembro de 1990 (Código de Defesa do Consumidor). A interação entre as duas leis resulta na compreensão dos chamados interesses ou direitos difusos, coletivos e individuais homogêneos, que vieram positivados e sistematizados no artigo 81 do Código de Defesa do Consumidor. ${ }^{59}$

Conforme explica a doutrina, a construção e a sistematização dos interesses coletivos ou difusos foi resultado do trabalho de juristas brasileiros que, inspirados no

\footnotetext{
59 “Art. 81. A defesa dos interesses e direitos dos consumidores e das vítimas poderá ser exercida em juízo individualmente, ou a título coletivo. Parágrafo único. A defesa coletiva será exercida quando se tratar de: I - interesses ou direitos difusos, assim entendidos, para efeitos deste código, os transindividuais, de natureza indivisível, de que sejam titulares pessoas indeterminadas e ligadas por circunstâncias de fato; II - interesses ou direitos coletivos, assim entendidos, para efeitos deste código, os transindividuais, de natureza indivisível de que seja titular grupo, categoria ou classe de pessoas ligadas entre si ou com a parte contrária por uma relação jurídica base; III - interesses ou direitos individuais homogêneos, assim entendidos os decorrentes de origem comum."
} 
movimento italiano da década de 70, trabalharam na busca da formulação e consolidação de uma nova mentalidade e impulsionaram movimentos legislativos, cientes da necessidade de se buscar "novas técnicas para a tutela efetiva de interesses cujas dimensões extravasam do quadro bem definido das relações interindividuais." 60 A Lei da Ação Civil Pública e o Código de Defesa do Consumidor são resultado destes esforços e consolidaram o sistema brasileiro para a tutela dos interesses ou direitos difusos ou coletivos. ${ }^{61}$

GRINOVER sintetiza as características distintivas dos interesses coletivos ou difusos, conforme desenvolvidos pelos italianos, da seguinte forma: "indeterminados pela titularidade, indivisíveis com relação ao objeto, colocados a meio caminho entre os interesses públicos e os privados, próprios de uma sociedade de massa e resultado de conflitos de massa, carregados de relevância política...". ${ }^{62}$

Os escritos acerca do direito da concorrência no Brasil, contudo, fazem pouca menção às referências incluídas na Lei 8.884/94 acerca da Lei da Ação Civil Pública e do Código de Defesa do Consumidor, que foram reproduzidas parcialmente pela Lei $12.529 / 2011$.

O artigo 29 da Lei 8.884/94 faz referência ao Código de Defesa do Consumidor ao estabelecer que: “os prejudicados, por si ou pelos legitimados do art. 82 da Lei no 8.078, de 11 de setembro de 1990, poderão ingressar em juízo para, em defesa de seus interesses individuais ou individuais homogêneos, obter a cessação de práticas que constituam infração da ordem econômica, bem como o recebimento de indenização por perdas e danos sofridos, independentemente do processo administrativo, que não será suspenso em virtude

\footnotetext{
${ }^{60}$ MOREIRA, José Carlos Barbosa. A ação popular no direito brasileiro como instrumento de tutela jurisdicional dos chamados interesses difusos. In: Revista de Processo, n. 28, p. 7. Tal esforço insere-se no contexto da chamada "segunda onda renovatória", delineada por Mauro Cappelletti e Bryant Garth como uma das soluções para o problema de acesso à justiça. CAPPELLETTI, Mauro; GARTH, Bryant. Acesso à Justiça. Tradução de Ellen Gracie Northfleet. Porto Alegre: Sergio Antonio Fabris, 1988.

${ }^{61}$ A este respeito, interessante observação de BUCCI sobre o papel destas normas na implementação de políticas públicas: “... a elaboração mais desenvolvida no direito a respeito das políticas públicas não está no campo do direito público - como seria de se esperar, em virtude da interação obrigatória dos agentes públicos com os instrumentos jurídicos-institucionais que balizam a atuação do Poder Público -, mas no campo processual." BUCCI, Maria Paula Dallari. O Conceito de Política Pública em Direito. In: BUCCI, Maria Paula Dallari (org.) Políticas Públicas. Reflexões sobre o Conceito Jurídico. Editora Saraiva, 2006, p. 5. ${ }^{62}$ GRINOVER, Ada Pellegrini. Significado Social, Político e Jurídico da tutela dos interesses difusos. In: Revista de Processo n. 97, p. 9.
} 
do ajuizamento de ação."63 $\mathrm{O}$ artigo 29, portanto, prevê a possibilidade de que prejudicados possam buscar a tutela judicial não somente individualmente ${ }^{64}$, mas também coletivamente.

$\mathrm{O}$ artigo 83, por sua vez, estabelece que: "aplicam-se subsidiariamente aos processos administrativo e judicial previstos nesta lei as disposições do Código de Processo Civil e das Leis $n^{\circ} 7.347$, de 24 de julho de 1985 e $n^{\circ} 8.078$, de 11 de setembro de 1990." ${ }^{65}$ Finalmente, o artigo 88 alterou a redação do artigo $1^{\circ}$ da Lei de Ação Civil Pública e incluiu a este artigo o inciso $\mathrm{V}$, sendo que o referido artigo passou a viger com a seguinte redação: "regem-se pelas disposições desta lei, sem prejuízo da ação popular, as ações de responsabilidade por danos morais e patrimoniais causados: ...V - por infração da ordem econômica". 66

GRINOVER é categórica ao afirmar que a Lei 8.884/94 se insere no campo dos direitos e interesses transindividuais, apontando que o parágrafo único do artigo $1^{\circ}$ da Lei 8.884/94 estabelece que "a coletividade é a titular dos bens jurídicos protegidos por esta lei”. ${ }^{67}$ GRINOVER explica, ainda, que " $a$ inquestionável a concepção da tutela dos interesses difusos ou coletivos, por intermédio da Lei 8.884/94, veio também especificada em seu artigo 88 (...)", que, como indicado no parágrafo anterior, incluiu o item V ao artigo $1^{\circ}$ da Lei de Ação Civil Pública.

${ }^{63} \mathrm{O}$ artigo foi praticamente reproduzido na Lei $12.529 / 2011$, em seu artigo 47, que estabelece: " $O s$ prejudicados, por si ou pelos legitimados referidos no art. 82 da Lei no 8.078, de 11 de setembro de 1990, poderão ingressar em juízo para, em defesa de seus interesses individuais ou individuais homogêneos, obter a cessação de práticas que constituam infração da ordem econômica, bem como o recebimento de indenização por perdas e danos sofridos, independentemente do inquérito ou processo administrativo, que não será suspenso em virtude do ajuizamento de ação."

${ }^{64} \mathrm{Em}$ nosso entender, a possibilidade de prejudicados por violações à Lei 8.884/94 - e, agora, por violações à Lei 12.529/2011 - não precisaria estar expressamente prevista na lei concorrencial. Isto porque, instrumentos processuais outros já garantiriam este direito aos prejudicados, independentemente da menção feita no artigo 29 da Lei 8.884/94.

${ }^{65} \mathrm{O}$ artigo foi praticamente reproduzido no artigo 115 da Lei 12.529/2011, conforme a seguir: "Aplicam-se subsidiariamente aos processos administrativo e judicial previstos nesta Lei as disposições das Leis nos 5.869, de 11 de janeiro de 1973 - Código de Processo Civil, 7.347, de 24 de julho de 1985, 8.078, de 11 de setembro de 1990, e 9.784, de 29 de janeiro de 1999."

${ }^{66}$ A redação do inciso foi posteriormente modificada pela Medida Provisória n. 2.180-35, 2001, passando a vigorar da seguinte forma: " $V$ - por infração da ordem econômica e da economia popular."

${ }^{67}$ GRINOVER, Ada Pellegrini. O termo de ajustamento de conduta no âmbito da defesa da concorrência. In: Revista do IBRAC, v. 16-1, p. 187 -189. Nas palavras de GRINOVER: "Estamos inquestionavelmente no campo dos direitos e interesses transindividuais, que transcendem os direitos meramente individuais, e de que são titulares pessoas não identificadas e frequentemente não identificáveis, que integram grupos, categorias ou classes cujos membros são ligados por um vínculo social e de solidariedade, não estando unidas por nenhuma relação-jurídica base, mas sim por circunstâncias de fato." 
Em razão da interação e correlação entre a Lei da Ação Civil Pública e o Código de Defesa do Consumidor, GRINOVER conclui que a tutela dos interesses difusos e coletivos, no campo da defesa da concorrência, se perfaz por todos os instrumentos contemplados pela Lei de Ação Civil Pública.

Dessa conclusão - a de que a Lei 8.884/94 se insere no campo dos direitos e interesses transindividuais - decorrem algumas consequências práticas relevantes. De início, reconhece-se a possibilidade de ajuizamento de ações civis públicas fundadas em violações à Lei 8.884/94 - e agora à Lei 12.529/2011. Além disto, reconhece-se o papel do Ministério Público e outros legitimados para o ajuizamento destas ações na busca da implementação da lei. Assim, não obstante as discussões acerca da disciplina da concorrência atualmente estarem centradas nas lides administrativas, levadas por terceiros ou iniciadas de ofício pelas autoridades brasileiras de defesa da concorrência, há outros atores legitimados a buscar a implementação da lei por meios processuais diversos e movidos por outros incentivos (e.g. a defesa de consumidores prejudicados pelas violações, busca de ressarcimento por danos decorrentes de possíveis violações à lei).

É razoável dizer que a possibilidade de o ajuizamento de ações civis públicas ainda não foi totalmente absorvida pela cultura jurídica brasileira, havendo notícia de poucas ações do tipo ajuizadas com base em infrações previstas na Lei 8.884/94. Neste sentido, vale mencionar que, em recente monografia, CARVALHO faz um levantamento de ações ajuizadas buscando reparação de danos causados por ilícitos concorrenciais entre os anos de 2001 e 2011, tendo encontrado apenas 13 (treze) ações coletivas fundadas em violações à Lei 8.884/94. ${ }^{68} \mathrm{O}$ número de ações do tipo é ainda pouco expressivo, principalmente se considerarmos a existência e a profusão de ações coletivas ajuizadas com fundamento em outros diplomas, tais como os relativos ao direito ambiental e ao Código de Defesa do Consumidor.

Um dos exemplos mais conhecidos da implementação das normas concorrenciais por meio de ações coletivas refere-se à ação civil pública ajuizada pelo Ministério Público Federal contra a Associação Nacional de Empresas Transportadoras de Veículos (ANTV) e

\footnotetext{
${ }^{68}$ CARVALHO, Livia C. L. Gândara. Responsabilidade Civil Concorrencial: a busca da efetiva reparação de danos. Trabalho de Conclusão de Curso apresentado à Escola de Direito FGV, em 16 de novembro de 2011.
} 
outros. O objetivo da ação era abrir o segmento de mercado para os chamados “cegonheiros" autônomos na área de transporte de veículos, fabricados pela empresa General Motors. O Tribunal Regional Federal da $4^{\text {a }}$ Região, ao decidir agravo de instrumento interposto pelas rés, concordou com a existência de indícios de abuso de poder econômico e criação de empecilhos à entrada de novas empresas, confirmando a decisão de tutela antecipada proferida pelo juízo de primeiro grau. ${ }^{69}$

O fato de haver meios processuais e entidades legitimadas para propor ações do tipo citado demonstra que a implementação da Lei 8.884/94 não está adstrita aos órgãos administrativos do Sistema Brasileiro de Defesa da Concorrência (SBDC). Como consequência, é possível que os tribunais passem a examinar questões relacionadas à disciplina da concorrência sob enfoques não necessariamente coincidentes com os geralmente adotados pelo SBDC. Isto porque estes outros "atores", legitimados a buscar a implementação da lei, podem trazer argumentos diferentes e inovadores quanto à interpretação da lei e, portanto, contribuir para uma discussão mais ampla e variada acerca da sua aplicação. Novamente, esta compreensão acerca da disciplina da concorrência pode arrefecer a situação de isolamento da disciplina a médio e longo prazo.

\subsection{Síntese}

Em resumo, a disciplina da concorrência pode ser encarada a partir de diferentes enfoques e concepções. Sendo a concorrência fenômeno complexo, pode ser concebida como ramo do direito econômico (concepção intrinsicamente ligada à noção de intervenção do Estado na economia), como instrumento de implementação de políticas públicas, como instrumento necessário ao funcionamento do mercado, como um microssistema (situado na intersecção entre o direito comercial e o direito econômico) e como inserida no contexto de direitos ou interesses coletivos. Estas concepções não se excluem, mas são apenas diferentes enfoques de um mesmo fenômeno, que podem enriquecer as discussões acerca da disciplina da concorrência e, possivelmente, aos poucos, arrefecer o relativo isolamento da disciplina em relação a disciplinas correlatas.

\footnotetext{
${ }^{69}$ Contra a decisão do Tribunal Regional Federal da 4 a Região, a ANTV apresentou recurso especial ao Superior Tribunal de Justiça (Recurso Especial n. 677.5858-RS), ainda pendente de decisão.
} 


\section{VALORES PROTEGIDOS E OBJETIVOS DO DIREITO DA CONCORRÊNCIA}

\subsection{Introdução}

Já se disse que o direito da concorrência não existe no vácuo: ele é a expressão dos valores e objetivos de uma sociedade e é tão suscetível a mudanças quanto o pensamento político de forma geral. ${ }^{70} \mathrm{O}$ direito da concorrência pode ter objetivos diferentes em diferentes sistemas jurídicos e, em cada ordenamento, os objetivos podem mudar ao longo do tempo.

Como veremos, ainda, as normas de disciplina da concorrência podem ser influenciadas e moldadas a partir de fatores históricos, de objetivos de política pública, aspectos institucionais e processuais. Tais fatores interagem entre si continuamente, exercem papéis e pressões diferentes em cada momento histórico, inevitavelmente moldando as normas e impactando em sua aplicação a situações concretas. ${ }^{71}$

Definir qual o objetivo (ou qual a função) das normas concorrenciais não é tarefa simples, mesmo se examinarmos um sistema jurídico de forma isolada. De forma geral, não se pode falar na existência de um único objetivo das normas concorrenciais. ${ }^{72}$ Em cada sistema jurídico, as normas concorrenciais podem se destinar a atingir um grupo de objetivos e podem exercer um grupo de funções diferentes, mutáveis ao longo do tempo e

\footnotetext{
${ }^{70}$ Conforme WHISH: “...competition policy does not exist in a vacuum: it is na expression of the current values and aims of society and is as susceptible to change as political thinking generally. Because views and insights shift iver a period of time, competition law is infuse with tension. Differente systems of competition law reflect different concerns...". WHISH, Richard. Competition Law. 5th Edition, LexisNexis Buttersworths, 2005 , p. 19.

71 “... within each country, the purposes of competition law can change over time, even without an amendment to the legislative texts. This is possible because of the open-textured nature of most antitrust legislation, which allows for considerable variety in interpretation. Understanding competition law this is not only about dissecting legislative texts and judicial decisions according to settled canons of interpretation, but it is also about understanding the particular forces that have influenced the direction of competition law at particular times." MONTI, Giorgio. EC Competition Law. Cambridge University Press, 2007, p. 3.

72 ".... while it is true that any specific decision in a competition case requires a prior resolution as to the aims of the law, to date no competition authority has deployed competition law in accordance with one unchanging set of aims - the goals of antitrust vary over time; even at the same time, the law can be pursuing different, event mutually contradictory, goals." MONTI, Giorgio. EC Competition Law. Cambridge University Press, 2007, p. 3. Conforme explica FORGIONI, "a restrita visão de tentar subsumir a Lei Antitruste a um único objetivo decorre, também, da compreensão destas normas como um mero instrumento para eliminar os efeitos autodestrutíveis do mercado (função de preservação dos meios de reprodução do capital), sem que seja considerada a política econômica que por essas pode ser autuada." FORGIONI, Paula A. Os Fundamentos do Antitruste. $2^{\mathrm{a}}$ ed. São Paulo: Revista dos Tribunais, 2005, p.164.
} 
não necessariamente convergentes. ${ }^{73}$ Pode-se afirmar, ainda, que há, muitas vezes, uma tensão entre os objetivos e funções exercidas pelas normas concorrenciais.

MONTI afirma, em referência a texto de FOX sobre a disputa acerca de qual seria a "alma" do antitruste nos Estados Unidos ${ }^{74}$, que é impossível identificar a "alma" do antitruste. Segundo MONTI, possível seria identificar diferentes opiniões sobre os objetivos que as normas concorrenciais devem buscar atingir. MONTI vai além e afirma que nenhuma autoridade de defesa da concorrência conseguiu, até hoje, aplicar o direito da concorrência a partir de um único e imutável grupo de objetivos, pois os objetivos variam de acordo com o tempo e, até em um mesmo momento, a lei pode perseguir objetivos diferentes e, até, contraditórios entre si. ${ }^{75}$

A indagação sobre os objetivos das normas antitruste foi identificada por BORK no clássico livro Antitrust Paradox, datado de 1978, como essencial à definição da própria racionalidade das políticas antitruste. Conforme afirmou BORK, uma política antitruste não poderia ser racional, enquanto não se pudesse responder à indagação acerca de qual o objetivo - ou os objetivos - das normas concorrenciais. Todo o resto, afirmava BORK, derivaria da resposta que fosse dada a esta pergunta. Ainda, se as normas concorrenciais perseguissem mais de um objetivo, perguntava BORK, como poderia o aplicador das normas decidir em hipóteses de conflito entre valores e objetivos? Em conclusão, BORK afirmava que, apenas quando a questão dos objetivos estivesse definida, seria possível estabelecer um corpo coerente de normas substantivas. ${ }^{76}$

\footnotetext{
${ }^{73}$ Conforme NUSDEO: "A tutela da concorrência e a repressão aos abusos do poder econômico são objetivos de caráter múltiplo, inseridos no próprio conjunto da política econômica de cada país, com o qual devem guardar uma necessária coerência. É por esse motivo que se tem observado, ao longo da história econômica dos vários países, posições e atitudes diversas frente aos mesmos. Tal diversidade tem refletido menos diferenças de cunho doutrinário e ideológico e muito mais as preocupações com as metas assinadas para a economia de cada país em determinados momentos históricos." NUSDEO, Fabio. Verbete "Abuso do Poder Econômico", Enciclopédia Saraiva do Direito, vol. 2, Ed. Saraiva, p. 121.

${ }^{74}$ FOX, Eleanor M. The Battle for the Soul of Antitrust. In: California Law Review, v. 75, n. 3, Symposium: Anticipating Antitrust's Centennial, May 1987, pp. 917-923.

75 "...it is impossible to identify the "soul" of competition law; the most that can be done is to show that there are different, equally legitimate opinions as to what competition law should achieve." MONTI, Giorgio. EC Competition Law. Cambridge University Press, 2007, p. 2. FORGIONI afirma que a própria indagação acerca de qual o objetivo de uma lei antitruste é equivocada, pois "não há um objetivo geral que possa ser perseguido, e qualquer tentativa de se estabelecer um escopo único está fadada ao insucesso". FORGIONI, Paula A. Os Fundamentos do Antitruste. $2^{\mathrm{a}}$ ed. São Paulo: Revista dos Tribunais, 2005, p. 24-25.

76 "Antitrust policy cannot be made rational until we are able to give a firm answer to one question: What is the point of the law - what are its goals? Everything else follows from the answer we give. Is the antitrust
} 
Diversos objetivos serviram e servem de inspiração às normas antitruste em diferentes países. Entre eles, podemos citar, de forma exemplificativa: a proteção dos consumidores (que não deve ser confundida com a proteção ao "bem estar do consumidor" em termos técnicos ${ }^{77}$; a proteção de concorrentes e das pequenas empresas (que parece permear algumas decisões europeias); a promoção da integração de mercado (específico ao direito concorrencial comunitário europeu $)^{78}$; a garantia de liberdade econômica e proteção ao processo concorrencial (conforme linha teórica ligada à Escola Ordoliberal de Freiburg); a eficiência econômica; o bem estar econômico e o bem estar do consumidor.

As discussões teóricas existentes na literatura antitruste sobre os objetivos da disciplina concorrencial são infindáveis e continuam presentes nos debates acerca de determinados aspectos das normas concorrenciais. Este debate tem relevância para a disciplina do abuso de posição dominante, pois pode resultar em posturas mais ou menos rígidas ou conservadoras quanto a condutas adotadas por agentes em posição dominante, podendo ter como consequência diferentes decisões, a partir de fatos e circunstâncias semelhantes.

\subsection{Valores e objetivos econômicos e não econômicos}

GAVIL, KOVACIC e BAKER buscam classificar e sumarizar os objetivos das normas concorrenciais em objetivos de natureza econômica e objetivos de natureza nãoeconômica. Em linhas gerais, os objetivos de natureza econômica seriam aqueles que a

judge to be guided by one value or by several? If by several, how is he to decide cases where a conflict in values arises? Only when the issue of goals has been settled is it possible to frame a coherent body of substantive rules." BORK, Robert H. The Antitrust Paradox. A Policy at War with Itself. The Free Press, 1993, p. 50. A indagação de BORK, um dos principais teóricos ligados à chamada Escola de Chicago, repercutiu e repercute até hoje nas discussões sobre os objetivos das normas antitruste nos Estados Unidos e é frequentemente referida em escritos que buscam tratar dos objetivos das normas concorrenciais, de forma mais geral.

${ }^{77}$ WHISH observa que o objetivo de proteção aos consumidores não se identifica com o "bem estar do consumidor" em sentido técnico. WHISH, Richard. Competition Law. 6th Edition, LexisNexis Buttersworths, 2008, p. 20. No Brasil, a proteção aos consumidores aparece como um objetivo mediato da disciplina da concorrência, conforme afirma FORGIONI. A autora adverte ainda que "a proteção ao consumidor a que se refere a Lei Antitruste é bastante restrita e não constitui uma das suas pautas de interpretação geral, ao contrário do que ocorre com a livre concorrência e a livre iniciativa". FORGIONI, Paula A. Os Fundamentos do Antitruste. $2^{\mathrm{a}}$ ed. São Paulo: Revista dos Tribunais, 2005, p. 295.

78 "For a long time, the achievement of market integration has been the most prominent goal of European Competition Law." VAN DEN BERGH, Roger. The difficult reception of economic analysis in European Competition Law, In: CUCINOTTA, Antonio; PARDOLESI, Roberto; VAN DEN BERGH, Roger (eds.) Post-Chicago Developments in Antitrust Law. New Horizons in Law and Economics Series, Edward Elgar, 2002, p. 36. 
sociedade espera atingir por meio da operação dos mercados. Os objetivos não-econômicos seriam aqueles temas mais enraizados e historicamente persistentes, tais como: preocupações com mercados muito concentrados; busca por uma concorrência justa e uma desconfiança acerca fenômenos econômicos que poderia ameaçar estabilidade política. ${ }^{79}$

PITFOSKY identificou como principais valores políticos (não-econômicos) do antitruste nos Estados Unidos a preocupação de que a concentração excessiva de poder econômico poderia dar ensejo a pressões políticas antidemocráticas, um desejo de incrementar a liberdade econômica e uma preocupação de que um foco exclusivo em preocupações econômicas poderia levar a resultados indesejáveis. ${ }^{80}$

GAVIL, KOVACIC e BAKER consideram que o principal objetivo econômico da disciplina da concorrência seria impedir a aquisição ou o exercício de "poder de mercado", conforme definido pela microeconomia. ${ }^{81} \mathrm{Um}$ ou mais agentes econômicos podem exercer poder de mercado quando reduzem a oferta ou restringem a concorrência ao aumentar preços acima de um nível competitivo. Em linha semelhante, BISHOP e WALKER afirmam que o conceito econômico de poder de mercado se encontra no centro da avaliação econômica da política antitruste. ${ }^{82}$

Ao tratar de objetivos econômicos da disciplina da concorrência, não podemos deixar de tratar, ainda que brevemente, da ideia de eficiência econômica.

Conforme relatam KIRKWOOD e $\mathrm{LANDE}^{83}$, ao propor a pergunta acerca de qual seria o objetivo de uma política antitruste, BORK também propôs uma resposta: a política antitruste deveria ter como objetivo maximizar a eficiência econômica. ${ }^{84}$

\footnotetext{
${ }^{79}$ GAVIL, Andrew I; KOVACIC, William E.; BAKER, Jonathan B. Antitrust Law in Perspective: Cases, Concepts and Problems in Competition Policy. American Casebook Series, Thompson West, Second Edition, 2008, p. 16.

${ }^{80}$ PITOFSKY, Robert. The Political Content of Antitrust. In: University of Pennsylvania Law Review, v. 127, n. 4, April 1979, p. 1051.

${ }^{81}$ GAVIL, Andrew I; KOVACIC, William E.; BAKER, Jonathan B. Antitrust Law in Perspective: Cases, Concepts and Problems in Competition Policy. American Casebook Series, Thompson West, Second Edition, 2008, p. 16.

${ }^{82}$ BISHOP, Simon; WALKER, Mike. The Economics of EC Competition Law: Concepts, Applications and Measurement. London, Sweet \& Maxwell, 2002, 42. Os possíveis conceitos de poder de mercado serão tratados em maiores detalhes no Capítulo III.

${ }^{83}$ KIRKWOOD, John B.; LANDE, Robert H. The Chicago School's Foundation is Flawed: Antitrust Protects Consumers, Not Efficiency. In: PITOFSKY, Robert (Ed.). How the Chicago School Overshot the Mark. The
} 
FOX explica, contudo, que eficiência é um conceito multifacetado e complexo, e que as formas de atingir eficiência também são complexas. ${ }^{85}$

KIRKWOOD e LANDE discordam da visão de BORK - e da visão da Escola de Chicago em geral -, no que diz respeito à afirmativa de que o objetivo da legislação antitruste seria a maximização da eficiência econômica. De acordo com os autores, o principal objetivo das leis antitruste seria a prevenção da transferência de renda "injusta" de compradores para agentes econômicos com poder de mercado. Nesse sentido, o objetivo da legislação antitruste deveria ser concebido como uma forma de proteção ao consumidor, no sentido de evitar esta transferência injusta de renda. ${ }^{86}$

KIRKWOOD e LANDE sustentam que a jurisprudência norte-americana mais recente tem adotado a abordagem de que o antitruste deve proteger o bem estar do consumidor, e não a eficiência econômica ${ }^{87}$ Os autores esclarecem, ainda, que o termo "bem estar do consumidor" é ambíguo e que esta ambigüidade teria origem no fato de que BORK identificava os dois conceitos como sendo um só, ou seja, que bem estar do consumidor e eficiência da economia seriam a mesma coisa.

Effect of Conservative Economic Analysis of U.S. Antitrust, Oxford University Press, 2008, p. 89. De acordo com os autores, a eficiência econômica teria se tornado o gospel da Escola de Chicago.

${ }^{84}$ BORK, Robert H. Legislative Intent and the Policy of the Sherman Act. In: Journal of Law and Economics, v. 9, 1966. Neste artigo, BORK buscou demonstrar que a história legislativa do Sherman Act conduziria a esta conclusão.

${ }^{85}$ Conforme FOX: “...efficiency and how to reach it are complex concepts. There is no one thing called "efficiency". Conduct, transactions, and markets have efficiency and inefficiency properties at the same time, and the relative dimensions of each property are affected by assumptions regarding how well markets work. How one applies goals of efficiency, therefore, depends on what one values and stresses, as well as hunches as to what will produce the most efficiency - in all of its senses." FOX, Eleanor M. The Efficiency Paradox. In: PITOFSKY, Robert (Ed.). How the Chicago School Overshot the Mark. The Effect of Conservative Economic Analysis of U.S. Antitrust, Oxford University Press, 2008, p. 81. Como se sabe, em linhas gerais, a eficiência pode ser categorizada como eficiência alocativa, eficiência produtiva ou eficiência dinâmica. Para uma descrição didática destes conceitos, ver WHISH. WHISH, Richard. Competition Law. 6th Edition, LexisNexis Buttersworths, 2008, p. 4-7.

${ }^{86}$ KIRKWOOD, John B.; LANDE, Robert H. The Chicago School's Foundation is Flawed: Antitrust Protects Consumers, Not Efficiency. In: PITOFSKY, Robert (Ed.). How the Chicago School Overshot the Mark. The Effect of Conservative Economic Analysis of U.S. Antitrust, Oxford University Press, 2008, p. 90.

${ }^{87}$ Afirmam os autores: "When courts use the term "consumer welfare", moreover, they do not appear to be referring to economic efficiency. Judges rarely describe the goals of antitrust as enhancing efficiency and, more important, the never say that conduct that harms consumers in the relevant market is justified if it increases the efficiency of the economy. " KIRKWOOD, John B.; LANDE, Robert H. The Chicago School's Foundation is Flawed: Antitrust Protects Consumers, Not Efficiency. In: PITOFSKY, Robert (Ed.). How the Chicago School Overshot the Mark. The Effect of Conservative Economic Analysis of U.S. Antitrust, Oxford University Press, 2008, p. 93. 
FOX explica, ainda, que a legislação antitruste não "produz eficiência", porque ela é prospectiva e não prescritiva. A legislação antitruste pode preservar um ambiente em que firmas tenham o incentivo para se comportar de forma competitiva. Esta perspectiva de preservação de um ambiente de mercado competitivo, por sua vez, ajudaria a preservar os incentivos que produzem eficiência. ${ }^{88}$ FOX considera, ainda, que limitar o antitruste exclusivamente à análise de eficiência econômica, nas linhas propostas pela Escola de Chicago, reduziria ao máximo o escopo da legislação antitruste e, ao fazer isto, acabaria por prejudicar a eficiência - daí decorreria o que a autora se refere como o "paradoxo da eficiência". De acordo com FOX, prevenir resultados ineficientes também seria um objetivo das normas antitruste, mas assegurar um processo competitivo seria o objetivo principal contra possíveis resultados concorrenciais indesejáveis, inclusive em termos de eficiência econômica.

Apesar de as discussões acima terem como pano de fundo a política antitruste norteamericana, estas são relevantes diante da sua repercussão para outros sistemas jurídicos, inclusive para o direito concorrencial europeu e o direito da concorrência brasileiro.

\subsection{Valores e objetivos podem ser deduzidos a partir das origens históricas da disciplina concorrencial em cada sistema jurídico}

Pode-se afirmar que os objetivos e funções da disciplina da concorrência em cada sistema jurídico podem ser deduzidos a partir das suas origens e evolução históricas.

Como vimos, no caso do Brasil, o direito da concorrência sempre teve caráter instrumental. Se considerarmos o Decreto-lei 869/38 como a primeira norma antitruste brasileira, podemos observar que, em sua origem, as normas eram instrumentais à proteção da economia popular, inspiradas também por preocupações relativas à proteção da economia nacional. Já com a evolução legislativa e, pelo menos a partir da Lei 8.884/94, as normas de defesa da concorrência brasileiras passaram a ser instrumentais aos princípios constitucionais econômicos previstos na Constituição Federal de 1988. A Constituição de 1988, por sua vez, trouxe os princípios da livre concorrência, livre iniciativa e da repressão

\footnotetext{
${ }^{88}$ FOX, Eleanor M. The Efficiency Paradox. In: PITOFSKY, Robert (Ed.). How the Chicago School Overshot the Mark. The Effect of Conservative Economic Analysis of U.S. Antitrust, Oxford University Press, 2008, p. 79-80.
} 
ao abuso de poder de econômico como instrumentais à proteção da dignidade humana e da justiça social.

Outro exemplo, ainda, refere-se às normas comunitárias europeias da concorrência. Em sua origem, o direito comunitário europeu tinha, como um de seus principais propósitos, a integração do mercado comum europeu, sendo inspirada, ainda, por ideais de justiça (fairness). ${ }^{89}$ Aos poucos, com a consolidação do mercado comum, outros aspectos passaram a ter mais relevância na aplicação das normas. A doutrina mais recente europeia tem enfatizado o papel do bem estar do consumidor como um dos principais objetivos do direito concorrencial comunitário europeu. ${ }^{90}$ Esta ênfase pode ser observada não só nos discursos das autoridades responsáveis pela aplicação das normas, bem como em alterações legislativas relativas a controle de concentração, práticas horizontais, acordos verticais e mesmo abuso de posição dominante.

Na discussão sobre os objetivos das normas antitruste, ainda, é inevitável a referência aos debates ideológicos que permearam o desenvolvimento do direito antitruste dos Estados Unidos, ao longo de sua história. Os debates ideológicos confundem-se com os debates sobre as linhas teóricas econômicas, que serão tratadas em maiores detalhes no Capítulo III. De forma geral, como já dito no item anterior, no período em que prevaleceram os pressupostos teóricos da Escola da Chicago, a ideia de "eficiência econômica" chegou a ser considerada como objetivo único ou principal a ser perseguido pelas normas antitruste norte-americanas. Esta abordagem, no entanto, foi questionada por diversos autores e posteriormente arrefecida, de forma que hoje são reconhecidos outros valores, não limitados à ideia da eficiência econômica.

No Brasil, mesmo situando as normas concorrenciais brasileiras dentro do quadro constitucional, é preciso ter em mente que as normas de concorrência instrumentalizam valores e princípios. A interpretação dos princípios, combinada com o caráter aberto de

\footnotetext{
${ }^{89}$ HAWK, Barry E. Article 82 and Section 2: Abuse and Monopolization Conduct. In: Issues in Competition Law and Policy, Volume II, 2008, ABA Section of Antitrust Law, p. 887.

90 "Originally, one of the main goals of European competition policy was the promotion of market integration...The emphasis on market integration is one of the determinants for a policy that is more based on legal form, rather than on economic content. With progress made toward realization of the internal market, the relative importance of the market integration goal has declined. As a result, policy statements today stress efficiency, consumer welfare, and competitiveness." RÖLLER, Lars-Hendrick; STEHMANN, Oliver. The Year 2005 at DG Competition: The Trend Towards a More Effects-Based Approach. In: Review of Industrial Organization, v. 29, 2005, p. 281.
} 
muitos dos conceitos utilizados pelas normas concorrenciais (desenho legislativo), resultam em uma situação em que o direito da concorrência brasileiro é bastante permeável a influências de diversos elementos, que podem moldá-lo e influenciar a sua aplicação às situações concretas.

Alguns dos principais elementos que impactam a formação e a aplicação do direito da concorrência serão tratados a seguir. 


\section{ELEMENTOS QUE INFLUENCIAM A APLICAÇÃO E A FORMAÇÃO DO DIREITO DA CONCORRÊNCIA}

\subsection{Introdução}

A aplicação das normas concorrenciais pode ser influenciada por uma série de fatores que não estão limitados ao seu desenho legislativo. O desenho legislativo, adotado por cada país, ou os dispositivos legais específicos, são apenas um dentre vários aspectos que impactam a aplicação do direito concorrencial em cada sistema e têm, portanto, relativa importância na própria formação do conteúdo das normas a na sua aplicação a situações concretas.

MONTI propõe que a aplicação das normas concorrenciais pode ser influenciada pela interação de três principais componentes: um componente de decisão política; um componente de decisão econômica, relativo às decisões acerca das premissas econômicas adotadas, ou seja, as premissas acerca de como funcionam os mercados; e, finalmente, um componente de ordem institucional, relacionado às instituições responsáveis pela aplicação das normas concorrenciais. ${ }^{91}$ MONTI observa que a interação destes três componentes pode moldar a direção das normas concorrenciais e que, em momentos distintos, pode exercer diferentes tipos e níveis de pressão na aplicação da disciplina da concorrência.

Apesar de a esquematização proposta por MONTI ser útil, os componentes identificados se mesclam e se relacionam mutuamente, não sendo possível isolar um componente do outro. A seguir trataremos, inicialmente, dos possíveis desenhos legislativos e, posteriormente, dos componentes que podem moldar as normas da disciplina da concorrência de forma geral.

\subsection{Possíveis desenhos legislativos}

É certo que a estrutura das normas legais relativas à disciplina jurídica da concorrência pode ser mais ou menos suscetível à influência de fatores "externos". As normas de disciplina da concorrência podem ser gerais e abertas e, portanto, ser mais ou menos permeáveis a mudanças de objetivos de política pública e/ou a desenvolvimentos da teoria econômica.

\footnotetext{
${ }^{91}$ MONTI, Giorgio. EC Competition Law. Cambridge University Press, 2007, p. 4.
} 
Conforme anotam GAVIL, KOVACIC e BAKER, o Sherman Act dos Estados Unidos exemplifica uma estrutura de regras gerais que deixa margem significativa para interpretação das autoridades responsáveis por sua aplicação. A generalidade das normas estabelecida pelo Sherman Act, confere-lhes flexibilidade e possibilidade de adaptação às mudanças acerca das visões sobre a política antitruste a ser aplicada em cada contexto histórico e econômico, bem como aos desenvolvimentos da teoria econômica potencialmente aplicável. ${ }^{92}$ Em linha semelhante, GELLHORN, KOVACIC e CALKINS observam que a estrutura das normas contidas no Sherman Act confere uma permeabilidade do sistema antitruste a novas ideias, que podem influenciar a direção da teoria e da análise antitruste ao longo do tempo. ${ }^{93}$

GAVIL, KOVACIC e BAKER apontam, ainda, que a estrutura de alguns dos dispositivos da legislação europeia segue uma abordagem mais detalhada sobre comportamentos que podem configurar ilícitos e, portanto, mais fechadas. ${ }^{94}$ Este seria o caso do artigo 101 do Tratado CE, que trata de acordos entre agentes econômicos. ${ }^{95}$ Como veremos adiante, no entanto, o artigo 102 do Tratado CE, relativo ao ilícito de abuso de posição dominante, permite razoável margem de discricionariedade por parte das autoridades responsáveis por sua aplicação. ${ }^{96}$

No Brasil, interessa-nos, para os fins deste estudo, os dispositivos que tratam da disciplina da repressão ao abuso de posição dominante.

\footnotetext{
${ }^{92}$ GAVIL, Andrew I; KOVACIC, William E.; BAKER, Jonathan B. Antitrust Law in Perspective: Cases, Concepts and Problems in Competition Policy. American Casebook Series, Thompson West, Second Edition, 2008 , p. 58.

93 "The antitrust system's permeability influences the direction of antitrust doctrine and analysis over time. ... Because the system is susceptible to new ideas, changing political and economic conditions coupled with ferment in economic learning import instability to existing doctrine and analysis." GELLHORN, E.; KOVACIC, W. E.; CALKINS, S.. Antitrust Law and Economics in a Nutshell. 5th Edition. Thompson West, 2004, p. 49.

${ }^{94}$ GAVIL, Andrew I; KOVACIC, William E.; BAKER, Jonathan B. Antitrust Law in Perspective: Cases, Concepts and Problems in Competition Policy. American Casebook Series, Thompson West, Second Edition, 2008, p. 58.

${ }^{95}$ Em Dezembro de 2009, o Tratado de Lisboa entrou em vigor e incluiu nova numeração aos artigos do Tratado Estabelecendo a Comunidade Europeia. O artigo 101 refere-se ao antigo artigo 81 e o 102 refere-se ao antigo artigo 82. UNIÃO EUROPEIA. Tratado sobre o Funcionamento da União Europeia, Jornal Oficial da União Europeia, 9 de maio de 2008, disponível em http://eurlex.europa.eu/JOHtml.do?uri=OJ:C:2008:115:SOM:PT:HTML, acesso em novembro de 2011.

${ }^{96}$ MONTI, Giorgio. EC Competition Law. Cambridge University Press, 2007, p. 160.
} 
Nos termos da Lei 8.884/94, as infrações à ordem econômica devem ser examinadas à luz dos seus artigos 20 e 21. O artigo 21 contém um rol exemplificativo e não exaustivo de condutas que, caso incidam em qualquer dos incisos do artigo 20, podem configurar uma infração à ordem econômica. ${ }^{97} \mathrm{O}$ artigo 20, por sua vez, estabelece que "constituem infração à ordem econômica, independentemente de culpa, os atos sob qualquer forma manifestados, que tenham por objeto ou possam produzir" os seguintes efeitos: limitar, falsear ou de qualquer forma prejudicar a livre concorrência ou a livre iniciativa (inciso I); dominar mercado relevante de bens ou serviços (inciso II); aumentar arbitrariamente os lucros (inciso III); e exercer de forma abusiva a posição dominante (inciso IV).

O parágrafo $1^{\circ}$ do artigo 20 esclarece que a dominação de mercado em si não configura um ilícito, quando a conquista de mercado for resultante de processo natural fundado na maior eficiência de agente econômico em relação a seus concorrentes. Ainda, o parágrafo $2^{\circ}$ define posição dominante quando "uma empresa ou grupo de empresas controla parcela substancial de mercado relevante, como fornecedor, intermediário, adquirente ou financiador de um produto, serviço ou tecnologia a ele relativa". Por fim, o parágrafo $2^{\circ}$ do artigo 20 esclarece que a posição dominante será presumida "quando a empresa ou grupo de empresas controlar $20 \%$ (vinte por cento) de mercado relevante, podendo este percentual ser alterado pelo CADE para setores específicos da economia."

Da leitura destes dispositivos, que foram praticamente reproduzidos pela Lei $12.529 / 2011^{98}$, pode ser deduzido um dos principais aspectos relativo às infrações à ordem econômica e, portanto, à disciplina de repressão ao abuso de posição dominante: a forma do ato não é relevante para que se configure uma infração à ordem econômica. Assim, nos termos da Lei 8.884/94 - e, também, da Lei 12.529/2011 -, a ilicitude de uma determinada conduta é caracterizada a partir de seus efeitos. ${ }^{99}$

A abordagem da Lei 8.884/94 - caracterização do ilícito pelos efeitos - e a utilização de conceitos abertos conferem a flexibilidade necessária à dinâmica das relações

\footnotetext{
${ }^{97}$ Conforme explica FARACO quanto ao artigo 21 da Lei 8.884/94: “O legislador tentou...indicar qual seria o âmbito daqueles preceitos vagos, sem criar uma tipicidade que tornasse a lei obsoleta diante da realidade cambiante das relações econômicas." FARACO, Alexandre Ditzel. Regulação e Direito Concorrencial, As Telecomunicações. São Paulo: Livraria Paulista, 2003, p. 215.

${ }^{98}$ A redação dos dispositivos equivalentes na Lei 12.529/2011 será tratada no Capítulo II.

${ }^{99}$ FORGIONI, Paula A. Os Fundamentos do Antitruste. $2^{\text {a }}$ ed., São Paulo: Revista dos Tribunais, 2005 , p. 146-147.
} 
econômicas e, consequentemente, uma razoável margem de discricionariedade na sua interpretação. Esta abordagem oferece também uma permeabilidade a elementos "externos" ao desenho legislativo, entre eles a utilização do instrumental econômico na análise dos comportamentos dos agentes econômicos e a possibilidade de adaptação a diferentes objetivos de política pública em diferentes contextos históricos e econômicos.

\subsection{Decisões políticas, decisões econômicas e desenho institucional}

Ao tratar do componente de decisão política, MONTI esclarece referir-se à escolha dos objetivos do direito da concorrência em cada ordenamento. A disciplina da concorrência pode ser direcionada a objetivos que variam entre a busca do bem estar econômico e configurar um instrumento relevante para atingir diversos outros objetivos relacionados a critérios ligados a decisões de política pública.

Quanto ao componente de decisão econômica, MONTI indica que a escolha da linha teórica adotada pode resultar em uma postura mais ou menos intervencionista por parte das autoridades que aplicam o direito da concorrência. Estas posturas e os diferentes graus de intervencionismo podem ser exemplificados a partir da análise do histórico da abordagem adotada pelas autoridades antitruste dos Estados Unidos, em diversas épocas, no que diz respeito aos ilícitos de monopolização, como veremos em maiores detalhes adiante (Capítulo III). ${ }^{100}$

Como dito, no entanto, parece-nos difícil isolar componentes de decisão política dos demais componentes identificados por MONTI. A própria definição do desenho institucional - tratada em maiores detalhes adiante - pode ser considerada uma opção política, pois que define quais serão as instituições responsáveis pela sua aplicação, como estas serão compostas, qual o nível de controle sobre estas instituições, como serão indicados seus membros, entre outros aspectos.

De forma semelhante, a opção por determinadas premissas econômicas (ou linhas teóricas econômicas) a serem aplicadas, também tem um conteúdo político ou ideológico.

\footnotetext{
100 A este respeito, ver, especificamente, BAKER. BAKER, Jonathan B.. Preserving a Political Bargain: The Political Economy of the Non-Interventionist Challenge to Monopolization Enforcement. In: Antitrust Law Journal, v. 76, Issue 3, 2010, p. 605-652.
} 
A este respeito, vale notar que, em artigo publicado em 1979, PITOFSKY observa que, na década de 1970, havia uma tendência à adoção de uma abordagem exclusivamente econômica na análise antitruste nos Estados Unidos. ${ }^{101}$ No referido artigo, PITOFSKY critica esta tendência e ressalta o conteúdo político do antitruste, argumentando que os valores políticos (não econômicos) não poderiam ser desconsiderados e, na verdade, estariam embutidos nas teorias econômicas predominantes. PITOFSKY oferecia, dessa forma, uma crítica à Escola de Chicago, que propunha-se "apolítica" e defendia que seu modelo oferecia bases "científicas" e, portanto, neutras de conteúdo político. ${ }^{102}$

Parece-nos, portanto, que tanto as decisões de ordem institucional, quanto as de ordem econômica, embutem uma decisão política.

\subsection{Componentes institucionais}

Quanto ao componente institucional, MONTI ressalta que a escolha do desenho institucional pode também afetar o resultado da interpretação das normas. Em sentido semelhante, WHISH afirma que, muitas vezes, a política de concorrência pode não ser tão afetada pela busca de algum objetivo ou política em particular, mas referir-se à questão sobre quais as instituições tomam decisões acerca de como os agentes econômicos podem ou não conduzir seus negócios. ${ }^{103}$

WHISH prossegue e propõe algumas indagações: se um sistema define que deve haver uma autoridade responsável por decidir quais comportamentos comerciais são ou não aceitáveis do ponto de vista concorrencial, que tipo de instituição deve tomar tais decisões? Ainda, como devem ser indicados os indivíduos para ocupar cargos nestas instituições? Finalmente, deve haver algum controle destas instituições e, caso positivo, quem deve exercer este controle? ${ }^{104}$

Neste ponto, é interessante ressaltar que alguns países/jurisdições adotam um sistema em que a disciplina da concorrência é aplicada precipuamente por meio de autoridades administrativas. A composição destes órgãos, a forma de indicação de seus

\footnotetext{
${ }^{101}$ PITOFSKY, Robert. The Political Content of Antitrust. In: University of Pennsylvania Law Review, v. 127, n. 4, April 1979, p. 1051.

${ }^{102}$ HOVENKAMP, Herbert. Antitrust Policy After Chicago. In: Michigan Law Review, v. 84, p. 212-284.

${ }^{103}$ WHISH, Richard. Competition Law. 5th Edition, LexisNexis Buttersworths, 2005, p. 24.

${ }^{104}$ WHISH, Richard. Competition Law. 5th Edition, LexisNexis Buttersworths, 2005, p. 25.
} 
membros e o grau de independência são aspectos que podem influenciar os resultados de decisões em casos concretos. Por outro lado, alguns países, podem adotar um modelo descentralizado e dar maior ênfase à aplicação das normas pelos tribunais, pois permitem ou criam incentivos e mecanismos processuais para um maior grau de implementação por agentes privados. ${ }^{105}$

O sistema adotado pelos Estados Unidos, por exemplo, é de uma aplicação descentralizada das normas antitruste, em que diversos "atores" têm um papel na implementação da lei e podem iniciar procedimentos (administrativos ou judiciais) buscando a sua aplicação. Além dos dois órgãos administrativos governamentais (Department of Justice e a Federal Trade Commission), os attorney general dos diversos estados norte-americanos também podem iniciar procedimentos buscando questionar práticas potencialmente anticoncorrenciais. Ainda, agentes privados (e.g., pessoas jurídicas, pessoas físicas, consumidores, concorrentes ou fornecedores) têm um papel relevante na aplicação das normas antitruste nos Estados Unidos, e podem ajuizar ações individuais ou coletivas. ${ }^{106}$ Os Estados Unidos, portanto, adotam uma variedade formas pelas quais as normas antitruste podem vir a ser implementadas.

Esta descentralização institucional significa que diversos atores têm diferentes possibilidades, incentivos e mecanismos, para iniciar procedimentos administrativos ou ajuizar ações judiciais e, portanto, trazer argumentos que podem servir para fundamentar seus pedidos. Assim, o fato de um órgão administrativo governamental possivelmente rejeitar determinadas teorias ou argumentos não impede que outros atores (e.g. agentes privados) possam trazer estas mesmas teorias e buscar convencer os tribunais de que elas seriam válidas. ${ }^{107}$

\footnotetext{
${ }^{105}$ GAVIL, Andrew I; KOVACIC, William E.; BAKER, Jonathan B. Antitrust Law in Perspective: Cases, Concepts and Problems in Competition Policy. American Casebook Series, Thompson West, Second Edition, 2008, p. 57.

${ }^{106}$ GAVIL, Andrew I; KOVACIC, William E.; BAKER, Jonathan B. Antitrust Law in Perspective: Cases, Concepts and Problems in Competition Policy. American Casebook Series, Thompson West, Second Edition, 2008, p. 58.

107 "No single prosecutorial gatekeeper controls access to the courts or decides what ideas may be asserted to support antitrust claims. Decentralized authority to sue means that one entity's rejection of certain theories does not bar others from relying on those theories to bring cases and attempting to persuade judges to accept them." GELLHORN, E.; KOVACIC, W. E.; CALKINS, S.. Antitrust Law and Economics in a Nutshell. 5th Edition. Thompson West, 2004, p. 41.
} 
Na Europa, a implementação das normas comunitárias de concorrência foi, historicamente, e ainda é, primordialmente, feita de forma centralizada, por meio da Comissão Europeia. A Comissão Europeia, no entanto, tem tomado diversas medidas nos últimos anos, para descentralizar a implementação dos artigos 101 e 102 do Tratado CE, por meio de atos normativos que permitem a implementação pelos Estados-Membros ${ }^{108} \mathrm{e}$ por iniciativas destinadas a incentivar a implementação das normas defesa da concorrência por agentes econômicos privados. ${ }^{109}$ Tais iniciativas reconhecem que os recursos da Comissão Europeia são limitados para tratar de todas as situações que potencialmente podem envolver problemas concorrenciais e, ainda, reconhecem que iniciativas de agentes privados podem servir de forma complementar à atuação da Comissão na aplicação das normas.

No Brasil, como já tratamos, questões concorrenciais ainda são primordialmente discutidas no âmbito do Sistema Brasileiro de Defesa da Concorrência (SBDC), ou seja, em sede de procedimentos administrativos, envolvendo investigações de condutas anticompetitivas ou atos de concentração. Assim, a aplicação das normas de disciplina da concorrência ainda é feita de forma centralizada, por meio das autoridades administrativas, a partir das lides administrativas que são levadas a estas autoridades (ou iniciadas pelas próprias autoridades). Não obstante, como também já indicado, a legislação brasileira prevê mecanismos processuais diversos que permitem a aplicação das normas de defesa da concorrência por agentes econômicos privados e por entidades legitimadas a propor ações civis públicas, estas últimas nos termos do sistema de tutela coletiva, aplicáveis às infrações à ordem econômica.

\footnotetext{
${ }^{108}$ A este respeito, ver Resolução 1/2003, cujo principal objetivo era permitir que os tribunais e as autoridades nacionais dos Estados-Membros dividissem com a Comissão Europeia o papel de implementar as normas comunitárias concorrenciais.

${ }^{109}$ Neste sentido, em dezembro de 2005, a Comissão Europeia publicou o Livro Verde sobre Damages actions for breach of the EC antitrust rules e, em abril de 2008, publicou um Livro Branco sobre o mesmo tema. Os dois documentos estão disponíveis em http://ec.europa.eu/competition/antitrust/actionsdamages/index.html, acesso em novembro de 2011. Mais recentemente, entre fevereiro e abril de 2011, a Comissão Europeia colocou em consulta pública um estudo que buscava uma abordagem coerente para a possibilidade de busca de soluções por meio de tutelas coletivas (collective redress) que pudessem ser aplicadas à disciplina da concorrência. Os documentos relacionados a esta consulta pública estão disponíveis em http://ec.europa.eu/competition/consultations/2011_collective_redress/index_en.html, acesso em novembro de 2011.
} 
Não cabe, nos limites do nosso estudo, identificar os motivos do ainda incipiente número de ações judiciais propostas no Brasil com base nestes outros mecanismos. Cabe registrar, no entanto, que é possível que, em um futuro próximo, com o maior conhecimento por parte dos potenciais prejudicados por condutas anticompetitivas acerca das possibilidades de tutela judicial, haja uma gradual descentralização da implementação das normas de disciplina da concorrência. Como consequência, é possível que outros "atores" - e não somente as autoridades que compõem o SBDC - passem a ter maior influência na formação e na aplicação das normas concorrenciais brasileiras. Nesta linha, a participação de outros atores e a gradual descentralização da aplicação da disciplina da concorrência podem, também, arrefecer a situação de isolamento da disciplina da concorrência.

\subsubsection{Instituições e o papel da teoria econômica}

No contexto dos componentes que podem influenciar a aplicação e a moldagem do direito concorrencial, GERBER ressalta o papel não somente das instituições, mas também dos aspectos processuais inerentes a cada sistema de defesa da concorrência. GERBER argumenta que o desenho institucional de cada sistema condiciona o uso da análise econômica, que suas práticas e processos influenciam não somente as regras que são aplicadas, mas também definem o papel que a análise econômica pode desempenhar, bem como o material fático que é produzido para o uso dos economistas e, por consequência, influenciam as decisões que são tomadas na aplicação das normas. ${ }^{110}$

GERBER argumenta que, em cada ordenamento, a teoria econômica é aplicada por diferentes instituições (ou a partir de diferentes modelos institucionais) e, portanto, está sujeita às influências institucionais e processuais particulares de cada sistema. Os contextos institucionais irão moldar as decisões de suas próprias maneiras, e estas podem, com frequência, conduzir a diferentes papéis para a análise econômica, com resultados

\footnotetext{
110 "Institutions condition the use of economics. Their practices and procedures influence not only the norms that are applied, including the appropriate role of economics, but also the factual material that is produced for use by economists and the myriad decisions that are made in reaching outcomes." GERBER, David J. Competition Law and the Institutional Embeddedness of Economics, November 24, 2008, In: DREXL, Josef; IDOT, Laurence; MONÉGER, Joel. Economic Theory and Competition Law, Cheltenham: Elgar, 2009, p. 2043.
} 
potencialmente muito diferentes, dependendo do contexto institucional e processual de cada sistema.

Argumenta GERBER, portanto, que, não obstante o caráter de universalidade da ciência econômica, a presunção de que a adoção de linhas teóricas pelas autoridades concorrenciais de determinado país teria efeitos semelhantes quando aplicadas por outras, seria equivocada. Isso porque, como já dito, diferenças em contextos institucionais e processuais condicionam a forma de aplicação da análise econômica em cada contexto decisório.

Como veremos nos próximos capítulos, no contexto dos ilícitos de abuso de posição dominante, é comum que haja uma comparação entre os sistemas adotados nos Estados Unidos e na Europa e muitos autores indicam que a ausência de convergência entre os dois modelos se justifica por uma abordagem formalista e menos econômica por parte das autoridades de defesa da concorrência europeias. Esta visão, como veremos, desconsidera o que GERBER chama de "enraizamento institucional da economia" (institutional embeddedness of economics), que, em síntese, significa que o papel da economia em cada sistema será diferente, tendo em vista as instituições que a aplicam.

Em particular, quando se examina o ilícito de abuso de posição dominante, observase que muitos dos critérios desenvolvidos nos Estados Unidos, para definir a licitude de determinadas práticas de distribuição, por exemplo, levam em consideração aspectos relacionados a ônus da prova (i.e., a quem incumbe provar qual aspecto de determinada conduta), que podem levar à conclusão pela licitude ou ilicitude de determinada conduta.

Assim, a mera transposição de teorias econômicas e padrões de licitude de um sistema para outro não teria como consequência o mesmo resultado, pois que diferenças institucionais e processuais de cada ordenamento tendem a conduzir a resultados diferentes. No Capítulo II, voltaremos a este tópico, com foco especial nos ilícitos de repressão ao abuso de posição dominante tendentes à exclusão. 


\section{CAPÍTULO II - DIREITO DA CONCORRÊNCIA, ABUSO DE POSIÇÃO DOMINANTE E CONDUTAS DE EXCLUSÃO}

\section{INTRODUÇÃO}

A repressão ao comportamento abusivo de empresas que detêm poder de mercado está presente em normas de disciplina da concorrência de diversos países. Ao tratar destas normas, VICKERS usa a terminologia de "ilícito de abuso de poder de mercado" e explica que este é geralmente considerado um dos três elementos do direito concorrencial, ao lado da repressão aos acordos anticompetitivos e do controle de operações de concentração econômica. ${ }^{111}$

O ilícito de "abuso de poder de mercado"112 é tratado na legislação comunitária europeia no artigo 102 do Tratado da CE, que trata da figura do abuso de posição dominante. ${ }^{113}$ No direito americano, o abuso de poder de mercado é tratado na Seção 2 do Sherman Act de 1890, relativo ao ilícito de monopolização e de tentativa de monopolização. Estes dois dispositivos legais são considerados pela literatura antitruste como os dois principais modelos inspiradores das regras relativas à repressão a condutas unilaterais de agentes com poder de mercado em países que buscam adotar regras semelhantes. $^{114}$

Em nosso entendimento, o modelo brasileiro alinha-se à tradição europeia, relacionada ao abuso de posição dominante, como trataremos em maior detalhe adiante. ${ }^{115}$ Como já brevemente tratado, na Lei 8.884/94, o abuso de posição dominante vem regulado pelos artigos 20 e 21 . O artigo 20 estabelece que constituem infração da ordem econômica, independentemente de culpa, os atos, sob qualquer forma manifestados, que tiverem por

\footnotetext{
${ }^{111}$ VICKERS, John. Abuse of Market Power. In: The Economic Journal, 115 (June), F244-F261, p. 244.

${ }^{112}$ Ao longo do trabalho, utilizamos, de forma geral, os termos "posição dominante" e "abuso de posição dominante"; contudo, utilizaremos o termo "poder de monopólio" e "ilícito de monopolização" quando tratarmos de aspectos específicos do direito antitruste dos Estados Unidos.

113

${ }^{114}$ HAWK, Barry E. Article 82 and Section 2: Abuse and Monopolization Conduct. In: Issues in Competition Law and Policy, Volume II, 2008, ABA Section of Antitrust Law, p. 871-893

${ }^{115}$ GONÇALVES, Priscila Brólio. Fixação e Sugestão de Preços de Revenda em Contratos de Distribuição. São Paulo: Editora Singular, 2002, p. 141. FORGIONI considera que o nosso sistema é híbrido, conforme a seguir explicado: “... o sistema da lei brasileira é um sistema híbrido, que aproveitou o europeu no que tange à caracterização do ilícito pelo objeto ou efeito, mas supera tanto esta tradição quanto aquela norteamericana no que tange à tipificação dos atos." FORGIONI, Paula A. Os Fundamentos do Antitruste. 2. ed. rev. e atual, São Paulo: Revista dos Tribunais, 2005, p. 147.
} 
objeto ou puderem produzir, entre outros efeitos, o exercício abusivo de posição dominante (inciso IV). $\mathrm{O}$ artigo 21, por sua vez, lista uma série de condutas, de forma não exaustiva, que caracterizam uma infração da ordem econômica, quando configurarem qualquer um dos incisos do artigo 20. A Lei 12.529/2011 trouxe dispositivos e abordagem muito semelhantes às da Lei 8.884/94 em seu artigo 36, com algumas pequenas diferenças, que serão tratadas em mais detalhes adiante.

Apesar de algumas diferenças de abordagem quanto aos dois modelos principais mencionados acima (modelo norte-americano e modelo europeu), que são frequentemente citadas pela literatura antitruste, questões fundamentais são compartilhadas entre eles, no que diz respeito ao tratamento de condutas unilaterais de agentes econômicos que ocupam posição dominante. Estas questões estão também presentes entre nós e são relevantes para o estudo da disciplina jurídica da concorrência e, em particular, da disciplina da repressão ao abuso de posição dominante à luz da Lei 8.884/94 e, agora, à luz da Lei 12.529/2011.

A questão principal é: como diferenciar um comportamento lícito de um agente em posição dominante de um comportamento ilícito? Qual é a linha divisória entre as condutas que podem ser adotadas por agentes econômicos que detêm posição dominante e as condutas que estes agentes não poderiam adotar? Destas questões principais, derivam outras: qual a prova que deve ser produzida na demonstração da ocorrência de um exercício abusivo de posição dominante? O que deve ser avaliado na análise da licitude de determinadas práticas?

Na última década, trabalhos doutrinários e estudos de autoridades de defesa da concorrência estrangeiras têm buscado traçar os contornos das condutas que um agente, detentor de posição dominante, pode ou não adotar, de acordo com a disciplina da concorrência. A título de exemplo, nos Estados Unidos, durante os anos de 2006 e 2007, as autoridades de defesa da concorrência promoveram debates públicos e audiências conjuntas acerca do tema de condutas unilaterais, ${ }^{116}$ não tendo chegado a um consenso sobre a forma de tratamento do tema em diversos de seus aspectos. Na Europa, em 2009, após um período de mais de três anos em consulta pública, a Comissão Europeia publicou orientações sobre

\footnotetext{
${ }^{116}$ As audiências foram conduzidas conjuntamente pela Federal Trade Commission e pelo Department of Justice. A este respeito, ver nota à imprensa disponível em http://www.justice.gov/atr/public/press_releases/2005/213369.htm, acesso em novembro de 2010.
} 
prioridades na aplicação do artigo 102 do Tratado CE a comportamentos de exclusão abusivos por parte de empresas em posição dominante (Documento sobre Abusos de Exclusão). ${ }^{117}$

A questão que se coloca - quais comportamentos de agentes econômicos com domínio de mercado devem ser coibidos - remete à difícil tarefa de conciliar objetivos, muitas vezes conflitantes, da disciplina concorrencial. ${ }^{118} \mathrm{Se}$, por um lado, o direito da concorrência busca reprimir condutas abusivas de agentes econômicos em posição de domínio de mercado, por outro lado, não pode ter o efeito de coibir comportamentos lícitos destes mesmos agentes econômicos, de forma a ter um efeito neutralizador da concorrência, ao criar uma espécie de falta de incentivo para que agentes em posição dominante concorram de forma agressiva ou por meio de inovações. ${ }^{119}$ Além disto, diversos comportamentos adotados por empresas em posição dominante têm efeitos competitivos ambíguos e podem também ter justificativas comerciais legítimas e de eficiência. ${ }^{120}$

A disciplina do abuso de posição dominante apresenta outras dificuldades em seu tratamento, que serão tratadas mais adiante. Como consectário das várias dificuldades, observa-se uma falta de previsibilidade na forma de aplicação das normas legais e, portanto,

${ }^{117}$ COMISSÃO EUROPÉIA. Comunicação da Comissão — Orientação sobre as prioridades da Comissão na aplicação do artigo 82.o do Tratado CE a comportamentos de exclusão abusivos por parte de empresas em posição dominante (2009/C 45/02) 24.2.2009. Jornal Oficial da União Européia, disponível em http://eurlex.europa.eu/LexUriServ/LexUriServ.do?uri=OJ:C:2009:045:0007:0020:PT:PDF, acesso em novembro de 2011. (Documento Europeu sobre Abusos de Exclusão)

${ }^{118}$ HAWK, Barry E. Article 82 and Section 2: Abuse and Monopolization Conduct. In: Issues in Competition Law and Policy, Volume II, 2008, ABA Section of Antitrust Law, p. 872.

${ }^{119}$ Conforme afirmado pelo Juiz Hand, em trecho citado frequentemente pela doutrina dos Estados Unidos referente ao caso Alcoa: "[T]he successful competitor having been urged to compete, must not be turned upon when he wins." United States v. Aluminum Co. of. Am., 148 F.2d 416, 427 (2d Cir., 1945). Ainda, PAGE e LOPATKA, ao tratarem da legislação norte-americana, chegam a afirmar: "Scholars and antitrust enforcers came to see that monopolization cases involve a paradox, if not an outright contradiction: they attack the conduct of firms that have succeeded in the marketplace by providing products that consumers wanted." PAGE, William H.; LOPATKA, John E. The Microsoft Case: Antitrust, High Technology, and Consumer Welfare. The University of Chicago Press, 2007, p. 5. Na mesma linha, afirma WHISH: “...the competitive process contains an inevitable paradox. Some competitors win. By being the most innovative, the most responsive to customer's wishes, and by producing goods or services in the most efficient way possible, one firm may succeed in seeing off its rivals. It would be strange, and indeed harmful, if that firm could then be condemned for being a monopolist." WHISH, Richard. Competition Law. 6th Edition, LexisNexis Buttersworths, 2008, p. 15.

120 "Much business behavior is competitively ambiguous, and courts have struggled to develop coherent principles for determining when the anticompetitive features of various practices are so pronounced as to render the behavior improper." GAVIL, Andrew I.; KOVACIC, William E.; BAKER, Jonathan B. Antitrust Law in Perspective: Cases, Concepts and Problems in Competition Policy. American Casebook Series, Thompson West, 2002, p. 584-585. 
uma incerteza quanto aos comportamentos que podem ou não ser adotados pelos agentes econômicos, impactando decisões empresariais.

Estas dificuldades se intensificam quando tratamos das estratégias de distribuição que podem ser adotadas por agentes econômicos detentores de posição dominante, objeto do Capítulo IV deste estudo. 


\section{PODER ECONÔMICO, PODER DE MERCADO E POSIÇÃO DOMINANTE}

\subsection{Introdução}

Nosso estudo trata do abuso de posição dominante; portanto, parte de situações em que a existência de domínio de mercado já estaria definida. Não é o objetivo do estudo, portanto, tratar de forma aprofundada os conceitos de poder econômico, poder de mercado ou posição dominante, termos muitas vezes utilizados como sinônimos. Para fins de melhor contextualização e compreensão do ilícito de abuso de posição dominante, entretanto, entendemos adequado fazer breves considerações acerca destes conceitos, de forma a melhor posicionar a discussão que seguirá.

\subsection{Poder econômico}

BRUNA descreve o poder econômico como uma situação que "expressa a condição de independência na tomada das decisões econômicas, ou seja, a possibilidade de se tomar decisões fora dos limites que o mercado imporia em regime concorrencial puro." Assim, para efeitos de sua disciplina jurídica, poder econômico é "a capacidade de determinar comportamentos econômicos alheios, em condições diversas daquilo que decorreria do sistema de mercado, se nele vigorasse um sistema concorrencial puro."

SALOMÃO FILHO compreende o poder econômico como elemento constitutivo do direito da concorrência, sendo que é da existência do poder econômico que se cria a necessidade e presença do direito concorrencial. ${ }^{122}$ Em linha semelhante, FORGIONI afirma que “...a repressão ao abuso do poder econômico é fenômeno que permeia todo o antitruste, na medida em que é também o fundamento da regulamentação dos acordos e das concentrações entre agentes econômicos."123

Em detalhada análise, GONÇALVES anota que, tanto nos Estados Unidos quanto na Europa, a legislação antitruste surgiu originalmente com o propósito de coibir o abuso

\footnotetext{
${ }^{121}$ BRUNA, Sérgio Varella. O poder econômico e a conceituação do abuso em seu exercício. São Paulo: Editora Revista dos Tribunais, 1997, p. 104 e seguintes.

122 "O poder econômico é o elemento constitutivo do direito concorrencial. É da existência do primeiro que se cria a necessidade de presença do último." SALOMÃO FILHO, Calixto. Recusa da contratar: disciplina jurídica. In: Regulação e Concorrência: Estudos e Pareceres, São Paulo, Malheiros, 2002, p. 137-150.

${ }^{123}$ FORGIONI, Paula A. Os Fundamentos do Antitruste. $2^{\mathrm{a}}$ ed. São Paulo: Revista dos Tribunais, 2005, p. 319.
} 
de poder econômico. ${ }^{124}$ De forma semelhante, a autora entende que a opção do legislador constitucional - tanto na Constituição Federal de 1946, que, em seu artigo 148, já estabelecia a repressão ao abuso de poder econômico, quanto no artigo 173 , parágrafo $4^{\circ}$, da Constituição Federal de 1988 - foi a de buscar controlar o poder econômico. Em sentido semelhante, FORGIONI afirma que, considerando-se o teor do artigo 173, parágrafo $4^{\circ}$, da Constituição Federal, a Lei 8.884/94 é uma lei de repressão ao abuso do poder econômico. $^{125}$

Ainda quanto ao parágrafo $4^{\circ}$ do artigo 173 da Constituição Federal de 1988 ( “a lei reprimirá o abuso do poder econômico que vise à dominação dos mercados, à eliminação da concorrência e ao aumento arbitrário de lucros"), BRUNA anota que, da própria leitura deste dispositivo, pode-se depreender que o poder econômico é tido como um dado estrutural da própria ordem econômica, que incrimina somente o abuso, deixando espaço para o exercício de tal poder de forma regular, desde que observados os ditames dessa mesma ordem econômica. ${ }^{126}$

No âmbito da disciplina da concorrência, pode-se afirmar que o poder econômico se manifesta por meio do poder no mercado. ${ }^{127}$ A seguir, portanto, teceremos breves considerações acerca do conceito de poder de mercado.

\subsection{Poder de mercado}

O poder de mercado é sabidamente um conceito chave na disciplina da concorrência. ${ }^{128} \mathrm{O}$ conceito usualmente mais adotado de poder de mercado é aquele relacionado à capacidade de um ou mais agentes econômicos aumentarem seus preços acima do nível competitivo. Nessa linha, LANDES e POSNER, em artigo de 1981, afirmam que o termo "poder de mercado" refere-se à capacidade de uma empresa (ou de

\footnotetext{
${ }^{124}$ Conforme análise feita em GONÇALVES. Priscila Brolio. A obrigatoriedade de contratar no direito antitruste. Editora Singular, 2010, p. 49.

${ }^{125}$ FORGIONI, Paula A. Os Fundamentos do Antitruste. $2^{\mathrm{a}}$ ed., São Paulo: Revista dos Tribunais, 2005, p. 269.

${ }^{126}$ BRUNA, Sérgio Varella. O poder econômico e a conceituação do abuso em seu exercício. São Paulo: Editora Revista dos Tribunais, 1997, p. 129.

${ }^{127}$ GONÇALVES. Priscila Brolio. A obrigatoriedade de contratar no direito antitruste. Editora Singular, 2010, p 48 e seguintes.

128 "The assessment of market power is and will remain a cornerstone of competition law and policy...". VICKERS, John. Market Power in Competition Cases. In: European Competition Journal, July 2006, p. 3.
} 
um grupo de empresas, agindo em conjunto) aumentar preços acima do nível competitivo sem perder vendas em uma velocidade em que o aumento de preço se tornasse não lucrativo. ${ }^{129}$

Conforme HAYES ${ }^{130}$, o conceito de poder de mercado foca-se no potencial de que consumidores venham a sofrer danos por meio de ações de um agente econômico ou um grupo de agentes econômicos que agem de forma concertada. A forma tradicional de se pensar em poder de mercado relaciona-se, de acordo com HAYES, à capacidade de um agente econômico (ou um grupo de agentes econômicos) manter preços acima de um nível competitivo. O significado de "preço" neste contexto, no entanto, poderia também ser expandido para levar em consideração outras formas de danos ao consumidor, como oferecimento de produtos/serviços a uma qualidade inferior. ${ }^{131}$

MONTI sugere quatro possíveis abordagens quando se pensa em poder de mercado, que são úteis para o panorama que aqui traçamos.

A primeira abordagem seria correspondente à abordagem neoclássica, brevemente descrita acima e que - de forma bastante resumida - considera o poder de mercado como correspondente à capacidade de aumentar preços acima de um nível competitivo. ${ }^{132}$

A segunda abordagem equipara o poder de mercado ao poder comercial que um agente econômico pode ter em relação a outros agentes econômicos; nesse caso, não estaríamos diante de poder de mercado em sentido próprio, mas diante de poder relacional. A ideia de poder relacional está intimamente ligada à discussão relativa ao abuso de

\footnotetext{
${ }^{129}$ No original: "[market power] is the ability of a firm (or a group of firms acting jointly) to raise price above the competitive level without losing many sales so rapidly that the price increase is unprofitable and must be rescinded". LANDES, William M; POSNER, Richard A.. Market Power in Antitrust Cases. In: Harvard Law Review, v. 94, March 1981, n. 5, p. 937.

${ }^{130}$ HAYS, George A. Market Power in Antitrust. In: Antitrust Law Journal, v. 60, 19992, p. 808.

${ }^{131}$ Em sentido semelhante, afirma BRUNA: "Poder econômico é não só, mas fundamentalmente, o controle sobre os preços, uma vez que a concorrência, muito embora também possa ocorrer em relação à qualidade dos produtos (concorrência não de preços ou concorrência pela qualidade), com muito maior frequência terá nos preços seu foco principal." BRUNA, Sérgio Varella. O poder econômico e a conceituação do abuso em seu exercício. São Paulo: Editora Revista dos Tribunais, 1997, p. 105.

${ }^{132}$ BISHOP e WALKER apontam que a dificuldade nesta definição consiste em identificar o que seria um "nível de preços competitivos" é praticamente impossível. BISHOP, Simon; WALKER, Mike. The Economics of EC Competition Law: Concepts, Applications and Measurement. London, Sweet \& Maxwell, 2002, p. 43.
} 
dependência econômica, que não é objeto de nosso estudo. ${ }^{133}$ MONTI esclarece, contudo, que este cenário não é usualmente visto como necessariamente correlato à disciplina da concorrência, mas aponta que o poder de mercado pode englobar o poder relacional. ${ }^{134}$

A terceira abordagem descrita por MONTI concebe o poder de mercado como a capacidade de um agente econômico excluir concorrentes ou de aumentar os seus custos. De acordo com esta abordagem, a que MONTI refere como abordagem pós-Chicago, um agente econômico teria poder de mercado quando pudesse adotar estratégias que podem prejudicar rivais e, portanto, posteriormente ter o poder de aumentar preços e reduzir a oferta. Apesar de mais ampla do que a abordagem neoclássica, esta abordagem teria o mesmo propósito, qual seja, reprimir a conduta de agentes econômicos cujas estratégias pudessem resultar em efeitos econômicos indesejáveis.

A abordagem pós-Chicago acerca de poder de mercado pode ser traçada em artigo de KRATENMAKER, LANDE e SALOP, datado de $1987^{135}$, no qual os autores propõem, em linhas gerais, que o poder de mercado pode ser exercido por intermédio de dois possíveis mecanismos: (i) aumento dos seus próprios preços e (ii) aumento dos custos dos rivais. BISHOP e WALKER explicam que estes dois mecanismos correspondem, respectivamente, ao "poder de controlar preços" e ao "poder de excluir concorrentes". Um dos motivos para se considerar o poder de mercado como "poder de excluir concorrentes" refere-se ao fato de que pode haver situações em que um agente econômico pode não

${ }^{133} \mathrm{O}$ estudo da dependência econômica e seu abuso sob a perspectiva do direito concorrencial ainda é pouco explorado no Brasil. São exceções: Calixto Salomão Filho, que trata da dependência econômica em seu Direito Concorrencial - As Condutas. Malheiros Editores, 2003; e Paula A. Forgioni, em seu Contrato de Distribuição, São Paulo: Editora Revista dos Tribunais, 2005. Em linhas gerais, mesmo não detendo posição dominante, um agente econômico pode se encontrar em situação de significativa superioridade de poder negocial em relação a determinado parceiro comercial em virtude da dependência econômica que este tem com relação àquele. Neste caso, o agente pode exercer de forma abusiva o estado de dependência econômica de seu parceiro comercial.

${ }^{134}$ Vale notar que alguns países da Europa continental possuem normas antitruste que reprimem o abuso de dependência econômica (ou abuso do estado de dependência econômica) e o consideram ilícito concorrencial específico, sendo este um importante ponto de distinção entre os diplomas concorrenciais nacionais e o direito concorrencial comunitário. Ainda, a existência de dependência econômica entre o agente dominante e seus clientes/fornecedores pode ser considerada como um dos indicativos da existência de posição dominante. WHISH trata deste indicativo ao mencionar o conceito de obligatory trading partner, explicando que a relação de dependência econômica pode ser tal que o agente dominante passa a ser um parceiro comercial obrigatório de seus fornecedores/clientes. WHISH, Richard. Competition Law. 6th Edition, LexisNexis Buttersworths, 2008, p. 186-187. Assim, no ilícito de abuso de posição dominante, a dependência econômica aparece como um dos possíveis indicativos da sua existência.

${ }^{135}$ KRATTENMAKER, Thomas G.; LANDE, Robert H.; SALOP, Steven C. Monopoly Power and Market Power in Antitrust law. In: The Georgetown Law Journal, 1987, v. 76, p. 241-269 
aparentar ter "poder sobre preços"; este mesmo agente, no entanto, pode ter a capacidade de impedir a entrada de novos agentes econômicos, de excluir rivais ou de aumentar seus custos. ${ }^{136}$ A abordagem pós-Chicago, portanto, é mais ampla do que a abordagem neoclássica mencionada anteriormente.

Finalmente, a quarta abordagem proposta por MONTI refere-se à utilização do poder de mercado como um filtro de acordo o qual testes seriam estabelecidos para definir a licitude de determinadas condutas. O poder de mercado, medido pelas participações de mercado, seria utilizado como uma base para estabelecer limites abaixo dos quais determinadas condutas seriam lícitas, de forma que agentes econômicos tivessem alguma diretriz que indicasse um nível de poder de mercado abaixo do qual determinadas condutas estariam dentro do âmbito de licitude. ${ }^{137}$ Nessa linha, como veremos adiante, o grau de poder de mercado é um dos elementos a ser levado em consideração na avaliação da existência de posição dominante.

Já quanto à mensuração do grau de poder de mercado, alguns breves comentários são necessários.

Como se sabe, o poder de mercado é geralmente avaliado com relação a um mercado relevante. $\mathrm{O}$ conceito de mercado relevante é econômico e, em muitos casos, é necessário conduzir uma análise econômica sofisticada para delinear o mercado relevante de forma apropriada. ${ }^{138}$ A operação de definição de mercado relevante é uma ferramenta de análise que tem por objetivo identificar e definir os limites de concorrência entre os agentes econômicos e as pressões competitivas às quais estão sujeitos. ${ }^{139}$

Tradicionalmente, a definição do mercado relevante leva em consideração a sua dimensão substancial/material (mercado relevante de produtos e/ou serviços) e a sua dimensão geográfica. Em linhas gerais, a definição do mercado relevante do ponto de vista

\footnotetext{
${ }^{136}$ BISHOP, Simon; WALKER, Mike. The Economics of EC Competition Law: Concepts, Applications and Measurement. London, Sweet \& Maxwell, 2002, p. 74.

${ }^{137}$ MONTI, Giorgio. EC Competition Law. Cambridge University Press, 2007, p. 125.

${ }^{138}$ WHISH, Richard. Competition Law. 5th Edition, LexisNexis Buttersworths, 2005, p. 24.

${ }^{139}$ Vale referir os termos do documento da comissão europeia acerca de definição de mercado relevante: "Market definition is a tool to identify and define the boundaries of competition between firms. It serves to establish the framework within which competition policy is applied by the Commission. The main purpose of market definition is to identify in a systematic way the competitive constraints that the undertaking s involved face." Notice on Definition of the Relevant Market for the Purposes of Community Competition Law, OJ [1997] C 372/5,
} 
do produto é feita a partir da identificação dos substitutos possíveis de determinado produto ou serviço, entre outros fatores. Em sua dimensão geográfica, o mercado relevante é definido de acordo com a área geográfica na qual o agente econômico pode exercer seu poder de mercado.

O poder de mercado detido por um determinado agente econômico é geralmente deduzido a partir do percentual de participação em um mercado relevante previamente definido. ${ }^{140}$ A participação de mercado, no entanto, é apenas uma aproximação para a avaliação de poder de mercado e, por si só, não é suficiente para que se chegue à conclusão de que um determinado agente econômico detém poder de mercado. ${ }^{141}$ Outros aspectos devem ser levados em consideração, tais como o nível de barreiras à entrada, poder de mercado dos compradores e entrantes potenciais, uma vez que estes fatores podem ter um efeito limitador do poder de mercado de um determinado agente econômico.

\subsection{Posição dominante}

Enquanto o conceito de poder de mercado tem um caráter econômico, o conceito de posição dominante tem um conteúdo jurídico. Conforme explica HAWK, o conceito de "posição dominante" é uma construção jurídica fundada em considerações de política legislativa as quais determinam a linha que deve ser traçada entre poder de mercado aceitável ou não. $^{142}$

De acordo com BRUNA, as expressões poder de mercado e posição dominante não são sinônimas. Isto porque a posição dominante é aquela que confere a seu detentor quantidade substancial de poder de mercado, a ponto de que ele possa exercer influência determinante sobre a concorrência que lhe proporcione elevado grau de independência em

\footnotetext{
${ }^{140}$ Conforme ressalta FORGIONI: “...os impactos (atuais ou potenciais) dependerão do poder de mercado da empresa ou mesmo da existência de uma posição dominante. A definição excessivamente estreita do mercado relevante, potencializando o virtual domínio, pode nos levar a conclusões equivocadas, indicando a existência de prejuízos concorrenciais que, na realidade, inexistem" FORGIONI, Paula. Os Fundamentos do Antitruste. $2^{\mathrm{a}}$ edição, São Paulo: Revista dos Tribunais, 2005, p. 446.

141 "Within the relevant market, market shares are of course relevant to an assessment of market power, although they cannot be determinative in themselves." WHISH, Richard. Competition Law. 5th Edition, LexisNexis Buttersworths, 2005, p. 43.

${ }^{142}$ No original: "...economics does not provide the means to resolve the essentially legal question whether the market power of a firm is sufficiently great to constitute a "dominant position" or "monopoly power". Like relevant market definition, "dominant position" and "monopoly power" are legal constructs based on policy considerations which suggest where the line should be drawn between acceptable market power and suspect monopoly power." HAWK, Barry E. United States, Common Market and International Antitrust: A Comparative Guide, $2^{\text {nd }}$ edition, Aspen Law \& Business, 1990, p. 788-789.
} 
relação aos demais agentes econômicos do mercado relevante. ${ }^{143}$ Ainda, citando CARVALHOSA, BRUNA explica tratar-se de posição que confere a seu titular "uma capacidade decisória que transcende às leis concorrenciais". ${ }^{144}$

Tradicionalmente, a ideia de posição dominante no direito concorrencial europeu está ligada à ideia de independência do agente econômico com relação a seus concorrentes, fornecedores, clientes e consumidores, bem como à ideia de responsabilidade especial do agente dominante.

Nos termos do Documento Europeu sobre Abusos de Exclusão, a ideia de independência do agente econômico pode ser inferida do seguinte trecho, que, de certa forma, sumariza a abordagem jurisprudencial a respeito: "a posição dominante foi definida ao abrigo da legislação comunitária, como sendo uma posição de poder econômico de que goza determinada empresa e que the permite evitar uma concorrência efectiva em determinado mercado, ao dar-lhe o poder de ter uma conduta, em larga medida, independente dos seus concorrentes, dos seus clientes e mesmo dos consumidores" (item 10). Esta noção de independência, de acordo com o referido documento, está relacionada com o "grau de pressão competitiva a que a empresa em causa está sujeita".

Quanto à ideia de responsabilidade especial, o referido documento estabelece que o agente que detém posição dominante "tem uma especial responsabilidade de não permitir que sua conduta obste uma concorrência efetiva e não falseada no mercado interno" (item 1). Ainda, o documento estabelece que "em conformidade com a jurisprudência, a detenção de uma posição dominante confere uma responsabilidade particular à empresa, cujo âmbito depende das circunstâncias concretas em apreço" (item 9).

O documento europeu reconhece, ainda, que uma posição dominante resulta de uma combinação de vários fatores que, isoladamente, não são necessariamente determinantes. Entre os fatores indicativos de posição dominante, a doutrina europeia costuma referir a existência de barreiras à entrada, superioridade tecnológica, acesso a capital (“deep

\footnotetext{
${ }^{143}$ BRUNA, Sérgio Varella. O poder econômico e a conceituação do abuso em seu exercício. São Paulo: Editora Revista dos Tribunais, 1997, p. 115.

${ }^{144}$ CARVALHOSA, Modesto. Poder Econômico e Fenomenologia, seu disciplinamento jurídico. Editora RT, 1967, p. 570, apud, BRUNA, Sérgio Varella. O poder econômico e a conceituação do abuso em seu exercício. São Paulo: Editora Revista dos Tribunais, 1997, p. 115.
} 
pocket"), acesso a insumos chave, grau de integração vertical, sistema de distribuição bem desenvolvido, entre outros. ${ }^{145}$

Em linha semelhante à abordagem europeia, FORGIONI explica que um agente em posição dominante detém poder econômico tal que lhe permite "atuar de forma independente e com indiferença à existência ou comportamento de outros agentes."146 Ainda, de acordo com a definição da autora: "a posição dominante implica sujeição (seja dos concorrentes, seja de agentes econômicos atuantes em outros mercados, seja dos consumidores) àquele que o detém. Ao revés, implica independência, absoluta liberdade de agir sem considerar a existência ou o comportamento de outros sujeitos." ${ }^{147}$ A autora explica, ainda, que um agente em posição dominante, de certa forma, fica imune a determinados riscos, podendo, inclusive, adotar uma estratégia de negócios que, se não tiver sucesso, não traz ao agente dominante prejuízos relevantes, tal qual ocorreria em um situação de um mercado competitivo. Esta posição dominante, que lhe confere independência e indiferença em relação a outros agentes, tornaria o agente dominante impermeável às leis de mercado. ${ }^{148}$

No Brasil, a Lei 8.884/94 - e agora a Lei 12.529/2011 - não pune a posição dominante em si. As duas leis estabelecem um parâmetro de acordo com o qual se presume posição dominante, a partir de participação de detida pelo agente econômico em um determinado mercado relevante, qual seja, quando um agente econômico detém $20 \%$ ou mais de um determinado mercado relevante.

Vale notar, no entanto, que houve ligeira modificação na redação dos dispositivos relativos à posição dominante, conforme a Lei 12.529/2011.

O parágrafo $2^{\circ}$ do artigo 20 da Lei 8.884/94 estabelece que "ocorre posição dominante quando uma empresa ou grupo de empresas controla parcela substancial de

\footnotetext{
${ }^{145}$ WHISH, Richard. Competition Law, 5th Edition, LexisNexis Buttersworths, 2003, p. 183 a 188. JONES, Allison; SUFFRIN, Brenda. EC Competition Law - Text, Cases and Materials, Oxford University Press, 2001, p. 310 a 316 .

${ }^{146}$ FORGIONI, Paula A. Os Fundamentos do Antitruste. $2^{\mathrm{a}}$ ed. São Paulo: Revista dos Tribunais, 2005, p. 314.

${ }^{147}$ FORGIONI, Paula A. Os Fundamentos do Antitruste. $2^{\mathrm{a}}$ ed. São Paulo: Revista dos Tribunais, 2005, p. 314.

${ }^{148}$ FORGIONI, Paula A. Os Fundamentos do Antitruste. $2^{\mathrm{a}}$ ed. São Paulo: Revista dos Tribunais, 2005, p. 316 e 318.
} 
mercado relevante, como fornecedor, intermediário, adquirente ou financiador de um produto, serviço ou tecnologia a ele relativa." Em seguida, o parágrafo $3^{\circ}$ do mesmo artigo, trata da presunção legal, conforme a seguir: "a posição dominante a que se refere o parágrafo anterior é presumida quando a empresa ou grupo de empresas controla $20 \%$ (vinte por cento) de mercado relevante, podendo este percentual ser alterado pelo CADE para setores específicos da economia."

Já o parágrafo $2^{\circ}$ do artigo 36 da 12.529/2011 estabelece: "presume-se posição dominante sempre que uma empresa ou grupo de empresas for capaz de alterar unilateral ou coordenadamente as condições de mercado ou quando controlar $20 \%$ (vinte por cento) ou mais do mercado relevante, podendo este percentual ser alterado pelo Cade para setores específicos da economia." A presunção da posição dominante, portanto, é combinada, em um mesmo dispositivo, como ocorrendo quando "uma empresa ou grupo de empresas for capaz de alterar unilateral ou coordenadamente as condições de mercado" ou "quando controlar $20 \%$ (vinte por cento) ou mais do mercado relevante."

Em termos práticos, salvo melhor juízo, parece-nos que a alteração legislativa não modifica essencialmente a definição acerca da presunção de posição dominante, pois que, sua conceituação continuará a levar em conta outros aspectos, que não somente a participação de mercado. 


\section{INTRODUÇÃO ÀS CONDUTAS DE EXCLUSÃO}

\subsection{Introdução}

O objeto deste estudo refere-se aos ilícitos de abuso de posição dominante tendentes à exclusão e, em particular, às estratégias de distribuição adotadas por agentes econômicos que podem ter efeitos de exclusão (detalhadas no próximo capítulo). Para melhor delimitação e compreensão do objeto do estudo, entendemos adequado tecer algumas considerações e traçar algumas distinções necessárias ao entendimento das condutas de exclusão.

Com este propósito, inicialmente teceremos breves comentários acerca da relação entre exclusão e colusão. Em seguida, buscaremos traçar uma distinção entre os ilícitos de exclusão e de exploração, distinção um pouco controversa, mas relevante, tendo em vista as discussões a respeito do abuso de posição dominante na Europa e que também tem alguma relevância para o direito brasileiro. Finalmente, trataremos da distinção entre os abusos de exclusão praticados por mais de um agente econômico (abusos de exclusão multilaterais ou coordenados), de um lado, e os abusos de exclusão praticados por um agente econômico de forma unilateral, de outro lado.

\subsection{Relação entre exclusão e colusão}

SALOP explica que existem duas categorias de condutas anticompetitivas: as condutas de colusão e as condutas de exclusão. A colusão envolve, por um lado, um grupo de agentes econômicos cooperando entre si para restringir sua própria oferta. As condutas de exclusão, por outro lado, envolveriam um agente econômico (ou um grupo de agentes econômicos) que aumentam seus custos ou reduzem os lucros dos concorrentes para induzir concorrentes a aumentar seus preços, reduzir a oferta ou sair do mercado. Tanto as práticas de colusão quanto as de exclusão, podem fazer que um agente econômico (ou um grupo de agentes econômicos) aumente o seu poder de mercado. ${ }^{149}$

Em linha semelhante, BAKER afirma que comportamentos anticoncorrenciais podem ser divididos em duas categorias, de acordo com a natureza dos seus efeitos, quais sejam, efeitos de colusão ou efeitos de exclusão. De forma geral, por um lado, pode-se

\footnotetext{
${ }^{149}$ SALOP, Steven C. Exclusionary Conduct, Effect on Consumers, and the Flawed Profit-Sacrifice Standard. In: Antitrust Law Journal, v. 73, n. 2, 2006, p. 311.
} 
dizer que efeitos de colusão diretamente impactam a concorrência e envolvem ações coordenadas entre concorrentes que buscam "imitar" o comportamento de um monopolista, ao restringir a oferta e aumentar o preço. Estes seriam os casos, por exemplo, dos cartéis de fixação de preços. Os efeitos de tais comportamentos são diretos, quais sejam, redução da oferta e aumento de preços, e impactam mecanismos de mercado para determinar oferta, preço, qualidade de produtos ou serviços e inovação. ${ }^{150}$

Os efeitos de exclusão, por outro lado, aumentam os custos dos rivais, ao impedir o seu acesso a insumos chave ou limitar seu acesso a canais importantes de distribuição. Os efeitos de exclusão podem resultar de atos unilaterais ou multilaterais e seus efeitos serão sempre indiretos. Ao excluir um rival ou aumentar seus custos, um agente dominante pode influenciar alguma dimensão da concorrência. O efeito direto de comportamentos de exclusão tem um impacto em um ou mais concorrentes. Assim, na síntese de BAKER, agentes econômicos podem impactar o funcionamento dos mercados direta ou indiretamente por meio de condutas que produzem efeitos de colusão e de exclusão, respectivamente.

\subsection{Exclusão vs. exploração}

Ao tratar do ilícito de abuso de posição dominante, a doutrina europeia costuma fazer uma diferenciação entre abusos de exclusão e abusos de exploração. Esta classificação não tem relevância para o modelo norte-americano, como veremos adiante, e seu sentido, mesmo nos sistemas que a adotam, é questionado pela literatura antitruste.

Conforme explica GERBER, a repressão ao abuso de exploração tem o objetivo de evitar que um agente que ocupa posição dominante explore outros agentes econômicos, quando, por exemplo, o agente dominante aumenta preços acima de um nível que um mercado competitivo permitiria. ${ }^{151}$ PARDOLESI e ARNAUDO explicam que abusos de exploração podem ser definidos como tentativas de um agente dominante em usar as oportunidades criadas pelo seu poder de mercado, para prejudicar diretamente consumidores, sendo que os preços excessivos seriam o principal exemplo deste tipo de

\footnotetext{
${ }^{150}$ BAKER, Jonathan B.. Preserving a Political Bargain: The Political Economy of the Non-Interventionist Challenge to Monopolization Enforcement. In: Antitrust Law Journal, v. 76, Issue 3, 2010, p. 605.

${ }^{151}$ GERBER, David J. Law and the Abuse of Economic Power in Europe. In: Tulane Law Review, v. 62, 1987-1988, p. 74.
} 
abuso. ${ }^{152}$ Na mesma linha, MOTTA e DE STREEL conceituam abusos de exploração como uma exploração direta de poder de mercado. ${ }^{153}$

No direito comunitário europeu, abusos de exploração são previstos no artigo 102 do Tratado da CE, mesmo dispositivo aplicável a abusos de exclusão. VAN BAEL e BELLIS observam que alguns exemplos de abuso, listados no artigo 102 do Tratado CE, referem-se a casos em que o abuso diretamente explora fornecedores ou compradores, sendo, portanto, historicamente o foco do artigo 102. Este seria o caso do artigo 102 (a) que trata da conduta de "direta ou indiretamente impor preços de compra ou de venda injustos ou outras condições injustas de comércio" ("directly or indirectly imposing unfair purchase or selling prices or other unfair trading conditions"). Este item envolveria obter vantagens indevidas de fornecedores, ao usar uma posição de domínio de mercado para cobrar preços excessivos ou impor termos injustos ou onerosos aos compradores ou consumidores.

Como observam VAN BAEL e BELLIS o conceito de abuso mais frequentemente citado por decisões e autores europeus é o que foi utilizado pela Corte de Justiça Europeia no caso Hoffmann-La Roche v. Commission, que praticamente ignora o fato de que abusos de exploração são também cobertos por este artigo. ${ }^{154}$ Diversos autores europeus observam,

\footnotetext{
${ }^{152}$ PARDOLESI, Roberto e ARNAUDO, Luca. Single-Firm Conduct: a Discipline in Search of Itself (Try it with Google)? Trabalho desenvolvido a partir de um ensaio escrito por Roberto Pardolesi e publicado em Mercato concorrenza regole, 2009, 475, com o nome de Condotta unilaterale d'impresa: uma disciplina in cerca d'identità. Disponível em http://papers.ssrn.com/sol3/papers.cfm?abstract id=1541928, acesso em novembro de 2011.

${ }^{153}$ MOTTA, Maximo e DE STREEL, Alexandre. Exploitative and Exclusionary Excessive Prices in EU Law. Trabalho apresentado na $8^{\text {th }}$ Annual European Union Competition Workshop, Florença, 2003, p. 1, disponível

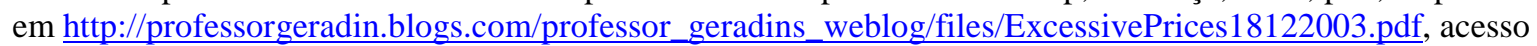
em Novembro de 2010.

${ }^{154}$ VAN BAEL, Ivo V.; BELLIS, Jean-François. Competition Law of the European Community. 4th Edition, Kluwer Law International, 2005, p. 904-905. Os autores referem-se a passagem da decisão da Corte de Justiça no caso Hoffmann-La Roche v. Commission, a seguir transcrita: "The concept of an abuse is an objective concept relating to the behaviour of an undertaking in a dominant position which is such as to influence the structure of a market where, as a result of the very presence of the undertaking in question, the degree of competition is weakened and which, through recourse to methods different from those which condition normal competition in products or services on the basis of the transactions of commercial operators, has the effect of hindering the maintenance of the degree of competition still existing in the market or the growth of that competition." Hoffmann-La Roche v. Commission, [1979] ECR 461, parágrafo 91.
} 
ainda, que o artigo 102 do Tratado CE tem sido aplicado com mais frequência a abusos de exclusão. $^{155}$

WHISH explica que, apesar de a distinção entre abusos de exploração e abusos de exclusão ser útil ao estudo do artigo 102 do Tratado da $\mathrm{CE}$, não há uma demarcação rígida entre estas duas categorias, uma vez que um mesmo comportamento pode ter características que o qualificariam como de exploração e de exclusão. Como exemplo, explica que um agente econômico que aplica preços discriminatórios explora sua posição, ao obter um lucro máximo às custas de seus compradores (ou consumidores) e pode, ao mesmo tempo, adotar uma conduta de exclusão, ao tornar mais difícil para outros agentes econômicos ter acesso a um determinado mercado. Da mesma forma, uma recusa de venda pode ter um propósito de exploração - por exemplo, quando é adotada com o objetivo de fazer um comprador pagar um preço maior para um determinado produto ou serviço - e, ao mesmo tempo, ter um caráter de exclusão - quando tem o efeito potencial de excluir concorrentes do mercado. ${ }^{156}$ Práticas de exclusão, portanto, podem ser indiretamente exploratórias de consumidores e alguns autores argumentam, ainda, que nenhuma conduta poderia ser propriamente caracterizada como de exclusão se não for, ao final, exploratória. ${ }^{157}$

Como já dito, abusos de exploração não fazem parte do repertório da disciplina concorrencial dos Estados Unidos ${ }^{158}$, sendo uma categoria tipicamente europeia, apesar de também presente em outros diplomas concorrenciais.

Entre os diplomas concorrenciais em que se verifica a possibilidade de abusos de exploração está a própria Lei 8.884/94 - e, também, a Lei 12.529/2011. O inciso XXIV do artigo 21 da Lei 8.884/94 estabelece entre as condutas que podem caracterizar uma infração à ordem econômica a imposição de preços excessivos, ou o aumento sem justa causa de preço de bem ou serviço. Ainda, o inciso III do artigo 20 da Lei 8.884/94 estabelece o

\footnotetext{
${ }^{155}$ BISHOP, Simon; WALKER, Mike. The Economics of EC Competition Law: Concepts, Applications and Measurement. London, Sweet \& Maxwell, 2002, p. 74.

${ }^{156}$ WHISH, Richard. Competition Law. 6th Edition, Oxford, 2009, p. 199.

${ }^{157}$ VICKERS, John. Abuse of Market Power. In: Economic Journal, v. 115, n. 504, June 2005, p. 246.

${ }^{158}$ CARLTON e HEYER afirmam sobre a disciplina antitruste dos Estados Unidos: "even firms with considerable market power are generally permitted by antitrust law to engage in simple monopoly pricing. In jurisdictions other than the United States, the principle is not always followed." CARLTON, Dennis W; HEYER, Ken. Antitrust Policy TowardsSingle-Firm Conduct. Economic Analysis Group Discussion Paper, Março 2008, p. 2, disponível em http://www.justice.gov/atr/public/eag/231610.pdf, acesso em novembro de 2011.
} 
aumento arbitrário de lucros como um dos efeitos (ainda que potencial) que, caso resultante de determinada conduta, configuraria uma infração à ordem econômica. Este dispositivo tem sido fonte de controvérsia doutrinária e jurisprudencial. ${ }^{159}$

Vale notar que a Lei 12.529/2011, em seu artigo 36, parágrafo $3^{\circ}$ (equivalente ao artigo 21 da Lei 8.884/94) deixou de incluir entre as condutas que podem configurar hipótese de infração à ordem econômica os preços excessivos. Não obstante, o artigo 36, inciso III, manteve o aumento arbitrário de lucros como efeito (ainda que potencial) que, caso resultante de determinado comportamento, configuraria um ato como infração à ordem econômica. Além disto, lembremos que o rol do parágrafo $3^{\circ}$ do artigo 36 é meramente exemplificativo (não exaustivo), o que nos leva a entender que, em princípio, permanece possível argumentar que o ilícito de preços excessivos ainda está coberto pela Lei $12.529 / 2011$.

\subsection{Abusos de exclusão multilaterais ou coordenados vs. abusos unilaterais de exclusão}

As condutas de exclusão podem ser classificadas como unilaterais ou multilaterais (ou coordenadas). Agentes econômicos podem atuar de forma independente ou em conjunto com outros agentes econômicos.

Agentes econômicos agem de forma unilateral a maior parte do tempo. Eles adotam decisões comerciais acerca de como organizar e escoar sua produção, como estruturar sua oferta, determinar preços, o quanto pretendem inovar, adicionar ou remover um produto de sua linha de produtos/serviços e se devem distribuir seus produtos diretamente ou por agentes econômicos independentes. Tais comportamentos são, em princípio, legítimos, mesmo quando praticados por agentes econômicos que detêm posição dominante. ${ }^{160}$

\footnotetext{
159 A este respeito, ver comentários de FORGIONI. FORGIONI, Paula A. Os Fundamentos do Antitruste. $2^{\mathrm{a}}$ ed. São Paulo: Revista dos Tribunais, 2005, p. 353 e seguintes. Conforme recente artigo de RAGAZZO, não há registro, no Brasil, de condenação por prática de preço excessivo, não obstante o fato de que várias denúncias foram apresentadas ao SBDC. RAGAZZO, Carlos Emmanuel Joppert. Preço Abusivo, Eficácia Jurídica e Análise Econômica. Revista do IBRAC, Direito da Concorrência, Consumo e Comércio Internacional, Ano 18, Vol. 19, jan-jun-2011, p. 23.

160 "Unilateral conduct is ubiquitous. Firms act unilaterally most of the time: they determine their own output and set prices, and decide how much to innovate, whether to add or remove a product from their line, and whether to distribute on their own or through independent dealers. None of this behavior is even presumptively suspicious, and the costs of monitoring every unilateral act, even by dominant firms, would be extraordinarily high, for both government observation and the chill it would place on innovation and
} 
Pode-se afirmar que há um razoável consenso acerca da forma de tratamento das condutas multilaterais, envolvendo acordos entre agentes econômicos situados na mesma etapa da cadeia de produção, em particular, quando se trata de cartéis. O mesmo consenso, no entanto, não se verifica no tratamento das chamadas condutas unilaterais. A teoria econômica aplicada ao antitruste é praticamente unânime quanto ao entendimento acerca dos efeitos deletérios dos cartéis. Quanto aos efeitos e possíveis virtudes dos comportamentos de agentes com domínio de mercado, no entanto, não há consenso acerca de uma série de comportamentos que podem ser adotados por estes agentes. ${ }^{161}$

Ainda acerca da classificação de condutas de exclusão em unilaterais e coordenadas, vale conferir a explicação de GAVIL, KOVACIC e BAKER.${ }^{162}$ Conforme explicam os autores, um agente econômico que detém poder de mercado pode adotar, de forma unilateral, diversos tipos de estratégias comerciais tendentes à exclusão de seus rivais. Algumas condutas, no entanto, exigem a participação (voluntária ou involuntária) de outros agentes econômicos (condutas coordenadas de exclusão). Quando mais de um agente econômico participa em uma estratégia de exclusão (conduta coordenada de exclusão), esta conduta pode ser categorizada como horizontal - quando envolver um acordo entre concorrentes - ou vertical - quando envolver um agente econômico e um fornecedor ou um cliente/comprador deste agente econômico. Enquanto as condutas unilaterais de exclusão pressupõem que o agente que pratica o abuso ocupa posição dominante, tal pressuposto não seria essencial, de acordo com os autores, nos casos de condutas coordenadas de exclusão.

GAVIL, KOVACIC e BAKER utilizam como exemplo de conduta coordenada horizontal de exclusão os chamados boicotes conjuntos ( group boycotts), também referidos como recusa de negociação concertada (concerted refusal to deal), que consistem em acordos entre concorrentes que têm por objetivo excluir rivais (dos agentes econômicos parte do acordo). Um grupo de concorrentes pode, por exemplo, agir de forma coordenada

competition." HOVENKAMP, Herbert. The Antitrust Enterprise. Principles and Execution. Harvard University Press. 2005, p. 109.

${ }^{161}$ A este respeito, ver CAMPBELL e ROWLEY: "Unlike cartels, where there is almost universal acceptance that certain types of naked agreements in restraint of trade have no redeeming social value, the economic thinking related to monopolization and dominance is complex and continues to evolve". CAMPBELL, A. Neil and ROWLEY, J. William. The Internationalization of Unilateral Conduct Laws - Conflict, Comity, Cooperation and/or Convergence? In: Antitrust Law Journal, v. 75, Issue 2 (2008), p. 272.

${ }^{162}$ GAVIL, Andrew I.; KOVACIC, William E.; BAKER, Jonathan B. Antitrust Law in Perspective: Cases, Concepts and Problems in Competition Policy. American Casebook Series, Thompson West, 2002, p. 681. 
e requerer que um fornecedor deixe de fornecer a um rival, com o objetivo de dificultar o desenvolvimento de sua atividade e, possivelmente, excluí-lo do mercado ou criar dificuldades para que ele permaneça no mercado ao aumentar seus custos. ${ }^{163}$

Interessante notar que, nos Estados Unidos, HOVENKAMP observa que é difícil identificar a primeira decisão da Suprema Corte que tratasse precipuamente de condutas unilaterais de exclusão, uma vez que os primeiros casos decididos, acerca de condutas de exclusão, envolviam alguma forma de comportamento colaborativo. ${ }^{164}$ Nesse sentido, HOVENKAMP aponta que a primeira decisão da Suprema Corte dos Estados Unidos envolvendo uma conduta de exclusão tratava de uma conduta multilateral de exclusão, datada de 1904, relativa ao caso Montague \& Co. v. Lowry. A decisão condenou um acordo entre uma associação de comerciantes de telhas que teriam combinado não adquirir telhas de fornecedores que não fossem membros da associação e, ainda, que exigiam que os fornecedores que faziam parte da associação vendessem telhas aos não-membros apenas a um determinado preço. Os comerciantes de telha estariam provavelmente em colusão e pressionando os fornecedores a aumentar os custos dos comerciantes rivais.

A primeira decisão da Suprema Corte dos Estados Unidos, que envolvia alegações de conduta unilateral de exclusão e que tratou da questão no mérito, seria a decisão proferida no caso Standard Oil Co of New Jersey v. United States, datada de 1911, que decidiu que a consolidação de uma empresa grande com empresas menores, controladas pelos mesmos acionistas, constituiria uma restrição ao comércio e uma tentativa de monopolização. A esta decisão seguiram-se várias outras e, mais recentemente, os ilícitos de monopolização têm se focado em mercados de alta tecnologia.

\footnotetext{
${ }^{163}$ GAVIL, Andrew I.; KOVACIC, William E.; BAKER, Jonathan B. Antitrust Law in Perspective: Cases, Concepts and Problems in Competition Policy. American Casebook Series, Thompson West, 2002, p. 681; HOVENKAMP, Herbert. Exclusion and the Sherman Act. In: University of Chicago Law Review, v. 72, 2005, p. 147. ("Both Section 1 and 2 of the Sherman Act prohibit anticompetitive exclusion from markets. Section 2 condemns the exclusionary practices of a single firm. Section 1 condemns exclusionary conduct under the rubric of boycotts or concerted refusal to deal, including predatory acts against the rivals of a cartel or joint venture, as well as tying and exclusive dealing.")

${ }^{164}$ HOVENKAMP, Herbert. Exclusion and the Sherman Act. In: University of Chicago Law Review, v. 72, 2005, p. 147.
} 


\section{PANORAMA da disciplina de REPRESSÃo AO ABUSO de POSIÇÃo DOMINANTE: OS ABUSOS DE EXCLUSÃO}

\subsection{Introdução}

Como já dito, os sistemas de repressão ao abuso de posição dominante, adotados pelo direito antitruste dos Estados Unidos e pelo direito concorrencial comunitário europeu, são considerados pela literatura antitruste como os dois principais modelos inspiradores das regras relativas à repressão a condutas unilaterais de agentes detentores de posição dominante.

Conforme explica GERBER ${ }^{165}$, as abordagens e os mecanismos utilizados por cada sistema compartilham uma mesma preocupação ou um mesmo objetivo: buscar proteger a sociedade contra os males que podem resultar do uso do poder econômico, sem restringir de forma indevida as condutas de agentes econômicos que detenham posição dominante. GERBER, no entanto, ressalta que os sistemas são fundamentalmente diferentes: eles evoluíram a partir de diferentes origens conceituais e teóricas; estão enraizados em diferentes tradições jurídicas; são moldados por diferentes pressões sociais e políticas; e sua aplicação (enforcement) é fundamentada em diferentes premissas acerca do direito e da teoria econômica.

A constante referência na doutrina e jurisprudência administrativa brasileiras aos dois modelos e, ainda, o fato de que a experiência com as normas relativas à disciplina do abuso de posição dominante nos dois sistemas ser mais antiga do que a brasileira, sugere que sua análise pode servir de referencial útil ao estudo da disciplina no Brasil. Assim, nos próximos tópicos, buscaremos fazer uma breve descrição dos dois modelos, seguida de uma comparação entre eles, para, finalmente, tratar do abuso de posição dominante nos termos da legislação brasileira.

\subsection{Repressão ao ilícito de monopolização nos Estados Unidos}

Nos Estados Unidos, o ilícito de abuso de poder de mercado por um agente econômico está regulado pela Seção 2 do Sherman Act, de 1890, que trata dos chamados

\footnotetext{
${ }^{165}$ GERBER, David J. Law and the Abuse of Economic Power in Europe. In: Tulane Law Review, v. 62, 1987-1988, p. 58.
} 
ilícitos de monopolização ou tentativas de monopolização. ${ }^{166}$ Para os fins deste estudo, interessa-nos particularmente o ilícito de monopolização.

A Seção 2 não proíbe o monopólio em si mesmo, mas busca impedir a "monopolização" e as "tentativas de monopolização". 167 GAVIL, KOVACIC e BAKER explicam que o termo "monopolização" demonstra uma preocupação não somente com a situação de "monopólio", mas em como um agente econômico obtém ou protege uma posição de monopólio. ${ }^{168}$

Conforme aponta HOVENKAMP ${ }^{169}$, o ilícito de monopolização é, dentre os ilícitos concorrenciais previstos no direito norte-americano, aquele cuja definição é menos clara. A Seção 2 não explicita o que significa "monopolização", e a história da common law não ajudaria nesta interpretação, não havendo, desta forma, uma origem no sistema de common law para este tipo de ilícito. KOVACIC e SHAPIRO observam que, nas primeiras décadas de vigência do Sherman Act, os tribunais norte-americanos já tinham dificuldade em definir o ilícito de monopolização. ${ }^{170}$ HOVENKAMP, em artigo mais recente, chega a afirmar que determinadas questões conceituais relativas ao ilícito de monopolização provavelmente

\footnotetext{
${ }^{166}$ Seção 2 do Sherman Act: "Every person who shall monopolize, or attempt to monopolize, or combine or conspire with any other person or persons, to monopolize any part of the trade or commerce among the several States, or with foreign nations, shall be guilty of a felony."

${ }^{167}$ GELLHORN, E.; KOVACIC, W. E.; CALKINS, S. Antitrust Law and Economics in a Nutshell. 5th Edition, Thomson West, 2004, p. 26.

168 "Use of the term "monopolization" indicates legislative concern not with the status of monopoly alone, but rather with how a firm obtains or protects a commanding commercial position." GAVIL, Andrew I; KOVACIC, William E.; BAKER, Jonathan B. Antitrust Law in Perspective: Cases, Concepts and Problems in Competition Policy. American Casebook Series, Thompson West, Second Edition, 2008. P. 598

${ }^{169}$ HOVENKAMP, Herbert. The Antitrust Enterprise. Principles and Execution. Harvard University Press. 2005, p. 150. Em sentido semelhante, aponta BAKER: “...the antitrust norms against cartel behavior (collusion) are broadly accepted, while the norms governing exclusion are disputed. Most notably, the antitrust prohibition against monopolization, Sherman Act Section 2, is contested terrain." BAKER, Jonathan B.. Preserving a Political Bargain: The Political Economy of the Non-Interventionist Challenge to Monopolization Enforcement. In: Antitrust Law Journal, v. 76, n. 3, 2010, p. 605.

${ }^{170}$ Conforme os autores: "As the courts delineated rules for collusion and cooperation between firms, they struggled in these early years to come to grips with monopoly. The Sherman Act's language and legislative history indicated that Congress did not condemn the status of monopoly. Instead, the crucial initial analytical task for courts was to define the sorts of behavior which, when coupled with monopoly power, constituted illegal monopolization." KOVACIC, William; SHAPIRO, Carl. Antitrust Policy; A Century of Economic and Legal Thinking. In: Journal of Economic Perspectives, V. 14, no. 1, Winter 2000, p. 45.
} 
jamais serão solucionadas, entendo em vista a natureza aberta da redação da Seção 2 do Sherman Act. ${ }^{171}$

Conforme aponta HOVENKAMP, ainda, o escopo e o significado de condutas de exclusão nos termos do Sherman Act permanecem fracamente definidos. Não há uma formulação generalizada de condutas de exclusão unilaterais ou multilaterais que tenham uma aceitação universal. Ainda, nas palavras do autor, o melhor que o antitruste foi capaz de produzir foram regras para classes específicas de condutas, tais como regras de custo envolvendo preços predatórios, ou, no caso das condutas multilaterais, regras simples de ilegalidade per se. ${ }^{172}$

Em sentido semelhante, ELHAUGE afirma que a doutrina acerca do ilícito de monopolização tem utilizado padrões vazios de análise e rótulos conclusivos que oferecem diretrizes desprovidas de significado e que, portanto, não oferecem orientações acerca de quais condutas seriam consideradas como ilícitos de exclusão. ${ }^{173}$

Possivelmente, a definição de condutas de exclusão mais aceita entre os autores norte-americanos é a proposta no tratado de AREEDA e HOVENKAMP. Os autores propõem uma definição de condutas de exclusão de acordo com a qual estas seriam atos razoavelmente capazes de criar, aumentar ou prolongar poder de monopólio ao prejudicar as oportunidades de rivais, que, (i) ou não beneficiam consumidores, (ii) ou são desnecessários para os benefícios ao consumidor que os atos produzem, (iii) ou produzem prejuízos que são desproporcionais aos benefícios resultantes. ${ }^{174}$

Apesar das tentativas de definir as condutas unilaterais de exclusão (que, nos Estados Unidos, se identificam com os próprios ilícitos de monopolização, por não haver o equivalente a abusos unilaterais de exploração), de forma geral, a literatura norte-americana

\footnotetext{
${ }^{171}$ HOVENKAMP, Herbert. The Harvard and Chicago School and the Dominant Firm. In: PITOFSKY, Robert (Ed.). How the Chicago School Overshot the Mark. The Effect of Conservative Economic Analysis of U.S. Antitrust, Oxford University Press, 2008, p. 118.

${ }^{172}$ HOVENKAMP, Herbert. Exclusion and the Sherman Act. In: University of Chicago Law Review, v. 72, 2005, p. 148.

${ }^{173}$ Nas palavras de ELHAUGE: “...monopolization doctrine currently uses vacuous standards and conclusionary labels that provide no meaningful guidance about which conduct will be condemned as exclusionary”. ELHAUGE, Einer. Defining Better Monopolization Standards. In: Stanford Law Review, v. 56, Novembro de 2003, p. 253.

${ }^{174}$ AREEDA, Phillip E.; HOVENKAMP, Herbert. Antitrust Law: An Analysis of Antitrust Principles and Their Applications. Aspen, $2^{\text {nd }}$ edition, 2002, p. 72.
} 
acerca dos ilícitos de monopolização tende a concordar que há um estado de confusão sobre seu conceito.

Este "estado de confusão" pode ser ilustrado pelo debate e a divergência pública entre as duas autoridades de defesa da concorrência dos Estados Unidos, a Federal Trade Commission e o Department of Justice. Como já mencionado, durante os anos de 2006 e 2007, as duas agências conduziram audiências conjuntas acerca da aplicação da Seção 2 do Sherman Act, tendo recebido diversas contribuições. As duas autoridades, no entanto, não chegaram a um consenso sobre as conclusões. Em setembro de 2008, o Department of Justice publicou um relatório acerca do tema ${ }^{175}$, que não foi acolhido pela Federal Trade Commission. Alguns meses depois, o Department of Justice publicamente repudiou o relatório e declarou sua intenção de revigorar a aplicação da Seção 2 do Sherman Act. ${ }^{176}$

BAKER observa que a controvérsia e disputa entre os dois órgãos de defesa da concorrência norte-americanos em torno do tema de monopolização é curiosa, tendo em vista o fato de que o governo norte-americano raramente inicia casos envolvendo condutas de monopolização. ${ }^{177}$ BAKER anota que muitos dos casos recentes sobre monopolização são originários de ações ajuizadas por particulares, o que, como já mencionado, é uma característica particular e marcante do antitruste norte-americano.

Outro exemplo acerca da falta de consenso nos Estados Unidos acerca do ilícito de monopolização envolveu o conhecido caso envolvendo a Microsoft, iniciado pelo Department of Justice em 1998 e concluído por acordo em 2001. Conforme aponta BAKER, o mérito do caso e a discussão subjacente acerca do papel do ilícito de monopolização, previsto na Seção 2 do Sherman Act, continuam a ser debatidos por diversos autores. ${ }^{178}$

\footnotetext{
${ }^{175}$ United States Department of Justice. Competition and Monopoly: Single-Firm Conduct under Section 2 of the Sherman Act. Setembro de 2008, disponível em http://www.justice.gov/atr/public/reports/236681.pdf, acesso em novembro de 2011.

${ }^{176}$ Neste sentido, ver notícia à imprensa, datada de 11 de maio de 2009. United States Department of Justice. Justice Department Withdraws Report on Antitrust Monopoly Law, disponível em http://www.justice.gov/atr/public/press_releases/2009/245710.htm, acesso em novembro de 2010.

${ }^{177}$ Conforme texto publicado em 2010, BAKER aponta que, desde 1977, a média de casos de monpolização iniciados pela Federal Trade Commission e pelo Department of Justice foi de 1 (um) caso por agência, por ano. BAKER, Jonathan B.. Preserving a Political Bargain: The Political Economy of the Non-Interventionist Challenge to Monopolization Enforcement. In: Antitrust Law Journal, v. 76, Issue 3, 2010, p. 607.

${ }^{178}$ BAKER, Jonathan B. Preserving a Political Bargain: The Political Economy of the Non-Interventionist Challenge to Monopolization Enforcement. In: Antitrust Law Journal, v. 76, Issue 3, 2010, p. 607. Para uma
} 
Conforme observa KOVACIC, um exame da experiência norte-americana acerca de comportamentos de empresas dominantes indica mudanças significativas ao longo do tempo. A partir da década de 1980, desenvolvimentos na teoria e na política antitruste teriam reduzido o escopo de condutas de empresas dominantes que seriam consideradas ilícitas. ${ }^{179}$ Um exame dos desenvolvimentos teóricos que influenciaram a abordagem das autoridades antitruste norte-americana quanto a condutas de exclusão será traçado em maiores detalhes no Capítulo III.

análise aprofundada e crítica acerca do caso, ver PAGE, William H.; LOPATKA, John E. The Microsoft Case: Antitrust, High Technology, and Consumer Welfare. The University of Chicago Press, 2007.

${ }^{179}$ KOVACIC, William. The Intelectual DNA of Modern U.S. Competition Law for Dominant Firm Conduct: The Chicago/Harvard Double Helix. In: Columbia Business Law Review, V. 1, 2007, p. 3. 


\subsection{Direito comunitário europeu: o artigo 102 do Tratado $C E$}

No direito comunitário europeu, o ilícito de abuso de posição dominante vem disciplinado no artigo 102 do Tratado CE. ${ }^{180} \mathrm{O}$ artigo 102 contém uma seção geral, que proíbe o abuso de posição dominante, seguida de uma lista não exaustiva de exemplos de comportamentos que podem configurar abuso. MONTI afirma que a redação do artigo 102 pode cobrir uma ampla gama de comportamentos empresariais e permite um razoável campo de discricionariedade por parte das autoridades decisórias, podendo ser aplicada com alguma flexibilidade quanto aos tipos de objetivos perseguidos. ${ }^{181}$

Diversos autores identificam as origens intelectuais do artigo 102 do Tratado CE na Escola Ordoliberal de Freiburg, cujos estudos foram desenvolvidos nas décadas de 1920 e 1930. ${ }^{182}$ Descrita por DEVLIN e JACOBS como "uma abordagem filosófica relativamente obscura acerca da concorrência" ${ }^{183}$, a Escola Ordoliberal de Freiburg teria tido um papel importante no desenvolvimento da disciplina da concorrência no direito comunitário europeu e, em particular, em relação à disciplina do abuso de posição dominante. ${ }^{184}$

\footnotetext{
${ }^{180}$ Conforme Artigo 102 do Tratado CE: "É incompatível com o mercado interno e proibido, na medida em que tal seja susceptível de afectar o comércio entre os Estados-Membros, o facto de uma ou mais empresas explorarem de forma abusiva uma posição dominante no mercado interno ou numa parte substancial deste. Estas práticas abusivas podem, nomeadamente, consistir em: a) Impor, de forma directa ou indirecta, preços de compra ou de venda ou outras condições de transacção não equitativas; b) Limitar a produção, a distribuição ou o desenvolvimento técnico em prejuízo dos consumidores; c) Aplicar, relativamente a parceiros comerciais, condições desiguais no caso de prestações equivalentes colocando-os, por esse facto, em desvantagem na concorrência; d) Subordinar a celebração de contratos à aceitação, por parte dos outros contraentes, de prestações suplementares que, pela sua natureza ou de acordo com os usos comerciais, não têm ligação com o objecto desses contratos."

${ }^{181}$ MONTI, Giorgio. EC Competition Law. Cambridge University Press, 2007, p. 160.

${ }^{182}$ VICKERS, John. Abuse of Market Power. In: The Economic Journal, 115 (June), F244-F261, p. 246.

${ }^{183}$ DEVLIN, Alan; JACOBS, Michael. Microsoft's Five Fatal Flaws. In: Columbia Business Law Review, v. 2009, n. 1, p. 92.

${ }^{184}$ Neste sentido, afirma GERBER: “Ordoliberal thought has also played a major role in the development of Community competition law." Ainda, com relação ao ilicito de abuso de posição dominante: "Interpretation and application of the concept of abuse of a market-dominating position often reflects, for example, the influence of German legal developments." GERBER, David. Constitutionalizing the Economy: German NeoLiberalism, Competition Law and the "New" Europe. In: American Journal of Competition Law, v. 42, 1994, p. 73-74. Vale notar que, em 2007, o então Diretor Geral da DG Competition, Philip Lowe, reconheceu a influência da Escola Ordoliberal na prática decisória da Comissão Europeia conforme a seguinte declaração: "The case-law of the European Courts and also the decisional practice of the Commission were initially influenced by ordoliberal thought which has its origin in the so-called Freiburg School. Their members advocated a strict legal framework and a strong role for the state in protecting the basic parameters of competition. Competition was understood as process of economic coordination on the basis of freedom of action. The protection of individual economic freedom - as a value in itself - was regarded as the primary objective of competition policy." LOWE, Philip, Consumer Welfare and Efficiency - New Guiding Principles of Competition Policy? , discurso datado de 27 de março de 2007, apresentado em 13th International
} 
Conforme explica GORMSEN ${ }^{185}$, as ideias ordoliberais apareceram como resposta ao colapso sócio-econômico e político que resultou da queda da República de Weimar em 1933 e do nascimento da Alemanha nazista. De acordo com a autora, uma das consequências do regime totalitarista nazista foi transformar poder econômico privado em poder político. Assim, cartéis bem organizados e diversos monopólios teriam resultado de significativa concentração econômica, associada à acumulação de poder político, situação esta que teria levado ao abandono de princípios democráticos.

Ainda de acordo com GORMSEN, os ordoliberais acreditavam que o acúmulo do poder econômico teria sido resultado da incapacidade do sistema jurídico de prevenir a criação e o abuso do poder econômico privado. A falta de controles adequados contra o aumento do poder econômico e a fraqueza do Estado teriam resultado na substituição da liberdade econômica e política por uma "ditadura sem limites". Assim, para evitar a repetição da história e impedir que o poder econômico se tornasse poder político, seria necessário estabelecer uma ordem econômica apropriada, para proteger a liberdade econômica individual. Na visão ordoliberal, portanto, a liberdade econômica individual e a concorrência estariam na origem da prosperidade e da liberdade política. ${ }^{186}$

Conforme explica GERBER, os teóricos ligados à Escola Ordoliberal desenvolveram um grupo de ideias sobre a relação entre instituições políticas e econômicas que combinavam a economia clássica do laissez-faire e conceitos de intervenção estatal. De acordo com esta visão, a história teria demonstrado que, sem a intervenção governamental, os processos de concorrência tenderiam ao colapso, porque agentes econômicos que tinham domínio de mercado, com frequência abusariam desta situação, caso não sofressem pressões competitivas.

Conference on Competition e 14th European Competition Day, disponível em http://ec.europa.eu/competition/speeches/text/sp2007_02_en.pdf, acesso em novembro de 2011.

${ }_{185}$ GORMSEN, Linda L. The Conflict Between Economic Freedom and Consumer Welfare in the Modernization of Article 82 EC. In: European Competition Journal, v. 3, n. 2, December 2007, p. 332.

${ }^{186} \mathrm{Na}$ explicação de GERBER: "The Weimar experience led ordoliberals to demand the dispersion of not only political power, but economic power as well. For most, this meant the elimination of monopolies. For others, such as Wilhelm Ropke, the concentration of economic resources was an evil in itself; they sought an economy composed, to the extent possible of small and medium sized firms." GERBER, David. Constitutionalizing the Economy: German Neo-Liberalism, Competition Law and the "New" Europe. In: American Journal of Competition Law, v. 42, 1994, p. 36-37. 
Um dos principais componentes do programa ordoliberal, ainda de acordo com GERBER, era a ideia de que, em situações em que a concorrência era fraca ou inexistente, o Estado deveria impor aos agentes econômicos que eles conduzissem suas atividades "como se houvesse concorrência". O conceito de "como se houvesse concorrência" baseava-se na premissa de que a ciência econômica poderia determinar com razoável precisão se uma determinada conduta seria consistente com condições definidas como “competitivas". GERBER explica, ainda, que a noção de agir "como se houvesse concorrência" seria intimamente associada ao conceito de "concorrência de desempenho" (Leitungswettbewerb) ou concorrência no mérito. Os ordoliberais, portanto, assumiam que, ao implementar um padrão de que agentes econômicos se comportassem "como se houvesse concorrência", o Estado estaria assegurando melhor desempenho dos agentes econômicos no mercado, uma vez que o uso abusivo do poder econômico seria controlado. ${ }^{187}$ Quando, ao contrário, um agente econômico utilizasse o seu poder para prejudicar o desempenho de um rival (e.g. ao excluir um rival do mercado), este agente econômico estaria interferindo com o processo concorrencial, e o Estado deveria intervir e reprimir esta conduta. Neste sentido, o padrão de "como se houvesse concorrência" proibiria o que os ordoliberais chamavam de "concorrência por impedimento" (impediment competition ou Behinderungswettbewerb). ${ }^{188}$

Apesar da frequência com a qual se faz referência ao pensamento ordoliberal como influência principal da disciplina do abuso adotado na Europa, WHISH aponta que um recente estudo contesta este entendimento, ao investigar as discussões que precederam a edição da norma. ${ }^{189}$ De acordo com o referido estudo ${ }^{190}$, a intenção do legislador, ao redigir o referido artigo 102, não teria sido a proteção aos concorrentes (visão que estaria alinhada à abordagem ordoliberal, que buscava coibir a "concorrência por impedimento"), mas a proteção aos consumidores. Por este motivo, explica WHISH, a redação do artigo 102 foi

\footnotetext{
${ }^{187}$ GERBER, David J. Law and the Abuse of Economic Power in Europe. In: Tulane Law Review, v. 62, 1987-1988, p. 69-70.

${ }^{188}$ GERBER, David. Constitutionalizing the Economy: German Neo-Liberalism, Competition Law and the "New" Europe. In: American Journal of Competition Law, v. 42, 1994, p. 53.

${ }^{189}$ WHISH, Richard. Competition Law. 6th Edition, LexisNexis Buttersworths, 2008, p. 193.

${ }^{190}$ AKMAN, Pinar. Searching for the Long-Lost Soul of Article 82 EC. CCP Working Paper 07-5, dezembro de 2007, acessível em http://www.uea.ac.uk/polopoly fs/1.104585!ccp07-5.pdf, acesso em novembro de 2011.
} 
direcionada precipuamente aos chamados abusos de exploração, tais como a imposição de preços e condições injustas, e a limitação de mercados em prejuízo ao consumidor.

Quanto ao abuso de posição dominante, WHISH explica que não há uma definição que tenha sido adotada pelas autoridades europeias que possa englobar os vários tipos de abuso. O autor, no entanto, busca sumarizar alguns princípios norteadores que são úteis à sua compreensão, a saber: (i) um comportamento somente será abusivo se causar ou tiver a probabilidade de causar danos claros e demonstráveis aos consumidores (o que seria consistente com o propósito de proteger o bem estar do consumidor por meio da proteção ao processo competitivo); (ii) o artigo 102 não deve ser aplicado simplesmente para proteger concorrentes (seu propósito é promover o bem estar do consumidor e consumidores geralmente não se beneficiam da proteção de agentes econômicos ineficientes); e (iii) a aplicação da disciplina à repressão do abuso de posição dominante não deve se focar no curto prazo. ${ }^{191}$

No que diz respeito especificamente aos abusos de exclusão, LANG e O’DONOGHUE ${ }^{192}$ apontam que a prática decisória da Comissão Europeia e dos tribunais comunitários não oferece uma definição clara ou consistente do que estes seriam. De acordo com os autores, nenhuma definição teria um conteúdo normativo suficiente, para ser aplicado como uma regra a ser seguida por agentes econômicos que contemplem adotar uma determinada prática comercial com potencial de exclusão.

Ao longo dos anos, a Comissão Europeia e os tribunais europeus tiveram a oportunidade de examinar diversas práticas que tinham potencial de exclusão anticoncorrencial, quais sejam: acordos de exclusividade, vendas casadas, recusas de venda, descontos e práticas com efeitos similares, preços predatórios, recusa de licenciamento, entre outros.

A ênfase da atuação das autoridades comunitárias europeias com relação ao ilícito de abuso de posição dominante com efeitos de exclusão e a importância do bem estar do

\footnotetext{
${ }^{191}$ WHISH, Richard. Competition Law. 6th Edition, LexisNexis Buttersworths, 2008, p. 194-195.

192 TEMPLE LANG, John; O'DONOGHUE, Robert. The Concept of Exclusionary Abuse under Article 82. In: GCLC Research papers on Article 82 EC, July 2005, p. 39. Neste artigo, Os autores descrevem uma série de definições utilizadas pelos tribunais comunitários, concluindo que estas não seriam capazes de satisfazer requisitos básicos de segurança jurídica.
} 
consumidor neste contexto foi formalizada com a edição, em 2009, das já referidas orientações sobre prioridades na aplicação do artigo 102 a comportamentos de exclusão abusivos por parte de empresas em posição dominante (Documento Europeu sobre Abusos de Exclusão). ${ }^{193}$ No discurso de consulta pública que deu origem às mencionadas orientações, a então Comissária Europeia para Concorrência Neelie Kroes declarou que a política antitruste com relação a abuso de posição dominante deveria dar prioridade aos abusos de exclusão ${ }^{194} \mathrm{e}$, em outra ocasião, declarou expressamente que o propósito da discussão acerca dos abusos de exclusão era o de "proteger a concorrência no mercado como forma de melhorar o bem estar do consumidor e assegurar uma alocação eficiente de recursos". 195

O Documento Europeu sobre Abusos de Exclusão declara como um de seus objetivos "tornar mais claro e previsível o quadro geral utilizado pela Comissão na análise e decisão quanto à abertura de processos relativamente a diferentes formas de comportamentos de exclusão e ajudar as empresas a avaliarem melhor se um determinado comportamento pode dar azo a uma intervenção por parte da Comissão ao abrigo do artigo 82" (item 2). O documento, ainda, trata dos seguintes comportamentos como formas específicas de abuso: acordos exclusivos (incluindo descontos condicionais); vendas subordinadas e agrupadas (incluindo descontos multi-produtos); comportamento predatório , recusa de venda e compressão de margens.

\footnotetext{
${ }^{193}$ Comunicação da Comissão — Orientação sobre as prioridades da Comissão na aplicação do artigo 82.o do Tratado CE a comportamentos de exclusão abusivos por parte de empresas em posição dominante (2009/C 45/02) 24.2.2009. Jornal Oficial da União Europeia, disponível em http://eurlex.europa.eu/LexUriServ/LexUriServ.do?uri=OJ:C:2009:045:0007:0020:PT:PDF, acesso em novembro de 2010.

${ }^{194}$ KROES, Neelie. Preliminary Thoughts on Policy Review of Article 82, speech delivered at the Fordham $\begin{array}{llllll}\text { Corporate Law Institute } & \text { on }\end{array}$ (http://europa.eu/rapid/pressReleasesAction.do?reference=SPEECH/05/537\&format=HTML\&aged=0\&langu age $=$ EN\&guiLanguage $=$ en).

195 "Consumer welfare is now well established as the standard the Commission applies when assessing mergers and infringements of the Treaty rules on cartels and monopolies. Our aim is simple: to protect competition in the market as a means of enhancing consumer welfare and ensuring and efficient allocation of resources." KROES, Neelie, SPEECH/05/512, de 15 de setembro de 2005, acessível em www.ec/europa/eu.
} 


\subsection{Os dois modelos contrastados}

Diversos escritos buscam fazer uma comparação entre os modelos adotados nos Estados Unidos e aquele adotado pela Europa. ${ }^{196}$ Como já dito, os dois modelos costumam ser utilizados como referência para outros sistemas que pretendem adotar normas de repressão ao abuso de posição dominante.

As diversas tentativas de comparação observam que, não obstante alguma aproximação entre os dois modelos, a forma de tratamento do ilícito nos dois sistemas diverge de várias maneiras. A ausência de convergência quanto à disciplina de repressão ao ilícito de poder de mercado entre os dois modelos tem sido objeto de diversos escritos na última década, que a contrastam com uma tendência à convergência em outras áreas do direito concorrencial, tais como combate a cartéis, controle operações de concentração econômica e, em menor grau, o tratamento de acordos verticais. ${ }^{197}$

Em comum, os dois modelos estabelecem um elemento estrutural e um elemento de conduta. $\mathrm{O}$ elemento estrutural no direito comunitário europeu é a existência de posição dominante, enquanto que o elemento de estrutura nos Estados Unidos é a existência de poder de monopólio. A participação de mercado utilizada como referencial acerca do parâmetro acima do qual um determinado agente econômico deteria poder de monopólio ou posição dominante difere em cada sistema.

Conforme explicam GAVIL, KOVACIC e BAKER, nos Estados Unidos, um agente econômico geralmente não é considerado como detendo poder de monopólio com menos de $70 \%$ para os casos de monopolização. ${ }^{198} \mathrm{Na}$ Europa, o marco de participação de mercado

\footnotetext{
${ }^{196}$ Exemplificativamente, ver: FOX, Eleanor M. Abuse of dominance and monopolization: how to protect competition without protecting competitors. In: EUI-RSCA/EU Competition 2003.; FOX, Eleanor M. Monopolization, Abuse of Dominance, and the Indeterminacy of Economics: The U.S./E.U. Divide. In: Utah Law Review, 2006, p. 725-740. KOVACIC, William. Competition Policy in the European Union and the United States: Convergence or Divergence? Artigo apresentado na Bates White Fifth Annual Antitrust Conference, em 2 de junho de 2008, acessível em http://www.ftc.gov/speeches/kovacic/080602bateswhite.pdf. HAWK, Barry E. Article 82 and Section 2: Abuse and Monopolization Conduct. In: Issues in Competition Law and Policy, Volume II, 2008, ABA Section of Antitrust Law, p. 871-893.

197 "Unilateral abuse of market power is proscribed by most competition regimes. While there is growing convergence in competition law and policy across many areas, this subject is characterized by greater division than others."CALVANI, Terry and FINGLETON, John. Dominance: A Comparative Analysis. In: Issues in Competition Law and Policy, Volume II, 2008, ABA Section of Antitrust Law, p. 845.

${ }^{198}$ GAVIL, Andrew I; KOVACIC, William E.; BAKER, Jonathan B. Antitrust Law in Perspective: Cases, Concepts and Problems in Competition Policy. American Casebook Series, Thompson West, Second Edition, 2008, p. 719.
} 
utilizado para definir quando um determinado agente econômico detém posição dominante é geralmente mais baixo do que o utilizado no modelo dos Estados Unidos. Conforme o Documento Europeu sobre Abusos de Exclusão, agentes econômicos com menos de $40 \%$ de mercado teriam menor probabilidade de deter posição dominante, sendo que podem existir casos específicos em que agentes econômicos sejam considerados dominantes mesmo abaixo deste limiar, quando "concorrentes não tenham a capacidade de pressionar de forma eficaz a conduta da empresa dominante" (item 15).

Apesar de os dois modelos utilizarem testes conceitualmente similares para definir o elemento estrutural a doutrina costuma apontar para o fato de que o conceito de domínio de mercado adotado pelos europeus é mais inclusivo do que o teste de poder de monopólio dos norte-americanos. ${ }^{199}$ Conforme aponta HAWK, um exame da jurisprudência europeia demonstra que a Comissão Europeia tenderia a inferir a existência de posição dominante com base em fatores não relacionados exclusivamente à participação de mercado, tais como vantagens competitivas, vantagens tecnológicas em relação a concorrentes, marcas reconhecidas, uma rede de distribuição forte e consolidada, economias de escala, nível de integração vertical, entre outros. ${ }^{200}$

FOX explica que o sistema europeu tem um "centro de gravidade" diverso do sistema norte-americano. Enquanto o artigo 102 do Tratado CE condenaria todas as condutas cobertas pela Seção 2 do Sherman Act, ele tende a cobrir maior gama de comportamentos, incluindo usos de poder que não necessariamente aumentam poder de mercado. Um agente econômico em posição dominante teria, de acordo com FOX, o dever de não excluir concorrentes por atos que não envolvam "concorrência no mérito". ${ }^{201} \mathrm{Em}$ sentido semelhante, KOVACIC aponta que a interpretação do artigo 102 tende a criar maior margem de responsabilidade a agentes econômicos em posição dominante do que as

\footnotetext{
${ }^{199}$ GAVIL, Andrew I; KOVACIC, William E.; BAKER, Jonathan B. Antitrust Law in Perspective: Cases, Concepts and Problems in Competition Policy. American Casebook Series, Thompson West, Second Edition, 2008, p. 719.

${ }^{200}$ HAWK, Barry E. Article 82 and Section 2: Abuse and Monopolization Conduct. In: Issues in Competition Law and Policy, Volume II, 2008, ABA Section of Antitrust Law, p. 872.

${ }^{201}$ FOX, Eleanor M. Abuse of dominance and monopolization: how to protect competition without protecting competitors. In: EUI-RSCA/EU Competition 2003, p. 1
} 
decisões proferidas pelos tribunais dos Estados Unidos acerca da Seção 2 do Sherman Act. $^{202}$

A ausência de convergência entre os dois modelos pode ser explicada por uma série de fatores, tais como: origens histórico-legislativas, diferentes desenhos institucionais e legislativos, diferentes focos de políticas públicas, diferenças entre correntes teóricas econômicas aplicadas em cada sistema, diferenças entre os objetivos da disciplina da concorrência, entre outros.

GERBER critica as diversas tentativas de comparação entre os dois modelos e as discussões acerca de uma possível convergência, por entender que estas tentativas, em sua maioria, ignoram o papel que a análise econômica pode desempenhar em cada modelo. GERBER considera que a forma pela qual as instituições responsáveis pela aplicação da legislação antitruste utilizam a análise econômica é uma questão ainda pouco explorada nos escritos acerca de convergência de leis sobre abuso de posição dominante. Adita, ainda, que os contextos processuais têm influência no papel desempenhado pela análise econômica em cada modelo. Assim, instituições e processos estruturam o papel desempenhado pela análise econômica na disciplina do abuso de posição dominante e, portanto, estes fatores devem ser levados em consideração em análises comparativas e sobre convergência. ${ }^{203}$

Em sentido semelhante, FOX aponta que o próprio exercício de comparação entre os dois sistemas demonstra que a teoria econômica, por si só, não é definidora dos resultados de análises em cada sistema e que há uma gama importante de premissas, presunções e perspectivas que podem determinar resultados em cada sistema. ${ }^{204}$

\footnotetext{
202 "The interpretations of Article 82 by the Court of First Instance (CFI) and the Court of Justice have tended to create a wider zone of liability for dominant firms than the decisions of the US courts under Section 2 of the Sherman Act. At the margin, US courts have tended to say that courts and enforcement agencies commit greater errors by intervening too much rather than too little." KOVACIC, William. Competition Policy in the European Union and the United States: Convergence or Divergence? Artigo apresentado na Bates White Fifth Annual Antitrust Conference, em 2 de junho de 2008, acessível em http://www.ftc.gov/speeches/kovacic/080602bateswhite.pdf, p. 11.

${ }^{203}$ GERBER, David J. Convergence in the Treatment of Dominant Firm Conduct: The United States, The European Union, and the Institutional Embeddedness of Economics. Antitrust Law Journal, Vol. 76, p. 951952.

${ }^{204}$ No original: "This very exercise has demonstrated once again that economics is not hard science, and that, within an important range, assumptions, presumptions, and perspective determine the outcome." FOX, Eleanor M. Monopolization, Abuse of Dominance, and the Indeterminacy of Economics: The U.S./E.U. Divide. In: Utah Law Review, 2006, p. 725.
} 


\subsection{O modelo brasileiro}

Como já dito, entendemos que o modelo brasileiro de repressão ao abuso de posição dominante alinha-se ao modelo do direito comunitário concorrencial europeu. Esta constatação pode ser deduzida a partir de uma série de aspectos.

Inicialmente, observa-se que a disciplina de repressão ao abuso de posição dominante no Brasil insere-se no contexto da instrumentalidade da disciplina da concorrência de forma mais geral, já tratada no Capítulo I. De fato, como vimos, a própria previsão no artigo 173 da Constituição Federal já indica o seu caráter instrumental, e sua interpretação demonstra que são vários os valores perseguidos pela disciplina da concorrência no Brasil e, portanto, pela disciplina da repressão ao abuso de posição dominante. O caráter de instrumentalidade reforça, pois, o entendimento que a concorrência não é um fim em si mesmo - outros valores foram e devem ser levadas em consideração na interpretação das normas concorrenciais, inclusive, as relativas à repressão do abuso de posição dominante. Nesse ponto, parece-nos que o sistema brasileiro aproxima-se do sistema europeu, cujo caráter instrumental é mais acentuado do que o norte-americano.

Em segundo lugar, a estrutura dos dispositivos relativos ao abuso de posição dominante assemelha-se ao artigo 102 do Tratado CE, ao estabelecer um enunciado geral e, a seguir, uma lista exemplificativa (não exaustiva) de condutas que podem ser consideradas como infrações à ordem econômica. A estrutura dos artigos 20 e 21 da Lei 8.884/94 e do artigo 36 da Lei 12.529/2011 remete à estrutura do diploma europeu, ao propor um enunciado geral associado a um rol ilustrativo de condutas.

Quanto aos dispositivos da Lei 12.529/2011 acerca do ilícito de abuso de posição dominante, estes reproduziram, em linhas gerais, os dispositivos da Lei 8.884/94 relativo às infrações à ordem econômica, com algumas diferenças pontuais.

O artigo 36 da Lei 12.529/2011 e seus incisos praticamente reproduziram o artigo 20 da Lei 8.884/94 e incisos, ao estabelecer que: "constituem infração da ordem econômica, independentemente de culpa, os atos sob qualquer forma manifestados, que tenham por objeto ou possam produzir os seguintes efeitos, ainda que não sejam alcançados”: "limitar, falsear ou de qualquer forma prejudicar a livre concorrência ou a livre 
iniciativa"; "dominar mercado relevante de bens ou serviços"; e "aumentar arbitrariamente os lucros; e"exercer de forma abusiva posição dominante".

O parágrafo $1^{\circ}$ do artigo 36 também reproduz quase integralmente o parágrafo $1^{\circ}$ do artigo 20 da Lei 8.884/94 e esclarece que "a conquista de mercado resultante de processo natural fundado na maior eficiência de agente econômico em relação a seus competidores não caracteriza o ilícito previsto no inciso II do caput deste artigo”. O dispositivo, portanto, confirma o sistema da Lei 8.884/94, de acordo com o qual a posição dominante em si não é um ilícito.

Já quanto ao dispositivo que trata da presunção acerca da existência de posição dominante, a Lei 12.529/2011 traz algumas inovações, como já brevemente tratado no início deste capítulo. O parágrafo $2^{\circ}$ do artigo 36 estabelece que "presume-se posição dominante sempre que uma empresa ou grupo de empresas for capaz de alterar unilateral ou coordenadamente as condições de mercado ou quando controlar $20 \%$ (vinte por cento) ou mais do mercado relevante, podendo este percentual ser alterado pelo Cade para setores específicos da economia."

Quanto a este dispositivo, alguns aspectos são dignos de nota. De início, observa-se que a Lei 12.529/2011 manteve o percentual de 20\% ou mais de um mercado relevante, como sendo o patamar acima do qual se presume que um agente econômico detém posição dominante. Em segundo lugar, o dispositivo traz uma inovação combinando a presunção da participação de mercado com o fato de uma empresa (ou grupo de empresas) ser capaz de como dito, unilateral ou coordenadamente - alterar as condições de mercado. Finalmente, o dispositivo parece deixar mais explícita a possibilidade de que uma ou mais empresas possam abusar de posição dominante de forma conjunta, ao indicar que uma empresa ou grupo de empresas sejam capazes de unilateral ou coordenadamente alterar condições de mercado. A redação anterior era mais ambígua e não deixava, em nossa opinião, tão clara a possibilidade do abuso de posição dominante conjunta ou coletiva (joint or collective dominant position), figura existente no direito europeu, mas pouco explorada entre nós. Não trataremos deste ponto neste trabalho. ${ }^{205}$

\footnotetext{
${ }^{205}$ Para uma discussão sobre posição dominante coletiva, ver WHISH. WHISH, Richard. Competition Law. 6th Edition, LexisNexis Buttersworths, 2008, p. 558 e seguintes.
} 
Quanto ao rol de condutas que podem configurar infrações à ordem econômica, o parágrafo $3^{\circ}$ do artigo 36 traz alguns novos comportamentos e exclui outros, que constavam da Lei 8.884/94. Além da exclusão do inciso relativo aos preços excessivos (antigo item XXIV do artigo 21 da Lei 8.884/94), já tratado no Capítulo II, o rol exemplificativo também deixou de incluir inciso constante no projeto de lei referente à exclusividade. ${ }^{206}$

Em linha com o que já dissemos quanto aos preços excessivos, entendemos que a não inclusão da exclusividade entre os comportamentos listados no parágrafo $3^{\circ}$ do artigo 36 da Lei 12.529/2011 não significa que a exclusividade não poderia, de acordo com a nova lei, ser considerada como uma infração à ordem econômica. Isto porque, reiteramos, o rol do referido parágrafo é meramente exemplificativo e não exaure todas as situações que, caso venham a incidir em quaisquer dos incisos do caput artigo 36, podem configurar infração à ordem econômica. Em segundo lugar, outros incisos constantes do rol exemplificativo do parágrafo $3^{\circ}$ serviriam de fundamento para que a exclusividade viesse a ser considerada como um potencial ilícito. Entre estes, podemos citar o inciso III ("limitar ou impedir o acesso de novas empresas ao mercado"), inciso IV ("criar dificuldades à constituição, ao funcionamento ou ao desenvolvimento de empresa concorrente ou de fornecedor, adquirente ou financiador de bens ou serviços") e o inciso V ("impedir o acesso de concorrente às fontes de insumo, matérias-primas, equipamentos ou tecnologia, bem como aos canais de distribuição"). A não inclusão da exclusividade do rol de comportamentos listados nos incisos do parágrafo $3^{\circ}$, do artigo 36, da Lei 12.529/2011, portanto, não significa que a exclusividade não possa configurar infração à ordem econômica e, mais especificamente, um abuso de posição dominante tendente à exclusão.

\footnotetext{
${ }^{206}$ O referido inciso tinha a seguinte redação: "exigir ou conceder exclusividade, inclusive territorial, de distribuição de bens ou de prestação de serviços."
} 


\section{PANORAMA DAS DIFICULDADES NO TRATAMENTO DAS CONDUTAS DE EXCLUSÃO}

\subsection{Conceituação e definição de condutas de exclusão}

Conforme vimos nos itens anteriores, não há uma definição única sobre o que sejam condutas de exclusão. Possivelmente, a melhor forma de se pensar em condutas de exclusão é a partir dos efeitos que um determinado comportamento pode causar ou a partir da diferenciação feita no início do capítulo entre as ideias de colusão e exclusão e entre as ideias de exploração e de exclusão.

Vale lembrar que um comportamento pode ter um efeito de exclusão e não ser considerado um ilícito. Neste ponto, vale referir trecho do Documento Europeu sobre Abusos de Exclusão: "a Comissão reconhece que o mais importante é a protecção de um verdadeiro processo de concorrência e não a mera proteção de concorrentes". Sobre este ponto, ainda, conclui: "isto poderá significar que os concorrentes que tenham um desempenho inferior para os consumidores em termos de preço, gama de oferta, qualidade e inovação poderão desaparecer do mercado" (item 6). Conforme exemplifica HAWK, práticas bem sucedidas e pró-competitivas de um agente econômico podem excluir rivais, porém não ser consideradas ilícitas; o oferecimento de produtos de maior qualidade, por exemplo, pode excluir concorrentes e ser considerado um conduta concorrencial. ${ }^{207}$

Por outro lado, um comportamento tendente à exclusão pode configurar um ilícito, ainda que não leve à exclusão de rivais. Como veremos no próximo capítulo, este entendimento justifica-se com base na teoria do aumento dos custos dos rivais (raising rivals costs), desenvolvida por autores ligados à tradição pós-Chicago. De acordo com a teoria do aumento dos custos dos rivais, determinadas estratégias "de exclusão" são mais plausíveis, se consideradas como formas de aumentar os custos dos rivais e, não, como formas de excluí-los totalmente de um mercado.

Em síntese, conceituar um comportamento como tendente à exclusão não equivale dizer que ele será necessariamente ilícito. Esta constatação nos leva à indagação de como estabelecer a licitude ou ilicitude de comportamentos tendentes à exclusão.

\footnotetext{
${ }^{207}$ HAWK, Barry E. Article 82 and Section 2: Abuse and Monopolization Conduct. In: Issues in Competition Law and Policy, Volume II, 2008, ABA Section of Antitrust Law, p. 877.
} 


\subsection{A difícil distinção entre comportamento legítimo e conduta ilícita}

Como já dissemos, a principal dificuldade no tratamento dos ilícitos de abuso de poder posição dominante envolve a questão de definir quais comportamentos tendentes à exclusão de concorrentes de um agente econômico devem ser considerados legítimos e quais comportamentos devem ser considerados ilícitos. A dificuldade em responder a esta indagação é frequentemente referida nos escritos acerca dos ilícitos de abuso de posição dominante. $^{208}$

Nas palavras de GERBER, o problema central com esta categoria de casos é como distinguir uma conduta "abusiva" de uma conduta competitiva. A ideia de concorrência assume, por definição, que agentes econômicos buscarão ganhar a competição no mercado e isto pode significar, em muitos casos, causar prejuízos a competidores. De acordo com GERBER, o fato de uma determinada conduta ser direcionada a - ou ter o potencial de causar tais prejuízos, portanto, não pode servir de critério para definir uma conduta como abusiva. O critério deve ser encontrado nas características da conduta e em seus efeitos. ${ }^{209}$

LANG e O'DONOGHUE ${ }^{210}$ apontam que comportamentos legítimos e condutas de exclusão ilícitas podem ser muito semelhantes. Como exemplo, os autores referem-se a situações em que um agente econômico cobra preços baixos. Preços baixos, geralmente, traduzem um aspecto que sugere a existência de concorrência, mas podem, por vezes, ser muito baixos e ter o potencial de exclusão. Ainda, tanto a concorrência legítima quanto a conduta de exclusão ilícita podem prejudicar rivais, mas, no primeiro caso, o prejuízo é parte essencial de um processo competitivo adequado e desejável.

Ainda, voltando ao ponto referido no item anterior, deve ser observado que, por óbvio, nem toda conduta tendente à exclusão configurará um ilícito. Isto porque condutas tendentes à exclusão podem, além de não causar danos à concorrência, ter justificativas de

\footnotetext{
${ }^{208} \mathrm{O}$ seguinte trecho de uma das decisões proferidas pelos tribunais norte-amercianos bem resume o dilema: "Whether any particular act of a monopolist is exclusionary, rather than merely a form of vigorous competition, can be difficult to discern: the means of illicit exclusion, like the means of legitimate competition, are myriad. The challenge for an antitrust court lies in stating a general rule for distinguishing between exclusionary acts, which reduce social welfare, and competitive acts, which increase it." United States v. Microsoft, 253 F3d 34, 58 (D.C. Cir. 2001)

${ }^{209}$ GERBER, David J. Law and the Abuse of Economic Power in Europe. In: Tulane Law Review, v. 62, 1987-1988, p. 77-78.

${ }^{210}$ TEMPLE LANG, John; O’DONOGHUE, Robert. The Concept of Exclusionary Abuse under Article 82. In: GCLC Research papers on Article 82 EC, July 2005, p. 38.
} 
eficiência. Assim, a avaliação de uma conduta deve levar em consideração não somente os potenciais efeitos de exclusão da conduta, como também suas possíveis eficiências. ${ }^{211}$

\subsection{A teoria econômica}

O recurso à teoria econômica na análise de comportamentos tendentes à exclusão de agentes econômicos em posição dominante é parte relevante da análise antitruste. Ocorre que, como já dito, ao contrário do que ocorre em casos envolvendo cartéis, ainda há indefinição e controvérsia, na teoria econômica em geral, acerca de qual a melhor forma de avaliar os efeitos de tais comportamentos.

Além disto, como é sabido, não se pode fazer referência a uma "teoria econômica" de forma geral, sem contextualizar a que linha ou linhas teóricas estamos nos referindo. Por óbvio, existem várias linhas teóricas que já foram e que podem ser utilizadas como referencial na análise antitruste e, dentro de cada uma destas linhas, há padrões de análise sugeridos e aplicados por diferentes autoridades de defesa da concorrência a diferentes tipos de conduta. Estas linhas teóricas estão em constante evolução e, como veremos no próximo capítulo, há diversas proposições para a análise dos ilícitos de exclusão que vem "concorrendo entre si”, como sendo os adequados para a avaliação dos comportamentos.

Ainda, nos dizeres de GERBER, as teorias econômicas sofrem um processo de enraizamento institucional, o que significa que, ainda que determinadas linhas teóricas sejam aceitas como adequadas e funcionais em um determinado sistema, as mesmas linhas teóricas podem ser aplicadas de formas diferentes em outros sistemas, diante de peculiaridades das instituições que aplicam as normas concorrenciais e, até mesmo, aspectos procedimentais referentes a cada sistema jurídico. ${ }^{212}$

Em resumo, há indefinição e controvérsia, bastante atuais na literatura estrangeira (jurídica e econômica), acerca de quais linhas teóricas seriam mais apropriadas para a análise de condutas tendentes à exclusão. Uma discussão mais aprofundada sobre este aspecto será feita no próximo capítulo (Capítulo III).

\footnotetext{
${ }^{211}$ MELAMED, A. Douglas. Exclusive Dealing Agreements and Other Exclusionary Conduct - Are there Unifying Principles? In: Antitrust Law Journal, v. 73, 2005-2006, p. 375.

${ }^{212}$ GERBER, David J.. Competition Law and the Institutional embeddedness of economics. In: DREXL, Josef; IDOT, Lawrence; MONÉGER, Joel. Economic Theory and Competition Law, Chelteham: Elgar, 2009, p. 20-43.
} 


\subsection{O problema da prova do ilícito}

Uma dificuldade adicional na análise dos ilícitos de abuso de posição dominante refere-se à demonstração do ilícito. De início, deve ser definido o que deve ser demonstrado para que um determinado comportamento adotado por um agente em posição dominante seja considerado ilícito. Este aspecto, por si só, já oferece dificuldade. Assumindo, contudo, que um determinado sistema defina exatamente o que deve ser demonstrado para se demonstre o ilícito, a pergunta que segue é, por óbvio, como fazer a prova do ilícito.

Muitos autores questionam, ainda, a capacidade de as instituições responsáveis pela aplicação das normas em aplicar padrões de análise que sejam administráveis. Ainda que se chegue a um consenso sobre quais padrões jurídicos e econômicos devem ser aplicados na configuração do ilícito, resta saber se, na prática, as instituições serão capazes de aplicar tais padrões na prática.

\subsection{Mercados caracterizados por inovação}

HOVENKAMP ${ }^{213}$ aponta que muitos dos casos relacionados a ilícitos de monopolização nos Estados Unidos, ao longo de sua história, envolviam agentes econômicos que traziam inovações ou que atuavam em mercados caracterizados por inovação. HOVENKAMP aponta que, mesmo monopolistas que adquiriram sua posição dominante por força de legislação específica, como a AT\&T antes da famosa decisão que a separou em várias outras empresas em 1982, teriam sido responsáveis por importantes inovações.

A inovação abre novas possibilidades de práticas comerciais e cria oportunidades para práticas que dificilmente encontram analogias com casos anteriores. Este aspecto, segundo HOVENKAMP, faz que o ilícito de monopolização tenha uma qualidade "não repetitiva”, o que explica a dificuldade de definir a suposta ofensa, aumentando, assim, o perigo de que as normas de repressão ao abuso de posição dominante sejam aplicadas de forma mais ampla do que o desejável em mercados de inovação. ${ }^{214}$

\footnotetext{
${ }^{213}$ HOVENKAMP, Herbert. The Antitrust Enterprise. Principles and Execution. Harvard University Press. 2005 , p. 151.

${ }^{214}$ HOVENKAMP, Herbert. The Antitrust Enterprise. Principles and Execution. Harvard University Press. 2005, p. 151.
} 
MANNE e WRIGHT ${ }^{215}$ observam que, nos Estados Unidos, o governo tem focado seus esforços de combate ao ilícito de monopolização em empresas inovadoras atuantes em indústrias de alta tecnologia. De acordo com os autores, agentes econômicos bem sucedidos, concorrendo em mercados caracterizados por inovação e por frequentes mudanças tecnológicas são alvos prováveis - porém problemáticos - de questionamento pelas autoridades antitruste. Segundo os autores, ainda, a aplicação das leis antitruste a agentes econômicos inovadores em mercados dinâmicos teria sempre sido e continua a ser uma proposição perigosa, não obstante significativos avanços da teoria econômica e jurídica.

MANNE e WRIGHT anotam que isto se explica em razão não somente das dificuldades em se identificarem as consequências concorrenciais de práticas comerciais de forma geral, mas, também em particular, devido à dificuldade em se identificarem consequências concorrenciais de inovações nos mercados caracterizados por alta tecnologia.

MANNE e WRIGHT ${ }^{216}$ ilustram estas dificuldades, ao lembrar da investigação iniciada pelas autoridades de defesa da concorrência norte-americanas contra a Microsoft em 1998. Naquela época, apontam os autores, seria difícil prever alguns desafios que seriam enfrentados pela Microsoft, entre eles, o crescimento da Linux e do Google, o sucesso comercial do IPod, o papel transformador dos usos de aparelhos móveis em esferas relacionadas ao âmbito da computação tradicional, além de várias outras inovações que surgiram na década seguinte e que continuam a surgir a cada momento.

Estes aspectos colocam em questão o papel do antitruste e, em particular, a disciplina de repressão ao abuso de posição dominante, nos mercados de alta tecnologia.

\footnotetext{
${ }^{215}$ MANNE, Geoffrey A.; WRIGHT, Joshua D. Google and the Limits of Antitrust: The Case Against the Case Against Google. In: George Mason University Law and Economics. Research Paper SeriesPaper No. 2010-19, p. 2, disponível em http://papers.ssrn.com/sol3/papers.cfm?abstract_id=1577556, acesso em novembro de 2011.

${ }^{216}$ MANNE, Geoffrey A.; WRIGHT, Joshua D. Google and the Limits of Antitrust: The Case Against the Case Against Google. In: George Mason University Law and Economics. Research Paper SeriesPaper No. 2010-19, p. 2, disponível em http://papers.ssrn.com/sol3/papers.cfm?abstract_id=1577556, acesso em novembro de 2011.
} 


\section{CAPÍTULO III - EXCLUSÃO E TEORIA ECONÔMICA}

\section{INTRODUÇÃO}

Como vimos no Capítulo I, as normas que disciplinam a concorrência podem ser influenciadas por diversos fatores que não estão limitados ao desenho legislativo adotado por cada sistema jurídico. Assim, a estrutura das regras pode ser mais ou menos permeável a fatores "externos" ao desenho legislativo.

No Capítulo II, observamos também que as normas relativas à disciplina do abuso de posição dominante são especialmente permeáveis a fatores externos. Em particular, considerando a dificuldade em conceituar e definir do que tratam os ilícitos de exclusão dificuldade esta comum às normas dos Estados Unidos, do direito comunitário europeu e do direito brasileiro da concorrência -, o recurso à teoria econômica pode ter especial relevância na compreensão e caracterização como ilícitos de determinados comportamentos adotados por agentes econômicos em posição dominante tendentes à exclusão.

$\mathrm{O}$ direito da concorrência, principalmente o norte-americano, sempre foi profundamente influenciado pela teoria econômica dominante a cada época. ${ }^{217}$ Em especial, a evolução da política antitruste relativa aos chamados "ilícitos de monopolização" nos Estados Unidos é uma área em que a influência da teoria econômica é bastante marcada e usualmente comentada. ${ }^{218} \mathrm{Na}$ Europa, a relação entre a teoria econômica e o direito da concorrência nunca foi tão forte quanto nos Estados Unidos. ${ }^{219}$ Isto se explica, entre outros aspectos, devido ao importante papel que o direito da concorrência teve no processo de integração da Comunidade Europeia, principalmente nos primeiros anos de implementação do Tratado de Roma. ${ }^{220}$ Nos últimos anos, no entanto, algumas medidas demonstram que as

\footnotetext{
${ }^{217}$ Conforme HOVENKAMP: "Antitrust has always been closely tied to prevailing economic doctrine. To be sure, antitrust policy makers sometimes applied economics ineptly, sometimes gravitated toward the fringes of economic theory rather than the center, and sometime pushed good points too far." HOVENKAMP, Herbert, Federal Antitrust Policy - The Law of Competition and its Practice, St. Paul, Minn., Second Edition, West Publishing Co., 1999, p. 59; No mesmo sentido, GAVIL, Andrew; KOVACIC, William E.; BAKER, Jonathan B. Antitrust Law in Perspective: Cases, Concepts and Problems in Competition Policy. American Casebook Series, Thompson West, 2002, p. 61.

${ }^{218}$ GAL, Michael; TOR, Avishalom; WALLER, Spencer W. Expansion and Contraction in Monopolization Law. In: Antitrust Law Journal, v. 76, 2010, p. 653-661.

${ }^{219}$ MONTI, Giorgio. EC Competition Law. Cambridge University Press, 2007, p. 54.

${ }^{220}$ VAN DEN BERGH, Roger. The difficult reception of economic analysis in European Competition Law, In: CUCINOTTA, Antonio; PARDOLESI, Roberto; VAN DEN BERGH, Roger (eds.) Post-Chicago Developments in Antitrust Law. New Horizons in Law and Economics Series, Edward Elgar, 2002, p. 36.
} 
autoridades europeias têm buscado adotar uma abordagem em que a teoria econômica tenha um papel mais marcado ${ }^{221}$ como parte de transformações no direito europeu. ${ }^{222}$

No presente capítulo, pretende-se oferecer uma contextualização das correntes econômicas que buscam explicar os movimentos teóricos relativos à ideia de exclusão, com foco nos ilícitos de abuso de posição dominante. Consideramos que uma contextualização e tentativa de compreensão destas linhas teóricas é útil à formação da ideia de exclusão, sob o ponto de vista econômico, bem como de sua possível influência em decisões que venham a ser tomadas em casos envolvendo alegações de condutas de exclusão.

Os comentários feitos a seguir focam-se nas linhas teóricas desenvolvidas nos Estados Unidos desde a edição do Sherman Act até os dias de hoje. Esta abordagem se justifica devido à frequente referência feita a estas linhas teóricas não somente nos escritos da literatura antitruste norte-americana, mas também na literatura europeia e mesmo na doutrina e na jurisprudência brasileiras. Considerando que a experiência antitruste brasileira é ainda relativamente recente e, ainda, que o direito europeu somente nos últimos anos tem buscado adotar uma análise mais direcionada a determinados critérios econômicos ${ }^{223}$, colocando gradualmente os valores de integração de mercado e eficiência em plano secundário, parece-nos apropriado recorrer aos desenvolvimentos teóricos ocorridos nos Estados Unidos.

\footnotetext{
${ }^{221}$ Entre elas, a adoção de uma isenção em bloco (ou por categoria) para restrições verticais em 2000 (Regulamento (CE) no 2790/1999) e a Comunicação da Comissão - Orientação sobre as prioridades da Comissão na aplicação do artigo 82.o do Tratado CE a comportamentos de exclusão abusivos por parte de empresas em posição dominante (2009/C 45/02) 24.2.2009. Jornal Oficial da União Europeia, disponível em http://eur-lex.europa.eu/LexUriServ/LexUriServ.do?uri=OJ:C:2009:045:0007:0020:PT:PDF, acesso em novembro de 2011.

${ }^{222}$ MONTI, Giorgio. EC Competition Law. Cambridge University Press, 2007, p. 81. Conforme HAWK: "The Commission's public statements in the last several years emphasize consumer welfare at the expense of market integration and fairness. However, it is doubtful whether market integration and fairness can be eliminated entirely from Article 82 given that they are clearly expressed in the European Community Treaty (EC Treaty)". HAWK, Barry E. Article 82 and Section 2: Abuse and Monopolization Conduct. In: Issues in Competition Law and Policy, Volume II, 2008, ABA Section of Antitrust Law, p. 887.

${ }^{223}$ Conforme HAWK, ainda: "The Commission and the courts traditionally have interpreted "competition" more from the perspective of the Ordoliberal School (emphasis on economic freedom, business rivalry, market access, and rival opportunities) than from the perspective of welfare economics (emphasis on prices, output, and innovation), although the situation today is more nuanced with the increased influence of mainstrean welfare economics and the decline of Ordoliberal influence within the Commission." HAWK, Barry E. Article 82 and Section 2: Abuse and Monopolization Conduct. In: Issues in Competition Law and Policy, Volume II, 2008, ABA Section of Antitrust Law, p. 890.
} 
Não é nosso propósito trazer as discussões econômicas travadas em contextos outros para a realidade brasileira, não obstante o fato de que muitas vezes referências a estas teorias são feitas em nossa jurisprudência administrativa sem a necessária contextualização. ${ }^{224} \mathrm{O}$ desenho legislativo e o desenvolvimento da disciplina da repressão ao abuso de posição dominante no Brasil têm características próprias e não seria adequado, não obstante o suposto caráter de universalidade da teoria econômica, importar teorias alienígenas ao nosso sistema. ${ }^{225}$ A compreensão das linhas teóricas, no entanto, são úteis para a compreensão das discussões sobre exclusão de forma geral e, por este motivo, consideramos adequada a sua abordagem neste trabalho.

\footnotetext{
${ }^{224}$ A este respeito, ver SCHUARTZ. SCHUARTZ, Luis Fernando. A desconstitucionalização do direito de defesa da concorrência. In: Revista do IBRAC, São Paulo, v. 16, n.1, 2009, p. 325-351.

${ }^{225}$ Neste ponto, reiteramos as já mencionadas advertências de GERBER quanto ao suposto caráter de universalidade da ciência econômica: o desenho institucional de cada sistema jurídico condiciona o uso da análise econômica e suas práticas e processos influenciam não somente as regras que são aplicadas, mas também definem o papel que a análise econômica pode desempenhar em cada sistema e, portanto, influenciam as decisões que são tomadas na aplicação das normas. "Institutions condition the use of economics. Their practices and procedures influence not only the norms that are applied, including the appropriate role of economics, but also the factual material that is produced for use by economists and the myriad decisions that are made in reaching outcomes." GERBER, David J. Competition Law and the Institutional Embeddedness of Economics, November 24, 2008, In: Economic Theory and Competition Law, Josef Drexl, ed., disponível em http://ssrn.com/abstract=1306482, acesso em novembro de 2011, p. 21.
} 


\section{PANORAMA DAS PRINCIPAIS LINHAS TEÓRICAS}

\subsection{Introdução}

A literatura antitruste costuma classificar as diferentes linhas teóricas econômicas que influenciaram a aplicação de normas concorrenciais nos Estados Unidos com referência ao período identificado com a Escola de Chicago, que começou a ter repercussões doutrinárias na década de 1950 e que se desenvolveu de forma mais concreta a partir das décadas de 1960 e 1970. Conforme apontam EVANS e PADILLA, a referência à Escola de Chicago é geralmente utilizada para descrever uma linha divisória temporal e intelectual, que se refere tanto a uma forma de pensar sobre questões antitruste quanto a períodos durante os quais esta forma de pensar teria predominado. ${ }^{226}$ Nessa linha, é usual que se definam linhas intelectuais e temporais relacionadas a três períodos/linhas teóricas: o período pré-Chicago (ligado à Escola de Harvard), período da predominância da Escola de Chicago e o período em que se desenvolveram linhas teóricas denominadas como "pósChicago".

KOVACIC, no entanto, adverte que, apesar de grande parte da literatura estudar os desenvolvimentos teóricos que sucederam a Escola de Chicago como parte de um debate “Chicago vs. pós-Chicago", talvez esta descrição não seja a que reflita de forma mais precisa a moderna experiência antitruste norte-americana. ${ }^{227}$ De acordo com KOVACIC, o verdadeiro "DNA intelectual" do direito antitruste norte-americano deve ser visto como uma evolução e interação de ideias presentes na Escola de Chicago e na Escola de Harvard $^{228}$, interação esta que já incorporaria ideias associadas aos escritos pós-Chicago.

\footnotetext{
${ }^{226}$ EVANS, David; PADILLA, Jorge. Designing Antitrust Rules for Assessing Unilateral Practices: A NeoChicago Approach. In: University of Chicago Law Review, v. 72 (1), 2005, p. 76

227 "...the basis for my doubt is a growing sense that the habit of analyzing modern U.S. antitrust experience as a Chicago School/Post-Chicago School struggle obscures a critical intellectual foundation for the U.S. antitrust experience and, by diminishing our understanding of the sources of doctrine and enforcement policy, clouds our view of how the system might change in the future." KOVACIC, William E. The Intelectual DNA of Modern U.S. Competition Law for Dominant Firm Conduct: The Chicago/Harvard Double Helix. In: Columbia Business Law Review, v. 1, 2007, p. 6.

228 "The formative intellectual DNA of U.S. competition law and policy today towards dominant firms is a double helix that intertwines the contributions of scholars from the Chicago School and the Harvard School...The double helix imagery ... suggests... the interconnected and evolutionary nature of the modern body of dominant U.S. antitrust ideas." KOVACIC, William E. The Intelectual DNA of Modern U.S. Competition Law for Dominant Firm Conduct: The Chicago/Harvard Double Helix. In: Columbia Business Law Review, v. 1, 2007, p. 32.
} 
KOVACIC alerta, também, que grande parte dos autores que examinam o desenvolvimento das ideologias acerca do antitruste no decorrer do século XX refere-se à Escola de Harvard exclusivamente (ou principalmente) nos trabalhos mais antigos dos seus teóricos, identificados com BAIN, MASON e TURNER, nas décadas de 1940, 1950 e 1960. ${ }^{229}$ Neste contexto, explica KOVACIC, tais autores consideram a Escola de Harvard ultrapassada e, com exceção de referências pontuais acerca das contribuições de AREEDA e TURNER sobre preços predatórios, basicamente ignoram as contribuições mais recentes da Escola de Harvard à teoria e prática antitruste.

Em linha semelhante às advertências feitas por KOVACIC, HOVENKAMP explica que a Escola de Harvard passou por significativas transformações a partir da década de 1970 e não se identifica com a Escola de Harvard das décadas de 1930 a $1960 .{ }^{230}$ Os escritos mais recentes dos autores ligados à Escola de Harvard demonstrariam, entre outros aspectos, uma menor preocupação com barreiras à entrada e com operações de integração vertical e, ainda, não presumem que condutas anticompetitivas seriam uma consequência necessária da estrutura de determinada indústria. Nessa linha, HOVENKAMP sugere que, hoje, a "moderna" Escola de Harvard é apenas um pouco mais intervencionista do que a Escola de Chicago.

Feitas estas advertências, não obstante adotarmos a abordagem "tradicional" mencionada acima, ao longo a descrição que será feita adiante, faremos também referências às contribuições da "moderna" Escola de Harvard. Isto porque, além dos argumentos propostos por KOVACIC e HOVENKAMP, mencionados acima, parece-nos que alguns movimentos relacionados à ideia de exclusão somente podem ser corretamente compreendidos se consideradas as contribuições da "moderna" Escola da Harvard.

\footnotetext{
${ }^{229}$ KOVACIC, William E. The Intelectual DNA of Modern U.S. Competition Law for Dominant Firm Conduct: The Chicago/Harvard Double Helix. In: Columbia Business Law Review, vol. 1, 2007, p. 31.

${ }^{230}$ HOVENKAMP, Herbert. The Antitrust Enterprise. Principles and Execution. Harvard University Press. 2005, p. 37.
} 


\subsection{Escola de Harvard: os estruturalistas}

Conforme anotam GAVIL, KOVACIC e BAKER ${ }^{231}$, os ensinamentos da organização industrial das décadas de 1950 e 1960 tiveram grande influência sobre as ideologias que permearam a aplicação do antitruste nos Estados Unidos naquela época. A organização industrial focava-se em três características dos mercados, que eram consideradas relacionadas: estrutura, conduta e desempenho. Os teóricos ligados à organização industrial daquela época consideravam que as estruturas de mercado teriam grande influência na previsão de probabilidade de problemas concorrenciais e eram céticos acerca da capacidade de mercados concentrados resultarem em resultados concorrenciais. $\mathrm{O}$ ceticismo também se verificava com relação a alegações de eficiência, que eles consideravam de difícil mensuração, preferindo, portanto, a previsibilidade das premissas estruturais.

Até a década de 1960, portanto, a linha teórica que prevalecia na aplicação das leis antitruste nos Estados Unidos era a ligada à Escola de Harvard de organização industrial das décadas de 1930 a 1960. Também chamados de estruturalistas, os teóricos de Harvard pressupunham que a estrutura de uma determinada indústria poderia influenciar a conduta dos agentes econômicos nesta indústria. ${ }^{232}$ A estrutura de uma determinada indústria (i.e. número de vendedores e compradores e condições de entrada) influenciaria as condutas dos agentes econômicos; as condutas, por sua vez, influenciariam o desempenho econômico da indústria. Em linhas gerais, os estruturalistas previam que quanto maior o nível de concentração em determinada indústria, mais facilmente se verificariam condutas anticompetitivas. De acordo com esta perspectiva, o direito da concorrência deveria se preocupar com estruturas de mercado concentradas e, portanto, buscar prevenir ou modificar estas estruturas.

Os estruturalistas estudavam as características de determinadas indústrias em detalhes e, com base nos resultados, argumentavam que economias de escala raramente

\footnotetext{
${ }^{231}$ GAVIL, Andrew I; KOVACIC, William E.; BAKER, Jonathan B. Antitrust Law in Perspective: Cases, Concepts and Problems in Competition Policy. American Casebook Series, Thompson West, Second Edition, 2008, p. 65.

${ }^{232}$ FOX, Eleanor M.; SULlIVAN, Lawrence A. Cases and Materials on Antitrust. American Casebook Series, West Publishing Co., st. Paul, Minn., 1989, p. 112.
} 
tornariam necessário que as empresas se tornassem grandes, que agentes econômicos dominantes facilmente poderiam criar significativas barreiras à entrada de novos entrantes e que mercados funcionariam de forma anticoncorrencial mesmo em níveis baixos de concentração. ${ }^{233}$ Como resultado, a abordagem estruturalista conduzia a uma política antitruste intervencionista, que condenava operações que resultavam em baixos níveis de concentração e demonstrava preocupação com várias formas de integração vertical e restrições verticais, tais como acordos de exclusividade, vendas casadas, preços predatórios e outras práticas, vistas como formas de aumentar barreiras à entrada. ${ }^{234}$

MOTTA descreve o período pré-Chicago como um período de intensa atividade antitruste nos Estados Unidos, caracterizada mais pelo desejo de restringir o comportamento de grandes empresas do que pelo objetivo de aumentar a eficiência econômica. $^{235}$ O’DONOGHUE e PADILLA consideram que a abordagem "pré-Chicago" poderia ser descrita como baseada em "intuições" acerca de quais práticas deveriam ser coibidas. Nessa linha, a Suprema Corte dos Estados Unidos teria utilizado uma abordagem intuitiva em muitos casos que examinaram condutas de exclusão nas primeiras décadas do século XX. ${ }^{236}$

\subsection{Escola de Chicago}

O movimento teórico conhecido como Escola de Chicago teve origem nos estudos de AARON DIRECTOR da década de $1950^{237}$, e foi popularizado nas décadas de 1960 e 1970, principalmente nos escritos de BORK e POSNER. ${ }^{238}$ Os autores ligados à Escola de Chicago questionaram diversos aspectos da política antitruste que vinha sendo aplicada nos

\footnotetext{
${ }^{233}$ Conforme síntese de JACOBS, Michael. An Essay on the Normative Foundations of Antitrust Economics. In: North Carolina Law Review, v. 74, 1995-1996, p. 227.

${ }^{234}$ HOVENKAMP, Herbert. The Antitrust Enterprise. Principles and Execution. Harvard University Press. 2005, p. 36.

${ }^{235}$ MOTTA, Massimo. Competition Policy: Theory and Practice. Cambridge University Press, 2004, p. 7.

${ }^{236}$ O'DONOGHUE, Robert; PADILLA, A Jorge. Law and Economics of Article 82 EC. Hart Publishing, 2006, p. 179.

${ }^{237}$ POSNER explica que DIRECTOR formulou grande parte de suas ideias oralmente. POSNER, Richard. The Chicago School of Antitrust Analysis. In: University of Pennsylvannia Law Review, v. 127, 1978-1979, p. 925-926.

${ }^{238}$ Outros nomes frequentemente citados como alinhados à Escola de Chicago são George Stigler, Edward Levi, Lester Telser, William Baxter e Frank Easterbrook. Os trabalhos mais conhecidos, no entanto, são os de BORK (BORK, Robert H. The Antitrust Paradox. A Policy at War with Itself, publicado originalmente em 1978) e POSNER (POSNER, Richard E. Antitrust Law: An Economic Perspective, publicado originalmente em 1977).
} 
Estados Unidos até a década de $1960 .{ }^{239}$ A Escola de Chicago enfatizava explicações de eficiência para fenômenos que eram geralmente vistos de forma suspeita pelas autoridades antitruste norte-americanas. $^{240}$

HOVENKAMP escreveu recentemente que a linha teórica identificada como a Escola de Chicago foi provavelmente a crítica mais coesa e sustentável já desenvolvida com relação à política antitruste até hoje. A Escola de Chicago oferecia uma visão elegante, pró mercado e largamente anti-intervencionista. ${ }^{241}$ Os teóricos de Chicago argumentavam que os mercados tenderiam a corrigir suas próprias imperfeições, que a história intervencionista nos Estados Unidos teria produzido resultados desastrosos e que os tribunais teriam condenado com frequência determinadas práticas sem ao menos compreendê-las adequadamente; assim, se estas práticas fossem melhor compreendidas, seria possível demonstrar que elas poderiam produzir resultados benéficos à concorrência ou ter explicações pró-competitivas. Os teóricos ligados à linha de Chicago, portanto, argumentavam que os tribunais deveriam estudar a fundo determinadas práticas comerciais antes de decidir se alguma intervenção seria necessária. ${ }^{242}$

A Escola de Chicago contestou a abordagem dos estruturalistas de diversas formas. Os teóricos questionavam a relação entre concentração da indústria e efeitos anticompetitivos e argumentavam que não se poderia presumir que a coordenação seria inevitável em mercados oligopolizados. ${ }^{243}$ A correlação estatística entre alta concentração e altas taxas de lucro não seria necessariamente causada por comportamentos anticompetitivos, mas seria o resultado de maior eficiência. Ainda, os teóricos de Chicago questionavam a definição de barreiras à entrada proposta pelos estruturalistas; a Escola de Chicago considerava que, em diversos mercados, a entrada era geralmente fácil e que as

\footnotetext{
${ }^{239}$ Para uma descrição das principais proposições de Chicago, ver POSNER (POSNER Richard. The Chicago School of Antitrust Analysis. In: University of Pennsylvannia Law Review, v. 127, 1978-1979) e HOVENKAMP (HOVENKAMP, Herbert. Antitrust Policy After Chicago. In: Michigan Law Review, v. 84, p. 212-284).

${ }^{240}$ KOVACIC, William E.; SHAPIRO, Carl. Antitrust Policy; A Century of Economic and Legal Thinking. In: Journal of Economic Perspectives, v. 14, n. 1, Winter 2000, p. 53.

${ }^{241}$ HOVENKAMP, Herbert. The Antitrust Enterprise: principle and execution. Harvard University Press, Cambridge, Massachusetts; London, England, 2005, p. 32.

${ }^{242}$ HOVENKAMP, Herbert. The Antitrust Enterprise: principle and execution. Harvard University Press, Cambridge, Massachusetts; London, England, 2005, p. 32.

${ }^{243}$ Conforme explicação de BAKER. BAKER, Jonathan B. A Preface to Post-Chicago Antitrust. In: VAN DEN BERGH, Roger et al. (eds.). Post-Chicago Developments in Antitrust Analysis, Edward Elgar, 2002.
} 
fontes mais prováveis de barreiras seriam justamente resultado de intervenções governamentais. $^{244}$

A Escola de Chicago considerava que os mercados normalmente tenderiam a se "auto-corrigir", que as falhas de mercado seriam transitórias e que a concorrência poderia ser mantida ou reestabelecida sem que fosse necessária a intervenção estatal. Os teóricos de Chicago, portanto, tinham uma visão otimista dos mercados e eram críticos e céticos com relação à intervenção de autoridades governamentais na forma de seu funcionamento. ${ }^{245}$

Nessa linha de confiança na capacidade de "auto-correção" dos mercados, a Escola de Chicago passou a argumentar que poucas situações ofereciam reais riscos à concorrência, quais sejam, os cartéis e as operações de concentração horizontal que reduzissem significativamente o número de agentes em determinado mercado, tendendo à facilitação de condutas coordenadas ou ao monopólio. ${ }^{246}$

No que diz respeito às condutas unilaterais de exclusão, a Escola de Chicago considerava que muitas das práticas identificadas como ilícitas pela jurisprudência e pela literatura então predominantes refletiriam formas de concorrência agressivas ou inovadoras. De acordo com os teóricos de Chicago, estas práticas não teriam qualquer efeito de exclusão ou excluiriam rivais simplesmente porque estes seriam menos eficientes. ${ }^{247}$

\footnotetext{
${ }^{244}$ Na explicação de HOVENKAMP: “"Natural” barriers to entry are more imagined than real. As a general rule investment will flow into any market where the rate of return is high. The one significant exception consists of barriers to entry that are not natural - that is, barriers that are created by government itself. In most markets would be best off if left entry and exit unregulated." HOVENKAMP, Herbert. Antitrust Policy After Chicago. In: Michigan Law Review, v. 84, p. 227.

${ }^{245}$ Sobre o "ceticismo" da Escola de Chicago, ver EASTERBROOK: "This is a profoundly skeptical program - skeptical of simple models, skeptical of simple analysis, skeptical of the ability of courts to make things better even with the best data." EASTERBROOK, Frank H. Workable Antitrust Policy. In: Michigan Law Review, v. 84, 1985-1986, p. 1701. Uma crítica ao ceticismo da Escola de Chicago é oferecida por HOVENKAMP, Herbert. Rhetoric and Skepticism in Antitrust Argument. In: Michigan Law Review, v. 84, n. 8, Aug., 1986, p. 1721.

${ }^{246}$ Conforme POSNER: “...the focus of the antitrust laws should not be on unilateral action; it should instead be on: (1) cartels and (2) horizontal mergers large enough to create a monopoly directly, as in the classic trust cases, or to facilitate cartelization by drastically reducing the number of significant sellers in the market." POSNER, Richard. The Chicago School of Antitrust Analysis. In: University of Pennsylvannia Law Review, v. 127, 1978-1979, p. 928. Na mesma linha, EASTERBROOK: “...Skepticism is why the Workable Antitrust Policy School seems to favor little other than prosecuting plain vanilla cartels and mergers to monopoly." EASTERBROOK, Frank H. Workable Antitrust Policy. In: Michigan Law Review, v. 84, 19851986, p. 1701.

${ }^{247}$ HOVENKAMP, Herbert. The Antitrust Enterprise: principle and execution. Harvard University Press, Cambridge, Massachusetts; London, England, 2005, p. 32.
} 
A Escola de Chicago desenvolveu modelos e raciocínios que buscavam demonstrar que determinadas condutas e arranjos, geralmente considerados ilícitos, tais como preços predatórios, vendas casadas e acordos de exclusividade, não seriam métodos racionais para adquirir ou preservar poder de mercado; pelo contrário, os modelos desenvolvidos pela Escola de Chicago procuravam explicar que estas práticas poderiam ser mecanismos para aumentar a eficiência. ${ }^{248}$

Nessa linha, práticas agressivas, tais como as ligadas à redução de preços, poderiam até prejudicar rivais, mas geralmente beneficiariam os consumidores. Condutas de agentes dominantes direcionadas contra seus rivais, contudo, somente deveriam ser consideradas ilícitas se também fosse demonstrado prejuízo aos consumidores. ${ }^{249}$

As proposições da Escola de Chicago tiveram influência significativa na aplicação das normas antitruste dos Estados Unidos, em particular, com relação à aplicação das normas relativas ao ilícito de monopolização. Os teóricos ligados à Escola de Chicago eram céticos com relação à possibilidade de agentes econômicos aumentarem seu poder de mercado de forma unilateral e, portanto, consideravam que diversos casos iniciados pelo governo norte-americano na aplicação da Seção 2 do Sherman Act não teriam qualquer mérito.

\subsection{Desenvolvimentos "pós-Chicago"}

A partir da década de 1980 novas contribuições teóricas - referidas de forma conjunta como "pós-Chicago" - passaram a questionar ou desenvolver alguns dos pressupostos da Escola de Chicago. Como já mencionado, a linha teórica identificada como "pós-Chicago" é considerada por grande parte da literatura antitruste atual como a "principal alternativa" intelectual à Escola de Chicago. ${ }^{250} \mathrm{~A}$ análise pós-Chicago passou a utilizar modelos mais sofisticados para demonstrar que, em determinadas circunstâncias,

\footnotetext{
${ }^{248}$ PAGE, William H.; LOPATKA, John E. The Microsoft Case: Antitrust, High Technology, and Consumer Welfare. The University of Chicago Press, 2007, p. 15.

249 BORK, um dos principais teóricos identificados com a linha de Chicago, argumentou, em seu Antitrust Paradox: "The law must become more sophisticated about techniques of predation. Presently, it fears exclusion from such things as price cutting and exclusive dealing, which are very rarely if ever predatory, and tends to pay too little attention to misuse of governmental processes and organized exchanges, where opportunities for predation are plentiful." BORK, Robert H. The Antitrust Paradox. A Policy at War with Itself. The Free Press, 1993, p. 160.

${ }^{250}$ KOVACIC, William E. The Intelectual DNA of Modern U.S. Competition Law for Dominant Firm Conduct: The Chicago/Harvard Double Helix. In: Columbia Business Law Review, v. 1, 2007, p. 22.
} 
muitas das práticas que os teóricos de Chicago consideravam benéficas à concorrência poderiam ser anticompetitivas. Os modelos pós-Chicago, portanto, formalizam e justificam algumas das proposições pré-Chicago, porém de uma forma mais qualificada. ${ }^{251}$

É necessário esclarecer, neste ponto, que os desenvolvimentos teóricos identificados como "pós-Chicago" não envolvem um corpo uniforme de proposições. ${ }^{252}$ Além disto, apesar de algumas linhas teóricas englobadas sob a denominação de "pós-Chicago" contestarem as proposições de Chicago, muitas delas apenas qualificam e complementam algumas destas proposições. ${ }^{253}$

As contribuições econômicas pós-Chicago consideram que os mercados são mais complexos e diversificados do que a Escola de Chicago pressupunha. Como consequência, a quantidade e variedade de práticas anticompetitivas não seriam conhecidas e estariam "em aberto", especialmente em mercados relativamente novos, nos quais as oportunidades para colusão e comportamentos estratégicos por agentes dominantes podem ser muitas. ${ }^{254}$ Dessa forma, as metodologias propostas pelos teóricos pós-Chicago são necessariamente mais complexas, refletindo a maior complexidade observada nos mercados. Em linhas gerais, as teorias pós-Chicago consideram que a intervenção governamental poderia ocorrer de forma mais presente do que a linha de Chicago pressupunha. ${ }^{255}$

\footnotetext{
${ }^{251}$ PAGE, William H.; LOPATKA, John E. The Microsoft Case: Antitrust, High Technology, and Consumer Welfare. The University of Chicago Press, 2007, p. 21.

${ }^{252}$ Conforme explica KOVACIC: "A second problem with explaining modern U.S. antitrust experience chiefly as a Chicago School/Post-Chicago School contest is the suggestion that each school is monolithic and single-minded. Neither body of literature features such a uniformity of preferences." KOVACIC, William E. The Intelectual DNA of Modern U.S. Competition Law for Dominant Firm Conduct: The Chicago/Harvard Double Helix. In: Columbia Business Law Review, v. 1, 2007, p.10.

253 "Post-Chicago commentators generally propose qualifying rather than supplanting Chicago views." GAVIL, Andrew; KOVACIC, William E.; BAKER, Jonathan B. Antitrust Law in Perspective: Cases, Concepts and Problems in Competition Policy. American Casebook Series, Thompson West, 2002, p. 68. Na explicação de KOVACIC: "The frequently-voiced suggestion that the Chicago School and the Post-Chicago School are antonyms overlooks important connections between the two bodies of thought. Many Post-Chicago School scholars build upon theoretical or empirical propositions advanced by Chicago School exponents." KOVACIC, William E. The Intelectual DNA of Modern U.S. Competition Law for Dominant Firm Conduct: The Chicago/Harvard Double Helix. In: Columbia Business Law Review, v. 1, 2007, p. 9.

${ }^{254}$ HOVENKAMP, Herbert. Post-Chicago Antitrust: A Review and Critique. In: Columbia Business Law Review, v. 2001, p. 268. "The real value of post-Chicago economics is its renewed recognition of the fact that markets are much more varied and complex than Chicago theorists were willing to admit. As a result the number and variety of anticompetitive practices is unknown and open ended, particularly in relatively new markets, such as the Internet and software licensing, where the opportunities for collusion and strategic behavior by dominant firms may prove to be quite manifold."

${ }^{255}$ HOVENKAMP, Herbert. Post-Chicago Antitrust: A Review and Critique. In: Columbia Business Law Review, v. 2001, p. 267. Na síntese de GELLHORN, KOVACIC e CALKINS: "Although couched in terms of
} 


\section{CONTRIBUIÇÕES ESPECÍFICAS RELACIONADAS À IDEIA DE EXCLUSÃO}

\subsection{Introdução}

As linhas teóricas brevemente sumarizadas acima trouxeram contribuições para o entendimento dos potenciais efeitos de exclusão dos comportamentos adotados por agentes econômicos em posição dominante. Nos próximos tópicos, trataremos brevemente das principais contribuições e transformações do pensamento econômico relacionados à ideia de exclusão, com foco nas contribuições às estratégias de distribuição que serão desenvolvidas no Capítulo IV, em particular, acordos de vinculação ou práticas de venda casada, acordos de exclusividade, recusas unilaterais de contratar e estratégias de distribuição menos convencionais (em particular, regimes de descontos e incentivos). As contribuições descritas a seguir, portanto, não têm o propósito de exaurir as discussões sobre exclusão trazidas por cada linha teórica, mas buscam identificar as contribuições que podem ter relevância aos comportamentos relacionados à distribuição mencionados acima.

\subsection{A exclusão e a teoria da alavancagem (leverage doctrine): impactos para os acordos de vinculação (tying)}

Uma das principais premissas da era pré-Chicago com relação à ideia de exclusão pode ser identificada na chamada teoria do alavancagem (leverage doctrine), de acordo com a qual um agente econômico dominante buscaria estender seu poder de mercado a mercados relacionados ou adjacentes. De acordo com esta teoria, um agente econômico dominante teria um incentivo a estender seu poder a mercados de produtos complementares e, desta forma, obter "lucros de monopólio" em dois mercados. Esta teoria tinha aplicação em situações que envolvessem situações de venda casada (tying).

A preocupação relacionada às práticas de venda casada (tying) seria a de que um agente em posição dominante em um determinado mercado vinculasse a compra do produto do mercado dominado a produtos complementares, que fizessem parte de mercados mais competitivos. Esta abordagem explica, em parte, o motivo de as praticas de venda casada terem sido tratadas, nos Estados Unidos como um ilícito per se. Vale notar que, atualmente,

economics, much of the debate between 'Chicago' and 'post-Chicago' reflects differing levels of faith in the self-correcting ability of markets, on the one hand, and in the ability of government intervention to improve matters, on the other." GELLHORN, E.; KOVACIC, W. E.; CALKINS, S. Antitrust Law and Economics in a Nutshell. 5th Edition. Thomson West, 2004, p. 106. 
nos Estados Unidos, entre as restrições verticais, somente aquelas envolvendo venda casada são tratadas de acordo com a regra per se; ainda assim, a regra per se adotada para casos de venda casada é bastante específica e alguns autores sugerem que, ao invés do rótulo de per $s e$, seria mais apropriado chamar de abordagem de "regra da razão estruturada". ${ }^{256}$ SALOP considera que, apesar de a regra per se contra vendas casadas não ter sido explicitamente eliminada, ela estaria com os dias contados. ${ }^{257}$

A Escola de Chicago trouxe uma contribuição teórica que se contrapunha à chamada leverage doctrine. Como já indicado, a chamada leverage doctrine condenava determinadas práticas verticais, em particular as práticas de venda casada, sob a premissa de que um agente econômico dominante em um mercado poderia se utilizar de instrumentos de vinculação para criar um segundo monopólio, no mercado do produto vinculado. Desta forma, o agente monopolista obteria dois "lucros de monopólio" ao destruir a concorrência também no mercado vinculado, ${ }^{258}$ prejudicando os compradores do produto vinculado e excluindo rivais neste mercado. ${ }^{259}$

Em artigo publicado em 1957, BOWMAN ${ }^{260}$ contestou a ideia então predominante de que a venda casada seria quase sempre anticompetitiva. BOWMAN argumentou que acordos de vinculação (ou de venda casada) poderiam ter usos pró-concorrenciais e que a ideia da alavancagem não seria viável na ausência de um motivo plausível para que um agente econômico dominante pudesse monopolizar o mercado do produto vinculado. Em linhas gerais, BOWMAN argumentava que um agente em posição dominante em um

${ }^{256}$ GELLHORN, E.; KOVACIC, W. E.; CALKINS, S. Antitrust Law and Economics in a Nutshell. 5th Edition, Thompson West, 2004, p. 379. Os autores consideram, ainda, que o rótulo per se aplicado às vendas casadas continua a ser adotado, não obstante o fato de que há amplo reconhecimento de que o teste per se para as vendas casadas é significativamente distinto do teste per se para cartéis de fixação de preço horizontais.

${ }^{257}$ No original: "The per se rule against tie-in sales has never been explicitly eliminated but it is certainly on its last legs". SALOP, Steven C. Economic Analysis of Exclusionary Vertical Conduct: Where Chicago has Overshot the Mark. In: PITOFSKY, Robert (Ed.). How the Chicago School Overshot the Mark. The Effect of Conservative Economic Analysis of U.S. Antitrust, Oxford University Press, 2008, p. 141.

${ }^{258} \mathrm{Na}$ síntese de HOVENKAMP: "the leverage theory condemned vertical practices such as tying arrangements by assuming that a monopolist in one product could use tying to create a second monopoly in a tied product, thus earning two monopoly profits while destroying competition in the tied product.".HOVENKAMP, Herbert. The Antitrust Enterprise: principle and execution. Harvard University Press, Cambridge, Massachusetts; London, England, 2005, p. 32-33.

${ }^{259}$ GAVIL, Andrew I; KOVACIC, William E.; BAKER, Jonathan B. Antitrust Law in Perspective: Cases, Concepts and Problems in Competition Policy. American Casebook Series, Thompson West, Second Edition, 2008, p. 810.

${ }^{260}$ BOWMAN, Ward S.. Tying Arrangements and the Leverage Problem. In: The Yale Law Journal, v. 67, n. 1, November 1957, p. 19-36. 
determinado mercado poderia maximizar o seu lucro ao cobrar preços de monopólio neste mercado, sendo que a vinculação a um outro produto/mercado não teria nada a acrescentar a este lucro. Desta forma, outra explicação deveria ser encontrada para justificar o entendimento de que esta conduta seria anticompetitiva.

Em outras palavras, de acordo com a proposição de BOWMAN, em determinadas circunstâncias, em uma cadeia vertical de produção, haveria um potencial fixo para lucro de monopólio. Um agente econômico com poder de monopólio em um determinado nível da cadeia aproveitaria todo o seu lucro de monopólio se ele cobrasse um preço de monopólio e os demais membros na cadeia cobrassem preços competitivos. Seria, portanto, do interesse do agente econômico dominante estimular a concorrência nos demais níveis da cadeia, porque o lucro de monopólio auferido pelos outros membros da cadeia reduziria o seu próprio lucro de monopólio. Variações desta proposição foram aplicadas às condutas de vendas casadas, instalações essenciais e, de forma mais geral, a análise de integrações verticais. ${ }^{261}$ Este argumento também é também usualmente referido como single monopoly profit theory. ${ }^{262}$

Conforme explicação de SALOP, o argumento da Escola de Chicago, portanto, era de que haveria apenas um "lucro de monopólio" a ser extraído pelo agente econômico dominante. Não seria possível estender este lucro por meio de acordos de vinculação para um "segundo monopólio", em um segundo mercado. Nesta linha de argumentação, como não haveria um motivo anticoncorrencial por trás destes arranjos, de acordo com os teóricos de Chicago, estes só poderiam ser motivados por questões relacionadas à eficiência. ${ }^{263}$

Apesar do impacto que as proposições de BOWMAN e outras contribuições ligadas à Escola de Chicago tiveram com relação à leverage doctrine, estas não eliminaram por completo as preocupações concorrenciais relacionadas aos comportamentos de venda casada. Conforme explicam GAVIL, KOVACIC e BAKER, as proposições de BOWMAN

\footnotetext{
${ }^{261}$ EVANS, David; PADILLA, Jorge. Designing Antitrust Rules for Assessing Unilateral Practices: A NeoChicago Approach. In: University of Chicago Law Review, v. 72 (1), 2005, p. 77.

${ }^{262}$ SALOP, Steven C. Economic Analysis of Exclusionary Vertical Conduct: Where Chicago has Overshot the Mark. In: PITOFSKY, Robert (Ed.). How the Chicago School Overshot the Mark. The Effect of Conservative Economic Analysis of U.S. Antitrust, Oxford University Press, 2008, p. 144 e seguintes.

${ }^{263}$ SALOP, Steven C. Economic Analysis of Exclusionary Vertical Conduct: Where Chicago has Overshot the Mark. In: PITOFSKY, Robert (Ed.). How the Chicago School Overshot the Mark. The Effect of Conservative Economic Analysis of U.S. Antitrust, Oxford University Press, 2008, p. 145.
} 
não neutralizaram as preocupações relacionadas aos efeitos de exclusão possivelmente resultantes das vendas casadas e práticas assemelhadas. De acordo com os autores, um agente econômico em posição dominante poderia aumentar seu poder de mercado por meio de instrumentos de vinculação. Isto porque, ao fechar o mercado para os concorrentes no mercado vinculado a potenciais compradores, tais práticas poderiam reduzir a concorrência neste mercado. ${ }^{264}$ SALOP afirma, ainda, que as proposições de Chicago somente seriam validas em circunstâncias econômicas muito limitadas e que sua validade pressuporia um número restrito de premissas, nem sempre presentes no mundo real. ${ }^{265}$

WHINSTON, em artigo datado de 1990, referente às práticas de venda casada (tying) buscou demonstrar que a teoria da alavancagem seria plausível se duas condições estivessem presentes: a primeira condição seria que o mercado vinculado estivesse sujeito a economias de escala e a segunda condição seria que a alavancagem induzisse à exclusão de rivais ou impedisse a entrada de concorrentes no mercado vinculado, resultando, desta forma, em aumento de poder de mercado no mercado vinculado. ${ }^{266}$ CARLTON e WALDMAN, ainda, propuseram modelos de acordo com os quais buscavam demonstrar práticas de venda casada (tying) poderiam estender o poder de monopólio a mercados adjacentes e, ainda, a preservar uma posição dominante existente. ${ }^{267} \mathrm{Em}$ linhas gerais, se há uma redução de agentes econômicos no mercado vinculado ou, ainda, se os ofertantes neste mercado venderem o produto vinculado somente para aqueles consumidores/compradores que não adquirem o produto vinculante, há inevitavelmente uma redução de concorrência no mercado vinculado e potencial exclusão de ofertantes neste mercado.

HOVENKAMP explica, ainda, que a Escola de Chicago, ao contestar a leverage doctrine, tinha uma visão de que os mercados operavam de forma excessivamente simples e, desta forma, a única consideração a ser feita seria se um agente econômico em posição

\footnotetext{
${ }^{264}$ GAVIL, Andrew I; KOVACIC, William E.; BAKER, Jonathan B. Antitrust Law in Perspective: Cases, Concepts and Problems in Competition Policy. American Casebook Series, Thompson West, Second Edition, 2008 , p. 811.

${ }^{265}$ SALOP, Steven C. Economic Analysis of Exclusionary Vertical Conduct: Where Chicago has Overshot the Mark. In: PITOFSKY, Robert (Ed.). How the Chicago School Overshot the Mark. The Effect of Conservative Economic Analysis of U.S. Antitrust, Oxford University Press, 2008, p. 145.

${ }^{266}$ WHINSTON, Michael. Tying, Foreclosure, and Exclusion. In: American Economic Review, v. 80, p. 837, 1990.

${ }^{267}$ CARLTON, Denis; WALDMAN, Michael. The Strategic Use of Tying to Preserve and Create Market Power in Evolving Industries, In: Rand Journal of Economics, v. 33 (2002).
} 
dominante poderia estender seu poder de mercado ao relacionar dois mercados conjuntamente. Quando as preocupações fossem colocadas de forma mais ampla, no entanto, as proposições de Chicago perderiam muito de sua força. ${ }^{268}$

Para exemplificar a situação de excesso de simplicidade das proposições de Chicago neste particular, HOVENKAMP faz referência a uma das muitas discussões envolvendo as condutas da Microsoft com relação à vinculação de sua plataforma (Windows) ao seu Internet browser (Internet Explorer). A preocupação acerca da vinculação, por parte da Microsoft, entre o Windows (mercado de plataforma = mercado vinculante) e o seu Internet Explorer (mercado de browser $=$ mercado vinculado) não seria a de que a Microsoft seria capaz de extrair "duplo lucro de monopólio" ao vincular os dois produtos; a preocupação seria a de que a Microsoft poderia utilizar a sua posição dominante no mercado de plataformas para restringir inovação no mercado de browser e, portanto, prevenir o surgimento de outros concorrentes neste mercado. ${ }^{269}$

A teoria, portanto, sobreviveu às críticas de Chicago, não obstante seus questionamentos terem tido um impacto na literatura pós-Chicago, com o desenvolvimento e qualificação de algumas de suas premissas.

\subsection{A exclusão e os preços predatórios}

Com relação à prática de preços predatórios, a abordagem pré-Chicago considerava que agentes econômicos em posição dominante poderiam adotar condutas predatórias e ser bem sucedidos em suas estratégias de predação em muitas situações, excluindo rivais do mercado. Conforme artigo de McGEE de 1958, a maioria dos casos envolvendo preços predatórios na era pré-Chicago eram decididos pelos tribunais norte-americanos contra os agentes "predadores". 270

Teóricos ligados à Escola de Chicago contestaram fortemente a visão então predominante acerca de condutas de preços predatórios. De forma geral, eles consideravam que a estratégia de praticar preços abaixo de custo para excluir rivais seria irracional,

\footnotetext{
${ }^{268}$ HOVENKAMP, Herbert. The Antitrust Enterprise: principle and execution. Harvard University Press, Cambridge, Massachusetts; London, England, 2005, p. 35.

${ }^{269}$ HOVENKAMP, Herbert. The Antitrust Enterprise: principle and execution. Harvard University Press, Cambridge, Massachusetts; London, England, 2005, p. 35.

${ }^{270}$ McGEE, John S. Predatory Price Cutting: The Standard Oil (N.J.) Case. Journal of Law and Economics, Vol. 1 (Oct., 1958), pp. 137-169.
} 
porque o agente dominante dificilmente conseguiria reaver suas perdas. ${ }^{271}$ No já mencionado artigo McGEE, o autor examinou cuidadosamente um dos casos clássicos da jurisprudência norte-americana envolvendo condutas de exclusão, o caso Standard Oil, de 1911, e concluiu que o caso não apresentava indícios de predação. ${ }^{272}$ Mais tarde, GRANITZ e KLEIN reforçaram o argumento e argumentaram que o caso Standard Oil seria melhor compreendido como uma forma de exclusão não ligada a preço, e não uma forma de exclusão relacionada à prática de preços predatórios. ${ }^{273}$

A Escola de Chicago considerava que estratégias de preços predatórios dificilmente seriam bem sucedidas, pois seriam muito arriscadas: poderiam não causar a saída de concorrentes do mercado e, mesmo que causassem, o agente predador teria que reaver as perdas sofridas durante o período da "predação". Isto, no entanto, somente seria possível se o agente dominante aumentasse seus preços após a saída dos concorrentes. Este aumento de preços, por sua vez, faria com que novos agentes econômicos entrassem no mercado e restaurassem um nível de preços competitivo. De outra forma, preços abaixo de custo seriam um indicativo de concorrência legítima e, portanto, não deveriam ser coibidos. ${ }^{274}$

Esta linha de argumentação levou os tribunais norte-americanos a adotar algumas regras que dificultariam a demonstração de que condutas de preços predatórios seriam anticompetitivas. De acordo com estas regras, os preços praticados por um agente econômico em posição dominante não seriam predatórios caso estivessem acima de alguma

\footnotetext{
271 "Any realistic theory of predation recognizes that the predator as well as his victims will incur losses during the fighting, but such a theory supposes it may be a rational calculation for the predator to view the losses as an investment in future monopoly profits (where rivals are to be killed) or in the future undisturbed profits (where rivals are to be disciplined). The future flow of profits, appropriately discounted, must then exceed the present size of the losses. So stated, there seems nothing inherently impossible in the theory. The issue is the probability of the occurrence of predation and the means available for detecting it." BORK, Robert H. The Antitrust Paradox. A Policy at War with Itself. The Free Press, 1993.

${ }^{272}$ McGEE, John S. Predatory Price Cutting: The Standard Oil (N.J.) Case. Journal of Law and Economics, Vol. 1 (Oct., 1958), pp. 137-169.

${ }^{273}$ GRANITZ, Elizabeth; KLEIN, Benjamin. Monopolization by "Raising Rivals Costs": The Standard Oil Case. In: Journal of Law and Economics, v. 39, 1986.

${ }^{274}$ Conforme resumo de MONTI (MONTI, Giorgio. EC Competition Law. Cambridge University Press, 2007, p. 68) e explicação de BAKER (BAKER, Jonathan B.. Preserving a Political Bargain: The Political Economy of the Non-Interventionist Challenge to Monopolization Enforcement. In: Antitrust Law Journal, v. 76, Issue 3, 2010, p. 610). Vale notar que POSNER, outro teórico ligado à Escola de Chicago, reconhecia que a estratégia de preços predatórios em um mercado poderia ser lucrativa se detivesse a entrada de outros concorrentes ou reduzisse a concorrência em outros mercado. POSNER, Richard. Antitrust Law, 2 ed., 2001, p. 208-210.
} 
medida de custo. ${ }^{275}$ Além disto, seria necessário demonstrar que seria lucrativo para o agente econômico em posição dominante adotar uma estratégia que lhe seria desvantajosa inicialmente e, ainda, que ele seria capaz de reaver suas perdas em um momento posterior. Como resultado destas regras, os casos referentes a preços predatórios tornaram-se cada vez mais difíceis de serem demonstrados e decididos contra os agentes supostamente "predadores".

Conforme aponta KOVACIC, a evolução da doutrina e da política norte-americana com relação às estratégias de preços predatórios adotadas por agentes econômicos em posição dominante seria um exemplo da influência não somente da Escola de Chicago, mas também - e talvez principalmente - da "nova" Escola de Harvard. ${ }^{276}$ KOVACIC atribui a mudança na abordagem de preços predatórios a um artigo dos autores AREEDA e TURNER, publicado em 1975, que propôs a utilização da relação entre os preços praticados pelos agentes em posição dominante aos seus custos variáveis, como forma de definir a legalidade da estratégia de preços. ${ }^{277}$

KOVACIC aponta, ainda, que um dos objetivos de AREEDA e TURNER ao desenvolver um teste para preços predatórios relacionado aos custos do agente dominante seria mudar o foco da análise ao avaliar argumentos de exclusão, que, em algumas situações, levava em consideração a intenção do agente, e não os efeitos das práticas. HOVENKAMP também aponta que nas décadas que sucederam a publicação do artigo, os padrões sugeridos pelos dois autores passaram a ser o ponto de partida de discussões sobre a prática de preços abaixo de alguma medida de custo. ${ }^{278}$

Dois casos decididos pela Suprema Corte dos Estados Unidos nas décadas de 1980 e 1990 são frequentemente mencionados como exemplificativos desta tendência a uma

\footnotetext{
${ }^{275}$ Esta medida de custo usualmente seria a de custos médios variáveis (average variable costs), conforme proposta por AREEDA e TURNER. AREEDA, Philip; TURNER, Donald F. Predatory Pricing and Practices under Section 2 of the Sherman Act. In: Harvard Law Review, v. 88, p. 697, 1975.

${ }^{276}$ KOVACIC, William. The Intelectual DNA of Modern U.S. Competition Law for Dominant Firm Conduct: The Chicago/Harvard Double Helix. In: Columbia Business Law Review, V. 1, 2007, p. 42 e seguintes.

${ }^{277}$ O artigo ao qual KOVACIC se refere foi publicado em 1975, na Harvard Law Review. AREEDA, Philip; TURNER, Donald F. Predatory Pricing and Practices under Section 2 of the Sherman Act. In: Harvard Law Review, v. 88, p. 697, 1975.

${ }^{278}$ HOVENKAMP, Herbert. The Law of Exclusionary Pricing. In: Competition Policy International, v. 21, 2006.
} 
análise mais cuidadosa e favorável aos supostos agentes econômicos "predadores": o caso Matsushita, decidido em $1986^{279}$, e o caso Brooke Group ${ }^{280}$, decidido em 1993.

Conforme relato de PAGE e LOPATKA, o caso Matsushita envolvia a acusação por parte de fabricantes norte-americanos de que empresas japonesas estariam adotando condutas de preços predatórios, que seriam subsidiadas pela cobrança de preços cartelizados no mercado japonês. A Suprema Corte dos Estados Unidos considerou que a alegação de predação não faria sentido econômico porque as empresas japonesas não teriam como esperar obter lucros no mercado dos Estados Unidos que compensassem os anos de perdas alegadas pelos autores. A Suprema Corte indicou, ainda, que a redução de preços é muito frequentemente a própria essência da concorrência e, portanto, erros de inferência nestes casos seriam especialmente custosos, porque tenderiam a neutralizar justamente condutas que as normas antitruste seriam designadas a proteger. ${ }^{281}$

Já no caso Brooke Group, decidido em 1993, a Suprema Corte decidiu que os autores que alegassem preços predatórios deveriam demonstrar não somente que os preços praticados pelos agentes dominantes estariam abaixo de uma medida apropriada de custo, mas também que deveria haver uma probabilidade - baseada em evidências - de que os agentes supostamente predadores poderiam reaver suas perdas durante o período da alegada predação ao cobrar preços de monopólio no futuro. ${ }^{282}$

Conforme apontam PAGE e LOPATKA, estas orientações tornaram mais difícil demonstrar a ocorrência de preços predatórios na prática. Assim, a imposição de ônus de prova aos autores em processos judiciais (agentes governamentais ou privados) envolvendo argumentos de preços predatórios seria uma reorientação explícita da lei antitruste em direção à proteção dos interesses dos consumidores. Prejuízos a rivais em decorrência destas práticas seriam relevantes somente se causassem prejuízos aos consumidores. Como a redução de preços é geralmente benéfica a consumidores, preços predatórios deveriam ser

\footnotetext{
${ }^{279}$ Matsushita Elec. Indus. Corp. v. Zenith Radio Corp., 475 U.S, 574 (1986).

${ }^{280}$ Brook Group Ltda. v. Brown \& Williamson Tobacco Corp., 113 S. Ct. 2578 (1993).

${ }^{281}$ PAGE, William H.; LOPATKA, John E. The Microsoft Case: Antitrust, High Technology, and Consumer Welfare. The University of Chicago Press, 2007, p. 18.

${ }^{282}$ A descrição aqui é feita também com base em PAGE e LOPATKA. PAGE, William H.; LOPATKA, John E. The Microsoft Case: Antitrust, High Technology, and Consumer Welfare. The University of Chicago Press, 2007, p. 18. Uma análise mais detalhadas sobre o caso Brooke Group e seus antecedentes pode ser encontrada em BAKER, Jonathan B. Predatory Pricing after Brooke Group: An Economic Perspective. In: Antitrust Law Journal, v. 62, 1994, p. 585-603.
} 
considerados ilegais somente se resultassem em preços de monopólio, e a definiç̧ão acerca de sua ilicitude deveria evitar inclusão errônea de práticas que poderiam ser vantajosas aos consumidores.

Vale notar que a linha pós-Chicago concebe a prática de preços predatórios como uma estratégia racional, em determinadas circunstâncias. Um dos argumentos trazidos pelos teóricos pós-Chicago, conforme explicado por BAKER, seria de que a prática de preços predatórios poderia configurar uma estratégia designada por um agente econômico em posição dominante para criar uma "reputação de comportamento predatório", que faria com que concorrentes e novos entrantes se intimidassem com a perspectiva de uma campanha predatória agressiva. Como resultado, os concorrentes não tentariam concorrer de forma muito agressiva e entrantes potenciais poderiam resistir à entrada. ${ }^{283}$ Neste sentido, a "reputação de comportamento predatório" de determinados agentes dominantes poderia funcionar como uma forma de barreira à entrada. ${ }^{284}$

Ainda, outra possibilidade de plausibilidade da prática de preços predatórios relacionada à linha Pós-Chicago ${ }^{285}$ seria a chamada teoria de recuperação multimercado (multimarket recoupment theory). De acordo com a explicação de BAKER, a recuperação das perdas possivelmente decorrentes de preços predatórios poderia ocorrer em um mercado diferente (seja do ponto de vista do produto ou do ponto de vista geográfico) do mercado em que a predação teria ocorrido; sob este prisma, a estratégia de preços predatórios também seria plausível, de acordo com a linha Pós-Chicago.

HOVENKAMP anota que casos envolvendo práticas convencionais de preços predatórios nos Estados Unidos tornaram-se cada vez mais difíceis de serem decididos contra os supostos predadores, muito em razão da aceitação dos testes propostos por AREEDA e TURNER mencionados acima. HOVENKAMP observa, no entanto, que outros tipos de casos envolvendo práticas de exclusão ligadas a preço (tais como discussões sobre

\footnotetext{
${ }^{283}$ Neste sentido, ver BAKER: "The primary new theoretical development is the identification of a new type of predator, which cuts price in a handful of markets and creates a reputation as an aggressive competitor. This type of predator recoups the costs of predation not merely in the markets in which it engaged in a price war, but also in other markets to which its reputation has spread, by intimidating rivals in those markets to act less aggressively toward it." BAKER, Jonathan B. Predatory Pricing after Brooke Group: An Economic Perspective. In: Antitrust Law Journal, v. 62, 1994, p. 592.

${ }^{284}$ WHISH, Richard. Competition Law. 6th Edition, LexisNexis Buttersworths, 2008, p. 730.

${ }^{285}$ BAKER, Jonathan B. Predatory Pricing after Brooke Group: An Economic Perspective. In: Antitrust Law Journal, v. 62, p. 595 e seguintes.
} 
descontos e outros arranjos ligados a preço) passaram a se tornar mais comuns no cenário norte-americano, gerando teorias alternativas à teoria convencional de preços predatórios. ${ }^{286}$ Alguns destes arranjos menos convencionais serão tratados no próximo capítulo.

\subsection{A exclusão e as práticas não ligadas a preço}

Alguns autores norte-americanos costumam fazer uma distinção entre condutas de exclusão ligadas a preços e condutas de exclusão não ligadas a preço. ${ }^{287}$ Estas últimas envolvem restrições verticais como venda casada, exclusividade (exclusive dealing) e recusa de venda.

Nos próximos itens, tratamos das contribuições teóricas ligadas aos comportamentos tendentes à exclusão não relacionados a preço. Neste contexto, trataremos brevemente da exclusividade e da recusa unilateral de contratar, dois tipos de condutas que estão intimamente relacionadas e cujo debate teórico-econômico pode ser compreendido no contexto de discussões ligadas à Escola de Chicago e do aumento dos custos dos rivais, contribuição usualmente associada aos desenvolvimentos Pós-Chicago.

\subsubsection{Exclusividade, recusa unilateral de contratar e a Escola de Chicago}

Como já tivemos a oportunidade de tratar em outro trabalho ${ }^{288}$, a partir do final da década de 1960 e início da década de 1970, os teóricos ligados à Escola de Chicago passaram a questionar a plausibilidade dos argumentos ligados à obstrução de mercado e a enfatizar as eficiências ligadas aos acordos de exclusividade. ${ }^{289}$ BORK, um dos principais teóricos ligados à Escola de Chicago, afirmava que acordos de exclusividade não poderiam

\footnotetext{
${ }^{286}$ HOVENKAMP, Herbert. The Law of Exclusionary Pricing. In: Competition Policy International, v. 2, n. 1. Spring, 2006, p. 21.

${ }^{287}$ GAVIL, Andrew I; KOVACIC, William E.; BAKER, Jonathan B. Antitrust Law in Perspective: Cases, Concepts and Problems in Competition Policy. American Casebook Series, Thompson West, Second Edition, 2008. SALOP, Steven C. Economic Analysis of Exclusionary Vertical Conduct: Where Chicago has Overshot the Mark. In: PITOFSKY, Robert (Ed.). How the Chicago School Overshot the Mark. The Effect of Conservative Economic Analysis of U.S. Antitrust, Oxford University Press, 2008, p. 142.

${ }^{288}$ CORRÊA, Mariana Villela. Exclusividade e Direito da Concorrência. Dissertação de Mestrado apresentada ao Departamento de Direito Comercial, Universidade de São Paulo, Faculdade de Direito, São Paulo, 2008.

${ }^{289}$ Conforme explicação de MOTTA, Massimo. Competition Policy: Theory and Practice. Cambridge University Press, 2004, p. 363.
} 
produzir efeitos anticoncorrenciais e que deveriam geralmente ser considerados lícitos. ${ }^{290}$ BORK considerava que o tratamento dado aos acordos de exclusividade à época de seu Antitrust Paradox (originalmente publicado em 1978) era muito severo, uma vez que muita ênfase era dada à questão da obstrução de mercado e poucas considerações eram feitas acerca de eficiências. Como resultado, acordos eficientes estariam sendo equivocadamente considerados ilícitos.

Os teóricos ligados à Escola de Chicago argumentavam que a exclusão de concorrentes por meio de acordos de exclusividade não seria lucrativa aos fornecedores. ${ }^{291}$ Para que um acordo de exclusividade fosse firmado entre um fornecedor e um comprador, o acordo deveria trazer algum benefício ao comprador. Nesse sentido, um comprador racional não estaria disposto a aceitar um acordo que o obrigasse a adquirir exclusivamente de um determinado fornecedor, caso outro fornecedor mais eficiente estivesse disposto a entrar no mercado.

Conforme BORK, ainda, caso um fornecedor pretendesse utilizar os acordos para obter poder de mercado, fornecedores rivais poderiam oferecer melhores condições aos compradores e, dessa forma, impedir que a estratégia obtivesse sucesso. Um fornecedor que pretendesse utilizar acordos de exclusividade precisaria oferecer vantagens aos seus compradores para convencê-los a aceitar tais acordos. Estas vantagens oferecidas pelos fornecedores - muitas vezes, em forma de descontos - seriam simplesmente uma forma de concorrência; nada impediria que outros fornecedores oferecessem os mesmos descontos ou as mesmas vantagens com o objetivo de obter a exclusividade dos compradores. ${ }^{292}$

Mesmo quando um fornecedor já detivesse poder de mercado, este não conseguiria utilizar estes contratos para manter ou aumentar o seu poder de mercado. Um fornecedor que já detivesse poder de mercado seria forçado a cobrar por seus produtos somente o que o mercado pudesse suportar. Para cobrar um preço de monopólio e impor um acordo de exclusividade, o fornecedor seria forçado a cobrar um preço inferior ao nível que seria

290 "Exclusive dealing, being a form of vertical integration, creates efficiencies and does not create restriction of output. It should, therefore, generally be lawful." BORK, Robert H. The Antitrust Paradox. A Policy at War with Itself. The Free Press, 1993, p. 303.

${ }^{291}$ WHINSTON, Michael D. Lectures on Antitrust Economics. The Cairoli Lectures, 2006, p. 137.

${ }^{292}$ O resumo das proposições de BORK é feito aqui a partir da análise e descrição de MEESE. MEESE, Alan J. Exclusive Dealing, The Theory of the Firm, and Raising Rival's Costs: Toward a New Synthesis. In: The Antitrust Bulletin, v. 50, n. 3, Fall 2005, p 394. 
maximizador de seus lucros. Esta redução no seu preço neutralizaria qualquer possibilidade de aumento de poder mercado que estes acordos pudessem produzir. Assim, mesmo agentes com poder de mercado não o poderiam aumentar pelo estabelecimento destes acordos.

Partindo da premissa de que fornecedores com poder de mercado não poderiam utilizar acordos de exclusividade para ganhar ou aumentar seu poder de mercado, os autores da Escola de Chicago deduzem que a única motivação possível para que fornecedores pretendessem firmar tais acordos estaria ligada às eficiências decorrentes dos acordos. Se fornecedores investiam recursos na negociação e no monitoramento destes acordos, sem qualquer possibilidade de prejudicar a concorrência, deveriam estar buscando minimizar seus custos com o objetivo de melhor concorrer com seus rivais. ${ }^{293}$

Em resumo, o argumento da Escola de Chicago enfatizava que seria pouco provável que um fornecedor firmasse acordos de exclusividade com o objetivo de monopolizar o mercado e que motivações pró-concorrencias frequentemente estariam por trás destes acordos.

Com relação à prática de recusa unilateral de contratar, BORK considerava que a presunção acerca da liberdade de contratar de um determinado agente econômico deveria ser mais ampla do que o padrão então existente nos Estados Unidos nos casos relacionados a recusas unilaterais de negociação. BORK reconheceu que ilícitos de monopolização relacionados à recusa de negociação eram difíceis de distinguir de situações lícitas de exclusividade. $^{294}$ Ainda, conforme BORK, quando houvesse um potencial argumento de eficiência ligado à casos envolvendo recusa de negociação e não houvesse demonstração clara de que o propósito da recusa seria predatório, os tribunais deveriam, de forma geral,

\footnotetext{
${ }^{293}$ Conforme MEESE: "If firms could not use such agreements to enhance their gains from market power, Chicagoans said, the contracts must produce benefits...After all, it was said, if firms expanded resources negotiating and enforcing such agreements, without any prospect of harming consumers, then they must be attempting at least to minimize their costs so as to better compete with rivals." MEESE, Alan J. Exclusive Dealing, The Theory of the Firm, and Raising Rival's Costs: Toward a New Synthesis. In: The Antitrust Bulletin, v. 50, n. 3, Fall 2005, p. 394. A este respeito, ainda, ver GAVIL, Andrew; KOVACIC, William E.; BAKER, Jonathan B. Antitrust Law in Perspective: Cases, Concepts and Problems in Competition Policy. American Casebook Series, Thompson West, 2002, p. 734. Vale notar que, enquanto BORK considerava que acordos de exclusividade não poderiam produzir efeitos anticoncorrenciais, POSNER (outro teórico ligado à Escola de Chicago) admite que, em raros casos, estes efeitos seriam possíveis, apesar de argumentar que a exclusão seria "virtualmente impossível". MOTTA, Massimo. Competition Policy: Theory and Practice. Cambridge University Press, 2004, p. 364.

${ }^{294}$ BORK, Robert H. The Antitrust Paradox. A Policy at War with Itself. The Free Press, 1993, p. 344.
} 
considerar a recusa legítima, uma vez que a "predação" por meio de uma recusa de contratar seria muito improvável. ${ }^{295}$

Ainda, conforme explicação de SAMPAIO sobre recusas unilaterais de contratar, o entendimento de POSNER, outro teórico ligado à Escola de Chicago, considera que as recusas de contratar "têm difícil regramento coativo pelo juiz, pois obrigar duas partes a contratarem uma relação negocial contínua pressuporia uma supervisão judicial sobre ações empresariais, objeto que não se enquadra dentre as competências do Poder Judiciário." 296

\subsubsection{A exclusão e a teoria de aumento dos custos dos rivais (raising rivals costs)}

De forma geral, a compreensão do potencial de exclusão das práticas não ligadas a preço - tais como a exclusividade e a recusa unilateral de contratar - ganharam novo fôlego com as contribuições trazidas pela linha teórica conhecida como a teoria do aumento dos custos dos rivais (raising rivals costs), geralmente associada ao movimento pós-Chicago. Como veremos mais adiante, a teoria de aumento dos custos dos rivais também tem relevância com relação à análise de outras práticas menos convencionais, muitas das quais podem ter algum componente ligado a preço (Capítulo IV).

A teoria do aumento dos custos dos rivais foi desenvolvida por KRATTENMAKER, SALOP e SCHEFFMAN ${ }^{297}$ e, em linhas gerais, foi capaz de trazer uma explicação econômica mais robusta acerca dos efeitos econômicos do fechamento de mercado, associados especialmente à exclusividade, à venda casada e à recusa de venda. Conforme explica HOVENKAMP, as teorias relacionadas ao aumento dos custos dos rivais explicam que determinadas práticas são mais facilmente compreendidas não como formas de destruir rivais, mas como formas de tornar seus custos de produção ou distribuição mais altos. ${ }^{298}$ Ainda conforme HOVENKAMP, situações em que rivais permanecem no mercado mas

\footnotetext{
${ }^{295}$ BORK, Robert H. The Antitrust Paradox. A Policy at War with Itself. The Free Press, 1993, p. 345.

${ }^{296}$ POSNER, Richard. Antitrust Law. Chicago: The University of Chicago Press, 2001, p. 242, apud. SAMPAIO, Patrícia Regina Pinheiro. Direito da Concorrência e Obrigações de Contratar, Rio de Janeiro, Editora Elsevier, 2009, p. 113-114.

${ }^{297}$ KRATTENMAKER, Thomas G.; SALOP, Steven C. Anticompetitive Exclusion: Raising Rivals Cost to Achieve Power over Price. In: Yale Law Journal, v. 96, 1986, p. 209; SALOP, Steven C. ; SCHEFFMAN, David T. Raising Rival's Costs. In: American Economic Review, v. 73, 1983, p. 267.

${ }^{298}$ HOVENKAMP, Herbert. Post-Chicago Antitrust: A Review and Critique. In: Columbia Business Law Review, 2001, p. 321.
} 
têm seus custos aumentados são mais prováveis de ocorrer e existir em maior variedade do que situações em que rivais são destruídos. ${ }^{299}$

Em artigo datado de $1986^{300}$, KRATTENMAKER e SALOP criticam tanto a abordagem tradicional da jurisprudência norte-americana pré-Chicago quanto a abordagem da Escola de Chicago com relação aos potenciais efeitos de fechamento de mercado de determinadas práticas. Os autores argumentam que, para determinar se uma prática vertical é anticoncorrencial, seria necessário verificar não a "obstrução de mercado" em si mesma, mas a tendência que tal prática teria em aumentar os custos dos rivais; o aumento dos custos dos rivais, por sua vez, poderia facilitar o exercício de poder sobre preço no mercado de fornecimento. Em resumo, KRATTENMAKER e SALOP argumentam que a teoria da obstrução de mercado - que justificava uma abordagem conservadora no período préChicago - poderia estar correta, porém não pelos motivos inicialmente propostos. ${ }^{301}$

KRATTENMAKER e SALOP reconhecerem que determinados ajustes poderiam ter justificativas de eficiência. Argumentam, contudo, que tais práticas poderiam ser anticoncorrenciais, quando impusessem custos aos rivais, que não seriam incorridos pelo fornecedor "predador". Para explicar este ponto, KRATTENMAKER e SALOP utilizam o seguinte exemplo. Um fornecedor pode distribuir seus produtos por intermédio de dois canais de distribuição alternativos, sendo um destes canais claramente mais eficiente e menos custoso do que outro. Ao firmar acordos por meio dos quais os distribuidores no canal mais eficiente se comprometem a somente comercializar produtos de determinado fornecedor, este fornecedor pode forçar seus rivais a utilizar o canal de distribuição mais custoso. Ao fazer isto, o fornecedor "predador" aumenta o custo dos seus rivais. Esta estratégia pode resultar na saída de um rival do mercado ou sua permanência no mercado, porém com o possível aumento de seus preços (em razão dos custos mais elevados). Em qualquer um dos casos, o fornecedor "predador" terá atingido "poder sobre preços": ao utilizar custos menores, pode aumentar os custos dos rivais e aumentar seus próprios lucros.

${ }^{299}$ HOVENKAMP, Herbert. The Harvard and Chicago School and the Dominant Firm. In: PITOFSKY, Robert (Ed.). How the Chicago School Overshot the Mark. The Effect of Conservative Economic Analysis of U.S. Antitrust, Oxford University Press, 2008, p. 117.

${ }^{300}$ KRATTENMAKER, Thomas G.; SALOP, Steven C. Anticompetitive Exclusion: Raising Rivals Cost to Achieve Power over Price. In: Yale Law Journal, v. 96, 1986, p. 209.

${ }^{301}$ No original: "foreclosure theory may still be correct, but no for the reasons originally advanced." KRATTENMAKER, Thomas G.; SALOP, Steven C. Anticompetitive Exclusion: Raising Rivals Cost to Achieve Power over Price. In: Yale Law Journal, v. 96, 1986, p. 234. 
O principal argumento proposto pela teoria do aumento dos custos dos rivais, portanto, é que determinadas estratégias seriam mais plausíveis se consideradas como formas de aumentar os custos dos rivais e não como forma de totalmente excluí-los do mercado. Nesse contexto, diversas práticas verticais poderiam ser explicadas como formas de aumentar os custos de produção e distribuição de fornecedores rivais, ao impedir que eles obtivessem economias de escala, ou ao impedir o seu acesso a canais de distribuição mais eficientes. $^{302}$

Em síntese, a teoria do aumento dos custos dos rivais propõe que o foco da investigação antitruste em casos relacionados a ilícitos de exclusão deve ser no seu impacto nos custos dos rivais - quando a prática impuser custos em seus rivais, um fornecedor pode adquirir poder sobre preço. Os autores ligados a esta linha teórica, portanto, deixam de confiar em inferências de danos concorrenciais meramente a partir da existência de obstrução de mercado e deslocam a análise para o impacto nos custos dos rivais. ${ }^{303}$

Em outras palavras, as estratégias de aumento de custos dos rivais geralmente envolvem uma tentativa de um agente econômico em posição dominante de criar desvantagens para seus rivais ao aumentar seus custos. As estratégias de aumento de custos dos rivais podem ser lucrativas mesmo que não haja exclusão de concorrentes uma vez que é melhor concorrer contra rivais que tenham maiores custos do que contra concorrentes que tenham custos menores. ${ }^{304}$

HOVENKAMP aponta que a teoria do aumento dos custos dos rivais é uma útil, porém incompleta, definição do que seriam condutas de exclusão ilícita. Algumas práticas que aumentam os custos dos rivais, tais como inovações que, ou prejudicam vendas de rivais, ou os forçam a inovar como resposta, também podem ser benéficas. Portanto, a

\footnotetext{
${ }^{302}$ HOVENKAMP, Herbert. Post-Chicago Antitrust: A Review and Critique. In: Columbia Business Law Review, 2001, p. 318 e p. 321.

${ }^{303}$ KRATENMAKER e SALOP discutem o que chamam de "real foreclosure". KRATTENMAKER, Thomas G.; SALOP, Steven C. Anticompetitive Exclusion: Raising Rivals Cost to Achieve Power over Price. In: Yale Law Journal, v. 96, 1986, p 236-238. A este respeito, ver também GAVIL, Andrew; KOVACIC, William E.; BAKER, Jonathan B. Antitrust Law in Perspective: Cases, Concepts and Problems in Competition Policy. American Casebook Series, Thompson West, 2002, p. 735-736.

${ }^{304}$ Conforme síntese publicada em AMERICAN BAR ASSOCIATION, SECTION OF ANTITRUST LAW. Monopolization and Dominance Handbook, 2011, American Bar Association, p. 35.
} 
teoria do aumento dos custos dos rivais não pode operar, segundo HOVENKAMP, como um teste completo acerca da licitude de condutas tendentes à exclusão. ${ }^{305}$

\section{DISCUSSÕES MAIS RECENTES: PANORAMA}

\subsection{Introdução}

Como tratamos brevemente no capítulo anterior, há atualmente indefinição e controvérsia na teoria econômica em geral acerca de qual a melhor forma de avaliar os efeitos de comportamentos adotados por agentes dominantes tendentes a exclusão de rivais. Ainda, diante da proliferação de novas formas de distribuição tendentes a exclusão, alguns testes vêm sendo sugeridos nos últimos anos, com o objetivo de fornecer subsídios a serem utilizados por tribunais ou por autoridades de defesa da concorrência na análise destes comportamentos. ${ }^{306}$ A seguir, trataremos, de forma resumida, dos testes referidos com mais frequência pela literatura antitruste recente. Estes "testes" tem alguma repercussão nas discussões presentes na Europa e encontram-se, algumas vezes, na jurisprudência nacional acerca de condutas de exclusão.

\subsection{Testes focados no bem estar do consumidor}

Conforme explica HAWK, nos Estados Unidos, nas últimas décadas, o bem estar do consumidor tem sido considerado o único, se não o mais importante, aspecto a ser considerado na análise dos ilícitos de monopolização, nos termos da Seção 2 do Sherman Act. ${ }^{307}$ Neste sentido, o autor explica que uma série de testes vêm sendo sugeridos com foco no bem estar do consumidor.

De acordo com HAWK, os testes relacionados ao bem estar do consumidor costumam focar nos efeitos que determinadas práticas têm nos consumidores e em suas

\footnotetext{
${ }^{305}$ HOVENKAMP, Herbert. The Harvard and Chicago School and the Dominant Firm. In: PITOFSKY, Robert (Ed.). How the Chicago School Overshot the Mark. The Effect of Conservative Economic Analysis of U.S. Antitrust, Oxford University Press, 2008, p. 117.

${ }^{306}$ A respeito dos testes propostos, de forma geral, afirma HOVENKAMP, em recente artigo: "The recent literature on section 2 has been preoccupied to the point of obsession with the formulation of a single test for exclusionary conduct." HOVENKAMP, Herbert. The Harvard and Chicago School and the Dominant Firm. In: PITOFSKY, Robert (Ed.). How the Chicago School Overshot the Mark. The Effect of Conservative Economic Analysis of U.S. Antitrust, Oxford University Press, 2008, p. 114.

${ }^{307}$ HAWK, Barry E. Article 82 and Section 2: Abuse and Monopolization Conduct. In: Issues in Competition Law and Policy, Volume II, 2008, ABA Section of Antitrust Law, p. 877.
} 
eficiências, ao passo que outros testes focam-se em aspectos relativos ao agente que ocupa posição dominante e seus comportamentos, bem como a aspectos relativos aos concorrentes destes agentes.

VICKERS propõe um teste de acordo com o qual há abuso de posição dominante quando a conduta em discussão tem o efeito de aumentar preços ou restringir a oferta, restringir inovação ou restringir qualidade. ${ }^{308}$ SALOP, por sua vez, propõe um teste que se foca diretamente nos efeitos anticompetitivos no bem estar do consumidor, qual seja, preços de mercado e qualidade de produtos, incluindo efeitos de preço e qualidade resultantes de inovações. Neste sentido, uma conduta seria ilegal se reduzisse a concorrência sem criar um aumento suficiente de desempenho do agente econômico em posição dominante que compensasse os efeitos adversos potenciais nos preços e impedisse o bem estar do consumidor. ${ }^{309}$

HAWK explica, ainda, que os tribunais norte-americanos, por vezes, aplicaram um método de acordo com o qual seria necessário demonstrar os efeitos anticompetitivos de um determinado comportamento. Estabelecidos tais efeitos pelos autores da acusação (que, como sabemos, podem ser as autoridades governamentais ou agentes privados), o ônus da prova seria transferido ao agente econômico dominante (acusado), que poderia oferecer provas de justificativas pró-competitivas. Se a justificativa apresentada pelo agente econômico dominante não for contestada, o autor então deveria demonstrar que o prejuízo anticoncorrencial compensaria os benefícios pró-competitivos. ${ }^{310}$ De acordo com HAWK, esta abordagem teria sido adotada num dos casos envolvendo a Microsoft, iniciado pelo governo norte-americano. ${ }^{311}$ GAVIL observa, no entanto, que foram poucos os casos em que os tribunais norte-americanos teriam feito a análise da compensação dos benefícios de eficiência. $^{312}$

\footnotetext{
${ }^{308}$ VICKERS, John. Abuse of Market Power. In: The Economic Journal, 115 (June), F244-F261, p. 244.

${ }^{309}$ SALOP, Steven C. Exclusionary Conduct, Effect on Consumers, and the Flawed Profit-Sacrifice Standard. In: Antitrust Law Journal, v. 73, n. 2, 2006.

${ }^{310}$ HAWK, Barry E. Article 82 and Section 2: Abuse and Monopolization Conduct. In: Issues in Competition Law and Policy, Volume II, 2008, ABA Section of Antitrust Law, p. 879.

${ }^{311}$ United States v. Microsoft Corp., 253 F. 3d 34, 58 (D.C. Cir 2001).

${ }^{312}$ GAVIL, Andrew I. Exclusionary Distribution Strategies by Dominant Firms: Striking a Better Balance. In: Antitrust Law Journal, V. 72, 2004.
} 
As críticas relacionadas aos testes focados nos prejuízos ao bem estar do consumidor referem-se à inabilidade dos tribunais em implementá-los, uma vez que, entre outros aspectos, seria difícil mensurar os impactos da conduta contestada em preços, oferta ou qualidade dos produtos. Ainda, outra linha de críticas argumenta que os testes focados no bem estar do consumidor tenderiam identificar "falso-positivos" e que um teste adicional seria necessário, tais como os relativos ao sacrifício de lucros e de ausência de sentido econômico, tratados a seguir. ${ }^{313}$

\subsection{Testes focados nas perdas sofridas pelos agentes econômicos dominantes e na racionalidade econômica das condutas contestadas}

Alguns testes têm se focado no sacrifício de lucros sofridos pelos agentes econômicos dominantes cujos comportamentos são questionados. Em linhas gerais, o comportamento seria ilícito se envolvesse o sacrifício de lucros a curto prazo que não seria vantajoso ao agente econômico dominante, a não ser que este pudesse ter algum retorno a longo prazo ao excluir ou disciplinar rivais. ${ }^{314}$ Neste contexto, um comportamento seria ilícito se fosse não lucrativo para o agente dominante e se excluisse rivais, com a possibilidade de recuperar perdas posteriormente.

Esta proposição foi criticada por diversos autores, entre eles, GAVIL, que considera que o teste pode não abarcar condutas de exclusão anticompetitivas que não envolvem algum sacrifício para o agente dominante. ${ }^{315}$ Entre outras críticas, ainda, questiona-se se o "teste de sacrifício de lucros" (profit sacrifice test) seria suficiente ou se seria necessário demonstrar efeitos anticompetitivos do comportamento questionado. MELAMED propõe que, além da demonstração das perdas, seria necessário demonstrar a prova da exclusão e

\footnotetext{
${ }^{313}$ Conforme síntese de HAWK. HAWK, Barry E. Article 82 and Section 2: Abuse and Monopolization Conduct. In: Issues in Competition Law and Policy, Volume II, 2008, ABA Section of Antitrust Law, p. 880. MELAMED, A. Douglas. Exclusive Dealing Agreements and Other Exclusionary Conduct - Are there Unifying Principles? In: Antitrust Law Journal, v. 73, 2005-2006, p. 381-383.

${ }^{314}$ HAWK, Barry E. Article 82 and Section 2: Abuse and Monopolization Conduct. In: Issues in Competition Law and Policy, Volume II, 2008, ABA Section of Antitrust Law, p. 880. MELAMED, A. Douglas. Exclusive Dealing Agreements and Other Exclusionary Conduct - Are there Unifying Principles? In: Antitrust Law Journal, v. 73, 2005-2006, p. 389-395.

315 "The principal flaw of a sacrifice test is its assumption that "predation" is never of concern to the antitrust laws if it is costless....the presence or absence of sacrifice does not make either the defendant's monopoly power or the effects of its conduct on rivals and consumers any more or less probable." GAVIL, Andrew I. Exclusionary Distribution Strategies by Dominant Firms: Striking a Better Balance. In: Antitrust Law Journal, V. 72, 2004, p. 56-58.
} 
de que o comportamento teria permitido o agente econômico aumentar seu poder de mercado, que não teria sido viável de outra forma. ${ }^{316}$ Neste sentido, HAWK argumenta que o "teste de sacrifício de lucros" operaria mais como um filtro do que como um padrão a ser seguido. $^{317}$

Uma objeção adicional ao "teste de sacrifício de lucros" é apresentada por HOVENKAMP. O autor argumenta que inovações são sempre custosas para os agentes econômicos e o seu sucesso pode depender da capacidade de excluir rivais de um determinado mercado. Muitas inovações somente serão bem sucedidas se consumidores substituírem o uso de produtos de determinados fornecedores por versões mais modernas (inovadoras) de um determinado fornecedor. Neste sentido, o teste não faria uma distinção entre o "sacrifício" anticompetitivo do "investimento" pro-competitivo. ${ }^{318}$

Uma variação do "teste de sacrifício de lucros" envolve um teste que avalia o sentido econômico da prática questionada, denominado de "no economic sense test". De acordo com o este teste, se o comportamento de um agente dominante envolve algum tipo de sacrifício a curto prazo, deve-se indagar se, do ponto de vista econômico, seria racional ao agente econômico dominante incorrer neste sacrifício. ${ }^{319}$ Este teste também tem sido criticado, principalmente porque foca-se exclusivamente nos incentivos relacionados ao comportamento do agente econômico dominante, ignorando, portanto, os efeitos do comportamento em rivais e em consumidores. ${ }^{320}$ Além disto, de acordo com SALOP, o teste não oferece precisão ou clareza em sua aplicação. ${ }^{321}$ Finalmente, questiona-se se a prova de um comportamento irracional seria suficiente ou se seria necessário, além da demonstração de ausência de racionalidade econômica do agente, demonstrar efeitos anticompetitivos da prática. WERDEN propõe que o teste deve demonstrar que, além da

\footnotetext{
${ }^{316}$ MELAMED, A. Douglas. Exclusive Dealing Agreements and Other Exclusionary Conduct - Are there Unifying Principles? In: Antitrust Law Journal, v. 73, 2005-2006, p. 389-395.

${ }^{317}$ HAWK, Barry E. Article 82 and Section 2: Abuse and Monopolization Conduct. In: Issues in Competition Law and Policy, Volume II, 2008, ABA Section of Antitrust Law, p. 881.

${ }^{318}$ HOVENKAMP, Herbert. The Harvard and Chicago School and the Dominant Firm. In: PITOFSKY, Robert (Ed.). How the Chicago School Overshot the Mark. The Effect of Conservative Economic Analysis of U.S. Antitrust, Oxford University Press, 2008, p. 115.

${ }^{319}$ WERDEN, Gregory J. Identifying Exclusionary Conduct Under Section 2: The "No Economic Sense" Test. In: Antitrust Law Journal, v. 73, n. 2, 2006, p. 413-433.

${ }^{320}$ GAVIL, Andrew I. Exclusionary Distribution Strategies by Dominant Firms: Striking a Better Balance. In: Antitrust Law Journal, V. 72, 2004, p. 3.

${ }^{321}$ SALOP, Steven C. Exclusionary Conduct, Effect on Consumers, and the Flawed Profit-Sacrifice Standard. In: Antitrust Law Journal, v. 73, n. 2, 2006.
} 
irracionalidade da conduta, seria necessário demonstrar prejuízos aos concorrentes. ${ }^{322}$ Novamente, a exemplo do que foi dito com relação ao teste relativo ao "sacrifício de lucros", HAWK argumenta que teste parece ser mais um filtro para a análise, do que um padrão sugerido a ser seguido. ${ }^{323}$

\subsection{Testes com referência à eficiência de rivais}

A literatura antitruste norte-americana mais recente tem também discutido testes relacionados à capacidade de condutas de agentes econômicos dominantes afetarem concorrentes que fossem igualmente eficientes. O teste, sugerido originalmente por POSNER $^{324}$, sugere que, nos casos em que há alegação de condutas ilícitas de exclusão, os autores deveriam demonstrar não somente que o agente cuja conduta se questiona tem posição dominante, mas também que a conduta questionada tem a probabilidade de excluir do mercado um concorrente tão ou mais eficiente.

GAVIL questiona o teste em diversas bases. Inicialmente, afirma que o teste presume que não poderia haver prejuízo ao bem estar do consumidor em razão da exclusão de um "rival menos eficiente". O autor argumenta que a entrada de um concorrente, ainda que menos eficiente, pode estimular a concorrência e reduzir preços, se um agente econômico está cobrando preços supra-competitivos. Em segundo lugar, GAVIL afirma que seria difícil "traduzir o teste para a prática", uma vez que seria extremamente difícil comparar níveis de eficiência entre diferentes agentes econômicos; a comparação que deveria ser feita, segundo GAVIL, deveria referir-se às eficiências e ineficiências da conduta questionada. Ainda, seria difícil imaginar como o autor de uma acusação de conduta ilícita de exclusão teria informações suficientes para demonstrar que é tão eficiente quanto o agente econômico cuja conduta se questiona. ${ }^{325}$

\footnotetext{
${ }^{322}$ WERDEN, Gregory J. Identifying Exclusionary Conduct Under Section 2: The "No Economic Sense" Test. In: Antitrust Law Journal, v. 73, n. 2, 2006, p. 413-433.

${ }^{323}$ HAWK, Barry E. Article 82 and Section 2: Abuse and Monopolization Conduct. In: Issues in Competition Law and Policy, Volume II, 2008, ABA Section of Antitrust Law, p. 882.

324 "....in every case in which [exclusionary conduct] is alleged, the plaintiff must prove first that the defendant has monopoly power and second that the challenged practice is likely in the circumstances to exclude from the defendant's market an equally or more efficient competitor." POSNER, Richard. Antitrust Law, 2 ed., 2001, p. 194-195.

${ }^{325}$ GAVIL, Andrew I. Exclusionary Distribution Strategies by Dominant Firms: Striking a Better Balance. In: Antitrust Law Journal, V. 72, 2004, p. 58-61.
} 
SALOP também critica o teste e considera que ele não seria adequado para avaliar a licitude de condutas que tendessem a aumentar custos dos rivais. De acordo com o autor, a falha fundamental do teste refere-se ao fato de que concorrentes menos eficientes ou potenciais entrantes, com frequência, podem aumentar o bem estar do consumidor. A ideia de que um potencial entrante pode limitar condutas abusivas de um agente econômico em posição dominante, explica SALOP, é central à análise de barreiras à entrada, da concorrência potencial e de poder de mercado. Assim, o teste seria deficiente para detectar condutas de exclusão potencialmente ilícitas. ${ }^{326}$

\footnotetext{
${ }^{326}$ SALOP, Steven C. Economic Analysis of Exclusionary Vertical Conduct: Where Chicago has Overshot the Mark. In: PITOFSKY, Robert (Ed.). How the Chicago School Overshot the Mark. The Effect of Conservative Economic Analysis of U.S. Antitrust, Oxford University Press, 2008, p. 153-154.
} 


\section{CAPÍtUlO IV - ABUSO DE POSIÇÃO DOMINANTE E ESTRATÉGIAS DE DISTRIBUIÇÃO}

\section{INTRODUÇÃO}

Fornecedores de bens e serviços adotam diversas técnicas e estratégias comerciais para escoar a sua produção, para facilitar a colocação de seus produtos e serviços no mercado e para aumentar suas vendas. Neste sentido, fornecedores adotam estratégias comerciais e de distribuição, que envolvem diversas decisões, tais como: decisões acerca das formas de introdução, comercialização, da apresentação e divulgação de seus produtos e serviços no mercado, do estabelecimento de preços dos produtos ou serviços, do estabelecimento de programas de incentivo à aquisição de produtos e serviços e de condições na relação entre fornecedores, distribuidores e revendedores.

Na busca de solucionar o problema do escoamento da produção, um fornecedor pode escolher diferentes caminhos: desempenhar internamente as funções de produção e distribuição; designar um terceiro para identificar consumidores; ou fornecer seus produtos a um distribuidor, cuja função é revender os produtos a terceiros, que, por sua vez, podem ou não ser os consumidores finais. ${ }^{327}$

Quando fornecedores optam por utilizar intermediários na distribuição de seus produtos (ao invés distribuir seus produtos diretamente), podem adotar estratégias de distribuição que envolvem relações verticais. Nos termos da classificação tradicionalmente utilizada pela análise antitruste, relações verticais são definidas como aquelas existentes entre agentes econômicos em diferentes etapas da cadeia produtiva. Uma relação vertical pode ser descrita como uma linha imaginária que percorre a extração de insumos ao longo das etapas de produção e de venda ao consumidor final. ${ }^{328}$

Nas relações entre fornecedores e distribuidores ou revendedores, uma série de acordos, cláusulas ou condições contratuais podem ser estabelecidas, que tendem a restringir a atuação de fornecedores ou distribuidores. Estas restrições são chamadas pela literatura antitruste de restrições verticais. Nessa linha, na definição de FORGIONI,

\footnotetext{
${ }^{327}$ WHISH, Richard. Competition Law. 5th Edition, LexisNexis Buttersworths, 2005, p. 583.

${ }^{328}$ FOX, Eleanor M.; SULLIVAN, Lawrence A. Cases and Materials on Antitrust. American Casebook Series, West Publishing Co., St. Paul, Minn., 1989, p. 522.
} 
restrições verticais são "estipulações contratuais geralmente inseridas nos acordos verticais que restringem a liberdade de atuação do distribuidor ou do fornecedor." ${ }^{329}$ Nos termos da definição europeia, ainda, restrições verticais são acordos ou práticas entre dois ou mais agentes econômicos que operam, para os fins do acordo, em níveis diferentes da cadeia de produção ou distribuição, relacionadas a condições conforme as quais as partes podem comprar, vender ou revender determinados produtos ou serviços. ${ }^{330}$

Como já dito, uma série de casos da jurisprudência internacional acerca de abuso de posição dominante envolve situações em que estratégias de distribuição adotadas por fornecedores que ocupam posição dominante foram questionadas em razão de seu potencial de exclusão. Há um grupo de situações, portanto, que se localiza na intersecção entre casos envolvendo ilícitos de abuso de posição dominante e casos que envolvem estratégias de distribuição com potencial de exclusão. Este grupo de situações é o que interessa ao nosso estudo.

De início, vale notar que as práticas de distribuição tendentes à exclusão de rivais geralmente envolvem as chamadas restrições verticais intermarcas. Como se sabe, a literatura antitruste tradicionalmente classifica as restrições verticais em duas categorias principais: as restrições verticais intramarcas e as restrições verticais intermarcas. As restrições verticais intramarcas são aquelas que afetam a concorrência entre fornecedores da mesma marca e as restrições verticais intermarcas ou entre marcas são aquelas que afetam a concorrência entre marcas de fornecedores concorrentes. Conforme aponta GAVIL, a análise econômica das restrições verticais intermarcas é mais complexa que a análise das restrições intramarcas e tem sido caracterizada por um intenso debate acadêmico. $^{331}$

\footnotetext{
${ }^{329}$ FORGIONI, Paula. A. Direito Concorrencial e Restrições Verticais. São Paulo: Editora Revista dos Tribunais, 2007, p. 25-26.

${ }^{330}$ No original, em português: "acordos ou práticas concertadas em que participam duas ou mais empresas cada uma delas operando, para efeitos do acordo, a um nível diferente da produção ou da cadeia de distribuição e que digam respeito às condições em que as partes podem adquirir, vender ou revender certos bens ou serviços". Artigo 2 (1) do REGULAMENTO (CE) N.o 2790/1999 DA COMISSÃO de 22 de Dezembro de 1999 relativo à aplicação do artigo 81 do Tratado CE a determinadas categorias de acordos verticais e práticas concertadas. Jornal Oficial das Comunidades Europeias, 29. 12. 1999.

${ }^{331}$ GAVIL, Andrew I. Exclusionary Distribution Strategies by Dominant Firms: Striking a Better Balance. In: Antitrust Law Journal, V. 72, 2004, p. 9.
} 
Esta categoria de restrições - restrições verticais intermarcas - tem sido gradualmente ampliada para incluir não somente as práticas de distribuição envolvendo restrições verticais "tradicionais", mas também outros tipos de estratégias de preços ou estratégias promocionais destinadas, de uma forma geral, a atingir incremento de vendas ou algum grau de exclusividade. ${ }^{332}$ Como exemplo dos tipos "menos" tradicionais de práticas de distribuição, podemos identificar os vários tipos de descontos (e.g. descontos de fidelidade, descontos em pacote (bundling), descontos ligados a metas de vendas), estratégias promocionais e estratégias de alocação de produtos em prateleiras, tais como a prática de administração por categorias (category management) e os pagamentos para colocação de produtos em prateleiras (slotting fees). ${ }^{333}$ Vale notar, ainda, que há situações que combinam práticas de distribuição tradicionais com as menos tradicionais. Observa-se, assim, que há uma ampla gama de práticas de distribuição que podem ser utilizadas de forma isolada ou em combinação por fornecedores que buscam definir como distribuir e colocar seus produtos/serviços no mercado.

A literatura antitruste estrangeira dos últimos anos tem se dedicado a buscar identificar a melhor forma de adequadamente analisar estes "novos" tipos de estratégias de distribuição. Entre outros aspectos, estas "novas estratégias" podem envolver restrições verticais que se assemelham às restrições verticais observadas em práticas de distribuição tradicionais, mas com elas não se identificam. Há, assim, um intenso debate acadêmico, principalmente na literatura norte-americana, sobre quais os padrões de análise devem ser utilizados com relação às formas menos tradicionais de distribuição.

Como se sabe, ainda, as práticas de distribuição que envolvem restrições verticais intermarcas podem ter justificativas econômicas e comerciais legítimas, podendo trazer diversos benefícios de eficiência. Muitas destas justificativas estão ligadas à teoria dos

\footnotetext{
${ }^{332}$ GAVIL, Andrew I. Exclusionary Distribution Strategies by Dominant Firms: Striking a Better Balance. In: Antitrust Law Journal, V. 72, 2004, p. 9

${ }^{333}$ GAVIL comenta que a avaliação das restrições verticais intermarcas ganha maior complexidade com os descontos e outros regimes de incentivos: “...(a) factor that complicates the evaluation of interbrand restraints today is a relatively contemporary development. Although in the past these kinds of arrangements were typified by tying, exclusive dealing, outputs and requirements agreements, today the category has been broadened to include various kinds of promotional strategies that are designed to secure some degree of exclusivity, such as market share and loyalty discounts, and product bundling, which also may be accompanied by a discount." GAVIL, Andrew I. Exclusionary Distribution Strategies by Dominant Firms: Striking a Better Balance. In: Antitrust Law Journal, V. 72, 2004, p. 10.
} 
custos de transação, que pode ser considerada como uma evolução da chamada teoria da firma. $^{334}$

No âmbito antitruste, a teoria de custos de transação teve enorme impacto na compreensão dos fenômenos de integração vertical e de restrições verticais. Na perspectiva dos custos de transação, a integração vertical e as restrições verticais são opções organizacionais, escolhidas com o objetivo de aumentar os benefícios de eficiência para a firma. ${ }^{335}$ Ao decidir se deve produzir um item internamente, por exemplo, uma determinada firma deve comparar os custos desta produção com os custos de adquirir o produto no mercado; os custos de adquirir o produto no mercado, por sua vez, devem levar em consideração, entre outros, os custos de identificar parceiros comerciais e preços, negociar os contratos, e a possibilidade de que um parceiro comercial possa adotar algum tipo de comportamento oportunista. ${ }^{336} \mathrm{~A}$ partir da análise destes custos, uma determinada firma pode escolher produzir internamente o item, procurar o item no mercado ou, como é frequente, escolher formas de "integração parcial" por contrato, obtendo grande parte dos benefícios da integração sem parte de seus custos. ${ }^{337}$ Nessa linha, a chave para a compreensão das restrições verticais é o seu potencial para economizar custos de transação.

A principal contribuição da teoria dos custos de transação ao estudo das restrições verticais, portanto, foi identificar benefícios de eficiência que poderiam ser trazidos por elas. Em linhas gerais, estes benefícios estariam ligados à ideia de que restrições verticais são

\footnotetext{
334 Como é sabido, o marco fundamental da teoria da firma e da teoria dos custos de transação é identificado na publicação do artigo de COASE, The Nature of the Firm, em 1937. (COASE, Ronald H. The Nature of the Firm. In: Economica, v. 4, 1937, p. 386-405). Neste artigo, ao buscar explicar a gênese da firma, COASE concluiu que a opção por internalizar diferentes etapas do processo de produção dentro da firma se explica pelos custos de se recorrer ao mercado em um mundo de informação imperfeita (custos de transação). Conforme COASE: "The main reason why it is profitable to establish a firm would seem to be that there is a cost of using the price mechanism". WILLIAMSON desenvolveu o insight original de COASE e popularizou a chamada teoria dos custos de transação. WILLIAMSON procurou operacionalizar a ideia de custos de transação, ao atribuir dimensões às transações, utilizando elementos objetivos e observáveis. O nível dos custos de transação, por sua vez, definiria a forma organizacional eficiente para governar cada transação. (WILLIAMSON, Oliver E. Markets and Hierarchies, New York: The Free Press, 1975, p. 26-37).

${ }^{335}$ GRIMES, Warren S. Brand Marketing, Intrabrand Competition, and the Multibrand Retailer: The Antitrust Law of Vertical Restraints. In: Antitrust Law Journal, v. 64, 1995, p. 88.

${ }^{336}$ Para uma descrição dos principais custos de transação identificados pela doutrina especializada, ver FORGIONI, Paula. Direito Concorrencial e Restrições Verticais. Editora Revista dos Tribunais, 2007, p. 32 e seguintes.

${ }^{337}$ MEESE, Alan J. Price Theory and Vertical Restraints. In: UCLA Law Review, v. 45, p. 168.
} 
formas de reduzir ou economizar custos de transação. ${ }^{338}$ Em particular, com relação às restrições verticais intermarcas, a teoria dos custos de transação trouxe explicações importantes, tais como a proteção ao investimento de fornecedores em distribuidores e a proteção contra condutas oportunistas.

No contexto da distribuição, a teoria dos custos de transação oferece explicações quanto às decisões de fornecedores acerca de como distribuir e colocar seus produtos ou serviços no mercado. Quando fornecedores optam por utilizar intermediários na distribuição de seus produtos (ao invés distribuir seus produtos diretamente), podem utilizar determinadas disposições contratuais em diferentes estágios da cadeia de produção/distribuição que restrinjam a sua própria liberdade e/ou a liberdade de seus intermediários, com o objetivo de alinhar incentivos entre as partes e reduzir custos de transação. Em algumas circunstâncias, é mais eficiente realizar esta tarefa internamente, ou seja, é mais eficiente que o próprio fornecedor do produto realize a tarefa da distribuição; em outras circunstâncias, pode ser mais eficiente que o fornecedor utilize intermediários.

No presente capítulo, examinaremos as práticas de distribuição tendentes à exclusão mais usualmente utilizada por distribuidores. No próximo item (item 2), trataremos dos tipos de práticas mais tradicionais, quais sejam: as práticas de preços predatórios, a exclusividade, a recusa unilateral de contratar e a venda casada (ou acordos de vinculação). A análise destas práticas será feita de forma bastante resumida e seu o objetivo, no âmbito deste trabalho, é situá-las na discussão sobre exclusão empreendida até aqui. Em comum, tais práticas têm o potencial de excluir rivais do agente econômico em posição dominante que as adota.

Em seguida, no item 3 deste capítulo, examinaremos algumas estratégias de distribuição "menos tradicionais", porém usuais, que também podem ter efeitos de exclusão. Focaremos, principalmente, nas práticas de descontos e nos arranjos relacionados a colocação de produtos em prateleiras.

\footnotetext{
${ }^{338}$ MEESE explica que enquanto a Escola de Chicago pouco contribuiu quanto à demonstração dos efeitos de eficiência que seus teóricos acreditavam existir, a teoria dos custos de transação trouxe explicações de eficiência que contribuíram para a análise das restrições verticais. MEESE, Alan J. Exclusive Dealing, The Theory of the Firm, and Raising Rival's Costs: Toward a New Synthesis. In: The Antitrust Bulletin, v. 50, n. 3, Fall 2005, p 394.
} 


\section{ESTRATÉGIAS DE DISTRIBUIÇÃO TRADICIONAIS}

\subsection{Preços predatórios}

No Capítulo III, tratamos das principais discussões econômicas relacionadas à prática de preços predatórios. Em linhas gerais, a prática de preços predatórios ocorre quando um agente econômico dominante vende seus produtos abaixo de alguma medida de custo, suportando perdas por um determinado período de tempo, com o objetivo ou potencial efeito de excluir ou dificultar o desenvolvimento de concorrentes, para, ao final, recuperar seus lucros e poder cobrar preços acima do nível competitivo.

Conforme explicação de WHISH, a ideia de preços predatórios é bastante simples. Um agente econômico em posição dominante, ao enfrentar concorrência de um rival já estabelecido ou um novo entrante, decide reduzir seus preços a um nível que possa lhe causar perdas temporariamente. Quando o rival existente é "disciplinado" pela redução de preços do agente dominante e o novo entrante possivelmente desiste de entrar no mercado, o agente em posição dominante pode aumentar seus preços novamente, a um nível supracompetitivo, auferindo maiores lucros, pelo menos até uma nova "onda de ataques" de concorrentes ou potenciais entrantes. WHISH acrescenta, ainda, que, quando um agente em posição dominante tem uma "reputação" de atuar de forma predatória, este aspecto, por si só, pode desencorajar a entrada de novos concorrentes; neste sentido, não somente os preços predatórios em si seriam um problema de ordem concorrencial, mas também a reputação do predador poderia configurar uma espécie de barreira à entrada. ${ }^{339}$

Nos termos do Documento Europeu sobre Abusos de Exclusão, um agente dominante adota um comportamento predatório, quando deliberadamente suporta perdas ou prescinde de ganhos a curto prazo, "por forma a excluir ou poder vir a excluir um ou mais concorrentes, existentes ou potenciais, com o objectivo de reforçar ou manter o seu poder de mercado e prejudicando desta forma o consumidor" (item 63).

Um dos principais dilemas das discussões envolvendo preços predatórios refere-se ao fato de que preços baixos são vistos como parte da essência da concorrência. Em

\footnotetext{
${ }^{339}$ WHISH, Richard. Competition Law. 6th Edition, LexisNexis Buttersworths, 2008, p. 730. Quanto à questão da "reputação de predador" de um agente econômico em posição dominante, referimo-nos às considerações feitas no Capítulo III, lembrando que este seria um dos argumentos pós-Chicago acerca da plausibilidade das estratégias de preços predatórios.
} 
princípio, a disciplina da concorrência deve permitir que, mesmo agentes econômicos em posição dominante, possam adotar condutas agressivas de preço; caso contrário, as normas concorrenciais podem justamente inibir comportamentos que deveriam incentivar. Neste sentido, vale referir a decisão da Suprema Corte norte-americana no já mencionado caso Matsushita, de 1986, que afirmou que inferências equivocadas acerca de casos de preços predatórios podem ter o efeito de desencorajar condutas que as normas antitruste seriam designadas a proteger ou incentivar. ${ }^{340}$

Conforme apontado no capítulo anterior, nos Estados Unidos, casos envolvendo práticas convencionais de preços predatórios tornaram-se cada vez mais difíceis de serem decididos contra os supostos predadores. Outros tipos de casos envolvendo práticas de exclusão ligadas a preço, no entanto, tais como discussões sobre descontos e outros arranjos de preço, tornaram-se mais comuns no cenário norte-americano, gerando teorias alternativas à teoria convencional de preços predatórios. ${ }^{341}$

No Brasil, a conduta de preços predatórios é listada de entre os exemplos de comportamentos que podem configurar infrações à ordem econômica no item XVIII do artigo 21 da Lei 8.884/94, que trata da "venda injustificada de mercadoria abaixo do preço de custo." Este item foi praticamente reproduzido no item XV do parágrafo $3^{\circ}$ do artigo 36 da Lei 12.529/2011, cuja redação passou a ser a seguinte: "vender mercadoria ou prestar serviços injustificadamente abaixo do preço de custo”. O inciso, portanto, foi modificado para incluir a prestação de serviços injustificadamente abaixo do preço de custo e não somente a venda injustificada de mercadoria abaixo do preço de custo.

De acordo com o Anexo I da Resolução 20/1999, preços predatórios envolvem a "prática deliberada de preços abaixo do custo variável médio, visando eliminar concorrentes para, em momento posterior, poder praticar preços e lucros mais próximos do nível monopolista." O Anexo I, ainda, explica que "o exame desta prática requer análise detalhada das condições efetivas de custos e do comportamento dos preços ao longo do tempo, para afastar a hipótese de práticas sazonais normais ou de outras

\footnotetext{
${ }^{340}$ No original: "...mistaken inferences in cases such as this chill the very conduct that antitrust laws are designed to protect." Matsushita v. Zenith Radio 475 US 574 (1986).

${ }^{341}$ HOVENKAMP, Herbert. The Law of Exclusionary Pricing. In: Competition Policy International, v. 2, n. 1. Spring, 2006, p. 21.
} 
políticas comerciais da empresa, além da análise de comportamento estratégico, avaliando-se as condições objetivas de ganhos potencialmente extraordinários posteriores suficientemente elevados e capazes de compensar as perdas decorrentes das vendas abaixo do custo."

Vale notar, ainda, que a Secretaria de Acompanhamento Econômico editou a Portaria 70, de 12 de dezembro de $2002^{342}$, com o objetivo oferecer um Guia para Análise Econômica da Prática de Preços Predatórios. Em linhas gerais, o referido guia considera que a prática pode ocorrer quando "uma firma dominante impõe preços abaixo do custo médio de produção, durante um período de tempo suficientemente longo, tendo por intenção expulsar alguns rivais ou deter a entrada de outros para que, no momento seguinte, possa elevar seus preços, significativamente, na tentativa de recuperar suas perdas iniciais em um mercado menos competitivo."

Um caso da jurisprudência nacional acerca de possível prática predatória refere-se à representação feita em 2004, pelo Ministério da Defesa, a partir de estudo elaborado pelo Departamento de Aviação Civil (DAC), em razão de suposta prática de preços predatórios pela empresa Gol Linhas Aéreas S.A. (Gol). ${ }^{343}$ A investigação envolvia a análise da validade, à luz da Lei 8.884/94, da promoção “Viagem por R $\$ 50,00 ”$, operada pela Gol para diversos trechos, durante um determinado período de tempo. O Ministério da Defesa argumentou que a prática adotada pela Gol era predatória, porque a tarifa promocional estaria, de alguma forma, abaixo dos custos médios total e variável na maioria dos trechos em que a promoção vigoraria e que, em geral, a tarifa estimada de cada trecho englobado pela promoção também seria inferior aos custos médios totais variáveis do trecho correspondente.

Em seu voto, o Conselheiro Relator Ricardo Villas Bôas Cueva acolheu o entendimento esposado no parecer proferido pela SEAE, e considerou que a conduta da Gol não teria configurado prática de preços predatórios. Em linhas gerais, o relator considerou que: a tarifa da Gol de $\mathrm{R} \$ 50,00$ seria, de fato, uma promoção, restrita a um período de

\footnotetext{
${ }^{342}$ SECRETARIA DE ACOMPANHAMENTO ECONÔMICO, Portaria 70, de 12 de dezembro de 2002, publicada no Diário Oficial da União n. 241m de 13/12/2002, Seção 1, p. 138 a 139.

${ }^{343}$ Averiguação Preliminar no 08001.006298/2004-3. Representante: Ministério da Defesa. Representada: Gol Linhas Aéreas S/A. Relator: Ricardo Villas Boas Cueva. Decisão proferida em 01 de fevereiro de 2006.
} 
tempo e a um número limitado de assentos; a promoção teria justificativas econômicas e comerciais (teria vigorado em um período de baixa estação); e que a promoção não poderia ser considerada como uma tentativa de eliminar concorrentes do mercado.

O relator considerou, ainda, que o DAC, em sua representação, teria partido de pressupostos equivocados ao considerar a promoção da Gol como prática predatória, entre outros aspectos, porque teria calculado de forma errônea o parâmetro de custo a ser usado na comparação com o preço. O DAC teria, ainda, ignorado a análise da estrutura de mercado, de poder de mercado ou da posição dominante da Gol (que demonstrou-se inexistente) ou, mesmo, de barreiras à entrada, aspectos essenciais à verificação da possibilidade de o agente supostamente predador excluir rivais e recuperar possíveis perdas em período posterior à "predação". Por fim, o relator conclui que "a prática de promoções, bem ao contrário do que faz acreditar a representação, tem o condão de aumentar o bemestar dos consumidores e das próprias companhias; permite que mais consumidores sejam capazes de viajar e que as companhias aéreas implementem classes tarifárias que tornem o seu método de preços mais eficientes."344

Finalmente, um exame das decisões do CADE proferidas nos últimos 5 (cinco) anos demonstra que, não obstante diversas investigações por preços predatórios terem sido iniciadas, as decisões proferidas durante este período foram todas no sentido de inexistência de preços predatórios. Muitas destas decisões determinaram o arquivamento das investigações em razão de ausência de posição dominante do agente supostamente predador e do fato de a estrutura de mercado ser incompatível com a prática de preços predatórios.

\subsection{Exclusividade}

Como já tivemos a oportunidade de tratar em outro trabalho, a exclusividade é fenômeno que se verifica com frequência no âmbito da distribuição de bens e serviços. ${ }^{345}$

Em linhas gerais, a exclusividade embute o compromisso por parte do comprador (ou distribuidor) de adquirir (e/ou comercializar) produtos ou serviços de apenas um

\footnotetext{
${ }^{344}$ Para uma análise crítica do caso, ver RAGAZZO, Carlos Emmanuel Joppert; SILVA, Rutelly Marques. "Viaje por R\$50,00": Promoção ou Preço Predatório?, disponível em http://works.bepress.com/carlos ragazzo/10, acesso em novembro de 2011.

345 CORRÊA, Mariana Villela. Exclusividade e Direito da Concorrência. Dissertação de Mestrado apresentada ao Departamento de Direito Comercial, Universidade de São Paulo, Faculdade de Direito, São Paulo, 2008.
} 
fornecedor. Nestes casos, o comprador/distribuidor tem a sua liberdade de contratar limitada, uma vez que se vê impedido de adquirir ou comercializar produtos de fornecedores concorrentes. Da mesma forma, os fornecedores concorrentes deixam de ter acesso ao comprador/distribuidor vinculado pela exclusividade. Quando um fornecedor em posição dominante firma acordos de exclusividade com um número razoável de distribuidores, pode causar o efeito de impedir o acesso de outros fornecedores a canais de distribuição relevantes. ${ }^{346}$

Os potenciais efeitos de exclusão deste tipo de prática são claros. Quando um ou mais compradores/distribuidores se obrigam a somente adquirir ou comercializar produtos de um determinado fornecedor, o efeito desta obrigação pode ser o de obstruir ou fechar o acesso de outros fornecedores ao mercado dos compradores/distribuidores vinculados. Como consequência, a prática pode potencialmente excluir concorrentes rivais ou aumentar seus custos, principalmente os custos relacionados à distribuição de seus produtos/serviços.

O Documento Europeu sobre Abusos de Exclusão inclui entre as formas específicas de abuso de exclusão, os chamados "acordos exclusivos". Nos termos do referido documento, "uma empresa dominante pode tentar excluir empresas concorrentes impedindo-as de vender a clientes através da utilização de acordos exclusivos, de descontos ou de obrigação de compra, práticas denominadas em conjunto como acordos exclusivos" (item 32).

Conforme já afirmamos ${ }^{347}$, a exclusividade pode ser estabelecida em um acordo por meio do qual um comprador diretamente se compromete perante um determinado fornecedor a não adquirir e/ou comercializar produtos de fornecedores concorrentes; em outros casos, no entanto, a exclusividade pode resultar de outros arranjos comerciais que tenham resultados semelhantes, situações às quais chamamos de exclusividade de fato. ${ }^{348}$ Alguns autores também utilizam a terminologia de exclusividade parcial para designar as

\footnotetext{
${ }^{346}$ Nos Estados Unidos, estas situações são usualmente denominadas como exclusive dealing (exclusividade de comercialização) ou exclusive purchase (exclusividade de compra). Na Europa, a obrigação de um comprador em não adquirir produtos de outros fornecedores é referida como uma obrigação de nãoconcorrência (non-competition), single branding agreements (acordos de uma só marca) ou, simplesmente, "acordos exclusivos".

347 CORRÊA, Mariana Villela. Exclusividade e Direito da Concorrência. Dissertação de Mestrado apresentada ao Departamento de Direito Comercial, Universidade de São Paulo, Faculdade de Direito, São Paulo, 2008.

${ }^{348}$ Conforme WHISH, Richard. Competition Law. 5th Edition, LexisNexis Buttersworths, 2005, p. 657.
} 
situações que chamamos de exclusividade de fato. ${ }^{349}$ Vale notar, contudo, que tanto a exclusividade diretamente pactuada - que chamamos de exclusividade clássica ou tradicional - quanto a exclusividade de fato pode ser absoluta (i.e., envolver a totalidade dos produtos/serviços adquiridos ou comercializados pelo comprador), ou parcial (i.e., envolver parte dos produtos/serviços adquiridos ou comercializados pelo comprador).

A exclusividade de fato, portanto, ocorre quando a exclusividade de compra ou comercialização não é diretamente pactuada, mas se deduz das circunstâncias que envolvem as relações comerciais entre as partes ou quando é consequência de outros arranjos contratuais ou práticas comerciais que, indiretamente, resultam em uma situação de exclusividade. Nestes casos, o compromisso assumido pelo comprador não é o de adquirir ou comercializar produtos ou serviços somente de um fornecedor; outras obrigações assumidas pelo comprador (e.g. de somente acondicionar ou estocar produtos de um determinado fornecedor), no entanto, indiretamente resultam em obrigações de exclusividade de compra ou comercialização.

A exclusividade pode ter diversas justificativas comerciais e econômicas, amplamente aceitas na literatura antitruste, especialmente no que se refere às justificativas ligadas à teoria dos custos de transação. Entre elas, destacamos a prevenção de condutas oportunistas de fornecedores concorrentes (prevenção do problema do free rider), proteção a investimentos dos fornecedores em seus distribuidores, proteção a investimentos dos fornecedores com relação ao problema do hold up ("extorsão pós contratual”) 350 , entre outros. ${ }^{351}$ A exclusividade pode ser - e, muitas vezes, é - um importante e eficiente instrumento adotado por fornecedores que optam por utilizar intermediários na tarefa da distribuição de seus produtos/serviços.

Conforme já mencionado, a não inclusão da exclusividade entre os comportamentos listados no parágrafo $3^{\circ}$ do artigo 36 da Lei 12.529/2011 não significa que a exclusividade

\footnotetext{
349 JACOBSON, Jonathan M. Exclusive Dealing, "Foreclosure", and Consumer Harm. In: Antitrust Law Journal, v. 70, 2002, p. 341.

${ }^{350}$ O termo "extorsão pós-contratual" é utilizado por FORGIONI com referência ao problema do hold-up. FORGIONI, Paula A. Direito Concorrencial e Restrições Verticais. São Paulo: Editora Revista dos Tribunais, 2007, p. 151-152.

${ }^{351}$ A este respeito, ver nosso Exclusividade e Direito da Concorrência, p. 164-189. CORRÊA, Mariana Villela. Exclusividade e Direito da Concorrência. Dissertação de Mestrado apresentada ao Departamento de Direito Comercial, Universidade de São Paulo, Faculdade de Direito, São Paulo, 2008.
} 
deixaria de ser considerada como uma infração à ordem econômica. O rol do referido parágrafo é meramente exemplificativo e não exaure todas as situações que, caso venham a incidir em quaisquer dos incisos do caput do artigo 36, podem configurar infração à ordem econômica. Além disto, outros incisos constantes do rol exemplificativo do parágrafo $3^{\circ}$ podem servir de fundamento para que a exclusividade venha a ser considerada como um potencial ilícito antitruste. $^{352}$

Um exame da jurisprudência administrativa brasileira demonstra que as autoridades de defesa da concorrência brasileiras já tiveram oportunidade de examinar vários casos que tratavam da exclusividade em suas várias formas de manifestação. Quanto à exclusividade clássica, podemos referir o caso de exclusividade de comercialização no mercado de cigarros $^{353}$ e os casos envolvendo cláusulas de exclusividade e cláusulas de raio entre shopping centers e lojistas. ${ }^{354}$ Ao tempo de conclusão deste trabalho, as autoridades examinavam, ainda, um processo administrativo que envolvia situação de exclusividade de fato, qual seja, o caso de exclusividade de merchandising no mercado de cigarros. ${ }^{355}$ Ainda, em 2009, o CADE decidiu processo administrativo que investigava o programa de relacionamento estabelecido no mercado de cervejas, que foi considerado como envolvendo aspectos de exclusividade e que será tratado adiante. ${ }^{356}$

Vale notar, ainda, que decisões judiciais já trataram da exclusividade sob a perspectiva da disciplina da concorrência, ainda que de forma incidental. O exame das decisões judiciais demonstra, contudo, que os tribunais brasileiros, quando examinaram a exclusividade do ponto de vista concorrencial, não aprofundaram as discussões acerca da

\footnotetext{
${ }^{352}$ Entre estes, podemos citar o inciso III ("limitar ou impedir o acesso de novas empresas ao mercado"), inciso IV ("criar dificuldades à constituição, ao funcionamento ou ao desenvolvimento de empresa concorrente ou de fornecedor, adquirente ou financiador de bens ou serviços") e o inciso V ("impedir o acesso de concorrente às fontes de insumo, matérias-primas, equipamentos ou tecnologia, bem como aos canais de distribuição").

${ }^{353}$ Processo Administrativo no 08012.003303/98-25. Representante: Philip Morris Brasil S.A. Representada: Souza Cruz S.A..

${ }^{354}$ Processo Administrativo no 08012.009991/98-82. Representante: Participações Morro Vermelho Ltda.. Representada: Condomínio Shopping Center Iguatemi; e Processo Administrativo no 08012.002841/2001-13. Representante: Condomínio Shopping D. Representado: Center Norte S.A.

${ }^{355}$ Processo Administrativo $\mathrm{n}^{\circ}$ 08012.003921/2005-10. Representante: Conselho Administrativo de Defesa Econômica; Representadas: Souza Cruz S/A e Philip Morris Brasil Indústria e Comércio Ltda.

${ }^{356}$ Processo Administrativo no. 08012.003805/2004-10. Representante: Primo Schincariol Indústria de Cervejas e Refrigerantes S/A; Representada: Companhia de Bebidas das Américas - AMBEV. Decisão do CADE proferida em 22 de julho de 2009. Conselheiro Relator: Fernando de Magalhães Furlan.
} 
forma e dos critérios de aplicação da Lei 8.884/94. Isto se explica, em alguns casos, devido ao fato de que as partes não trouxeram tais discussões à análise dos tribunais e, em outros casos, em razão de que outros aspectos eram mais centrais ao objeto da lide.

Assim, o exame dos aspectos concorrenciais da exclusividade nas decisões judiciais tem sido, na maioria das vezes, meramente tangencial às principais discussões de cada caso. Os argumentos acerca das cláusulas de exclusividade, nos termos da Lei 8.884/94 foram feitos quase sempre incidentalmente, entre outros vários argumentos relacionados à validade de cláusulas de exclusividade sob outras perspectivas. Em geral, os tribunais consideram que, em princípio, a exclusividade não viola a ordem econômica; no entanto, há poucas referências às circunstâncias em que ela não seria lícita do ponto de vista da disciplina da concorrência. ${ }^{357}$

\subsection{Recusa unilateral de contratar}

Conforme explica SAMPAIO, a recusa unilateral de contratar é tema controverso da disciplina da concorrência, não obstante mais de um século de estudos doutrinários a respeito. $^{358}$

Em princípio, os agentes econômicos têm liberdade de contratar e escolher seus parceiros comerciais. Mesmo em situações em que a disciplina da concorrência possa conceber a negativa unilateral de contratação como um potencial ilícito concorrencial, o agente econômico dominante que se recusa a negociar pode ter justificativas legítimas para negar a contratação (e.g., histórico de inadimplemento do potencial contratante). Ainda, a determinação de que um agente econômico, mesmo em posição dominante, venha a ser obrigado a contratar com um ou mais parceiros comerciais pode não ser medida compatível com ideias relacionadas à prevenção de comportamentos oportunistas e à proteção de investimentos feitos pelo agente econômico dominante.

\footnotetext{
357 A este respeito, referimo-nos à análise feita em nosso Exclusividade e Direito da Concorrência. Dissertação de Mestrado apresentada ao Departamento de Direito Comercial, Universidade de São Paulo, Faculdade de Direito, São Paulo, 2008.

${ }^{358}$ Conforme SAMPAIO: "Em que pese mais de um século de estudos doutrinários sobre o tema, a disciplina jurídica das recusas de contratar ainda se mostra questão altamente controvertida, como de resto apresentam-se, de forma geral, as diversas espécies de restrições verticais." SAMPAIO, Patrícia Regina Pinheiro. Direito da Concorrência e Obrigações de Contratar, Rio de Janeiro, Editora Elsevier, 2009, p. 113. No mesmo sentido, ver WHISH, Richard. Competition Law. 6th Edition, LexisNexis Buttersworths, 2008 , p. 687.
} 
No Brasil, a conduta de recusa de contratar é listada de entre os exemplos de comportamentos que podem configurar infrações à ordem econômica, nos seguintes itens do artigo 21 da Lei 8.884/94: inciso XIII ("recusar a venda de bens ou a prestação de serviços, dentro das condições de pagamento normais aos usos e costumes comerciais") e inciso XIV (“dificultar ou romper a continuidade ou o desenvolvimento de relações comerciais de prazo indeterminado em razão de recusa da outra parte em submeter-se a cláusulas e condições comerciais injustificáveis ou anticoncorrenciais”). Estes itens foram reproduzidos nos itens XI e XII do parágrafo $3^{\circ}$ do artigo 36 da Lei 12.529/2011. ${ }^{359}$

A recusa de contratar pode ser considerada como correlata à ideia de exclusividade. Conforme afirma SAMPAIO, "na prática, contratar a exclusividade de fornecimento ou distribuição de um determinado bem implica, na outra face, recusar-se a contratar com qualquer terceiro não participante do contrato". ${ }^{360}$ Em sentido semelhante, GONÇALVES explica que a existência de contratos de exclusividade com terceiros é justificativa recorrente para a recusa de contratar. ${ }^{361}$

GONÇALVES explica, ainda, que as recusas de contratar podem ser diretas ou indiretas. As recusas de contratar diretas são aquelas por meio das quais um agente econômico se recusa a negociar com outro, podendo ou não apresentar justificativa para tanto. Nas recusas de contratar indiretas, "não há negativa pura e simples, mas as condições com base nas quais a pessoa física ou jurídica admite negociar são consideradas inaceitáveis pela contraparte, seja em razão de preços excessivos, seja em razão de outras condições gravosas. ${ }^{362}$ Neste sentido, vale mencionar a referência feita no Documento Europeu sobre Abusos de Exclusão, que afirma: "não é necessário a existência

\footnotetext{
${ }^{359}$ Conforme SAMPAIO, outros itens do artigo 21 da Lei 8.884/94 têm pertinência com o tema da recusa de negociação, tais como os incisos IV (limitar ou impedir o acesso de novos agentes ao mercado), inciso V (criar dificuldades à constituição, ao funcionamento ou ao desenvolvimento de empresa concorrente ou de fornecedor, adquirente ou financiador de bens ou serviços), inciso VI (impedir acesso de concorrentes às fontes de insumo, matérias-primas, equipamentos ou tecnologia, bem como aos canais de distribuição), inciso VII (exigir ou conceder exclusividade para divulgação de publicidade nos meios de comunicação de massa). SAMPAIO, Patrícia Regina Pinheiro. Direito da Concorrência e Obrigações de Contratar, Rio de Janeiro, Editora Elsevier, 2009, p. 120-121.

${ }^{360}$ SAMPAIO, Patrícia Regina Pinheiro. Direito da Concorrência e Obrigações de Contratar, Rio de Janeiro, Editora Elsevier, 2009, p. 224.

${ }^{361}$ GONÇALVES. Priscila Brolio. A obrigatoriedade de contratar no direito antitruste. Editora Singular, 2010, p. 101.

${ }^{362}$ GONÇALVES. Priscila Brolio. A obrigatoriedade de contratar no direito antitruste. Editora Singular, 2010, p. 99.
} 
de uma recusa efectiva por parte da empresa dominante, sendo suficiente a existência de uma "recusa implícita"” (item 79).

O documento europeu, ainda, ao tratar da recusa de contratar (recusa de fornecimento), afirma que "a Comissão parte do princípio de que cada empresa, dominante ou não, deve ter o direito a escolher os seus parceiros comerciais e dispor livremente dos seus bens" (item 75), reconhecendo, portanto, como regra, o princípio da liberdade de contratar.

O documento, contudo, identifica circunstâncias em que a recusa de fornecimento por parte de um agente econômico em posição dominante pode configurar um abuso de exclusão. Entre outros aspectos, o documento afirma que “... a recusa de fornecimento pela empresa dominante pode eliminar, imediatamente ou a prazo, a concorrência efectiva no mercado a jusante." Ainda, o documento afirma que "a probabilidade de a concorrência efectiva ser eliminada é, em geral, tanto maior quanto maior for a quota de mercado da empresa dominante no mercado a jusante; quanto menor for a capacidade de pressão da empresa dominante em relação aos concorrentes no mercado a jusante; quanto maior for a proporção de concorrentes afectados no mercado a jusante e quanto maior for a probabilidade de a procura que poderia ser satisfeita pelos concorrentes excluídos, reverter em proveito da empresa dominante" (item 85 ).

WHISH observa que algumas objeções podem ser trazidas com relação à determinação, por uma autoridade antitruste (ou por uma decisão judicial), de que um agente econômico, mesmo dominante, seja obrigado a contratar com determinado parceiro comercial. ${ }^{363}$ Entre estas objeções, WHISH menciona o fato de que forçar um determinado agente econômico a fornecer determinado produto pode não conduzir a um efeito de bem estar econômico, uma vez que outros agentes econômicos podem pegar carona em investimentos feitos pelo agente dominante naquele determinado produto (problema do free rider). Em outras palavras, a determinação de obrigação de contratar pode criar uma espécie de falta de incentivo para que o agente dominante invista em determinados produtos ou em inovações tecnológicas, em razão da ameaça de que outros agentes econômicos (concorrentes) possam usufruir destes investimentos.

${ }^{363}$ WHISH, Richard. Competition Law. 6th Edition, LexisNexis Buttersworths, 2008, p. 688. 
Em sentido semelhante, afirma o Documento Europeu sobre Abusos de Exclusão: "a existência desta obrigação (de fornecimento por parte da empresa dominante), mesmo contra uma remuneração justa, poderá dissuadir a empresa de investir e de inovar e, por conseguinte, poderá prejudicar os consumidores". O documento prossegue nessa linha e afirma: "O conhecimento de que poderá existir uma obrigação de fornecimento contra a sua vontade pode conduzir as empresas dominantes - ou empresas que prevêem tornar-se dominantes - a não investirem ou investirem menos na actividade em questão. Os concorrentes poderão sentir-se igualmente tentados a aproveitar os investimentos feitos pela empresa dominante em vez de serem eles os investidores. A longo prazo, nenhuma destas consequências seria benéfica para os consumidores" (item 75).

As autoridades de defesa da concorrência brasileiras tiveram a oportunidade de examinar diversos casos em que recusas unilaterais de contratar foram questionadas, sob a alegação de tratar-se de um ilícito antitruste. Ao analisar a jurisprudência administrativa brasileira, SAMPAIO observa que, em regra, o CADE considera lícita a recusa de contratar, com base no princípio da livre iniciativa, desde que a prática não seja acompanhada de outras práticas excludentes. A autora observa, ainda, que o CADE tem demonstrado preocupação em diferenciar questões meramente privadas daquelas que envolvem a potencialidade de danos à concorrência. Além disto, SAMPAIO também conclui que, em diversos casos, as autoridades de defesa da concorrência buscaram identificar, na análise da licitude da conduta, se a recusa de contratar questionada estaria justificada por motivos comercialmente legítimos. ${ }^{364}$

Com efeito, a recusa unilateral de contratar pode ter justificativas comerciais e econômicas legítimas. SAMPAIO sumariza estas possíveis justificativas comerciais e econômicas, conforme a seguir: exigência de uma quantidade mínima de vendas capaz de tornar o negócio lucrativo, passado de inadimplemento do adquirente que deseja seguir contratando a prazo, necessidade de controlar a imagem dos produtos, proteção contra condutas oportunistas, entre outras. ${ }^{365}$

\footnotetext{
${ }^{364}$ SAMPAIO, Patrícia Regina Pinheiro. Direito da Concorrência e Obrigações de Contratar, Rio de Janeiro, Editora Elsevier, 2009, p. 136 e seguintes.

${ }^{365}$ SAMPAIO, Patrícia Regina Pinheiro. Direito da Concorrência e Obrigações de Contratar, Rio de Janeiro, Editora Elsevier, 2009, p. 145.
} 
GONÇALVES faz uma análise de decisões judiciais proferidas por tribunais brasileiros acerca da recusa unilateral de contratar, relativas a demandas relacionadas à recusa de contratar e à ruptura de contratos celebrados entre agentes econômicos por prazo indeterminado. ${ }^{366}$ Além de processos iniciados por agentes econômicos privados, GONÇALVES também identificou alguns casos iniciados pelo Ministério Público, por meio de inquéritos civis públicos e ações coletivas. A autora observa que, nos casos iniciados pelo Ministério Público, o fundamento das demandas era primordialmente consumerista; alguns argumentos de natureza concorrencial, no entanto, também teriam sido trazidos, ainda que de forma marginal. Conforme relato da autora, em alguns dos casos analisados, foram proferidas decisões que liminarmente determinaram a obrigação de contratação por parte dos agentes econômicos acusadas do ilícito de recusa de contratar. GONÇALVES, no entanto, reconhece que, no âmbito judicial, as discussões acerca da recusa de contratar ainda são incipientes.

\subsection{Vendas casadas ou acordos de vinculação (tying)}

Tipicamente, um acordo de venda casada pode ser descrito como um acordo por meio do qual um fornecedor condiciona a venda de um determinado produto ao compromisso por parte do comprador de que ele também irá adquirir um segundo produto, do mesmo fornecedor ou de um terceiro designado por este fornecedor. ${ }^{367}$ FORGIONI explica que a venda casada ocorre nas hipóteses em que "um sujeito subordina a venda de um bem (produto principal, produto subordinante ou tying product) à aquisição de outro, ou à utilização de um serviço (produto ou serviço vinculado, subordinado ou tied product)". 368

No exemplo clássico utilizado por GELLHORN, KOVACIC e CALKINS, um fornecedor de fotocopiadoras pode requerer que os compradores de suas máquinas adquiram toner deste mesmo fornecedor; nos termos de um acordo de venda casada, o

\footnotetext{
${ }^{366}$ GONÇALVES. Priscila Brolio. A obrigatoriedade de contratar no direito antitruste. Editora Singular, 2010, p. 205 e seguintes.

${ }^{367}$ Conforme VAN BAEL e BELLIS: "Strictly speaking the term "tying" refers to a situation where a supplier makes the purchase o fone product (the "tying product"), conditional upon the buyer also purchasing another distinct product (the "tied product"), either from the supplier of the tying product or from a third party designated by the supplier of the tying product." VAN BAEL, Ivo V.; BELLIS, Jean-François. Competition Law of the European Community. $4^{\text {th }}$ Edition, Kluwer Law International, 2005, p. 324.

${ }^{368}$ FORGIONI, Paula A. Direito Concorrencial e Restrições Verticais. São Paulo: Editora Revista dos Tribunais, 2007, p. 245.
} 
fornecedor venderá o produto vinculante (tying product) - a fotocopiadora - ao comprador, somente se o comprador adquirir um segundo produto, o produto vinculado (tied product) o toner. ${ }^{369}$ Um exemplo mais moderno sugerido por WHISH seria o do fornecedor de impressora que requer que seus compradores somente utilizem cartuchos de tinta daquele mesmo fornecedor. ${ }^{370}$

Nos termos da Lei 8.884/94, a venda casada vem exemplificada como uma das possíveis infrações à ordem econômica no inciso XXIII, cuja redação é: "subordinar a venda de um bem à aquisição de outro ou à utilização de um serviço, ou subordinar a prestação de um serviço à utilização de outro ou à aquisição de um bem." O inciso XVIII, do parágrafo $3^{\circ}$ do artigo 36 da Lei 12.529/2011 reproduziu esta redação.

Da perspectiva dos fornecedores rivais do produto vinculado (tied product), a venda casada pode ser vista como uma conduta tendente à exclusão, uma vez que o número de potenciais compradores é reduzido em razão de acordos de venda casada firmados por fornecedores em posição dominante. ${ }^{371}$

O Documento Europeu sobre Abusos de Exclusão trata das vendas casadas como "vendas subordinadas e agrupadas". Nos termos do referido documento: "uma empresa dominante pode tentar excluir os seus concorrentes do mercado através de práticas de subordinação e agrupamento de vendas" (item 47). Ainda, de acordo com o documento europeu: "a subordinação refere-se geralmente a situações em que os clientes que compram um produto (produto subordinante) são obrigados a comprar igualmente outro produto da empresa dominante (produto subordinado)."

Os efeitos da prática, de acordo com o documento, são explicados da seguinte forma: "uma empresa que tenha posição dominante num (ou mais) mercado(s) de produtos de uma venda subordinada ou agrupada (referido como mercado subordinante) pode prejudicar os consumidores através de práticas de subordinação ou do agrupamento ao encerrar o mercado em relação a outros produtos que fazem parte da subordinação ou agrupamento

${ }^{369}$ GELLHORN, E.; KOVACIC, W. E.; CALKINS, S.. Antitrust Law and Economics in a Nutshell. 5th Edition. Thompson West, 2004, p. 378.

${ }^{370}$ WHISH, Richard. Competition Law. 5th Edition, LexisNexis Buttersworths, 2005, p. 658.

${ }^{371}$ GAVIL, Andrew I; KOVACIC, William E.; BAKER, Jonathan B. Antitrust Law in Perspective: Cases, Concepts and Problems in Competition Policy. American Casebook Series, Thompson West, Second Edition, 2008 , p. 714. 
(referido como mercado subordinado) e, indirectamente, o mercado subordinante" (item 49).

Conforme explica WHISH, a principal objeção à ideia de acordos de vinculação ou de práticas de venda casada é de que um agente econômico pode aproveitar sua posição dominante com relação ao mercado do produto vinculante para atingir vendas no mercado para o produto vinculado, desta forma, estendendo seu poder de mercado a este segundo mercado. ${ }^{372}$ Como tratado no Capítulo III, a ideia de extensão do poder de mercado ao mercado vinculado ou a teoria da alavancagem (leveraging theory) foi fortemente contestada pela Escola de Chicago. Naquele capítulo, contudo, observamos que alguns autores ligados à tradição pós-Chicago identificaram que objeções poderiam ser feitas quanto à conduta de vendas casadas, em razão do seu potencial de exclusão de concorrentes com relação ao mercado do produto vinculado. Tais autores observaram, ainda, que haveria valor na teoria da alavancagem, quando, por exemplo, um agente econômico em posição dominante no mercado do produto vinculante também tivesse algum poder de mercado com relação ao mercado vinculado, podendo, desta forma, aumentar barreiras à entrada com relação ao mercado vinculado.

Lembremos, ainda, o já mencionado exemplo trazido por HOVENKAMP, que considera que a contestação de Chicago com relação à teoria da alavancagem era excessivamente simples. ${ }^{373}$ Conforme exemplo de HOVENKAMP, uma das discussões envolvendo as condutas da Microsoft com relação à vinculação de sua plataforma (Windows) ao seu Internet browser (Internet Explorer). A preocupação acerca da vinculação, por parte da Microsoft, entre o Windows (mercado de plataforma $=$ mercado vinculante) e o seu Internet Explorer (mercado de browser $=$ mercado vinculado) não seria a de que a Microsoft seria capaz de extrair "duplo lucro de monopólio" ao vincular os dois produtos; a preocupação seria a de que a Microsoft poderia utilizar a sua posição dominante no mercado de plataformas para restringir inovação no mercado de browser e, portanto, prevenir o surgimento de outros concorrentes neste mercado. ${ }^{374}$

\footnotetext{
${ }^{372}$ WHISH, Richard. Competition Law. 6th Edition, LexisNexis Buttersworths, 2008, p. 680.

${ }^{373}$ HOVENKAMP, Herbert. The Antitrust Enterprise: principle and execution. Harvard University Press, Cambridge, Massachusetts; London, England, 2005, p. 35.

${ }^{374}$ HOVENKAMP, Herbert. The Antitrust Enterprise: principle and execution. Harvard University Press, Cambridge, Massachusetts; London, England, 2005, p. 35.
} 
WHISH observa que, hoje, existe uma maior compreensão de que acordos de venda casada são práticas comuns da atividade empresarial e não condutas que devam ser consideradas inerentemente suspeitas. Acordos de vinculação ou venda casada envolvem a integração de componentes em um só produto e esta prática pode resultar em eficiências, resultando em menores custos de produção e distribuição e melhoria na qualidade de produtos. Ainda de acordo com WHISH, as atividades de fabricação de produtos, por sua própria natureza, podem envolver o acoplamento de diferentes componentes e seria inadequado sugerir que, quando tal prática fosse adotada por um agente econômico em posição dominante, ela deveria ser necessariamente estigmatizada como ilícita. ${ }^{375}$

Acordos de vinculação ou práticas de venda casada podem, assim, ser justificados devido à busca de menores custos e de melhoria na qualidade ou desenho de produtos. ${ }^{376} \mathrm{~A}$ venda conjunta dos produtos principal e vinculado pode implicar na diminuição de custos de embalagem e comercialização e pode viabilizar o escoamento de um produto de pouca aceitação. ${ }^{377}$ Finalmente, muitas vezes um agente econômico pode justificar a prática de venda casada com base no argumento de que esta seria necessária para a manutenção da qualidade do produto vinculante. Conforme aponta FORGIONI, no entanto, esta justificativa geralmente não é aceita quando a qualidade do produto ou do serviço poderia ser garantida de outras formas. ${ }^{378}$

\footnotetext{
${ }^{375}$ WHISH, Richard. Competition Law. 6th Edition, LexisNexis Buttersworths, 2008, p. 680.

${ }^{376}$ SALOP, Steven C. Economic Analysis of Exclusionary Vertical Conduct: Where Chicago has Overshot the Mark. In: PITOFSKY, Robert (Ed.). How the Chicago School Overshot the Mark. The Effect of Conservative Economic Analysis of U.S. Antitrust, Oxford University Press, 2008, p. 145.

${ }^{377}$ FORGIONI, Paula A. Direito Concorrencial e Restrições Verticais. São Paulo: Editora Revista dos Tribunais, 2007, p. 252.

${ }^{378}$ FORGIONI, Paula A. Direito Concorrencial e Restrições Verticais. São Paulo: Editora Revista dos Tribunais, 2007, p. 252.
} 


\section{ESTRATÉGIAS DE DISTRIBUIÇÃO MENOS TRADICIONAIS}

\subsection{Introdução}

Como já indicado, a categoria relativa às restrições verticais intermarcas tem sido gradualmente ampliada para incluir não somente as restrições observadas em práticas de distribuição "tradicionais", brevemente tratadas no item anterior, mas também em outros tipos de estratégias, menos convencionais, destinadas a incrementar vendas ou atingir algum grau de exclusividade por parte de fornecedores. ${ }^{379}$ Como exemplo dos tipos menos tradicionais de práticas de distribuição que envolvem restrições verticais, podemos identificar os vários tipos de descontos (e.g. descontos de fidelidade, descontos em pacote (bundling), descontos ligados a metas de vendas), estratégias promocionais e estratégias de alocação de produtos em prateleiras.

Nos próximos tópicos, focaremos, inicialmente, nas práticas de descontos e, em seguida, trataremos de outras estratégias de distribuição menos tradicionais.

\subsection{Descontos}

Descontos são fatos comuns da vida empresarial e podem configurar formas legítimas e desejáveis de concorrência, por meio das quais fornecedores buscam atrair clientes para si. ${ }^{380}$ Conforme anota HOVENKAMP, descontos configuram uma prática comercial antiga, por meio da qual comerciantes induzem seus compradores a adquirir deles - e não de seus concorrentes -, ou ainda, fazem que compradores adquiram mais do que de outra forma o fariam; a vasta maioria dos descontos seria, dessa forma, resultado de negociações legítimas. ${ }^{381}$

Fornecedores utilizam uma ampla variedade de práticas de preços e de descontos com o objetivo de aumentar sua participação de mercado e reter clientela. Em princípio, tais

\footnotetext{
${ }^{379}$ GAVIL, Andrew I. Exclusionary Distribution Strategies by Dominant Firms: Striking a Better Balance. In: Antitrust Law Journal, V. 72, 2004, p. 9

${ }^{380}$ Conforme afirma HOVENKAMP: "Discounting is a pervasive feature of the American economy. Firms offer discounts if the buyer takes three instead of one, agrees to purchase all of its needs from the seller, or takes both the stereo receiver and the speakers together. Discounts make buyers feel good, they help sellers sell more, and they serve the far more jejune purpose of reducing transaction costs." HOVENKAMP, Herbert. The Antitrust Enterprise: principle and execution. Harvard University Press, Cambridge, Massachusetts; London, England, 2005, p. 170.

381 "Discounts are the old-age way that merchants induce customers to purchase from them and not from someone else or to purchase more than they otherwise would. The vast majority of them reflect hard bargaining." HOVENKAMP, Herbert. Discounts and Exclusion. In: Utah Law Review, n. 3, 2006, p. 843.
} 
descontos tipicamente conduzem a preços mais baixos, o que deveria, na maioria dos casos, trazer a presunção de que seriam benéficos à concorrência. ${ }^{382}$ Não obstante, as práticas de concessão de descontos têm sido objeto de diversas investigações nos Estados Unidos e na Europa, em casos envolvendo investigações de abuso de posição dominante, em razão de seu potencial de exclusão.

A identificação das circunstâncias em que descontos estabelecidos por agentes econômicos em posição dominante podem configurar uma conduta anticompetitiva não é tarefa simples. Em nosso entendimento, a variedade de regimes de descontos sugere que a análise deve ser baseada nos fatos e depende das circunstâncias específicas de cada caso. ${ }^{383}$

Há uma variedade de tipos de descontos que podem ser estabelecidos por fornecedores na tarefa da distribuição. Uma das dificuldades no tratamento dos descontos, de forma geral, diz respeito ao fato de que eles têm traços comuns com outras práticas de distribuição envolvendo restrições verticais, cujos contornos e forma de tratamento estão mais consolidados no repertório do antitruste. A tentativa de aproximação com as restrições verticais "tradicionais", no entanto, não é necessariamente adequada, ou mesmo útil, em muitas circunstâncias, uma vez que os descontos têm também traços que os distinguem destas práticas. A seguir, trataremos dos tipos mais frequentes de descontos discutidos pela literatura antitruste e de algumas controvérsias teóricas trazidas por sua análise.

\footnotetext{
${ }^{382}$ Conforme TEMPLE LANG e O'DONOGHUE: "There is no obvious reason why antitrust law should view such practices with any particular suspicion, since they typically lead to lower prices, which should in nearly all cases benefit from strong presumption of legality." TEMPLE LANG, John; O'DONOGHUE, Robert. Defining Legitimate Competition: How to Clarify Pricing Abuses under Article 82 EC. In: Fordham International Law Journal, v. 26, 2002-2003, p. 91. STEUER afirma que o direito da concorrência é geralmente favorável a descontos: "Antitrust normally loves discounts, so long as they do not cause unlawful discrimination or drop prices below "cost"; and antitrust normally is hospitable toward exclusive dealing arrangements, so long as they do not foreclose too much of the market. But antitrust hates discounts offered to induce exclusive dealing when they unreasonably threaten to foreclose competition." STEUER, Richard. Discounts and Exclusive Dealing. In: Antitrust Magazine, v. 7, Spring 1993, p. 28.

${ }^{383}$ Neste sentido, ver AMERICAN BAR ASSOCIATION. Section of Antitrust Law. Antitrust Law Developments, ABA Book Publishing, $6^{\text {th }}$ Edition, 2007, p. 252. Acerca da dificuldade na análise de descontos, vale conferir HOVENKAMP: "Discounting practices have been particularly problematic in recent years. The law seems to be in roughly the same position that the law of predatory pricing was in the seventies and eighties." HOVENKAMP, Herbert. The Harvard and Chicago School and the Dominant Firm. In: PITOFSKY, Robert (Ed.). How the Chicago School Overshot the Mark. The Effect of Conservative Economic Analysis of U.S. Antitrust, Oxford University Press, 2008, p. 120.
} 


\subsubsection{Descontos por volume}

Um exemplo de descontos simples são os descontos vinculados ao volume de produtos adquiridos pelo comprador. O tratamento dado pelo direito da concorrência aos descontos por volume é geralmente benéfico. Isto porque, em princípio, simples descontos por volume não restringem diretamente a possibilidade de que o comprador adquira também de outros fornecedores, pois geralmente não estão condicionados a um compromisso por parte do comprador de não adquirir - ou de restringir a aquisição de produtos/serviços de outros fornecedores. ${ }^{384}$ Assim, o potencial de exclusão da maioria dos descontos por volume pode ser inexistente.

HOVENKAMP afirma que descontos por volume são quase sempre pro-competivos, a não ser que possam configurar uma situação de exclusividade; ainda assim, o autor afirma que, na maioria das circunstâncias, a exclusividade em si é uma prática que não necessariamente causa prejuízos à concorrência. ${ }^{385}$

Alguns descontos por volume, no entanto, são mais complexos e estão vinculados ao percentual adquirido pelo comprador em relação à totalidade de suas compras, ou seja, à obrigação de que o comprador adquira um determinado percentual do total de suas compras do fornecedor que os estabelece. ${ }^{386}$ Este tipo de desconto é referido pela doutrina norteamericana e europeia como "market share discount" 387 ou "percentage quantity discount". ${ }^{388} \mathrm{O}$ efeito destes regimes é que eles não somente criam um incentivo para que o comprador adquira mais do fornecedor que estabelece o desconto, mas também criam um incentivo para que o comprador restrinja o percentual de aquisição de serviços/produtos de

\footnotetext{
384 "Compared do share-based discounts, volume-based discounts are generally less restrictive because they do not restrain the buyer from buying any volume they wish from the defendant's rivals, and they are more closely related to possible volume-based efficiencies". ELHAUGE, Einer; GERADIN, Damien. Global Competition Law and Economics. Oxford and Portland: Hart Publishing, 2007, p. 572.

${ }^{385}$ HOVENKAMP, Herbert. The Antitrust Enterprise: principle and execution. Harvard University Press, Cambridge, Massachusetts; London, England, 2005, p. 171-172.

${ }^{386} \mathrm{Um}$ fornecedor pode, por exemplo, condicionar a concessão de descontos a um compromisso do comprador de que este adquirirá $70 \%$ do total de suas aquisições daquele fornecedor. Neste exemplo, somente $30 \%$ do total de suas aquisições poderia ser buscado de outras fontes (de outros fornecedores).

${ }^{387}$ TOM, Williard K; BALTO, David A.; AVERITT, Neil W. Anticompetitive Aspects of Market ShareDiscounts and Other Incentives to Exclusive Dealing. In: Antitrust Law Journal, v. 67, 2000, p. 615.

${ }^{388}$ STEUER, Richard. Discounts and Exclusive Dealing. In: Antitrust Magazine, v. 7, Spring 1993, p. 30.
} 
fornecedores rivais. Neste contexto, portanto, tais descontos podem ter o potencial efeito de excluir fornecedores concorrentes. ${ }^{389}$

\subsubsection{Descontos de fidelidade}

Outra técnica de descontos frequentemente utilizada por fornecedores na distribuição de seus produtos/serviços envolve os chamados "descontos de fidelidade". Em linhas gerais, descontos de fidelidade são descontos condicionados a que o comprador adquira todas ou uma parte de seus suprimentos de um determinado produto de apenas um fornecedor ou de adquirir a maior parte ou um percentual significativo de seus suprimentos daquele fornecedor. ${ }^{390}$ Geralmente, este tipo de desconto refere-se a apenas um tipo de produto. ${ }^{391}$ Descontos de fidelidade, em regra, não estão relacionados ao volume ou à quantidade adquirida; eles são concedidos aos compradores como forma de recompensa por sua fidelidade ao fornecedor. ${ }^{392}$

Os descontos de fidelidade são, por vezes, tratados como formas de exclusividade de fato. A este respeito, vale notar que o Documento Europeu sobre Abusos de Exclusão refere-se descontos condicionais na seção que trata de acordos exclusivos. Nos termos do documento: "os descontos condicionais são descontos concedidos a clientes para os recompensar por um comportamento de compra específico". O documento explica, ainda, que "as empresas podem oferecer este tipo de desconto para atraírem os clientes e, desta forma, podem estimular a procura e beneficiar os consumidores." O documento prossegue, fazendo uma advertência: "este tipo de desconto - quando oferecido por empresas dominantes - pode produzir efeitos efectivos ou potenciais de encerramento semelhantes

\footnotetext{
${ }^{389}$ A jurisprudência européia traz exemplos, ainda, de descontos por compras marginais ("top slice" ou "marginal tonnage"), por meio dos quais um fornecedor estabelece um preço mais baixo ou um desconto para as aquisições que excederem o volume básico usualmente adquirido pelos compradores. Este sistema teria o efeito de evitar que o comprador buscasse em fontes alternativas o restante de suas aquisições. Quando o fornecedor já tem uma base assegurada de vendas a alguns compradores, fornecedores concorrentes têm dificuldade em concorrer por ser a "segunda fonte" de aquisições do comprador.VAN BAEL, Ivo V.; BELLIS, Jean-François. Competition Law of the European Community. $4^{\text {th }}$ Edition. Kluwer Law International, 2005 , p. 924.

${ }^{390}$ Conforme definição em Hoffman-La Roche: “discounts conditional on the customer's obtaining all or most of its requirements - whether the quantity of its purchases be large or small - from the undertaking in a dominant position." Hoffman-La Roche v. Commission, [1979] ECR 461 (para. 89).

${ }^{391}$ STEUER, Richard M. Bundles of Joy. In: Antitrust, v. 22, n. 2, Spring 2008.

392 Conforme JONES e SUFFRIN: "Loyalty (or fidelity) rebates are discounts given to a customer as a reward for loyalty to the supplier. They are given not because the customer has brought a certain objective amount from the supplier but because he has not bought from others." JONES, Alison; SUFFRIN, Brenda. EC Competition Law - Text, Cases and Materials. Oxford University Press, 2001, p. 358.
} 
aos das obrigações de compra exclusiva". Por fim, o documento esclarece que "os descontos condicionais podem produzir esses efeitos sem constituírem necessariamente um sacrifício para a empresa dominante" (item 37).

A jurisprudência europeia já tratou de descontos por fidelidade como formas de exclusividade em alguns casos conhecidos, entre eles: o caso Hoffman La-Roche ${ }^{393}$, decidido pela a Corte de Justiça Européia em 1979; o caso British Airways ${ }^{394}$, decidido pela Comissão Europeia em 2000; e o caso Michelin II ${ }^{395}$, decidido pela Corte de Primeira Instância, em 2003. De forma semelhante, a jurisprudência norte-americana também já tratou descontos de fidelidade como casos de exclusividade em algumas situações, entre elas, no caso United Shoe Machinery Corp. ${ }^{396}$, de 1922, e no caso Tampa Electric Co. v. Nashville Coal Co., de 1961.

\subsubsection{Descontos em pacote (bundled discounts)}

Outra técnica usualmente utilizada por fornecedores no âmbito da distribuição são os chamados descontos em pacote ("bundled discounts"). Tais descontos envolvem o oferecimento de descontos ou outros incentivos aplicáveis a um grupo ou pacote (bundle) de produtos. Estes descontos podem ser descritos como estratégias de preço utilizadas por fornecedores para oferecer aos seus compradores um grupo atrativo de produtos e, desta forma, aumentar o volume de compras de determinados produtos acima do nível que provavelmente seria esperado, caso o preço dos produtos fosse determinado separadamente. $^{397}$

WHISH conceitua os descontos em pacote como situações em que um agente econômico vende dois ou mais produtos conjuntamente, como um pacote, e cobra um preço

\footnotetext{
${ }^{393}$ Hoffman La-Roche \& Co. AG v. Comission, Caso 85/76 [1979] ECR 461. Nos termos do parágrafo 89, uma empresa que ocupasse posição dominante não poderia vincular um comprador por uma obrigação de aquisição exclusiva e o mesmo se aplicaria a sistemas de descontos de fidelidade: "The same applies if said undertaking, without tying the purchasers by a formal obligation, applies, either under the terms of the agreements concluded with these purchasers or unilaterally, a system of fidelity rebates, that is to say discounts conditional on the customer's obtaining all or most of its requirements - whether the quantity of its purchases be large or small - from the undertaking in a dominant position."

${ }^{394}$ British Airways v. Commission, Caso T-219/99.

395 CFI, Manufacture Française des Pneumatiques Michelin v. Commission of 30 September 2003, Case T203/01.

${ }^{396}$ United Shoe Machinery v. United States, 258 U.S., 258 U.S. 451, 255 (1922), conforme relatado por STEUER, Richard M. Discounts and Exclusive Dealing. In: Antitrust Magazine, v. 7, Spring 1993, p. 29.

397 JAECKEL, Jeffrey A. Le Page's, Cascade Health Solutions, and a Bundle of Confusion: What is a Discounter to do? In: Antitrust, Summer 2010, Volume 24, Number 3, p. 46.
} 
para o conjunto de produtos mais atrativo do que os preços que seriam cobrados pelas partes do conjunto. ${ }^{398}$ HOVENKAMP reforça que os descontos em pacote são aqueles que se aplicam de forma agregada a dois ou mais produtos; ou seja, não basta que o desconto seja aplicado a dois ou mais produtos, mas que seja aplicado de forma agregada. ${ }^{399}$

WHISH menciona um caso em que a Comissão Europeia teria se oposto a uma situação em que uma determinada empresa oferecia preços que eram mais atrativos quando os compradores adquiriam serviços de software em conjunto com serviços de hardware, do que quando os serviços de software eram adquiridos separadamente. ${ }^{400}$ Ainda, menciona o caso De Poste-La Poste, em que a Comissão Europeia impôs uma multa à empresa de correios belga por oferecer preços mais baixos no mercado pela entrega de cartas, caso os seus clientes também utilizassem um segundo serviço (serviço de business-to-business) oferecido pela empresa.

Por outro lado, em caso decidido pela autoridade de defesa da concorrência do Reino Unido, também mencionado por WHISH, o Office of Fair Trading considerou que a prática adotada pela empresa $B S k y B$ de oferecer em conjunto canais premium de esportes e de filmes não teria violado as normas concorrenciais daquele país, pois considerou que não houve resultados anticoncorrenciais decorrentes da prática, uma vez que não teria havido fechamento de mercado a seus concorrentes. Esta decisão ilustra o ponto de que, em princípio, o comportamento de um agente econômico em posição dominante somente deve ser considerado abusivo quando tiver o potencial de causar efeitos anticoncorrenciais. ${ }^{401}$

Conforme explica STEUER ${ }^{402}$, as motivações comerciais para a utilização desta técnica de distribuição são facilmente explicáveis, tanto do ponto de vista do fornecedor, quanto do ponto de vista do comprador dos produtos aos quais se aplicam os descontos. Do ponto de vista do fornecedor, programas de descontos em pacote podem permitir que os fornecedores reduzam seus preços, contanto que os programas resultem em um maior número de vendas. Tais programas podem permitir aos fornecedores, ainda, uma

\footnotetext{
${ }^{398}$ WHISH, Richard. Competition Law. 6th Edition, LexisNexis Buttersworths, 2008, p. 728.

${ }^{399}$ HOVENKAMP, Herbert. The Law of Exclusionary Pricing. In: Competition Policy International, v. 2, n. 1. Spring, 2006, p. 29.

${ }^{400}$ Conforme relatório da Comissão Europeia Commission's XXVIIth Report on Competition Policy (1997), p. 153-154, apud WHISH, Richard. Competition Law. 6th Edition, LexisNexis Buttersworths, 2008, p. 728.

${ }^{401}$ Decisão do Office of Fair Trading, datada de 17 de dezembro de 2002, [2003] UKCLR 240.

${ }^{402}$ STEUER, Richard. Bundling Beyond Borders. In: Antitrust, Summer 2010, v. 24, n. 3, p. 40.
} 
possibilidade de igualar ofertas de fornecedores rivais ou mesmo de tentar introduzir novos produtos no mercado. Por outro lado, compradores, com frequência, buscam descontos em pacote com vistas a obter preços favoráveis aos seus suprimentos/compras.

Diante da racionalidade comercial deste tipo de desconto, pode-se afirmar que eles são relativamente comuns em diversos mercados e tipos de indústria. Conforme aponta STEUER, ainda, decisões importantes da jurisprudência norte-americana recente envolveram produtos e mercados variados, tais como vitaminas, pneus, viagens aéreas, produtos farmacêuticos, equipamentos médicos, serviços hospitalares e equipamentos de escritórios. ${ }^{403}$ Ainda, uma decisão recente da jurisprudência dos Estados Unidos acerca do tema reconhece que este tipo de técnica é adotada tanto por grandes fornecedores, que oferecem um grande portfolio de produtos, quanto por pequenos comerciantes, que podem oferecer descontos em grupo para o limitado número de produtos que oferecem. ${ }^{404}$

A literatura antitruste acerca dos efeitos concorrenciais dos descontos em pacote ainda é, no mínimo, inconclusiva, ${ }^{405}$ não obstante a sua racionalidade econômica, a frequência com que são empregados, a variedade de produtos e mercados em que se verificam e a diversidade de tamanho dos fornecedores que os adotam.

HOVENKAMP considera que, apesar de a prática de descontos em pacote ter o potencial de excluir determinados rivais, ela somente seria um ilícito de exclusão caso nenhum rival significativo pudesse oferecer um pacote semelhante ao oferecido pelo agente econômico em posição dominante. Assim, a estratégia do fornecedor em posição dominante somente faria sentido como tendo potencial de exclusão se não fosse possível a outros fornecedores oferecer todos os produtos do pacote, porém apenas alguns deles. ${ }^{406}$

Os "descontos em pacote" têm algumas semelhanças com as práticas de venda casada ou acordos de vinculação, brevemente tratados no item anterior. Há, no entanto,

\footnotetext{
${ }^{403}$ STEUER, Richard. Bundling Beyond Borders. In: Antitrust, Summer 2010, v. 24, n. 3, p. 40.

404 "The world's largest corporations offer bundled discounts as their product lines expand with the convergence of industries... [and] a street corner vendor with a food cart - a merchant with limited capital might offer a discount to a customer who buys a drink and potato chips to complement a hot dog". Cascade Health Solutions v. PeaceHealth, 502, F.3d 895, 905 (9 $9^{\text {th }}$ Circ. 2007).

${ }^{405}$ Conforme constata BAKER: “(...) the legal rules that apply to bundled discounts are not settled." BAKER, Jonathan B.. Preserving a Political Bargain: The Political Economy of the Non-Interventionist Challenge to Monopolization Enforcement. In: Antitrust Law Journal, v. 76, n. 3, 2010, p. 615.

${ }^{406}$ HOVENKAMP, Herbert. The Law of Exclusionary Pricing. In: Competition Policy International, v. 2, n. 1. Spring, 2006, p. 29-30.
} 
considerável controvérsia doutrinária, principalmente entre os autores norte-americanos, acerca de qual o padrão de análise deve ser utilizado nestes casos. No próximo tópico, trataremos brevemente desta controvérsia.

\subsubsection{Descontos em pacote como prática predatória ou como forma de venda casada}

Como dito, alguns autores consideram que os descontos em pacote levantam questões semelhantes aos acordos de venda casada ou de vinculação (tying) ${ }^{407}$ e, de fato, alguns casos da jurisprudência norte-americana tratam de descontos em pacote sob esta perspectiva. $^{408}$

O Documento Europeu sobre Abusos de Exclusão inclui, na mesma seção, as "vendas casadas" e os "descontos multi-produtos", o que sugere que a Comissão poderá considerar tais descontos como assemelhados às vendas casadas (itens 59-62). De acordo com o documento: "a prática de um desconto multi-produtos pode ser considerada anticoncorrencial nos mercados subordinado e subordinante se o desconto for tal que impeça os concorrentes com o mesmo grau de eficiência, que oferecem apenas alguns dos componentes, de concorrer com o grupo de produtos que beneficia do desconto" (item 59).

Outros autores consideram que os "descontos em pacote" podem também aproximar-se da prática de preços predatórios. ${ }^{409}$ Neste sentido, vale também notar que o Documento Europeu sobre Abusos de Exclusão não afasta a possibilidade de que tais descontos sejam tratados como forma de preços predatórios. Nos termos do referido documento: "se as provas sugerirem que os concorrentes da empresa dominante vendem grupos de produtos semelhantes, ou poderiam fazê-lo rapidamente sem serem dissuadidos por eventuais custos adicionais, a Comissão considerará, em geral, que se está perante uma situação de concorrência entre grupos de produtos. Nesse caso, a questão relevante não é a de verificar se as receitas marginais cobrem os custos marginais de cada produto do grupo, mas se o preço do grupos de produtos constitui no seu conjunto um preço predatório" (item 61).

\footnotetext{
${ }^{407}$ WHISH, Richard. Competition Law. 6th Edition, LexisNexis Buttersworths, 2008, p. 728. ELHAUGE, Einer; GERADIN, Damien. Global Competition Law and Economics. Oxford and Portland: Hart Publishing, 2007, p. 572. STEUER, Richard. Bundling Beyond Borders. In: Antitrust, Summer 2010, v. 24, n. 3, p. 40.

${ }^{408}$ A este respeito, ver ELHAUGE, Einer; GERADIN, Damien. Global Competition Law and Economics. Oxford and Portland: Hart Publishing, 2007, p. 595.

${ }^{409}$ STEUER, Richard. Bundling Beyond Borders. In: Antitrust, Summer 2010, Volume 24, Number 3, p. 40.
} 
Conforme sumariza HOVENKAMP, nos Estados Unidos, em casos relacionados a descontos em pacote aplicados por fornecedores em posição dominante, os autores (das ações judiciais) têm buscado caracterizar a prática como configurando uma forma de venda casada, enquanto que os agentes econômicos cuja prática está sendo questionada buscam caracterizá-la como preços predatórios. ${ }^{410}$ Isto porque, como já vimos, os testes para a demonstração de ocorrência de preços predatórios, utilizados na jurisprudência norteamericana, são bem mais difíceis de serem demonstrados do que os relativos a práticas de distribuição tendentes à exclusão "não ligadas a preço", tais como a venda casada.

Em linha semelhante, GAVIL, KOVACIC e BAKER observam que nos termos da jurisprudência norte-americana, casos relacionados a condutas de exclusão "não ligadas a preço" (tais como a venda casada) seriam de demonstração mais fácil. Na explicação dos autores, em casos envolvendo comportamentos de exclusão "não ligados a preço", seria necessário que os autores demonstrassem a exclusão ou o prejuízo aos rivais e suas consequências reais ou prováveis aos consumidores; os agentes dominantes cuja conduta estaria sendo questionada deveriam, então, trazer justificativas comerciais para seus comportamentos, o que sugere que os tribunais deveriam fazer algum tipo de avaliação entre efeitos e justificativas. ${ }^{411}$

Os autores explicam que há, hoje, nos Estados Unidos, uma tensão entre os padrões relacionados à forma de análise nos moldes do exame de preços predatórios, de um lado, e de práticas de exclusão não ligadas a preço, de outro. Como dito, enquanto os padrões utilizados para demonstrar a ocorrência de preços predatórios são difíceis de atingir, algumas decisões demonstram que os padrões para demonstrar ilicitude de condutas de exclusão não ligadas a preços seriam de mais fácil comprovação. A escolha de qual padrão de análise deve ser utilizado, portanto, pode ter um impacto no resultado dos casos.

Em recente artigo, SALOP sumariza o que entende ser dois distintos paradigmas para a análise de condutas de exclusão por agentes econômicos em posição dominante: o padrão relacionado à análise de preços predatórios e o padrão relacionado à teoria do

\footnotetext{
${ }^{410}$ HOVENKAMP, Herbert. The Law of Exclusionary Pricing. In: Competition Policy International, v. 2 , n. 1. Spring, 2006, p. 30.

${ }^{411}$ GAVIL, Andrew I; KOVACIC, William E.; BAKER, Jonathan B. Antitrust Law in Perspective: Cases, Concepts and Problems in Competition Policy. American Casebook Series, Thompson West, Second Edition, 2008, p. 680 e seguintes.
} 
aumento dos custos dos rivais. ${ }^{412}$ SALOP diagnostica que grande parte da controvérsia sobre os padrões a serem aplicados a casos envolvendo condutas de exclusão é explicada devido ao fato de que alguns autores e tribunais têm um ou outro paradigma como referência para a análise destes comportamentos.

Na visão de SALOP, a utilização do paradigma de preços predatórios conduz a uma visão extremamente permissiva de condutas de exclusão e muito cética acerca de alegações de aspectos anticompetitivos destas condutas. SALOP considera, portanto, que é importante frisar a distinção entre os dois padrões e argumenta que a compreensão das condutas de exclusão sob a perspectiva da teoria do aumento dos custos dos rivais é capaz de identificar com maior clareza situações em que há maior probabilidade de prejuízo à concorrência.

Nesse sentido, SALOP argumenta que uma das vantagens de se adotar a linha teórica relacionada ao aumento de custos dos rivais é que esta não requer um investimento arriscado ou associado a qualquer tipo de "sacrifício de lucros" por parte do agente dominante durante um período inicial de "predação". Outras vantagens mencionadas por SALOP são: uma estratégia bem sucedida de aumento dos custos dos rivais não requer que os concorrentes sejam, de fato, excluídos do mercado, mas apenas que seus custos sejam aumentados; e, ao contrário do padrão de análise relacionado aos preços predatórios, o aumento dos custos dos rivais não envolve um benefício ao consumidor a curto prazo (i.e. preços baixos) que precise ser sopesado com referência a um prejuízo ao consumidor a longo prazo.

Dois exemplos da jurisprudência norte-americana ilustram a controvérsia acerca de qual padrão deve ser adotado no caso de descontos em pacote: o caso LePage Inc's v. $3 M$ Company (2003) ${ }^{413}$ e o caso Cascade Health Solutions v. Peacehealth $(2007)^{414}$.

De acordo com os fatos do caso, LePage's Inc., um fornecedor de fitas transparente questionou o programa de descontos de sua rival $3 M$ Company, por meio do qual a $3 M$ oferecia descontos significativos para os consumidores que adquirissem em conjunto suas

\footnotetext{
${ }^{412}$ SALOP, Steven C. Economic Analysis of Exclusionary Vertical Conduct: Where Chicago has Overshot the Mark. In: PITOFSKY, Robert (Ed.). How the Chicago School Overshot the Mark. The Effect of Conservative Economic Analysis of U.S. Antitrust, Oxford University Press, 2008, p. 142.

${ }^{413}$ LePage Inc's v. 3 M Company, 324 F.3d 141 (3d Cir. 2003), cert. denied, 542 U.S. 953 (2004).

${ }^{414}$ Cascade Health Solutions v. PeaceHealth, 502 F.3d 895 (9th Cir. 2007).
} 
fitas transparentes em conjunto com outros de seus produtos. ${ }^{415}$ LePage fornecia apenas um produto - fita transparente - e argumentava que o programa da $3 M$ resultava em que os compradores deixassem de adquirir os seus produtos e adquirissem os produtos da $3 \mathrm{M}$. Em razão da estrutura de descontos da $3 M$, LePage alegava que um comprador que optasse por adquirir fita transparente da LePage perderia os descontos oferecidos pela $3 M$ para todas as linhas de produto da $3 M$ que faziam parte do programa, e não somente com relação ao produto "fita transparente". LePage argumentava que os descontos em pacote oferecidos pela $3 M$ teriam tido o efeito de excluir a LePage do mercado de fitas transparentes, o que, ao final, teria resultado em preços mais altos aos consumidores após a sua saída do mercado. A corte distrital não aceitou as justificativas da $3 M$ para o seu programa de descontos e considerou que a $3 M$ teria violado a Seção 2 do Sherman Act.

A $3 M$ construiu a sua defesa a partir de argumentos relacionados à inexistência da prática de preços predatórios. Neste sentido, argumentou que os descontos em pacote permaneceram acima da medida de custo apropriada e que, portanto, o programa não teria violado a Seção 2 do Sherman Act. Especificamente, a $3 M$ argumentou que, ainda que fosse considerada monopolista com relação a um dos seus produtos, seus descontos não poderiam ser considerados predatórios, pois estes não reduziriam o preço do produto objeto do monopólio abaixo de custo. Ou seja, a $3 M$ argumentava que o preço do produto monopolizado, um dos produtos do pacote, não seria abaixo do custo, mesmo que o desconto inteiro fosse atribuído somente a este produto. A corte do $3^{\circ}$ circuito, no entanto, concluiu que a acusação não envolvia uma conduta de preço predatório e, ainda, que o simples fato de que uma estratégia de preços ter sido questionada não converteria o caso em um caso de preços predatórios. Não houve, portanto, a necessidade de que LePage demonstrasse que a $3 M$ havia estabelecido preços abaixo do custo de forma que estivesse em uma posição de recuperar perdas.

Já no caso Cascade Health Solutions v. Peacehealth (2007), a corte do $9^{\circ}$ Circuito concluiu que descontos em pacote seriam parte importante das atividades comerciais regulares das empresas e, portanto, poderiam ser pró-competitivos. Por este motivo, tais

\footnotetext{
${ }^{415}$ Descrição dos fatos conforme feita por GAVIL, Andrew I; KOVACIC, William E.; BAKER, Jonathan B. Antitrust Law in Perspective: Cases, Concepts and Problems in Competition Policy. American Casebook Series, Thompson West, 2008, p. 681 e 682.
} 
práticas não poderiam ser tratadas sem padrões claros e adotou um teste diverso do adotado no caso LePage, mencionado acima. O tribunal considerou que uma violação à Seção 2 do Sherman Act não poderia ser constatada com relação a descontos em pacote, a não ser que o desconto resultasse em preços que seriam abaixo de uma medida adequada de custos do fornecedor que os estabeleceu. ${ }^{416} \mathrm{O}$ tribunal, portanto, adotou um padrão semelhante ao utilizado para casos de preços predatórios.

As decisões proferidas nos dois casos, aparentemente inconsistentes, originaram uma controvérsia sobre quais os padrões a serem utilizados em ilícitos de monopolização, ou seja, se deveria ser utilizado um padrão semelhante à análise de preços predatórios ou um padrão geralmente utilizado com relação a "condutas não ligadas a preço", tal como a venda casada ou outras condutas de exclusão. Conforme anotam GAVIL, KOVACIC e BAKER, esta controvérsia ilustra uma "guerra de classificação" acerca de como os casos envolvendo descontos em pacote devem ser examinados nos Estados Unidos. ${ }^{417}$

Vale notar que, muitos dos testes sugeridos pela literatura norte-americana mais recente, referidos no item 4 do Capítulo III, buscam justamente trazer luz a esta e outras controvérsias envolvendo abusos de posição dominante diante das estratégias de distribuição menos tradicionais.

\subsection{Outras estratégias de distribuição não tradicionais}

Além dos sistemas de descontos, outras estratégias de distribuição menos tradicionais podem ter efeitos de exclusão.

Sistemas de pagamento de comissões e bônus, por exemplo, são geralmente tratados da mesma forma que regimes de incentivos implementados por meio de descontos, quando aqueles forem estruturados de forma a obter resultados semelhantes. ${ }^{418}$

Ainda, outras práticas têm sido objeto de discussão, principalmente nos Estados Unidos, com relação ao que WRIGHT chama de "concorrência pela distribuição". 419

\footnotetext{
416 “.... the exclusionary conduct element of a claim arising under paragraph 2 of the Sherman Act cannot be satisfied by reference to bundled discounts unless the discounts result in prices that are below an appropriate measure of the defendant's costs". (itens 906-907 da decisao)

${ }^{417}$ GAVIL, Andrew I; KOVACIC, William E.; BAKER, Jonathan B. Antitrust Law in Perspective: Cases, Concepts and Problems in Competition Policy. American Casebook Series, Thompson West, 2008, p. 682.

${ }^{418}$ VAN BAEL, Ivo V.; BELLIS, Jean-François. Competition Law of the European Community. $4^{\text {th }}$ Edition. Kluwer Law International, 2005, p. 922, nota 63.
} 
WRIGHT define a concorrência pela distribuição como aquela que envolve atividades de contratação entre fornecedores e varejistas acerca de decisões sobre a comercialização, promoção ou posicionamento de um determinado produto. ${ }^{420}$

Como já tivemos oportunidade de tratar de forma mais detida em outro trabalho ${ }^{421}$, no âmbito da concorrência pela distribuição, observa-se uma ampla gama de arranjos por meio dos quais fornecedores buscam assegurar espaço em prateleiras de estabelecimentos varejistas para estoque e exposição de seus produtos. Estes acordos podem envolver obrigações assumidas pelos estabelecimentos varejistas, para que estes dediquem uma proporção determinada ou localização estratégica de prateleira para determinada marca, ou que dediquem seu espaço de prateleira exclusivamente para uma marca. Em linhas gerais, estas práticas - geralmente chamadas de slotting allowances ou slotting fees - envolvem arranjos promocionais e pagamentos feitos por fornecedores para que os estabelecimentos varejistas reservem espaço destacado em suas prateleiras para exposição de seus produtos. $^{422}$

Os benefícios comerciais destes acordos estão geralmente associados à introdução de novos produtos no mercado. Os pagamentos feitos por fornecedores a varejistas facilitariam a introdução de novos produtos no mercado varejista, uma vez que oferecem uma espécie de garantia ou compensação ao varejista pelos custos e riscos de comercialização e exposição de um novo produto, cujo sucesso de mercado ainda não tenha sido testado. 423

\footnotetext{
${ }^{419}$ WRIGHT, Joshua D. Antitrust Law and Competition for Distribution. In: Yale Journal on Regulation, v. 23, n. 2, Summer 2006, p. 170.

${ }^{420}$ No original: “...manufacturer and retailer contracting activity regarding the decision to carry, promote, or place a particular product". WRIGHT, Joshua D. Antitrust Law and Competition for Distribution. In: Yale Journal on Regulation, v. 23, n. 2, Summer 2006, p. 170.

${ }^{421}$ CORRÊA, Mariana Villela. Exclusividade e Direito da Concorrência. Dissertação de Mestrado apresentada ao Departamento de Direito Comercial, Universidade de São Paulo, Faculdade de Direito, São Paulo, 2008.

422 "Slotting allowances are payments made by a manufacturer to a retailer to obtain or retain shelf space for its products." AMERICAN BAR ASSOCIATION. Section of Antitrust Law. Antitrust Law and Economics of Product Distribution. American Bar Association, 2006, p. 292.

${ }^{423}$ Conforme relatório elaborado pela Federal Trade Commission. FEDERAL TRADE COMMISSION. Report on the Federal Trade Commission Workshop on Slotting Allowances and Other Marketing Practices in the Grocery Industry, a Report by Federal Trade Commission Staff, February 2001. ("Relatório FTC 2001"), p. 12-16. Em sentido semelhante, HOVENKAMP: "The main function of slotting fees is to transfer risk from the retailer to the manufacturer. ...Thus the slotting fee shows the merchant that the manufacturer's
} 
KLEIN e WRIGHT sugerem que, ao oferecer espaço em suas prateleiras, os varejistas oferecem uma espécie de "serviço promocional". De acordo com este argumento, arranjos que envolvem o pagamento por fornecedores a varejistas por espaço em prateleiras servem como forma de remunerar os varejistas pelo fornecimento destes serviços promocionais. Nesta linha, os estabelecimentos varejistas podem ser vistos como detentores de um ativo (espaço em prateleiras) que pode influenciar as vendas dos fornecedores. Fornecedores concorrem por este ativo, e esta concorrência pode levar a arranjos contratuais por meio dos quais os fornecedores pagam aos varejistas pelo uso deste ativo. 424

Há uma preocupação, no entanto, de que estes pagamentos aumentem o custo de entrada de fornecedores em determinadas indústrias, com potencial efeito de exclusão. Alguns arranjos podem vincular uma proporção tão alta do espaço em prateleiras a um só fornecedor, em tantos pontos de venda, que podem ter efeitos semelhantes aos de exclusividade, com o fechamento do "espaço de prateleira" para fornecedores menores. ${ }^{425}$

A principal preocupação concorrencial associada aos pagamentos por espaço em prateleira, portanto, refere-se à possibilidade de fornecedores em posição dominante utilizarem estes arranjos como forma de criar desvantagens a outros fornecedores, aumentando seus custos de entrada e fechando o mercado a pequenos fornecedores, consequentemente, aumentando os preços aos consumidores finais. Conforme aponta WRIGHT, a maior parte dos casos investigados pelas autoridades antitruste norteamericanas a respeito dos chamados slotting contracts, refere-se à preocupação de que fornecedores em posição dominante possam se utilizar destes pagamentos para fechar o "espaço de prateleira" a fornecedores rivais. ${ }^{426}$

promise of good sales is more than empty words." HOVENKAMP, Herbert. The Antitrust Enterprise. Principles and Execution. Harvard University Press. 2005, p. 171.

424 KLEIN, Benjamin; WRIGHT, Joshua. The Economics of Slotting Contracts. Journal of Law and Economics, Vol. 50, No. 3 (August 2007), p. 421. p. 1. No mesmo sentido, ver WRIGHT: “...unlike retailers in the economics literature, which exist only to reduce the search costs and supply consumer with their desired products, it is more realistic to assume that actual retailers have some discretion over product mix and shelf space allocation decisions that influence consumer purchasing behavior." WRIGHT, Joshua. Slotting Contracts and Consumer Welfare. In: Antitrust Law Journal, v. 74, 2007, p. 448.

${ }^{425}$ Conforme Relatório FTC 2001, p. 32: "These arrangements can lock up such a high proportion of space or preferential space, at so many outlets, that rivals' costs are substantially raised."

${ }^{426}$ WRIGHT, Joshua. Slotting Contracts and Consumer Welfare. In: Antitrust Law Journal, v. 74, 2007, p. 443. 
Ainda no âmbito da concorrência pela distribuição e por espaços em prateleira, merecem referência os sistemas de "administração por categoria" (category management), comuns no varejo alimentar dos Estados Unidos. Em linhas gerais, estes sistemas transferem o controle da administração do espaço de prateleiras com relação a uma determinada categoria de produtos dos estabelecimentos varejistas para algum fornecedor, que será o administrador desta categoria.

Os arranjos têm formatos variados e seus efeitos concorrenciais são ambíguos e ainda não totalmente compreendidos pela literatura e jurisprudência antitruste. ${ }^{427}$ Cada categoria passa a ser administrada como se fosse um negócio específico em separado e as várias atividades relativas a cada negócio/categoria (e.g. localização em prateleiras, promoções e reposições) são administradas em conjunto, com o objetivo de permitir uma coordenação mais eficiente. As decisões acerca de seleção de produtos, localização, exposição, promoção e preços são feitas com base em cada categoria, por um "administrador" (geralmente um fornecedor), com o objetivo de maximizar o lucro da categoria como um todo.

A amplitude das funções do fornecedor que administra a categoria varia conforme o arranjo com os varejistas, mas pode envolver desde o simples aconselhamento até a administração integral da categoria nos pontos de venda. A administração da categoria por parte do fornecedor pode incluir a recomendação de como e quais produtos devem ser $\operatorname{expostos}^{428}$ e engloba não somente os seus próprios produtos, como também os de outros fornecedores (concorrentes) dentro da mesma categoria. Em linhas gerais, recomendações acerca da exposição dos produtos são feitas por um fornecedor e, em contrapartida, os estabelecimentos varejistas recebem benefícios, como descontos nos preços do produto daquele fornecedor.

\footnotetext{
427 "The concept of category management covers a broad range of commercial relationships and practices, and asking whether it is good or bad is therefore like asking the blind men in the parable whether the elephant is a tree or a snake: it depends on which part of the elephant they are touching." GLAZER, Kenneth; HENRY, Brian R.; JACOBSON, Jonathan. Antitrust Implications of Category Management: Resolving the Horizontal/Vertical Characterization Debate. In: The Antitrust Source, July 2004, p. 1.

428 "Retail category management is a process whereby a supplier manages product groups on a store-by-store basis to help retailers meet customer demand, including advising how, and which, products should be displayed." AMERICAN BAR ASSOCIATION. Section of Antitrust Law. Antitrust Law and Economics of Product Distribution. American Bar Association, 2006, p. 292.
} 
Os benefícios associados aos sistemas de administração por categoria seriam, entre outros, o de reduzir os custos dos varejistas, ao transferir parte dos custos de organização da categoria do varejista para o fornecedor. Os sistemas forneceriam ao varejista melhor acesso à informação e, ainda, ajudariam o varejista a gerar mais vendas e obter mais lucros pelo espaço dedicado à categoria. ${ }^{429}$ Por fim, os sistemas de administração por categoria introduzem uma nova dimensão de concorrência entre os fornecedores, qual seja, a concorrência por ser o administrador da categoria. ${ }^{430}$

Os sistemas de administração por categoria, no entanto, trazem questões complexas e uma série de preocupações concorrenciais, entre elas, a possibilidade de que um fornecedor tenha informações acerca de planos promocionais de seus rivais, a facilitação de ações coordenadas entre fornecedores, a facilitação de ações coordenadas entre varejistas (quando, por exemplo, varejistas tiverem um mesmo administrador) e a possibilidade de exclusão ou criação de dificuldades a fornecedores rivais. ${ }^{431}$

Novamente, a principal preocupação concorrencial, decorrente dos sistemas de administração por categoria, refere-se à possibilidade de exclusão de pequenos fornecedores e aumento de poder de mercado do fornecedor que administra a categoria nos pontos de venda. ${ }^{432} \mathrm{~A}$ transferência da administração de uma categoria a um fornecedor abriria a possibilidade de manipulação da categoria, de forma a reduzir o espaço de fornecedores rivais. ${ }^{433}$ Em especial, estas práticas também podem ter efeitos semelhantes aos da exclusividade, pois podem também conduzir a uma situação de obstrução de "espaço de prateleira" para fornecedores rivais.

\footnotetext{
${ }^{429}$ STEINER relata que estudos acerca da utilização dos sistemas em alguns países europeus teriam demonstrado resultados expressivos de redução de custos na aplicação destes sistemas a produtos como margarina, detergentes e outros, bem como maior eficiência de sistemas de entrega de produtos. STEINER, Robert. Category Management: A Pervasive, New Vertical/Horizontal Format. In: Antitrust. Spring 2001, p. 78.

${ }^{430}$ GLAZER, Kenneth; HENRY, Brian R.; JACOBSON, Jonathan. Antitrust Implications of Category Management: Resolving the Horizontal/Vertical Characterization Debate. In: The Antitrust Source, July 2004, p. 2.

${ }^{431}$ Relatório FTC 2001, p. 49-50.

${ }^{432}$ STEINER, Robert. Category Management: A Pervasive, New Vertical/Horizontal Format. In: Antitrust, Spring 2001, p. 77 a 81.

433 "Category management simultaneously provides the opportunity for major cost savings in the distribution of consumer goods and a considerable potential for various sorts of antitrust mischief." STEINER, Robert. Category Management: A Pervasive, New Vertical/Horizontal Format. In: Antitrust, Spring 2001, p. 77.
} 


\subsection{Jurisprudência administrativa brasileira relativa a práticas de distribuição menos} tradicionais

A jurisprudência administrativa brasileira traz alguns exemplos de casos de abuso de posição dominante que envolvem estratégias menos tradicionais de distribuição.

Um caso paradigmático da jurisprudência administrativa brasileira envolveu o processo administrativo iniciado a partir de representação feita pela empresa Primo Schincariol Ind. Cervejas e Refrigerantes (Schincariol), em que foi representada a empresa Companhia de Bebidas das Américas - AMBEV (Ambev), julgado pelo CADE em $2009 .^{434}$

Conforme fatos do caso, a Schincariol apresentou representação à SDE, na qual alegou que a AMBEV teria adotado diversas práticas comerciais com pontos de venda, por meio das quais teria induzido os pontos de venda a comercializar com exclusividade cervejas de sua marca.

Em linhas gerais, o "Programa Tô Contigo" envolvia programa de relacionamento entre a AMBEV e pontos de venda, tais como bares e restaurantes, de acordo com o qual os pontos de venda acumulariam pontos a partir da quantidade de caixas de cerveja da marca AMBEV adquiridas; os pontos acumulados eram, então, trocados por prêmios, que, na prática, equivaleriam a descontos.

Ao examinar o caso, o conselheiro relator do caso, inicialmente, reconheceu que a AMBEV detinha posição dominante no mercado nacional de fornecimento de cervejas (aproximadamente 70\%) e passou à análise das provas coletadas e das acusações.

O conselheiro relator considerou que, do ponto de vista formal, o programa não traria riscos à concorrência, uma vez que, entre outros aspectos: o programa não induziria a uma situação de exclusividade, os descontos eram lineares, o programa tinha regras transparentes, o programa não era discriminatório e o preço praticado não configuraria prática de preços predatórios. ${ }^{435}$

\footnotetext{
${ }^{434}$ Processo Administrativo no 08012.003805/2004-10, decidido pelo CADE em 22 de julho de 2009. Conselheiro Relator: Fernando de Magalhães Furlan. Os fatos são relatados de acordo com informações constantes dos autos públicos, acessíveis em www.cade.gov.br.

${ }^{435}$ Conforme páginas 4933 e 4934 dos autos públicos.
} 
O conselheiro relator, no entanto, passou a analisar os requisitos "não formais" do "Programa Tô Contigo" a partir das provas produzidas nos autos. Ao examinar tais requisitos, o conselheiro considerou, em linha com o parecer da SDE, que a percepção de grande parte dos pontos de venda seria a de que o programa embutia a contrapartida de que os pontos de venda concentrassem suas compras de cerveja exclusivamente em produtos da marca AMBEV. Assim, havia uma percepção, por parte dos pontos de venda, de que, para participar do programa, seria necessário que eles deixassem de adquirir cervejas de marcas concorrentes ou que, pelo menos, o percentual adquirido de marcas concorrentes fosse reduzido ou limitado. Em síntese, o relator considerou que havia diversas evidências de que o programa embutia obrigações aos pontos de venda, ainda que estas não constassem dos documentos que formalizavam o programa.

Com base na análise das provas coletadas, ainda, o conselheiro relator considerou que os representantes da AMBEV fariam monitoramentos constantes nos pontos de venda, acerca do cumprimento do programa e, ainda, que haveria "retaliações implícitas" por parte da AMBEV, no caso de inadimplemento com as regras do programa, notadamente com a ameaça de desligamento dos pontos de venda do programa.

Ainda, de acordo com a constatação do relator, haveria exigência, por parte da AMBEV, de volume de estoque mínimo de $90 \%$ de cervejas de sua marca nos pontos de venda que participavam do programa. Observou, também, que as regras de premiação deixam de ser lineares em relação ao volume de compras dos pontos de venda e que, na prática, as regras do programa não seriam transparentes o suficiente para os pontos de venda; como consequência da falta de transparência, os pontos de venda tenderiam a cumprir com obrigações de exclusividade (ainda que parcial), para não correrem o risco de perder o direito a participar do programa - e, portanto, perder os benefícios do programa.

Em resumo, apesar de considerar que formalmente o programa não seria anticoncorrencial, a sua mecânica de execução, na prática, era outra. O relator concluiu, ainda, que não existiam eficiências econômicas capazes de justificar o "Programa Tô Contigo". Por fim, o relator concluiu que "os benefícios a longo prazo do programa não se resumem a um aumento da quantidade de cerveja vendida, mas também criam dificuldades 
ao acesso das empresas concorrentes aos canais de distribuição; no caso, aos varejistas, que se situam entre as empresas fabricantes de cervejas e os consumidores finais."

Vale notar que, durante a instrução, diversos pareceres foram apresentados pela representada, entre eles, pareceres de renomados doutrinadores brasileiros e estrangeiros, bem como de escritórios de advocacia estrangeiros, que examinavam se o "Programa Tô Contigo" seria lícito de acordo com a legislação antitruste dos Estados Unidos e com a legislação concorrencial da comunidade européia. Os pareceres dos escritórios e pareceristas estrangeiros examinaram o programa sob o ponto de vista formal e consideraram que, de acordo com as características do programa, ele seria lícito de acordo com as normas antitruste dos Estados Unidos e com as normas concorrenciais da comunidade europeia.

Outro caso da jurisprudência administrativa brasileira que merece menção refere-se aos casos envolvendo os acordos de exclusividade de merchandising e de comercialização no mercado de cigarros. Em 1998, a Philip Morris apresentou representação às autoridades antitruste contra a Souza Cruz, alegando que os acordos firmados entre a Souza Cruz e determinadas cadeias atacadistas e varejistas continham cláusulas combinadas de exclusividade de merchandising e de vendas, que teriam o efeito de fechar o mercado varejista e atacadista a fornecedores rivais. A representada (Souza Cruz) firmou um Termo de Compromisso de Cessação (TCC) com o CADE, por meio do qual se comprometeu, entre vários outros aspectos, a não realizar contratos que versassem sobre exclusividade de vendas (com algumas exceções) e a não impor obstáculos para que estabelecimentos varejistas comercializassem ou expusessem marcas de fabricantes concorrentes, pelo período estabelecido no TCC.

A Philip Morris apresentou diversas manifestações por meio das quais alegou que a Souza Cruz teria descumprido o TCC. Entre outros aspectos, a Philip Morris argumentava que o TCC teria sido descumprido pela Souza Cruz, uma vez que esta teria não somente firmado acordos de exclusividade de comercialização com alguns estabelecimentos, como também teria firmado acordos de exclusividade de merchandising e de exclusividade de

\footnotetext{
${ }^{436}$ Conforme p. 4954 dos autos públicos.
} 
exposição, que conduziriam à exclusividade de vendas junto aos estabelecimentos varejistas.

Com relação aos acordos de exclusividade de merchandising e de exposição, a Souza Cruz alegou que tais práticas não eram objeto do TCC e, ainda, que também seriam adotadas por outras concorrentes no mercado de cigarros, inclusive pela própria Philip Morris. No contexto da discussão acerca do descumprimento do TCC, o ConselheiroRelator encaminhou ofício à SDE, para que ela averiguasse a prática de exclusividade de merchandising e de exposição no mercado de cigarros e, como resultado, a SDE instaurou um novo processo administrativo, desta vez em face da Souza Cruz e da Philip Morris, para investigar a prática de exclusividade de merchandising. Até o momento de conclusão deste trabalho, o caso ainda estava sendo examinado pelas autoridades de defesa da concorrência brasileiras. $^{437}$

\section{ESTRATÉGIAS DE DISTRIBUiÇÃO TENTENDES À EXCLUSÃo E O DIREITO BRASILEIRO DA CONCORRÊNCIA}

Como já tratamos, nos termos da Lei 8.884/94 - e, também, da Lei 12.529/2011 -, a ilicitude das condutas comerciais adotadas pelos agentes econômicos é caracterizada a partir de seus efeitos. ${ }^{438} \mathrm{Em}$ outras palavras, um dos principais aspectos relativo às infrações à ordem econômica e, portanto, à disciplina de repressão ao abuso de posição dominante, refere-se ao fato de que a forma do ato não é relevante para que se avalie a sua licitude.

Consideramos a abordagem da legislação brasileira apropriada, uma vez que, caso se optasse por uma classificação e categorização formal dos atos que configurariam infração à ordem econômica, os agentes econômicos poderiam facilmente formatar negócios jurídicos potencialmente prejudiciais à concorrência de maneira que estes não se enquadrassem formalmente na classificação proposta. A abordagem, assim, confere a flexibilidade necessária à dinâmica das relações econômicas, como já tratamos diversas vezes ao longo deste trabalho.

\footnotetext{
${ }^{437}$ Processo Administrativo $\mathrm{n}^{\circ}$ 08012.003921/2005-10. Representante: Conselho Administrativo de Defesa Econômica; Representadas: Souza Cruz S/A e Philip Morris Brasil Indústria e Comércio Ltda.

${ }^{438}$ FORGIONI, Paula A. Os Fundamentos do Antitruste. $2^{\mathrm{a}}$ ed., São Paulo: Revista dos Tribunais, 2005 , p. 146-147.
} 
Em nossa opinião, a abordagem da legislação brasileira, ao evitar categorizações formais, confere maior possibilidade de adequação e adaptação às diferentes formas que estratégias de distribuição (tradicionais ou não) podem tomar e, ainda, evita a "guerra de classificações" que hoje parece ocorrer nos Estados Unidos no que tange determinados tipos de práticas de distribuição (conforme discutido nos itens anteriores).

A dificuldade da abordagem da legislação brasileira, por outro lado, é a incerteza e a falta de previsibilidade quanto ao que configura um ilícito de exclusão ou quando uma prática de distribuição, potencialmente pro-competitiva (tais como promoções, investimentos em distribuidores em troca de exclusividade, descontos e outras), pode configurar uma conduta ilícita, se adotada por um fornecedor em posição dominante.

Infelizmente, a jurisprudência administrativa brasileira sobre abuso de posição dominante e práticas de distribuição ainda não está desenvolvida a ponto de oferecer indicativos suficientes para uma orientação aos agentes econômicos dominantes acerca de quais comportamentos eles podem ou não adotar. Os casos em que as autoridades de defesa da concorrência tiveram a oportunidade de realizar uma análise mais profunda acerca dos efeitos e eficiências das práticas ainda são poucos.

Ao longo da preparação deste trabalho, buscamos identificar todas as decisões administrativas proferidas pelo CADE no que diz respeito às estratégias tradicionais de distribuição tendentes à exclusão, nos últimos 5 (cinco) anos, a saber: as práticas de preços predatórios, práticas de exclusividade, recusas unilaterais de contratar e vendas casadas. O objetivo desta pesquisa foi identificar como a ideia de exclusão teria sido tratada nos casos decididos pelo CADE nos últimos anos. A opção pela limitação da pesquisa aos últimos 5 (cinco) justifica-se em razão de buscarmos identificar tendências mais recentes das decisões proferidas pelas autoridades da concorrência brasileiras. É necessário esclarecer, contudo, que não deixamos de examinar casos mais antigos, quando relevantes ao objeto de estudo.

O que se pode observar a partir do exame da jurisprudência administrativa é que diversos casos foram iniciados com base em representações que versavam sobre questões de ordem privada e, portanto, não afetas à disciplina da concorrência. Este aspecto reflete, em nossa opinião, um desconhecimento por parte dos agentes econômicos acerca do âmbito de aplicação das normas de concorrência. De certa forma, este desconhecimento é natural, 
devido ao ainda relativo isolamento da disciplina da concorrência e ao fato de ainda tratarse de matéria para "especialistas", como discutimos na introdução a este trabalho. O resultado destas investigações levou ao arquivamento de grande parte das averiguações preliminares e processos administrativos instaurados.

Além disso, muitas vezes, as representações foram feitas com base em alegações envolvendo mais de um tipo de conduta e diferentes incisos do artigo 21 da Lei 8.884/94. Em alguns casos, este aspecto parece ser explicável devido à ausência de conhecimento por parte dos representantes acerca de como "classificar" a conduta que estava sendo questionada - e não devido ao fato de que determinada conduta pudesse estar enquadrada em mais de um inciso do artigo 21. Este "problema", contudo, é sanável, pois, como dito, a configuração da prática como ilícito não depende da forma como ela é apresentada, mas de como ela opera na realidade e dos efeitos que ela pode ter na concorrência. Nosso sistema permite que se busque identificar a essência da prática que está sendo questionada e examinar seus efeitos, independente da forma como ela foi inicialmente apresentada pelos representantes, respeitados, por óbvio, os princípios relativos ao devido processo legal e da ampla defesa das partes cujas condutas são questionadas.

Vale notar que os casos mais relevantes relativos a práticas de distribuição tendentes à exclusão decididos pelo CADE durante o período pesquisado referiram-se a casos envolvendo as condutas de exclusividade e/ou recusa unilateral de contratar. Afirmamos que estes casos são relevantes no contexto do nosso estudo, em razão do maior aprofundamento encontrado nas discussões jurídicas e econômicas empreendidas ao longo dos processos administrativos.

Nosso argumento, em síntese, é que o desenho legislativo brasileiro é apto a enfrentar dos desafios apresentados pela evolução das práticas de distribuição tendentes à exclusão. A jurisprudência administrativa, contudo, ainda não oferece o grau de certeza desejável. 


\section{CAPITULO V - CONCLUSÃO}

\section{DIAGNÓSTICO}

Como tivemos a oportunidade de referir no início deste trabalho, a disciplina da concorrência no Brasil ainda se encontra em estado de relativo isolamento, sendo ainda matéria para "especialistas", não obstante os mais de 15 (quinze) anos de vigência da Lei 8.884/94, prestes a ser revogada pela Lei 12.529/2011.

Em nossa opinião, este relativo isolamento da disciplina resulta de uma combinação de fatores. O principal deles refere-se ao fato de que a implementação das normas de disciplina da concorrência no Brasil ainda é feita precipuamente de forma "centralizada", ou seja, pelas autoridades que compõem o Sistema Brasileiro de Defesa da Concorrência (SBDC), no contexto de processos administrativos ou atos de concentração iniciados por estas autoridades ou levados ao seu conhecimento por terceiros. Como já apontado, contudo, as possibilidades legais de aplicação das normas de disciplina da concorrência não estão limitadas à atuação dos órgãos de defesa da concorrência. A disciplina da concorrência pode ser aplicada diretamente por agentes econômicos privados e por meio de instrumentos processuais de tutela coletiva. O cenário atual, no entanto, é de poucas iniciativas de implementação por agentes econômicos privados diretamente perante os tribunais e de um irrisório número de ações propostas no âmbito da tutela coletiva.

Vale observar, ainda, que o foco de atuação das autoridades que compõem o Sistema Brasileiro de Defesa da Concorrência (SBDC) tem se concentrado, pelo menos nos últimos 10 (dez) anos, no combate aos cartéis, com reconhecido desenvolvimento dos mecanismos de articulação e de investigação que objetivam o combate a este tipo de conduta. Não discutimos aqui o acerto ou erro desta opção das autoridades em priorizar o combate aos cartéis. Trata-se somente de reconhecer uma situação de fato, que equivale a dizer que o ilícito de abuso de posição dominante não esteve, pelo menos na última década, no topo de prioridades do Sistema Brasileiro de Defesa da Concorrência (SBDC).

Os casos relacionados a abuso de posição dominante que foram iniciados pelas autoridades brasileiras nos últimos anos foram, em sua imensa maioria, provocados a partir de representações de terceiros (geralmente concorrentes dos agentes dominantes cuja conduta se questiona), e não iniciados de ofício pelas autoridades. Por um lado, esta 
situação é natural, pois que os agentes econômicos que se sentem diretamente prejudicados por condutas de agentes econômicos em posição dominante terão maior conhecimento acerca das práticas de distribuição que os prejudicam no dia-a-dia (e da forma pela qual os prejudicam), do que as autoridades de defesa da concorrência.

Ao longo do trabalho, observamos alguns fatores que dificultam a adequada compreensão do abuso de posição dominante e de práticas de distribuição, o que coloca esta área da disciplina da concorrência em situação de ainda maior isolamento. É de se notar que práticas de distribuição adotadas por agentes econômicos em posição dominante têm relevância, por exemplo, para a disciplina dos contratos, e o fato de o seu tratamento ser ainda "centralizado" nas discussões travadas no âmbito do SBDC é um exemplo do desconhecimento da disciplina da concorrência em um cenário mais amplo e de suas possíveis repercussões em outras esferas.

Os principais aspectos observados ao longo do trabalho são sumarizados a seguir.

As normas brasileiras relativas ao ilícito de posição dominante (desenho legislativo) são abertas e permeáveis a fatores "externos" ao desenho legislativo. Apesar de esta abordagem oferecer flexibilidade adequada à análise das atividades econômicas, dinâmicas por natureza, a abertura das normas oferece um grau de incerteza e de falta de previsibilidade maior do que em outras áreas da disciplina da concorrência.

As práticas de distribuição tendentes à exclusão que podem ser adotadas por fornecedores em posição dominante são muito variadas e estão em constante evolução. O quadro acerca da licitude destas práticas, quando adotadas por agentes dominantes, parece incerto - tanto no direito estrangeiro, quanto no direito brasileiro -, tendo em vista as dificuldades intrínsecas à análise destas condutas. Em particular, no direito norte-americano, como vimos, existe uma discussão acerca de como "classificar" algumas das estratégias menos tradicionais e qual o padrão de análise a ser aplicado na sua avaliação.

De forma geral, há um significativo grau de incerteza quanto aos padrões a serem aplicados pela teoria econômica com relação às estratégias de distribuição tendentes à exclusão adotadas por fornecedores em posição dominante. A teoria econômica encontra-se em evolução e, mesmo em jurisdições com maior tradição antitruste (Estados Unidos e 
Europa), há controvérsia sobre qual a melhor forma de avaliá-las do ponto de vista concorrencial.

O desenho legislativo brasileiro é apto a enfrentar dos desafios apresentados pela evolução das práticas de distribuição tendentes à exclusão. A jurisprudência administrativa brasileira existente, contudo, não oferece ainda um corpo consistente de decisões que possam guiar os agentes econômicos em posição dominante quanto a quais comportamentos relacionados às suas opções de distribuição estão dentro ou fora do âmbito de licitude, sob a perspectiva do direito da concorrência.

\section{PERSPECTIVAS}

A partir do diagnóstico acima, vale refletir acerca das perspectivas futuras para o tratamento de abuso posição dominante envolvendo práticas de distribuição tendentes à exclusão. Nesse contexto, é necessário levar em consideração a expectativa da entrada em vigor da Lei 12.529/2011.

Como já dito, no que diz respeito ao ilícito de abuso de posição dominante, a Lei 12.529/2011 não trouxe modificações significativas. As principais alterações trazidas pela lei envolvem: o controle prévio de operações de concentração econômica (atos de concentração); a mudança dos critérios de notificação dos atos de concentração (inclusive com o estabelecimento de patamares mais baixos de faturamento), o que tende a reduzir o número de atos de concentração que deverão ser submetidos à análise das autoridades; e a modificação da estrutura do Sistema Brasileiro de Defesa da Concorrência (modificação do desenho institucional). Além destas modificações, dois outros pontos merecem menção: a Lei 12.529/2011 prevê um aumento do quadro de servidores, o que, de acordo com o discurso formal das autoridades, deve tornar o sistema mais ágil; e o mandato dos conselheiros do Tribunal Administrativo (que exercerá funções semelhantes às do atual CADE) passará a ser de 4 (quatro) anos - e não mais de 2 (dois) anos, renováveis por outros 2 (dois) anos.

Uma visão otimista destas mudanças traz a expectativa de que, em razão da esperada redução do número de operações de concentração econômica que serão notificadas, as autoridades terão mais recursos para examinar questões relacionadas às condutas anticompetitivas, pelo menos a médio ou longo prazo. Ainda que o principal foco 
das autoridades continue a ser, no âmbito das condutas, o combate aos cartéis, é possível aventar a possibilidade de que maior atenção seja dada aos ilícitos relativos aos abusos de posição dominante. Além disto, o mandato mais longo para os conselheiros pode trazer o benefício de uma maior consistência nas decisões a serem proferidas nestes casos. Isto porque o mandato de 2 (dois) anos trazia dificuldades ao estabelecimento de uma "jurisprudencial institucional". Por maiores que tenham sido os esforços nos últimos anos para se estabelecer uma jurisprudência institucional consistente com relação a uma série de aspectos da disciplina da concorrência, o mandato de 2 (dois) anos era um elemento que ameaçava rupturas constantes em entendimentos consolidados ou quase consolidados. Por fim, o maior número de servidores pode também contribuir para que as autoridades administrativas tenham a possibilidade de dedicar mais recursos para às condutas relacionadas aos abusos de posição dominante.

Seguindo esta linha otimista acerca das mudanças a serem trazidas com o advento da nova lei, podemos ter a expectativa, portanto, de que um maior número de casos envolvendo abuso de posição dominante e estratégias de distribuição sejam levados ao conhecimento das autoridades concorrenciais, criando, com isto, a possibilidade de que, em alguns anos, o número de casos decididos pelas autoridades possa oferecer diretrizes mais claras acerca do tema.

Um outro aspecto que merece menção quanto a perspectivas refere-se à possível e gradual "descentralização" da aplicação das normas de defesa da concorrência. A maior divulgação da disciplina da concorrência (ainda que por meio da divulgação de decisões administrativas), pode gradualmente levar os agentes econômicos a buscar outras formas de implementação das normas, ou seja, por meio de ações judiciais diretamente propostas perante os tribunais. Ações envolvendo potenciais abusos de posição dominante e práticas de distribuição são objetos possíveis de ações judiciais, não somente no contexto de ações ajuizadas por agentes econômicos prejudicados por tais práticas, como também com relação a argumentos de defesa relacionados a ações judiciais envolvendo questões de distribuição. Com relação a este último aspecto, vale notar que, argumentos concorrenciais podem ser levantados - e já o foram - em disputas judiciais envolvendo relações de distribuição. Com o maior conhecimento por parte dos agentes econômicos acerca das práticas de distribuição potencialmente anticoncorrenciais, tais argumentos podem aparecer com maior frequência 
em discussões judiciais. Finalmente, também é possível que discussões acerca de abuso de posição dominante e práticas de distribuição sejam trazidas no contexto de ações coletivas, o que, hoje, ainda não é uma realidade. As ações civis públicas hoje existentes relacionadas a aspectos de direito da concorrência focam-se em discussões envolvendo, em sua maioria, casos de cartel.

Os possíveis benefícios de uma "descentralização" da implementação das normas de direito da concorrência referem-se à possibilidade de um arrefecimento do isolamento da disciplina da concorrência e, como consequência, uma discussão mais ampla acerca de vários de seus aspectos, inclusive, os relativos aos abusos de posição dominante e as relações de distribuição.

\section{CONCLUSÃO}

Como já dissemos, uma das principais tarefas de agentes econômicos fornecedores de bens e serviços refere-se às decisões acerca de como melhor escoar sua produção e colocar seus produtos/serviços no mercado, com o objetivo de aumentar suas vendas e, portanto, aumentar sua participação de mercado. A tarefa de estruturar um sistema de distribuição eficiente é, assim, fundamental para o sucesso comercial de fornecedores de bens e serviços.

Ao definir os seus sistemas de distribuição, fornecedores buscam constantemente melhorar suas estratégias comerciais e podem encontrar formas inovadoras e criativas de distribuir seus produtos de maneira ainda mais eficiente. Esta busca é não somente natural, como também desejável do ponto de vista da concorrência e, muitas vezes, beneficia os próprios fornecedores, seus intermediários e os consumidores finais de seus produtos/serviços.

O direito da concorrência deve, em princípio, ser favorável a posturas agressivas e inovadoras de fornecedores de bens e serviços, na medida em que estas acirram a competição, uma vez que fornecedores concorrentes buscarão também inovar seus sistemas de distribuição, bem como estabelecer descontos ou condições mais atrativos aos compradores, melhorar seus produtos e serviços, entre outros. Este acirramento da competição entre fornecedores concorrentes, no que tange aos seus sistemas de distribuição, tende a beneficiar os consumidores finais, que terão, em princípio, mais alternativas de 
produtos/serviços à sua disposição e diferentes vantagens oferecidas pelos fornecedores na busca de sua preferência.

Como vimos, no entanto, quando um fornecedor ocupa posição dominante em determinado mercado, suas estratégias de distribuição podem prejudicar a concorrência, uma vez que podem ter efeitos potenciais de aumentar custos de seus rivais (principalmente relacionados à distribuição) ou, até mesmo, excluir rivais do mercado. Ocorre que, um agente econômico, mesmo dominante, deve buscar concorrer de formar agressiva, por meio de menores preços e investimentos em inovação. A inovação, registre-se, não se limita à inovação em relação aos produtos ou serviços oferecidos, mas também pode e deve envolver formas inovadoras de distribuir e colocar seus produtos/serviços no mercado.

A dificuldade em conceituar os abusos de posição dominante tendentes à exclusão é amplamente reconhecida pela literatura antitruste. Quando estes abusos envolvem a adoção de práticas de distribuição tendentes à exclusão, contudo, as dificuldades em definir parâmetros de licitude são ainda maiores. Isto porque, não somente é difícil definir quando um comportamento tendente à exclusão é ilícito, como, também, muitas estratégias de distribuição têm justificativas comerciais legítimas e podem trazer benefícios de eficiência.

Nesse cenário, um elemento complicador refere-se ao fato de que as técnicas de distribuição tendem a se aperfeiçoar, tendem a evoluir, e novas estratégias de distribuição são desenvolvidas e adotadas por fornecedores. Diante da dificuldade já existente na análise de abusos de exclusão relacionados a práticas de distribuição tradicionais, o surgimento de "novas" estratégias de distribuição não facilita a tarefa da definição de sua licitude do ponto de vista concorrencial.

Ao longo deste trabalho, observamos que há enorme controvérsia no tratamento de abuso de posição dominante em casos de práticas de distribuição tendentes à exclusão e que, mesmo em jurisdições com maior tradição antitruste, o tema é objeto de muita incerteza.

Infelizmente, a falta de clareza quanto aos parâmetros de licitude destas práticas, quando adotadas por agentes econômicos detentores de posição dominante, tende a desencorajar que estes adotem condutas mais agressivas ao estabelecer seus sistemas de distribuição. Não havendo clareza acerca das linhas que separam condutas lícitas de ilícitas, pode haver uma falta de incentivo a condutas agressivas por parte de agentes dominantes, 
que podem optar por práticas comerciais mais conservadoras; como resultado, pode haver um arrefecimento da dinâmica concorrencial, o que é indesejável sob qualquer perspectiva.

O tema objeto deste estudo, portanto, envolve um dilema e uma questão que permanece aberta, qual seja, definir em que circunstâncias práticas de distribuição tendentes à exclusão, quando adotadas por fornecedores em posição dominante, devem ser consideradas ilícitas do ponto de vista concorrencial.

Consideramos que a melhor forma de enfrentar esta questão é, inicialmente, buscar uma maior compreensão das estratégias ligadas à distribuição e suas motivações comerciais. Cada mercado, produto ou serviço tem suas peculiaridades no que tange ao melhor formato de distribuição e, portanto, a compreensão do mercado e da natureza dos serviços e produtos distribuídos parece essencial ao correto entendimento das motivações comerciais.

Nossa conclusão, por fim, é que a análise dos casos de alegação de abusos de posição dominante envolvendo práticas de distribuição tendentes à exclusão deve ser feita com muito cuidado, para evitar criar, por um lado, situações de em que agentes econômicos (ainda que dominantes) sejam penalizados por comportamentos possivelmente prócompetitivos (e passem a adotar posturas muito cautelosas e conservadoras) e, por outro, não deixar de reprimir condutas que prejudiquem a concorrência. Em síntese, o tratamento das práticas de distribuição tendentes à exclusão deve encontrar um equilíbrio entre, de um lado, a repressão adequada dos abusos de posição dominante envolvendo relações de distribuição e, de outro, a preservação do incentivo para que fornecedores adotem formas eficientes, inovadoras e concorrenciais de estruturar seus sistemas de distribuição. Este equilíbrio é a chave para tentar responder à indagação que propusemos neste estudo. 


\section{BIBLIOGRAFIA:}

AMERICAN BAR ASSOCIATION, SECTION OF ANTITRUST LAW. Monopolization and Dominance Handbook, American Bar Association, 2011.

AMERICAN BAR ASSOCIATION. Section of Antitrust Law. Antitrust Law Developments, ABA Book Publishing, $6^{\text {th }}$ Edition, 2007.

AMERICAN BAR ASSOCIATION. Section of Antitrust Law. Antitrust Law and Economics of Product Distribution. American Bar Association, 2006.

AREEDA, Phillip E.; HOVENKAMP, Herbert. Antitrust Law: An Analysis of Antitrust Principles and Their Applications. Aspen, $2^{\text {nd }}$ edition, 2002.

AKMAN, Pinar. Searching for the Long-Lost Soul of Article 82 EC. CCP Working Paper 07-5, dezembro de 2007, acessível em http://www.uea.ac.uk/polopoly_fs/1.104585!ccp07-5.pdf, acesso em novembro de 2011.

BAKER, Jonathan B. Preserving a Political Bargain: The Political Economy of the NonInterventionist Challenge to Monopolization Enforcement. In: Antitrust Law Journal, v. 76, Issue 3, 2010, p. 605-652.

BAKER, Jonathan B. A Preface to Post-Chicago Antitrust. In: VAN DEN BERGH, Roger et al. (eds.). Post-Chicago Developments in Antitrust Analysis, Edward Elgar, 2002.

BAKER, Jonathan B. Predatory Pricing after Brooke Group: An Economic Perspective. In: Antitrust Law Journal, v. 62, 1994, p. 585-603.

BAKER, Jonathan B. Recent Developments in Economics that Challenge Chicago Views. In: Antitrust law Journal, v. 58, 1989-1990, p. 645-655.

BISHOP, Simon; WALKER, Mike. The Economics of EC Competition Law: Concepts, Applications and Measurement. London, Sweet \& Maxwell, 2002.

BORK, Robert H. The Antitrust Paradox. A Policy at War with Itself. The Free Press, 1993. 
BORK, Robert H. Legislative Intent and the Policy of the Sherman Act. In: Journal of Law and Economics, v. 9, 1966.

BOWMAN, Ward S. Tying Arrangements and the Leverage Problem. In: The Yale Law Journal, v. 67, n. 1, November 1957, p. 19-36.

BRUNA, Sérgio Varella. O poder econômico e a conceituação do abuso em seu exercício. São Paulo: Editora Revista dos Tribunais, 1997.

BUCCI, Maria Paula Dallari. O Conceito de Política Pública em Direito. In: BUCCI, Maria Paula Dallari (org.) Políticas Públicas. Reflexões sobre o Conceito Jurídico. Editora Saraiva, 2006, p. 1-47.

CAMPBELL, Neil A.; ROWLEY, J. William. The Internationalization of Unilateral Conduct Laws - Conflict, Comity, Cooperation and/or Convergence? In: Antitrust Law Journal, v. 75, n. 2, 2008, p. 267-351.

CAPPELlETTI, Mauro; GARTH, Bryant. Acesso à Justiça. Tradução de Ellen Gracie Northfleet. Porto Alegre: Sergio Antonio Fabris, 1988.

CARLTON, Dennis W. A General Analysis of Exclusionary Conduct and Refusal to Deal Why Aspen and Kodak are Misguided. In: Antitrust Law Journal, v. 68, 2000-2001, p. 659-683.

CARVAlHO, Livia C. L. Gândara. Responsabilidade Civil Concorrencial: a busca da efetiva reparação de danos. Trabalho de Conclusão de Curso apresentado à Escola de Direito FGV, em 16 de novembro de 2011.

COASE, Ronald H. The Nature of the Firm. In: Economica, 1937, 4: 386-405.

COLLINS, Hugh. Regulating Contracts. Oxford University Press, 1999.

COMISSÃO EUROPÉIA. Comunicação da Comissão — Orientação sobre as prioridades da Comissão na aplicação do artigo 82.o do Tratado CE a comportamentos de exclusão abusivos por parte de empresas em posição dominante (2009/C 45/02) 
24.2.2009. Jornal Oficial da União Européia, disponível em http://eurlex.europa.eu/LexUriServ/LexUriServ.do?uri=OJ:C:2009:045:0007:0020:PT:PDF, acesso em novembro de 2011.

CORRÊA, Mariana Villela. Exclusividade e Direito da Concorrência. Dissertação de Mestrado apresentada ao Departamento de Direito Comercial, Universidade de São Paulo, Faculdade de Direito, São Paulo, 2008.

CUCINOTTA, Antonio; PARDOLESI, Roberto; VAN DEN BERGH, Roger (eds.) PostChicago Developments in Antitrust Law. New Horizons in Law and Economics Series, Edward Elgar, 2002.

DEVLIN, Alan; JACOBS, Michael. Microsoft's Five Fatal Flaws. In: Columbia Business Law Review, v. 2009, n. 1, p. 67-108, 2009.

ELHAUGE, Einer; GERADIN, Damien. Global Competition Law and Economics. Oxford and Portland: Hart Publishing, 2007.

ELHAUGE, Einer. Defining Better Monopolization Standards. In: Stanford Law Review, v. 56, Novembro de 2003, p. 253-344.

EVANS, David; PADILLA, Jorge. Designing Antitrust Rules for Assessing Unilateral Practices: A Neo-Chicago Approach. In: University of Chicago Law Review, v. 72 (1), 2005, p. 73-98.

FEDERAL TRADE COMMISSION. Report on the Federal Trade Commission Workshop on Slotting Allowances and Other Marketing Practices in the Grocery Industry, a Report by Federal Trade Commission Staff, February 2001.

FERRARESE, Maria Rosaria, Diritto e mercato, Torino, G. Giappiachelli Editore, 1992.

FERRAZ, Sergio; DALlARI, Adilson Abreu. Processo Administrativo, São Paulo, Malheiros, $2^{\mathrm{a}}$ edição, 2007. 
FERRAZ JUNIOR, Tércio Sampaio. Concorrência como tema constitucional. In: Revista do IBRAC, São Paulo, v. 16, n.1, 2009, p. 170-186.

FORGIONI, Paula A. A evolução do direito comercial brasileiro: da mercancia ao mercado. São Paulo, Editora Revista dos Tribunais, 2009.

FORGIONI, Paula A. Direito Concorrencial e Restrições Verticais. São Paulo: Editora Revista dos Tribunais, 2007.

FORGIONI, Paula A. Contrato de Distribuição. $1^{\mathrm{a}}$ ed. São Paulo: Revista dos Tribunais, 2005.

FORGIONI, Paula A. Os Fundamentos do Antitruste. $2^{\mathrm{a}}$ ed. São Paulo: Revista dos Tribunais, 2005.

FOX, Eleanor M. The Efficiency Paradox. In: PITOFSKY, Robert (Ed.). How the Chicago School Overshot the Mark. The Effect of Conservative Economic Analysis of U.S. Antitrust, Oxford University Press, 2008, p. 77-88.

FOX, Eleanor M. Monopolization, Abuse of Dominance, and the Indeterminancy of Economics: The U.S./E.U Divide. In: Utah Law Review, 2006, p. 725-740.

FOX, Eleanor M. Is There Life in Aspen After Trinko? The Silent Revolution of Section 2 of the Sherman Act. In: Antitrust Law Review, v. 73, n.1, 2005, p. 153-169.

FOX, Eleanor M. Abuse of dominance and monopolization: how to protect competition without protecting competitors. In: EUI-RSCA/EU Competition 2003.

FOX, Eleanor M. We Protect Competition, You Protect Competitors. In: World Competition, v. 26, n. 2, 2003, p. 1-8.

FOX, Eleanor M. What is Harm to Competition? Exclusionary Practices and Anticompetitive Effect. In: Antitrust Law Journal, v. 70, 2002, p. 371-411.

FOX, Eleanor M. The Battle for the Soul of Antitrust. In: California Law Review, v. 75, n. 3, Symposium: Anticipating Antitrust's Centennial, May 1987, pp. 917-923. 
FOX, Eleanor M. ; SUlliVAN, Lawrence A. Cases and Materials on Antitrust. American Casebook Series. West Publishing Co. , st. Paul, Minn., 1989.

FRANCESCHINI, José Ignácio Gonzaga, Legislação Brasileira Antitruste. São Paulo, 1986.

GAL, Michal S.; TOR, Avishalom; WALLER, Spencer Weber. Introduction: Expansion and Contraction in Monopolization Law. In: Antitrust Law Journal, v. 76, n. 3, 2010, p. 653-661.

GAVIL, Andrew I. Exclusionary Distribution Strategies by Dominant Firms: Striking a Better Balance. In: Antitrust Law Journal, V. 72, 2004, p. 3.

GAVIL, Andrew I; KOVACIC, William E.; BAKER, Jonathan B. Antitrust Law in Perspective: Cases, Concepts and Problems in Competition Policy. American Casebook Series, Thompson West, Second Edition, 2008.

GELlHORN, E.; KOVACIC, W. E.; CALKINS, S.. Antitrust Law and Economics in a Nutshell. 5th Edition. Thompson West, 2004.

GERBER, David J. Convergence in the Treatment of Dominant Firm Conduct: The United States, The European Union, and the Institutional Embeddedness of Economics. In: Antitrust Law Journal, v. 76, n. 3, 2010, p. 951-986.

GERBER, David J. Competition Law and the Institutional embeddedness of economics. In: DREXL, Josef; IDOT, Lawrence; MONÉGER, Joel. Economic Theory and Competition Law, Chelteham: Elgar, 2009, p. 20-43.

GERBER, David J. Law and Competition in Twentieth Century Europe. Protecting Prometheus. Oxford University Press, 2003.

GERBER, David J. Law and Competition in Twentieth Century Europe. Protecting Prometheus. Oxford University Press, 2003. 
GERBER, David. Constitutionalizing the Economy: German Neo-Liberalism, Competition Law and the "New" Europe. In: American Journal of Competition Law, v. 42, 1994.

GERBER, David J. Law and the Abuse of Economic Power in Europe. In: Tulane Law Review, v. 62, 1987-1988, p. 57-107.

GLAZER, Kenneth; HENRY, Brian R.; JACOBSON, Jonathan. Antitrust Implications of Category Management: Resolving the Horizontal/Vertical Characterization Debate. In: The Antitrust Source, July 2004.

GONÇALVES. Priscila Brolio. A obrigatoriedade de contratar no direito antitruste. Editora Singular, 2010.

GONÇALVES, Priscila Brólio. Fixação e Sugestão de Preços de Revenda em Contratos de Distribuição. São Paulo: Editora Singular, 2002.

GORMSEN, Linda L. The Conflict Between Economic Freedom and Consumer Welfare in the Modernization of Article 82 EC. In: European Competition Journal, v. 3, n. 2, December 2007, p. 329-344.

GRANITZ, Elizabeth; KLEIN, Benjamin. Monopolization by "Raising Rivals Costs": The Standard Oil Case. In: Journal of Law and Economics, v. 39, 1986.

GRAU, Eros R. A Ordem Econômica na Constituição de 1988, $11^{\mathrm{a}}$ ed., São Paulo: Malheiros, 2006.

GRINOVER, Ada Pellegrini. Significado Social, Político e Jurídico da tutela dos interesses difusos. In: Revista de Processo n. 97.

GRINOVER, Ada Pellegrini. O termo de ajustamento de conduta no âmbito da defesa da concorrência. In: Revista do IBRAC, v. 16-1, 2009.

HAWK, Barry E. Article 82 and Section 2: Abuse and Monopolization Conduct. In: Issues in Competition Law and Policy, Volume II, 2008, ABA Section of Antitrust Law, p. 871-893. 
HAWK, Barry E. United States, Common Market and International Antitrust: A Comparative Guide, $2^{\text {nd }}$ edition, Aspen Law \& Business, 1990.

HAYS, George A. Market Power in Antitrust. In: Antitrust Law Journal, v. 60, 1992, p. 807-827.

HOVENKAMP, Herbert. The Harvard and Chicago School and the Dominant Firm. In: PITOFSKY, Robert (Ed.). How the Chicago School Overshot the Mark. The Effect of Conservative Economic Analysis of U.S. Antitrust, Oxford University Press, 2008, p. 108-122.

HOVENKAMP, Herbert.. The Antitrust Standard for Unlawful Exclusionary Conduct. In: University of Iowa Legal Studies Research Papers, number 08-29, June, 2008, disponível em http://papers.ssrn.com/sol3/papers.cfm?abstract_id=1140346.

HOVENKAMP, Herbert. The Law of Exclusionary Pricing. In: Competition Policy International, v. 2, n. 1. Spring, 2006, p. 21-39.

HOVENKAMP, Herbert. Discounts and Exclusion. In: Utah Law Review, n. 3, 2006, p. 841-861.

HOVENKAMP, Herbert. The Antitrust Enterprise: principle and execution. Harvard University Press, Cambridge, Massachusetts; London, England, 2005.

HOVENKAMP, Herbert. Exclusion and the Sherman Act. In: University of Chicago Law Review, v. 72, 2005, p. 145.

HOVENKAMP, Herbert. Post-Chicago Antitrust: A Review and Critique. In: Columbia Business Law Review, 2001, p. 257-337.

HOVENKAMP, Herbert. Federal Antitrust Policy - The Law of Competition and its Practice, St. Paul, Minn., Second Edition, West Publishing Co., 1999.

HOVENKAMP, Herbert. Antitrust Policy After Chicago. In: Michigan Law Review, v. 84, 1986, p. 212-284. 
HOVENKAMP, Herbert; SUlLIVAN, E. Thomas. Antitrust Law, Policy and Procedure: Cases, Materials, Problems. $4^{\text {th }}$ edition. Lexis Law Publishing, 1999.

IRTI, Natalino. A ordem jurídica do mercado. In: Revista de Direito Mercantil, Industrial, Econômico e Financeiro, Vol. 145, Ano XLVI (nova Série), janeiro-março/2007, Malheiros Editores, p. 44-49.

IRTI, Natalino. Persona e Mercato. In: IRTI, Natalino. L'Ordine Giuridico del Mercato. Editori Laterza, 2001.

RTI, Natalino. L'Ordine Giuridico del Mercato, In: L'Ordine Giuridico del Mercato. Editori Laterza, 2001.

IRTI, Natalino. Introdução ao livro Il Dibattito Sull'Ordine Guirdico Del Mercato - Editori Laterza, 1999. Texto traduzido e fornecido pela Profa. Rachel Sztaijn.

JACOBS, Michael. An Essay on the Normative Foundations of Antitrust Economics. In: North Carolina Law Review, v. 74, 1995-1996, p. 228.

JACOBSON, Jonathan M. Exclusive Dealing, "Foreclosure", and Consumer Harm. In: Antitrust Law Journal, v. 70, n. 2, 2002, p. 311.

JACOBSON, Jonathan M.; SHER, Scott A. "No Economic Sense" Makes no Sense for Exclusive Dealing. In: Antitrust Law Journal, v. 73, n. 3, 2006, p. 779 - 801.

JAECKEL, Jeffrey A. Le Page's, Cascade Health Solutions, and a Bundle of Confusion: What is a Discounter to do? In: Antitrust, Summer 2010, Volume 24, Number 3, p. 46.

JONES, Alison; SUFFRIN, Brenda. EC Competition Law - Text, Cases and Materials, Oxford University Press, 2001.

KALLAUGHER, John; SHER, Brian. Rebates Revisited. In: European Competition Law Review, 2004, p. 263-285.

KIRKWOOD, John B.; LANDE, Robert H. The Chicago School's Foundation is Flawed: Antitrust Protects Consumers, Not Efficiency. In: PITOFSKY, Robert (Ed.). How the 
Chicago School Overshot the Mark. The Effect of Conservative Economic Analysis of U.S. Antitrust, Oxford University Press, 2008, p. 89-97.

KLEIN, Benjamin; WRIGHT, Joshua. The Economics of Slotting Contracts. Journal of Law and Economics, Vol. 50, No. 3 (August 2007), pp. 421-454.

KOLASKY, William. North Atlantic Competition Policy: Converging towards What? Discurso datado de 17 de maio de 2002, acessível em www.usdoj.gov/atr/public/speeches/speech_kolasky.htm.

KORAH, Valentine; O'SULLIVAN, Denis. Distribution Agreements Under the EC Competition Rules, Hart Publishing Limited, 2002.

KOVACIC, William. The Intelectual DNA of Modern U.S. Competition Law for Dominant Firm Conduct: The Chicago/Harvard Double Helix. In: Columbia Business Law Review, V. 1, 2007, p. 1-80.

KOVACIC, William. Competition Policy in the European Union and the United States: Convergence or Divergence? Artigo apresentado na Bates White Fifth Annual Antitrust Conference, em 2 de junho de 2008, acessível em http://www.ftc.gov/speeches/kovacic/080602bateswhite.pdf.

KOVACIC, William; SHAPIRO, Carl. Antitrust Policy; A Century of Economic and Legal Thinking. In: Journal of Economic Perspectives, V. 14, no. 1, Winter 2000, p. 43-60.

KRATTENMAKER, Thomas G.; LANDE, Robert H.; SALOP, Steven C. Monopoly Power and Market Power in Antitrust law. In: The Georgetown Law Journal, 1987, v. 76, p. 241-269.

KRATTENMAKER, Thomas G.; SALOP, Steven C. Anticompetitive Exclusion: Raising Rivals Cost to Achieve Power over Price. In: Yale Law Journal, v. 96, 1986, p. 209.

LANDES, William M; POSNER, Richard A. Market Power in Antitrust Cases. In: Harvard Law Review, v. 94, March 1981, n. 5, p. 937-996. 
LEMLEY, Mark A.; LESLIE, Christopher R. Categorical Analysis in Antitrust Jurisprudence. In: John M. Olin Program in Law and Economics, Stanford Law School, Working Paper No. 348, Novembro de 2007, disponível em http://papers.ssrn.com/sol3/papers.cfm?abstract_id=1026967.

MANNE, Geoffrey A.; WRIGHT, Joshua D. Google and the Limits of Antitrust: The Case Against the Case Against Google. In: George Mason University Law and Economics. Research Paper No. 2010-19, disponível em http://papers.ssrn.com/sol3/papers.cfm?abstract_id=1577556, acesso em novembro de 2011.

McGEE, John S. Predatory Price Cutting: The Standard Oil (N.J.) Case. Journal of Law and Economics, Vol. 1 (Oct., 1958), pp. 137-169.

MELAMED, A. Douglas. Exclusive Dealing Agreements and Other Exclusionary Conduct - Are there Unifying Principles? In: Antitrust Law Journal, v. 73, 2005-2006, p. 375412.

MONTI, Giorgio. EC Competition Law. Cambridge University Press, 2007.

MOREIRA, José Carlos Barbosa. A ação popular no direito brasileiro como instrumento de tutela jurisdicional dos chamados interesses difusos. In: Revista de Processo, n. 28.

MOTTA, Massimo. Competition Policy: Theory and Practice. Cambridge University Press, 2004.

MOTTA, Maximo e DE STREEL, Alexandre. Exploitative and Exclusionary Excessive Prices in EU Law. Trabalho apresentado na $8^{\text {th }}$ Annual European Union Competition Workshop, Florença, 2003, p. 1, disponível em http://professorgeradin.blogs.com/professor_geradins_weblog/files/ExcessivePrices 18 122003.pdf, acesso em novembro de 2011.

NUSDEO, Fabio. Verbete "Abuso do Poder Econômico”, Enciclopédia Saraiva do Direito, vol. 2, Ed. Saraiva, p. 121. 
O’DONOGHUE, Robert; PADILLA, A Jorge. Law and Economics of Article 82 EC. Hart Publishing, 2006.

PADILLA, Jorge; SLATER, Donald. Rebates as an Abuse of Dominance under Article 82 EC. In: GCLC Research Papers on Article 82 EC, July 2005, p. 84-104.

PAGE, William H.; LOPATKA, John E. Bargaining and Monopolization: In Search of the "Boundary of Section 2 Liability" Between Aspen and Trinko. In: Antitrust Law Review, v. 73, n.1, 2005, p. 115-152.

PAGE, William H.; LOPATKA, John E. The Microsoft Case: Antitrust, High Technology, and Consumer Welfare. The University of Chicago Press, 2007.

PARDOLESI, Roberto e ARNAUDO, Luca. Single-Firm Conduct: a Discipline in Search of Itself (Try it with Google)? Trabalho desenvolvido a partir de um ensaio escrito por Roberto Pardolesi e publicado em Mercato concorrenza regole, 2009, 475, com o nome de Condotta unilaterale d'impresa: uma disciplina in cerca d'identità. Disponível em http://papers.ssrn.com/sol3/papers.cfm?abstract_id=1541928, acesso em novembro de 2011.

PITOFSKY, Robert. The Political Content of Antitrust. In: University of Pennsylvania Law Review, v. 127, n. 4, April 1979, pp. 1051-1075.

POSNER, Richard A.. The Chicago School of Antitrust Analysis. In: University of Pennsylvannia Law Review, v. 127, 1978-1979, p. 925-948.

POSNER, Richard. Antitrust Law, 2 ed., 2001.

RAGAZZO, Carlos Emmanuel Joppert. Preço Abusivo, Eficácia Jurídica e Análise Econômica. Revista do IBRAC, Direito da Concorrência, Consumo e Comércio Internacional, Ano 18, Vol. 19, jan-jun-2011.

RAGAZZO, Carlos Emmanuel Joppert; SILVA, Rutelly Marques. "Viaje por $R \$ 50,00 ”:$ Promoção ou Preço Predatório?, janeiro de 2008, disponível em http://works.bepress.com/carlos_ragazzo/10, acesso em novembro de 2011. 
RÖLLER, Lars-Hendrick; STEHMANN, Oliver. The Year 2005 at DG Competition: The Trend Towards a More Effects-Based Approach. In Review of Industrial Organization, v. 29, 2005.

SALOMÃO FILHO, Calixto.Direito Concorrencial - As Condutas. São Paulo: Malheiros Editores, 2003.

SALOMÃO FILHO, Calixto. Recusa da contratar: disciplina jurídica. In: Regulação e Concorrência: estudos e pareceres, São Paulo, Malheiros, 2002, p. 137-150.

SALOMÃO FILHO, Calixto. Direito Concorrencial - As Estruturas. São Paulo: Malheiros Editores, 1998.

SALOP, Steven C. Economic Analysis of Exclusionary Vertical Conduct: Where Chicago has Overshot the Mark. In: PITOFSKY, Robert (Ed.). How the Chicago School Overshot the Mark. The Effect of Conservative Economic Analysis of U.S. Antitrust, Oxford University Press, 2008, p. 141-155.

SALOP, Steven C. Exclusionary Conduct, Effect on Consumers, and the Flawed ProfitSacrifice Standard. In: Antitrust Law Journal, v. 73, n. 2, 2006.

SAMPAIO, Patrícia Regina Pinheiro. Direito da Concorrência e Obrigações de Contratar, Rio de Janeiro, Editora Elsevier, 2009.

SHIEBER, Benjamim. Abusos do Poder Econômico. Direito e experiência antitruste no Brasil e nos EE.UU. São Paulo: Editora Revista dos Tribunais, 1966.

SCHUARTZ, Luis Fernando. A desconstitucionalização do direito de defesa da concorrência. In: Revista do IBRAC, São Paulo, v. 16, n.1, 2009, p. 325-351.

SOCIEDADE BRASILEIRA DE DIREITO PÚBLICO (SBDP). Revisão judicial das decisões do Conselho Administrativo de Defesa Econômica: pesquisa empírica sobre os casos julgados pelos Tribunais Regionais Federais (TRFs), Superior Tribunal de Justiça (STJ) e Supremo Tribunal Federal (STF). Belo Horizonte: Fórum, 2011. 
SPECTOR, David. Loyalty Rebates: An Assessment of Competition Concerns and a Proposed Structured Rule of Reason. In: Competition Policy International, v. 1, n. 2, Autumn 2005.

STEINER, Robert. Category Management: A Pervasive, New Vertical/Horizontal Format. In: Antitrust. Spring 2001.

STEUER, Richard. Bundling Beyond Borders. In: Antitrust, Summer 2010, Volume 24,, Number 3, p. 40-45.

STEUER, Richard M. Bundles of Joy. In: Antitrust, v. 22, n. 2, Spring 2008.

STEUER, Richard. Discounts and Exclusive Dealing. In: Antitrust Magazine, v. 7, Spring 1993.

SUlliVAN, Thomas; HOVENKAMP, Herbert. Antitrust Law, Policy and Procedure: Cases, Materials, Problems. $4^{\text {th }}$ Edition, LexisNexis, 1999.

TAVARES GUERREIRO, José Alexandre. Formas de Abuso de Poder Econômico. In: Revista de Direito Mercantil, Industrial, Econômico e Financeiro, Ano XXVI (nova série), n. 66, abril-junho de 1987, Editora Revista dos Tribunais, p. 41-52.

TEMPLE LANG, John; O'DONOGHUE, Robert. The Concept of an Exclusionary Abuse under Article 82 EC. In: GCLC Research Papers on Article 82 EC, 2005, p. 38-64.

TEMPLE LANG, John; O’DONOGHUE, Robert. Defining Legitimate Competition: How to Clarify Pricing Abuses under Article 82 EC. In: Fordham International Law Journal, v. 26, 2002-2003, p. 83-162.

TOM, Williard K; BALTO, David A.; AVERITT, Neil W. Anticompetitive Aspects of Market Share-Discounts and Other Incentives to Exclusive Dealing. In: Antitrust Law Journal, v. 67, 2000.

TORRE-SCHAUB, Marthe. Essai Sur La Construction Juridique de La Categorie de Marché. Paris, LGDJ, 2002. 
VAN BAEL, Ivo V.; BELLIS, Jean-François. Competition Law of the European Community. $4^{\text {th }}$ Edition, Kluwer Law International, 2005.

VAN DEN BERGH, Roger. The difficult reception of economic analysis in European Competition Law, In: CUCINOTTA, Antonio; PARDOLESI, Roberto; VAN DEN BERGH, Roger (eds.) Post-Chicago Developments in Antitrust Law. New Horizons in Law and Economics Series, Edward Elgar, 2002.

VAZ, Isabel. Direito Econômico da Concorrência. Rio de Janeiro: Forense, 1993.

VAZ, Isabel. As três vertentes do direito da concorrência. In: Revista de Direito Econômico, Conselho Administrativo de Defesa Econômica-CADE, v. 27, janeiro/julho de 1998, p. $35-47$.

VICKERS, John. Market Power in Competition Cases. In: European Competition Journal, July 2006, p. 3-14.

VICKERS, John. Abuse of Market Power. In: Economic Journal, v. 115, n. 504, June 2005, p. 244-261.

WERDEN, Gregory J. Identifying Exclusionary Conduct Under Section 2: The "No Economic Sense” Test. In: Antitrust Law Journal, v. 73, n. 2, 2006, p. 413-433.

WHINSTON, Michael D. Lectures on Antitrust Economics. The Cairoli Lectures, 2006.

WHISH, Richard. Competition Law. 6th Edition, LexisNexis Buttersworths, 2008.

WHISH, Richard. Competition Law. 5th Edition, LexisNexis Buttersworths, 2005.

WRIGHT, Joshua. Slotting Contracts and Consumer Welfare. In: Antitrust Law Journal, v. 74, 2007.

WRIGHT, Joshua D. Antitrust Law and Competition for Distribution. In: Yale Journal on Regulation, v. 23, n. 2, Summer 2006. 